\author{
SZEGEDI TUDOMÁNYEGYETEM \\ TERMÉSZEETUDOMÁNYI ÉS INFORMATIKAI KAR \\ MIKROBIOLÓGIAI TANSZÉK \\ BIOLÓGIA DOKTORI PROGRAM
}

\title{
HIGH MOBILITY GROUP FEHÉRJÉK ÉLETTANI SZEREPÉNEK VIZSGÁLATA ASPERGILLUS NIDULANS MODELLSZERVEZETBEN
}

DOKTORI (Ph.D.) ÉRTEKEZÉS

KÉSZÍTETTE: KARÁCSONY ZOLTÁN

TÉMAVEZETŐ: Dr. HAMARI ZSUZSANNA 


\section{TARTALOMJEGYZÉK}

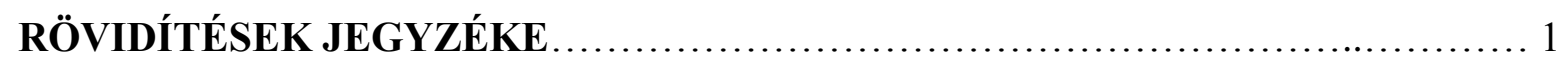

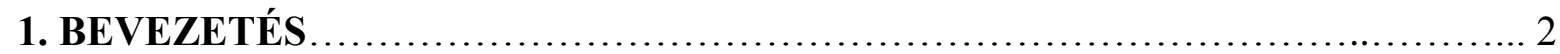

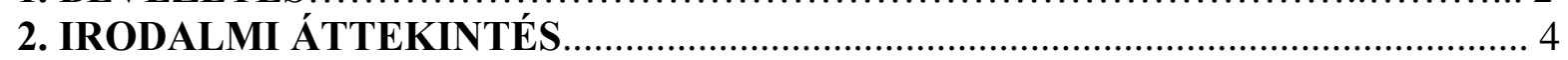

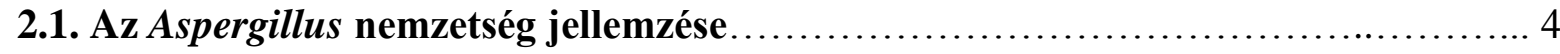

2.2. Az Aspergillus nidulans ivaros és ivartalan életciklusa ......................... 5

2.3. Oxidatív stressz, reaktív oxigéngyökök közömbösítése $A$. nidulans-ban............ 8

2.4. A „High Mobility Group-box" fehérjék jellemzése............................. 9

2.5. A kromatinkapcsolt architektúrális HMG-box fehérjék jellemzése.............. 10

2.5.1. A S. cerevisiae modellszervezetben azonositott, architektúrális szerepet betöltö

kromatinkapcsolt HMG-box fehérjék........................................... 10

2.5.1.1. A Hmo1p és a Hmo2p....................................................... 10

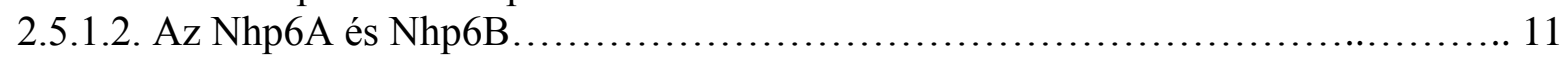

2.5.1.3. Az Abf2p............................................................... 11

2.5.2. A nukleoidszervezö mitokondriális $H M G$-box fehérjék áttekintése .................. 12

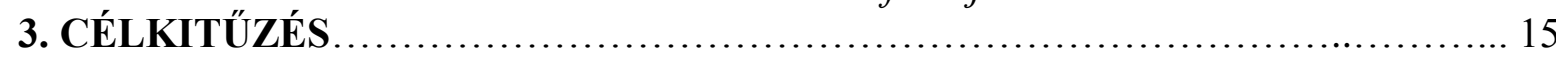

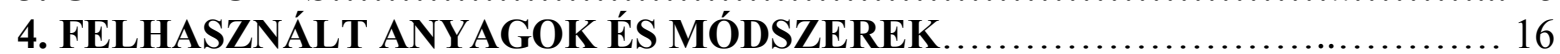

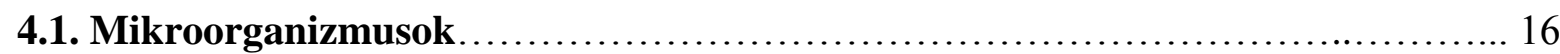

4.1.1. I. táblázat: A. nidulans törzsek............................................ 16

4.1.2. Escherichia coli törzs......................................................... 19

4.2. Tenyésztési körülmények................................................... 19

4.2.1. A. nidulans tenyésztésére felhasznált táptalajok .................................... 19

4.2.2. Az A. nidulans tenyésztési körülményei...................................... 20

4.2.3. A csírázó és nem csírázó konídiumok elkülönitése a hmbBA törzs esetében............ 21

4.2.4. E.coli tenyésztéséhez felhasznált táptalajok................................... 21

4.3. II. táblázat: Felhasznált vektorok............................................ 21

4.4. III. táblázat: Felhasznált indítószekvenciák................................... 21

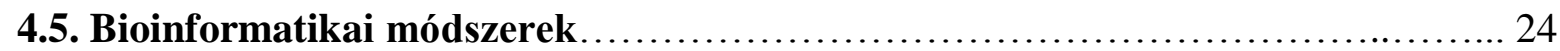

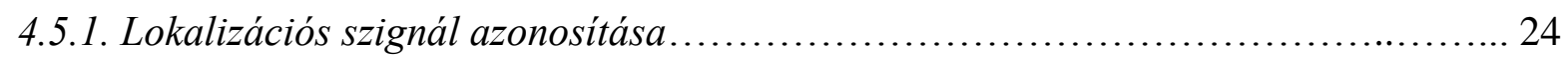

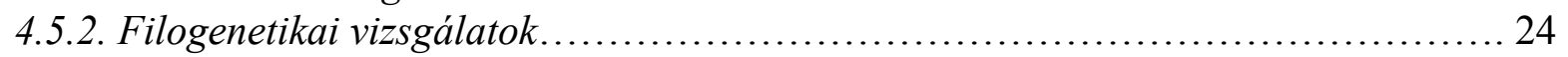

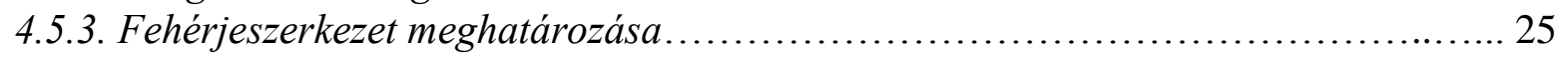

4.6. Nukleinsav-manipulációhoz felhasznált módszerek......................... 25

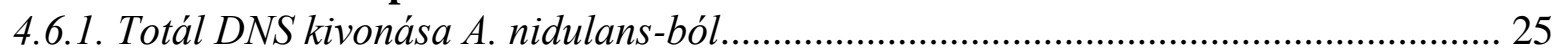

4.6.2. RNS kivonása A. nidulans-ból, cDNS szintézise .............................. 26

4.6.3. Plazmid minipreparátumok készitése E. coli-ból................................ 26

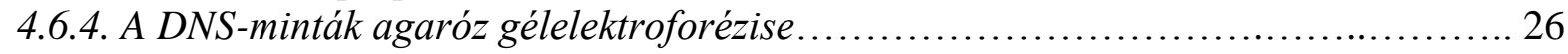

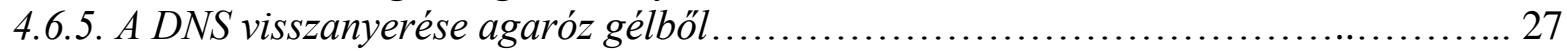

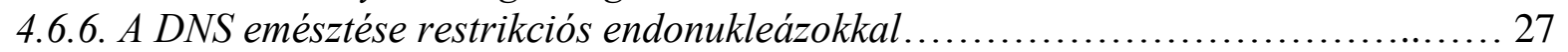

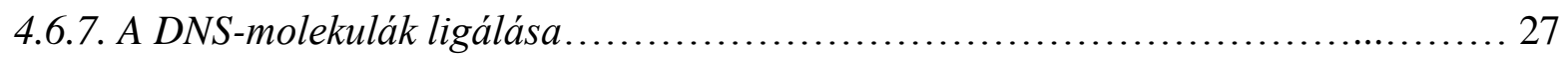

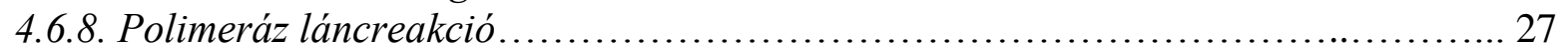

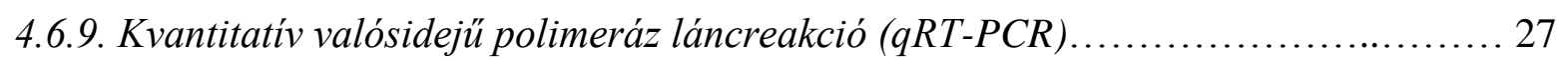

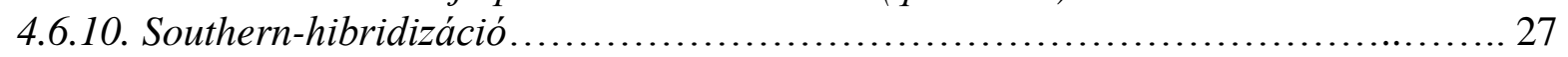

4.7. Kompetens $E$. coli sejtek transzformálása ..................................... 28

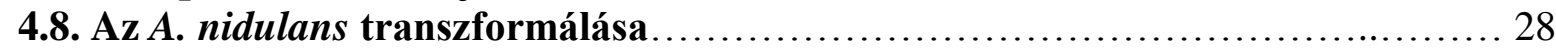

4.9. A szubsztitúciós kazetták létrehozása $h m b A, h m b B$ és $h m b C$ deléciójához......... 29

4.10. A $\mathbf{h m b B}$ fúziós konstrukciók előállítása ..................................... 31

4.10.1. A hmbB-gfp-t (C-terminális GFP-fúziós fehérjét) kódoló konstrukció

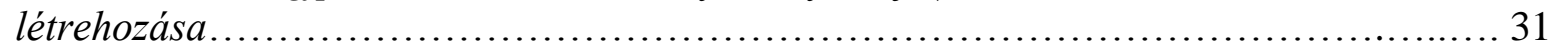


4.10.2. A gfp-hmbB-t (N-terminális GFP-fúziós fehérjét) kódoló konstrukció

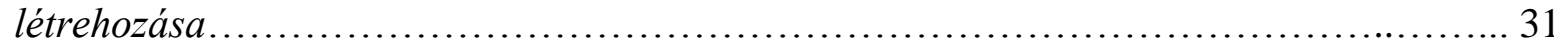

4.10.3. A HmbB-His-Tag fúziós fehérjét kódoló konstrukció létrehozása .................. 32

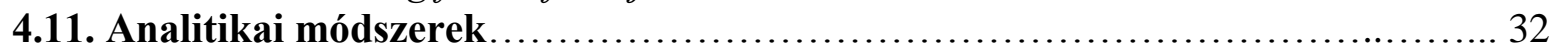

4.11.1. A konídiumok cukor- és polialkohol-tartalmának GC-MS analízise................. 32

4.11.2. A Sterigmatocisztin vékonyréteg-kromatográfiás vizsgálata ...................... 33

4.11.3. A trehalóz vékonyréteg-kromatográfiás vizsgálata .............................. 33

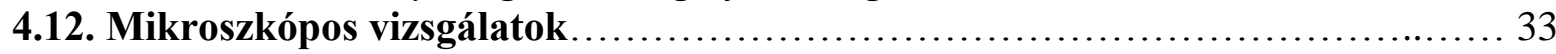

4.13. Redox enzimek aktivitásának mérése ....................................... 34

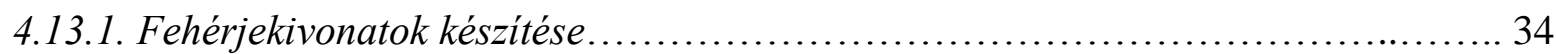

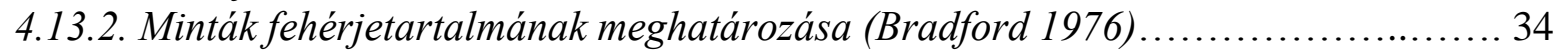

4.13.3. Glutation-reduktáz (GR) mérése (Pinto és mtsai. 1984)........................... 35

4.13.4. Glutation peroxidáz (GPx) mérése (Chiu és mtsai. 1976).......................... 35

4.13.5. Glutation-S-transzferáz (GST) mérése (Warholm és mtsai. 1985)................... 35

4.13.6. Glükóz-6-foszfát dehidrogenáz (G6PD) mérése (Emri és mtsai. 1994).............. 36

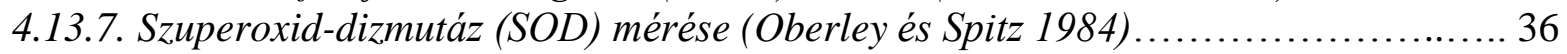

4.13.8. Kataláz (CAT) mérése (Roggenkamp mtsai. 1974) ............................. 37

4.14. Reaktív oxigéngyökök (ROS) és a semlegesítésükben résztvevő metabolitok (oxidált és redukált glutation, NADP és NADPH, összes tiol) mérése.................. 37

4.14.1. Szuperoxid szabadgyökök mérése (Carter és mtsai. 1994)......................... 37

4.14.2. Diklorofluoreszcein-diacetát (DCFDA)-oxidáló kapacitás mérése (Ezaki és mtsai.

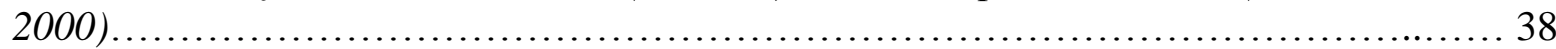

4.14.3. Redukált és oxidált glutation (GSH és GSSG) mérése (Anderson 1995)............. 38

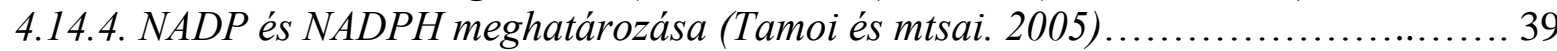

4.14.5. Összes tiol mennyiségének meghatározása (Lewinska és Bartosz 2008).............. 39

4.15. Western blot analízis.................................................... 40

4.16. Konídiumok és micéliumból származó protoplasztok oxigénfelvételének

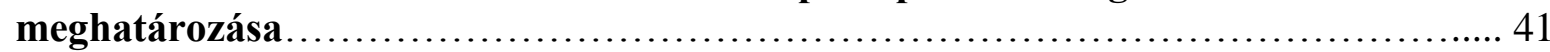

4.17. Az A. nidulans homo- és heterozigóta keresztezése.......................... 41

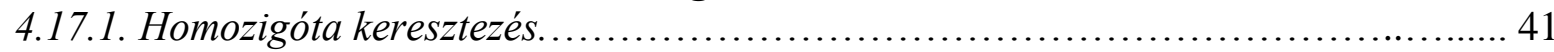

4.17.2. Heterozigóta keresztezés............................................... 42

4.18. A spórák kolóniaképző képességének vizsgálata............................ 42

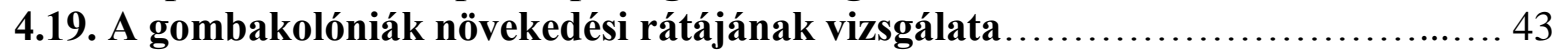

4.20. Statisztikai analízishez felhasznált módszerek............................. 43

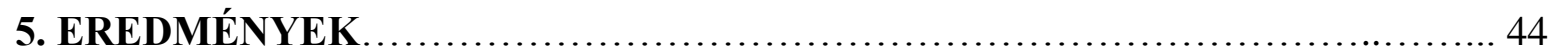

5.1. HMG-box fehérjék $A$. nidulans -ban........................................ 44

5.1.1. Kromatinkapcsolt HMG-box fehérjék azonositása A. nidulans-ban................. 44

5.1.2. HmbA...................................................................... 45

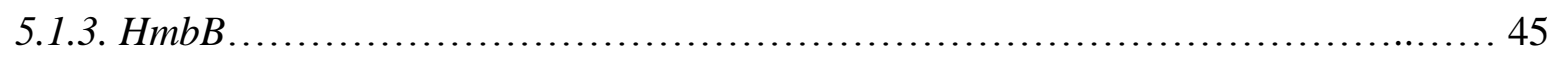

5.1.3.1. A HmbB feltételezhető mitokondriális lokalizációja, doménszerkezete és összehasonlítása más mitokondriális HMG-box fehérjékkel......................... 45

5.1.3.2. A HmbB filogenetikai analízise............................................... 47

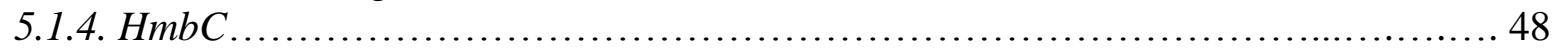

5.2. A HmbA vizsgálata......................................................... 49

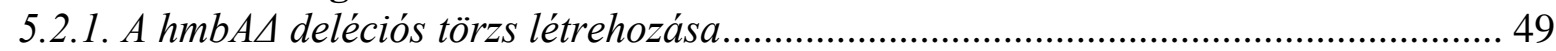

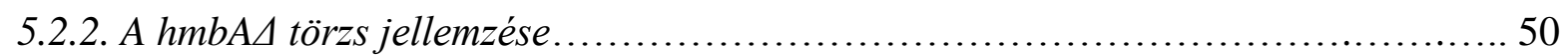

5.2.2.1. A $h m b A \Delta$ törzs alacsony növekedési rátája................................ 50

5.2.2.2. A HmbA hiányában megváltozik az alacsony $\mathrm{pH}$-értékhez történő adaptáció........ 50

5.2.2.3. A HmbA szerepe a másodlagos metabolitok szintézisében....................... 51

5.2.2.4. A HmbA szerepe a trehalóz bioszintézisében................................. 52 


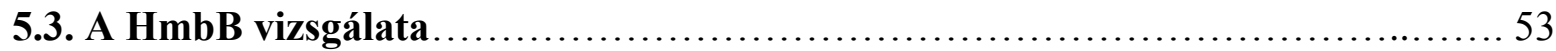

5.3.1. A hmbB gén kifejezödése csírázó konídiumokban és gombafonalakban................ 53

5.3.3. A hmbBA deléciós törzs és a fúziós konstrukciókat (hmbB-gfp, gfp-hmbB és hmbB-his-

tag) kifejezö törzsek létrehozása ................................................. 53

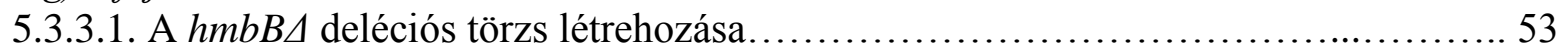

5.3.3.2. A $h m b B$-gfp fúziós konstrukciót kifejező törzs létrehozása...................... 54

5.3.3.3. A $g f p-h m b B$ fúziós konstrukciót kifejező törzs létrehozása...................... 55

5.3.3.4. A HmbB-His-Tag fúziós fehérjét kifejező törzs létrehozása...................... 55

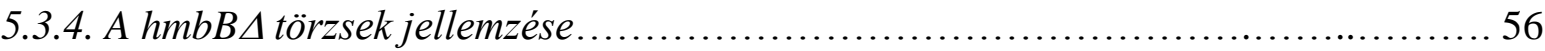

5.3.4.1. Sejtmorfológia-rendellenességek az elsődleges hifákban....................... 56

5.3.4.2. Növekedési tesztek - oxidatív stresszorokkal szemben mutatott eltérő

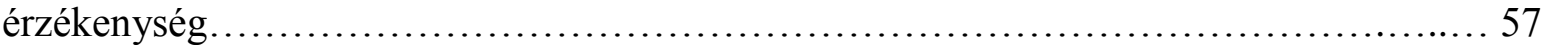

5.3.4.3. A $h m b B \Delta$ törzs oxidatív stresszel szemben mutatott toleranciájának részletes

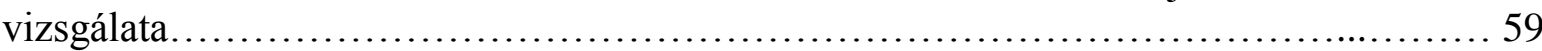

5.3.4.4. Aszkospóra- és konídiospóra-termelésben, a spórák csírázóképességében tapasztalt

rendellenességek, és azok lehetséges okainak vizsgálata............................... 60

5.3.4.5. A nem csírázó hmbB $\Delta$ konídiumfrakció metabolikusan aktív konídiospórákat

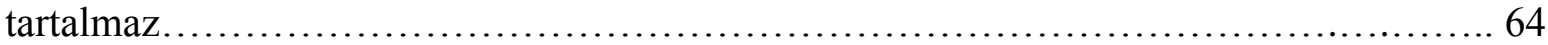

5.3.4.6. A $h m b B \Delta$ konídiumok cukor- és polialkohol-spektrumának eltérése a nyugalmi spóra

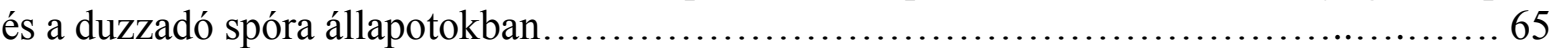

5.3.4.7. A micélium sterigmatocisztin-termelésében tapasztalt eltérések.................... 65

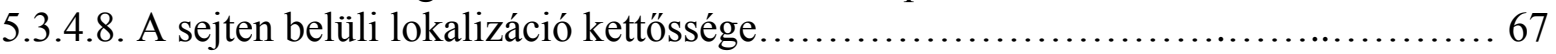

5.3.4.9. A mtDNS-kópiaszámban és mitokondriális transzkripcióban tapasztalt

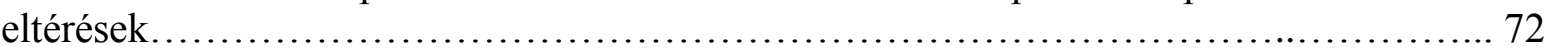

5.3.4.10. A HmbB fehérje redox folyamatokra gyakorolt hatásának részletes

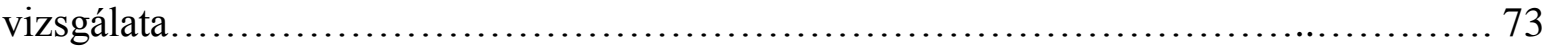

5.3.4.10.1. A $h m b B$ deléció hatása a redox állapotra izotropikus növekedésben lévő

konídiumokban és micéliumban............................................... 74

5.3.4.10.2. A menadion és diamid hatása a $h m b B \Delta$ micéliumok redox állapotára............ 75

5.3.4.10.4. A $h m b B \Delta$ törzs oxigénfelvétele a vad típushoz hasonló értéket mutat............ 80

5.4. A HmbC vizsgálata ............................................................. 80

5.4.1. A hmbCA deléciós törzs létrehozása ............................................. 80

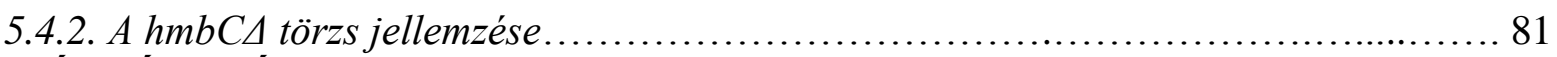

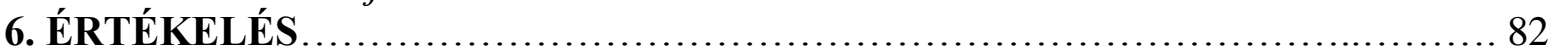

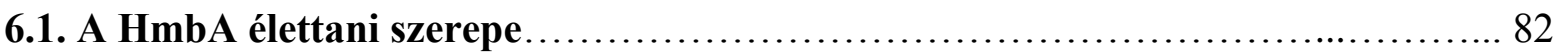

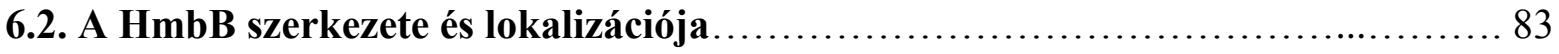

6.3. A HmbB szerepe a sterigmatocisztin bioszintézisében........................ 85

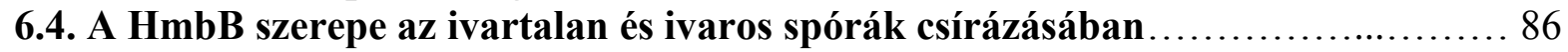

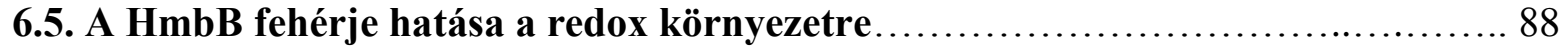

6.6. A HmbB funkcióinak összefoglalása ....................................... 92

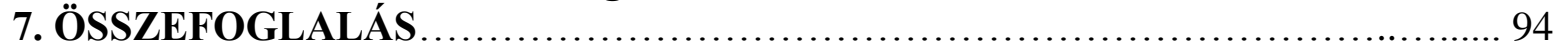

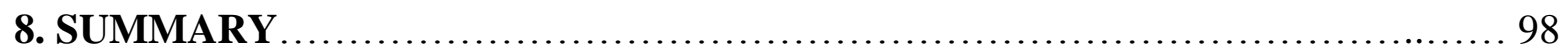

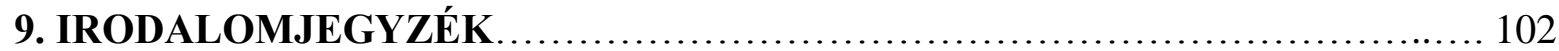

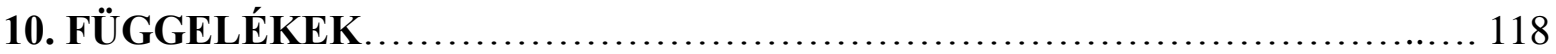




\section{RÖVIDÍTÉSEK JEGYZÉKE}

ATP: adenozin-trifoszfát

BSA: borjú vérsavó

CAT: kataláz

CDNB: 1-klór-2,4-dinitrobenzol

CHP: kümén-hidroperoxid

CM: komplett táptalaj

DAPI: 4',6-diamidino-2-fenilindol

DCFDA: diklorofluoreszcein-diacetát

DHE: dihidroetídium

DMSO: dimetil-szulfoxid

DNS: dezoxiribonukleinsav

DTNB: 5,5-ditiobis-nitrobenzoesav

EDTA: etilén-diamin-tetraecetsav

EtBr: etídium-bromid

G6PD: glükóz-6-foszfát-dehidrogenáz

GC-MS: gázkromatográf-

tömegspektrométer

GFP: zöld fluoreszcens fehérje

GPx: glutation-peroxidáz

GR: glutation-reduktáz

GSH: redukált glutation

GSSG: oxidált glutation

GST: glutation-S-transzferáz

GTP: guanozin-trifoszfát

HEPES: hidroxietilpiperazin-etanoszulfonát

HMG: High Mobility Group

mtDNS: mitokondriális RNS

LB: Luria-Bertani táptalaj
LETS: $\mathrm{LiCl}+\mathrm{EDTA}+$ Tris +SDS

MM: minimál táptalaj

mRNS: hírvivő RNS

MTT: 3-(4,5-dimetiltiazol-2-il)-2,5-

difeniltetrazólium bromid

NADP: nikotinamid-adenin-dinukleotidfoszfát, oxidált

NADPH: nikotinamid-adenin-dinukleotidfoszfát, redukált

NBT: nitro-blue tetrazólium

Paba: para-amino-benzoesav

PCI: fenol-kloroform-izoamil-alkohol

PCR: polimeráz láncreakció

PEG: polietilén-glikol

PMS: fenazin-metoszulfát

PMSF: fenil-metil-szulfonil-fluorid

PVDF: polivinilidén-fluorid

RT-PCR: valósidejü polimeráz láncreakció

RFP: vörös fluoreszcens protein

RNS: ribonukleinsav

ROS: reaktív oxigéngyökök

SDS: nátrium-lauril-szulfát

SM: szacharózos minimál táptalaj

SOD: szuperoxid-dizmutáz

TAE: Tris+ecetsav+ EDTA

TBST: Tris $+\mathrm{NaCl}+$ Tween 20

TCA: triklór-ecetsav

TLC: vékonyréteg-kromatográfia

Tris: Trisz(hidroximetil)-aminometán 


\section{BEVEZETÉS}

Az Aspergillus nidulans az egyik legjobban tanulmányozott fonalasgomba modellszervezet. Ivaros, ivartalan és paraszexuális életciklussal is rendelkező mikroorganizmus, genomja haploid, ezért esetében könnyen alkalmazhatók mind a klasszikus, mind pedig a reverz genetikai módszerek. A faj teljes genomszekvenciája ismert (Galagan 2005). A faj genetikai módosítása több évtizedes múltra tekint vissza. Számos mutáns törzset hoztak létre véletlenszerü mutagenezissel, valamint a faj célzott genetikai manipulációja is régóta megoldott (Tilburn és mtsai. 1983).

Számos biológiai folyamatot tanulmányoztak az A. nidulans modellszervezeten, mint pl. az életciklusát és annak szabályozását, a vegetatív és szexuális reprodukciót, a mitokondriális genomszerveződést és intronmobilitást, az organellumokhoz kötött intracelluláris folyamatokat, a membrántranszport-folyamatokat, a különböző környezeti hatások által kiváltott stresszfolyamatokata az észleléstől a végső stresszválasz kialakulásáig, az apoptózist, a fehérjeevolúciót, a kromatinfunkciót, a metabolikus útvonalakat és azok regulációját. Ez utóbbi területen különösen fontosak az ipari illetve humán egészségügyi szempontból jelentős másodlagos metabolit-termelési útvonalak, és az azok regulációjának feltárására irányuló kutatások.

A High Mobility Group fehérjék a kromatinon ható, nem hiszton-típusú fehérjék közé tartoznak. Ez a fehérjecsalád az utóbbi évtizedekben intenzív kutatások tárgyát képezi. Széleskörű szerepük bizonyosodott be számos élettani folyamatban alacsonyrendü eukariótákkal végzett kísérletek eredményeként, emellett az emberben is fontos funkciókat töltenek be pl. a veleszületett immunitás és tumorok kialakításában, így egészségügyi vonatkozásuk is jelentős (Lee mtsai. 2014, Pallante és mtsai. 2015). Egyre több kutatás foglalkozik az A. nidulans kromatinszerveződésének és kromatinmüködésének tanulmányozásával, amely során vizsgálták a nukleoszómák pozícionálódását promóter régiókban (García és mtsai. 2008), valamint a hiszton acetil-transzferázok, hiszton metiltranszferázok és -demetilázok, a kromatin-remodelling komplexek, a heterokromatin protein 1 és a H1 hiszton kromatinszerveződésben és müködésben betöltött szerepét (Ramón és mtsai. 2000, Reyes-Dominguez és mtsai. 2010). A kromatinkapcsolt, nem hiszton-típusú High Mobility Group fehérjék tanulmányozása azonban meglehetősen háttérbe szorult, és napjainkig egyetlen architekturális High Mobility Group fehérjét sem azonosítottak és jellemeztek A. nidulans-ban annak ellenére, hogy az élesztő modellszervezet Saccharomyces cerevisiae és Candida albicans fajokban évtizedekkel ezelött elkezdődött a vizsgálatuk, 
amely jelenleg is tart. Munkánk célja az A. nidulans architekturális High Mobility Group fehérjéinek azonosítása és élettani funkciújuk vizsgálata volt, ezzel kibővítve az egyéb tekintetben igen jól jellemzett gombafajjal és a HMG fehérjék müködésével kapcsolatos ismereteket. 


\section{IRODALMI ÁTTEKINTÉS}

\subsection{Az Aspergillus nemzetség jellemzése}

Az Aspergillus nidulans az Aspergillus gombanemzetség tagja. A nemzetség rendszertanilag az Ascomycota törzs Eurotiomycetes osztályának Eurotiales rendjében a Trichocomaceae családba sorolható. Az Aspergillus nemzetség mind fajszámát (több mint 200), mind elterjedtségét tekintve jelentős gombacsoport. Képviselői előfordulnak a talajban, bomló biomasszán, épületek belterében, élelmiszernövényeken szántóföldi illetve kártevőként és esetenként fertőzéseket is okozhatnak (Gugnani 2003).

Az Aspergillusok között számos faj ipari jelentőséggel rendelkezik. Az A. oryzae, A. sojae és A. tamarii fajokat évezredek óta használják tradícionális fermentált élelmiszerek előállítására (Gugnani 2003). Több fajukat a modern iparban is használják, közülük a legjelentősebb az A. niger, A. oryzae és az A. terreus. Az élelmiszeriparban enzimek (pl. amiláz, glükóz-oxidáz, kataláz, lipáz, xilanáz) (Fleißner és Dersch 2010), valamint elsődleges metabolitok (pl. citromsav, glükonsav) termeltetésére használják őket. Gyógyászati szempontból fontos az A. terreus által termelt másodlagos metabolit, a lovasztatin előállítása, amelyet szív- és érrendszeri betegségek megelőzésére használnak (Ward és mtsai. 2005, Jaivel és Marimuthu 2010).

Az Aspergillus-ok között találunk növénypatogéneket, de leginkább szántóföldi és raktári kártevőként tartják őket számon. Különösen komoly élelmiszer-egészségügyi kockázatot jelentenek az Aspergillus fajok által termelt mikotoxinok. Karcinogén hatású mikotoxinjaik az aflatoxinok (A. flavus, A. parasiticus) és a sterigmatocisztin (A. nidulans, A. versicolor), valamint a vesekárosító hatásukról ismert ochratoxinok (A. ochraceus, $A$. niger, A. carbonarius) (Cotty és Bathnagar 1994, Kelkar és mtsai. 1997, Gugnani 2003). Napjainkra a mikotoxinok analitikai módszerekkel történő kimutatása rutinszerüvé vált, és az egyre szélesebb körü vizsgálatok eredményeként elmondható, hogy az emberi és állati élelmezésben felhasznált alapanyagok és mikotoxinokkal való szennyezettsége jelentős probléma (Marin és mtsai. 2013). A helyzetet rosszabbítja, hogy a toxinszennyezettség mértéke a klímaváltozással párhuzamosan várhatóan fokozódó tendenciát fog mutatni a termelő gombatörzsek elterjedési területének változása miatt (Russell és mtsai. 2010).

$\mathrm{Az}$ Aspergillus nemzetségben opportunista humánpatogén fajok is találhatóak, melyek évről évre egyre több megbetegedést okoznak. A leggyakoribb kórokozó az $A$. fumigatus, de jelentősek még az A. flavus és A. niger fajok is. A szem és a fül fertőzése mellett súlyos légzőszervi kórképeket is kiválthatnak, mint például allergiás 
bronchopulmonális aszpergillózis, aszpergillóma, illetve invazív aszpergillózis. Az Aspergillus fertőzések növekvő száma összefüggésbe hozható a kemoterápiás és immunszupresszív kezelések egyre kiterjedtebb használatával (Gugnani 2003).

Az A. nidulans a nemzetségbe tartozó, kísérleti modellorganizmusként nagy jelentőséggel bíró faj, melynek segítségével számos élettani folyamatot sikerült nagy részletességgel felderíteni. A következő fejezetekben (2.2. és 2.3.) részletes bemutatásra kerülnek az általunk vizsgált HMG-box fehérjék által érintett fontosabb élettani folyamatok.

\subsection{Az Aspergillus nidulans ivaros és ivartalan életciklusa}

Az A. nidulans rendelkezik aszexuális és szexuális életciklussal is. Az aszexuális életciklus során a gomba vegetatív növekedési és reprodukciós (konidiogenezis) folyamatokon esik át. A vegetatív növekedés az aszexuális, vagy szexuális úton létrejött spórák csírázásával kezdődik. Az aszexuális konídiospórák csírázásának első fázisa az izotropikus növekedés, melynek során a spórák megduzzadnak, átméröjük megnövekszik. Ennek oka, hogy a spórafal a kitinázok és a glükanázok hatására fellazul, valamint a spóra trehalóztartalma glicerinné alakul át, mely erős ozmotikus hatásánál fogva a konídiumok vízfelvételéhez vezet. A duzzadással egyidőben számos metabolikus átalakulási folyamat következik be, a mitokondriális légzés megélénkül, és számos növekedésben és fejlődésben érintett gén kifejeződik. A duzzadást követően csíratömlő-képződés figyelhető meg, amelyet a sejtmag osztódása kísér. Ennek a fejlődési fázisnak az elindításához a mitokondriális légzésfokozódás eredményeképpen létrejövő reaktív oxigén gyökök, mint szignálmolekulák elengedhetetlenül szükségesek (Lara-Ortiz 2003, Cano-Dominguez 2008), de ugyanakkor jelenlétüket az intracelluláris térben korlátozni is kell, amely a protektív szerepet betöltő molekulák és enzimek aktivitásán alapul (Gille and Sigler 1995). A csíratömlő növekedésével kialakul az elsődleges hifa, melynek elongációjával és elágazásával a gomba átlép a micéliális növekedési fázisba. Külső indukció (pl. ozmotikus stressz, szénéhezés) hatására a vegetatív hifa néhány sejtje megáll a növekedésben és belép az ivartalan életciklus reprodukciós szakaszába, melynek során egyes hifasejtek differenciálódáson esnek át (lábsejtek), és ivartalan szaporítóképletet (konídium) képeznek. A vastag falú lábsejtből aeriális hifa emelkedik ki, amely a konídium nyél részét formálja meg (1./A ábra). A nyél csúcsán egy gömb alakú vezikulum képződik (1./B ábra), amelyről sarjadzással utódsejtek képződnek, és az elsődleges sterigmataréteget, a metulákat képezik (1./B ábra). A metulákról egy osztódást követően fialidok (1./D) füződnek le (másodlagos sterigmataréteg), 
amelyek vagy közvetlenül képzik a 8-8 konídiospórát, vagy egy további lefüződéssel a fialidok második sorát hozzák létre, amelyekről majd a konídiospórák képződnek.
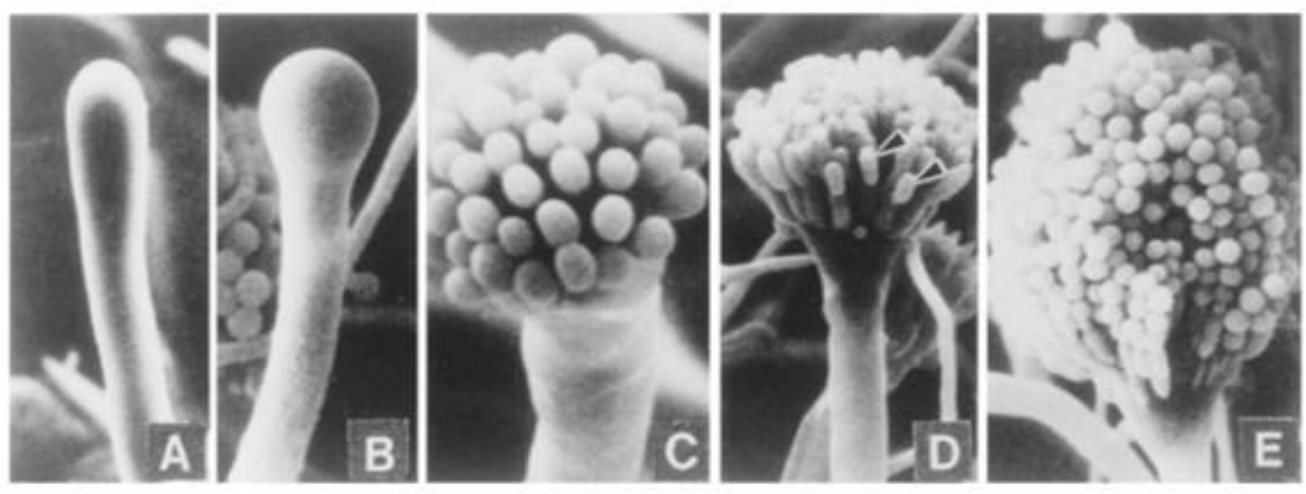

1. ábra: A konídium részeinek kialakulása pásztázó elektronmikroszkópos felvételeken. A: nyél, B: vezikula, C: metulák, D: fialidok, E: konídiospórák (Adams és mtsai. 1998)

Az A. nidulans szexuális reprodukcióját tekintve homotallikus faj. Minden izolátumában megtalálható az ivaros szaporodás iniciációjáért felelős két faktor: a mat $B$ gén által kódolt $\alpha$-box fehérje és a matA gén által kódolt HMG-box fehérje. Az ivaros ciklus kialakulását többféle környezeti tényező is befolyásolja. A szén- és nitrogénforrások bőséges jelenléte, illetve a hypoxia elősegíti, míg bizonyos környezeti stresszfaktorok (erős fény, ozmotikus stressz) gátolják az ivaros ciklus kialakulását (Han 2009). A szexuális ciklus első lépéseként két homokariotikus gombafonal (2/a ábra) heterokariotikus hifává fúzionál (2/b ábra). Az első morfológiai változás a Hülle-sejtek megjelenése (2/c ábra). Ez a kerekded, vastagfalú sejttípus nem képezi részét a kialukuló zárt termőtestnek, csak védelmi funkciót lát el. A Hülle-sejtek gyürüjében jön létre a fiatal termőtest (primordium) ( $2 / \mathrm{d}$ ábra), amelyből kifejlődik az érett termőtest (kleisztotécium) (2/e ábra). A termőtestben az aszkogén hifák horognak (,,crozier”) (2/f ábra) nevezett, dikariotikus struktúrákat képeznek, amelyben megtörténik a sejtmagok fúziója (2/g ábra). A diploid sejtmag meiotikus (2/h ábra), majd mitotikus (2/i ábra) osztódáson esik át. A sejtből rendezetlen tömlő (aszkusz) alakul ki, melyben az ivaros spórák (aszkospórák) képződnek (2/j ábra). 

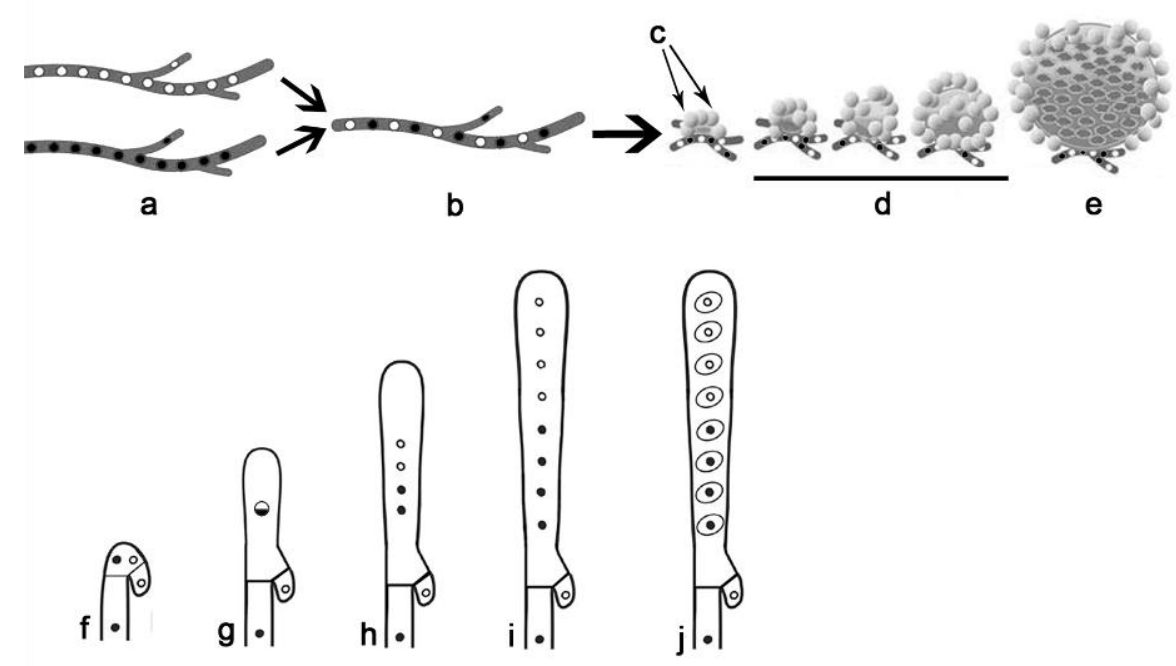

2. ábra: Az ivaros termőtest és az ivaros spórák képződésének folyamata A. nidulansban. a: Homokariotikus hifák, b: Heterokariotikus hifa, c: Hülle-sejtek, d: Primordium, e: Kleisztotécium, f: Hurok (,crozier”), g: Sejtmagok fúziója, h: Meiózis, i: Mitózis, j: Aszkusz érett spórákkal

Az ivaros és ivartalan szaporodási ciklus, valamint a másodlagos metabolizmus szabályozása átfedést mutat A. nidulans-ban. Ebben a rendszerben szerepet játszanak a „velvet” fehérjecsaládba tartozó VeA, VelB, VelC és VosA fehérjék, valamint a LaeA fehérje (Bayram és Braus 2012). A szabályozó rendszerben az egyik kulcsszerepet játszó komponens a VeA fehérje. Fény hatására csökken a fehérje mennyisége és transzportja a sejtmagba (Stinnett és mtsai. 2007, Bayram és mtsai. 2008). A veAA deléciós törzsekben azt tapasztalták, hogy mind az ivaros termőtestek, mind a másodlagos metabolitok képződése sérült (Kato és mtsai. 2003). A VeA fehérje a citoplazmában komplexet képez a VelB fehérjével. A sejtmagba transzportálódva kölcsönhatásba kerül a LaeA-val és kialakul egy trimer komplex. A VeA-VelB dimer szükséges a termőtest kialakításához, míg a LaeA a Hülle-sejtek képzéséhez, valamint az ivartalan spóraképzéshez, de ezen kívül a LaeA a másodlagos metabolizmus általános regulátora is (Bok és Keller 2004), amely epigenetikus szabályozáson keresztül látja el funkcióját (Bok és mtsai. 2006). Kimutatták, hogy kifejeződésekor csökken a sterigmatocisztin-bioszintézis génklaszterben a H3 hiszton 9-es pozíciójú lizin oldalláncának metiláltsága (Reyes-Dominguez és mtsai. 2008), amely a fakultatív heterokromatikus régiók aktiválódásának előfeltétele. A LaeA másodlagos metabolizmust szabályozó szerepében feltételezhetőleg szerepet játszik a VeA-VelB komplex-szel történő kölcsönhatása (Bayram és mtsai. 2008, Sarikaya Bayram és mtsai. 2010). A VelB fehérje a VosA fehérjével is alkothat heterodimert. Ez a komplex gátolja az ivartalan szaporítóképletek kialakulását folyadékkultúrában és fény hiányában, valamint 
szükséges a spórák hosszútávú életképességét biztosító trehalóz szintéziséért felelős gének aktivációjához (Bayram és Braus 2012).

\subsection{Oxidatív stressz, reaktív oxigéngyökök közömbösítése $A$. nidulans-ban}

A reaktív oxigéngyökök (ROS) származhatnak a normál aerob intracelluláris folyamatokból, de külső környezeti tényezők (oxidatív stresszágensek) is elöidézhetik képződésüket. Amellett, hogy a ROS-ok folyamatos veszélyt jelentenek a biológiai membránok és fehérjék épségére, fontos biológiai szerepet is betölthetnek, mint szignálmolekulák (Lara-Ortiz 2003, Cano-Dominguez 2008). A ROS-ok semlegesítése összetett védelmi rendszeren keresztül valósul meg, amely protektív molekulákból, mint pl. tiolokból (cisztein, tioredoxin, glutaredoxin és glutation) és közvetett vagy közvetlen védelmi szerepet betöltő enzimekből (katalázok, szuperoxid-dizmutázok, glutation-Stranszferázok, glutation-reduktázok, peroxidázok, glükóz-6-foszfát-dehidrogenázok, tioredoxin-reduktázok, nitroreduktázok, flavohemoproteinek stb.) áll (Gille és Sigler 1995). A sejtek redukált glutation (GSH) tartalma két módon is elősegíti a ROS-ok elleni védekezést: a fehérjék tiol-csopotjait glutationilálhatják, valamint közvetlenül elreagálva a reaktív gyökökkel, oxidált glutationná (GSSG) alakulnak, melyet a glutation-reduktázok alakítanak vissza GSH-vá NADPH felhasználásával. A NADPH legfőbb forrása a pentózfoszfát útvonalban müködő glükóz-6-foszfát dehidrogenázok müködése, amelyek a nikotinamid-adenin-dinukleotid-foszfátot (NADP-t) NADPH-vá redukálják, miközben a glükóz-6-foszfátot 6-foszfo-glükonáttá (6-foszfoglükonsavvá) alakítják át. A GSH oxidációja végbemehet a glutation-peroxidázok által katalizált, hidrogén-peroxiddal történő reakció során is. Szükséges megjegyezni, hogy A. nidulans esetében a peroxidok elleni védekezésben kisebb szerepet játszanak a katalázok a glutation-peroxidázokhoz képest (Pócsi és mtsai. 2005).

A sejtek GSH és GSSG tartalma nem csak az oxidatív stressz elleni védekezésben játszik fontos szerepet, de kulcsfontosságú molekulák tiol-diszulfid átkapcsolásaival („thiol nano-switching") szabályozzák a sejtciklust az osztódástól kezdve a fejlődésen át a programozott sejthalálig (Schafer és Buettner 2001). Pócsi és munkatársai (2005) bizonyították, hogy a kiegyensúlyozatlan GSSG/GSH arány genomszintű transzkripciós változásokat okoz A. nidulans-ban, és leírták azon gének körét, amelyek kifejeződésére kihat a GSSG/GSH arány változása. Ilyenek például az oxidatív stresszválasz (a SAPK/AtfA szabályozó útvonal elemei, a hozzá tartozó célpontgénekkel), a fehérje-bioszintézis (riboszómális fehérjék génjei), a glükolízis és a sterigmatocisztin-bioszintézis génjei. 
Az oxidatív stresszt okozó menadion és diamid-vegyületek biológiai hatásukat különböző folyamatokon keresztül fejtik ki, ezért alkalmasak a ROS-közömbösítő rendszerek vizsgálatára olyan mutánsok esetében, melyek a vad típustól eltérő érzékenységet mutatnak az oxidatív stresszel szemben. A menadion például szuperoxid anion $\left(\mathrm{O}_{2}{ }^{-}\right)$ képződését váltja ki egy redox folyamat által, mely inaktiválja a 4Fe-4S fehérjéket, miközben $\mathrm{OH}^{•}$ gyökök képződnek. Ez utóbbiak semlegesítésében a glutation-S-transzferázok is részt vesznek, közvetlenül befolyásolva a sejt GSH-tartalmát. A diamid egy tiolcsoportokat oxidáló vegyület, mely a GSH-t GSSG-vé oxidálva közvetlenül megváltoztatja az intracelluláris GSSG/GSH redox-egyensúlyt, valamint képes fehérje-glutation konjugátumok kialakulását is előidézni.

\subsection{A „High Mobility Group-box” fehérjék jellemzése}

A „High Mobility Group” (HMG) fehérjék a kromatint alkotó nem hiszton-típusú fehérjék egyik csoportja. Funkciójukat tekintve lehetnek a kromatin szerkezeti építőelemei, szerepet játszhatnak génkifejeződés szabályozásában, replikációban, rekombinációban és "repair" mechanizmusokban. Közös jellemzőjük, hogy erős polárosságuk és viszonylag kis méretük $(<30 \mathrm{kDa})$ következtében különösen nagy mobilitást mutatnak gélelektroforézis során, valamint a legtöbb fehérjével ellentétben szolubilisek 2-5\% triklór-ecetsavban. A funkcionális doménjük szekvenciája alapján a HMG fehérjék további három alcsoportra oszthatóak: HMGA, HMGB és HMGN (Reeves 2010, Stros 2010).

A HMGB alcsoportra jellemző, hogy HMG-box domént hordoznak, ami egy konzervált, körülbelül 75 aminosav hosszúságú, L-alakú struktúrát képez (HMG-box PF00505), ahol három $\alpha$-hélixet hurkok választanak el egymástól (Stott és mtsai. 2006, Rubio-Cosials és mtsai. 2011, Ngo és mtsai. 2011). Számos fehérje hordozhat HMG-box domént, de nem minden HMG-box domént hordozó fehérje tartozik a HMGB kategóriába. A HMG-box révén a fehérjék szekvencia-specifikusan (általában transzkripciós faktorok), vagy nem szekvencia-specifikusan kötődhetnek a DNS-hez (a kromatinban architektúrális szerepet betöltő HMGB fehérjék) (Masse és mtsai. 2002, Bustin 1999, Grosschedl és mtsai. 1994). Egy tanulmány a HMG-box második hélix elött pozícionálódó aminosavának poláros vagy apoláros jellegét összefüggésbe hozta a fehérje szekvencia-specifikus vagy szekvenciafüggetlen módon történő müködésével (Malarkey és Churchill 2012). Poláros aminosav esetén a fehérje szekvencia-specifikusan, apoláros aminosav esetén nem szekvenciaspecifikusan köti a DNS-molekulát (Malarkey és Churchill 2012). A HMG-box fehérjék 1-7 
HMG-box domént tartalmazhatnak (Stros és mtsai. 2007). A DNS-t szekvencia-specifikus módon kötő, általában transzkripciós faktor funkciójú HMG-box fehérjék általában egy, a nem szekvencia-specifikus fehérjék pedig kettő vagy több kópiában hordoznak HMG-box domént (Stros és mtsai. 2007).

A HMG-box domén a DNS-molekula kis árkába köt, eltorzítva annak gerincét. Nagy affinitással kötődik a nem B-típusú DNS-struktúrákhoz, mint a hajlított DNS, az egyszálú DNS, a „Holliday” struktúra, valamint a „supercoiled” és sérült DNS (Bustin 2010, Stros 2010).

\subsection{A kromatinkapcsolt architektúrális HMG-box fehérjék jellemzése}

2.5.1. A S. cerevisiae modellszervezetben azonositott, architektúrális szerepet betöltö kromatinkapcsolt HMG-box fehérjék

\subsubsection{A Hmo1p és a Hmo2p}

A S. cerevisiae-ben öt architektúrális szerepet betöltő kromatinkapcsolt HMG-box fehérjét azonosítottak. Ezek a Hmo1, Hmo2, Nhp6A, Nhp6B és az Abf2.

A Hmo1 és Hmo2 két HMG-box domént hordoz (Lu és mtsai. 1996). Mindkét fehérje esetében az N-terminális részen található HMG-box a szintén 2 HMG-box domént hordozó humán HMGB1 fehérje első HMG-boxával mutat homológiát, amely jellegzetesen kevéssé konzervált a HMGB1-típusú fehérjék körében. A Hmo1 és Hmo2 C-terminális részén található HMG-box a HMGB1 erősen konzervált második HMG-box kópiájával mutat homológiát (Lu és mtsai. 1996). A C-terminális HMG-boxot követő farki rész a Hmol és Hmo2 esetében eltérő szerveződésű. A Hmo1 C-teminális nyúlványát egy kissé savas régiót követő, erősen lizingazdag bázikus régió jellemzi, a Hmo2 esetében pedig csak egy savas jellegü régió alkotja a C-terminális farokrégiót, hiányzik a lizingazdag bázikus szakasz (Lu és mtsai. 1996). A humán HMGB1 C-terminális nyúlványára egy lizingazdag bázikus régió jellemző, amit egy savas jellegü régió követ (Lu és mtsai. 1996). A Hmo1 és Hmo2 eltérően szerveződő C-terminális nyúlványának nagy szerepe van az eltérő biológiai funkció betöltésében. A Hmol fehérje esetében megállapították hatását a kromatin nukleázérzékenységére, képességét az egyszálú DNS-kötésére, és szerepét a plazmidok stabilitásában (Lu és mtsai. 1996). Ezek alapján kromatinszervező szerepe mellett valószínűsíthetően a DNS-replikációban is részt vesz. Merz és munkatársai (2008) 
kimutatták, hogy a Hmo1 stimulálja a Pol-I transzkripciós aktivitást, és hogy a nukleoszómák hiányában a Hmol fehérje kötődik az aktívan átíródó riboszomális DNS (rDNS) szakaszokon. A Hmo2 fehérje esetében kimutatták annak kötődési képességét a kettős szálú törést szenvedett DNS-molekula végeihez és igazolták, hogy az INO80 komplex részeként részt vesz a duplaszálú DNS-törések javításában (Ray és Grove 2009, 2012).

\subsubsection{Az Nhp6A és Nhp6B}

Kolodrubetz és Burgum (1990) azonosították az egy HMG-box domént tartalmazó Nhp6A és Nhp6B fehérjéket. Kimutatták, hogy a két fehérje paralóg, szerepük pedig redundáns. Kizárólag a dupla deléciós nhp6A/B mutáns esetében észleltek a vad típustól eltérő fenotípust. A mutáns törzs $1 \mathrm{M}$ szorbitol táptalajhoz történő adagolásával kúrálható hőmérséklet-érzékenységet mutatott, valamint a morfológiai eltéréseket (megnyúlt sarjsejtek, láncképzés) a vad típushoz képest (Costigan és mtsai. 1994). Kimutatták, hogy szerepet játszanak az RNS-polimeráz III és több, az RNS-polimeráz II által átírt gén kifejeződésében, valamint számos, a kromatinstruktúra kialakításában, vagy szignáltranszdukciós folyamatokban résztvevő fehérjével alakíthatnak ki kölcsönhatást (Stillman 2010).

\subsubsection{Az Abf2p}

Az Abf2 a S. cerevisiae mitokondriumában lokalizálódó, DNS-kötő HMG-box fehérje. Hiánya pleiotróp hatást eredményez az élesztőben, köztük a mitokondriális kromoszóma instabilitását okozza fermentálható szénforrásokon (MacAlpine és mtsai. 1998, Diffley és Stillman 1991), ami $\rho^{-}$(citoplazmás ,,petite”) törzsek létrejöttéhez vezet. Ezen kívül a mitokondriális DNS szegregációja zavart szenved osztódáskor, szignifikánsan lecsökken a rekombinációs gyakoriság, a mitokondriális DNS transzkripciója pedig sértetlen (Zelenaya-Troitskaya és mtsai. 1998). Újabb tanulmányok bizonyították az Abf2 fehérje szerepét a mitokondriális nukleoid struktúrájának kialakításában (Brewer és mtsai. 2003, Miyakawa és mtsai. 2010). 


\subsubsection{A nukleoidszervezö mitokondriális HMG-box fehérjék áttekintése}

Néhány HMG-box fehérje mitokondriális lokalizációt mutat és képes a mitokondriális DNS-hez kötődve azon hatást kifejteni. Szerkezetükre jellemző, hogy két konzervatív HMG-box domént tartalmaznak, melyeket $\alpha$-hélix struktúra választ el egymástól. Eddig a gombák közül S. cerevisiae-ben (Abf2) (MacAlpine és mtsai. 1998), Candida albicans-ban (Gcf1) (Visacka és mtsai. 2009), C. parapsilosis-ban (CpGcf1) (Miyakawa és mtsai. 2009), Yarrowia lipolytica-ban (YlMhb1) (Bakkaiova és mtsai. 2014), Podospora anserina-ban (MtHmg1) (Dequard-Chablat és Alland 2002), valamint a Physarum polycephalum nyálkagombában (Glom) (Sasaki és mtsai. 2003) írtak le mitokondriális HMG-box fehérjét az alacsonyrendü eukarióták esetében. Magasabbrendü eukariótákban a metazoák széles körében azonosítottak ilyen fehérjéket, mint a Caenorhabditis elegans HMG-5 fehérjéje (Sumitani és mtsai. 2011), vagy a humán Tfam fehérje (Parisi és Clayton 1991).

A S. cerevisiae Abf2 az emlős Tfam fehérjékhez hasonlóan két HMG-box domént tartalmaz. S.cerevisiae-ben az abf2 deléció komplementálható mind a humán (Parisi és mtsai. 1993) mind az egér (Yoon és mtsai. 2011) Tfam fehérjékkel. Azonban ugyanezt sikerült elérni az Escherichia coli HU fehérje kifejeztetésével is (Megraw és Chae 1993), amely nem tartozik a HMG-box fehérjék családjába. Ez alapján úgy tünik, hogy a deléciós fenotípus komplementációjához elégséges egy fehérje DNS-kötő és -hajlító tulajdonsága.

$\mathrm{Az}$ emlős fehérjék részt vesznek a mitokondriális DNS transzkripciójában és a nukleoidok kialakításában (Kaufman és mtsai. 2007), míg az eddig gombákban azonosított mitokondriális HMG-box fehérjék "csak" nukleoidszervező funkcióban vesznek részt. Az emlős Tfam esetében kimutatták, hogy a két HMG-box kötődése a DNS-molekula drasztikus torzulását eredményezi, U-alakúan meghajlott struktúrát hozva létre. A DNS-molekulának ez a torzulása teszi lehetővé a transzkripciós iniciációs komplex bekötődését (Rubio-Cosials és mtsai. 2011, Ngo és mtsai. 2011, Rubio-Cosials és Sola 2013), szerepük tehát esszenciális.

Az egér Tfam gén homozigóta deléciója embrionálisan letális (Larsson és mtsai. 1998). A zsírszövetben létrehozott, célzott deléció a mitokondrium-kópiaszám szövetspecifikus csökkenését eredményezi (Vernochet és mtsai. 2012). Paradox módon a mutáns egerek energia-felhasználása megnő az elhízásra, a kettes típusú diabéteszre és a zsírmáj kialakulására való hajlam csökkenése mellett (Vernochet és mtsai. 2012). Dopaminerg neuronokban végrehajtott delécióval „MitoPark” egerek jöttek létre, melyek Parkinson-szerü 
tüneteket mutattak 20 hetes korukban (Ekstrand és Galter 2009). Az emlösökön kívül Tfamfehérjéket azonosítottak és funkcionálisan jellemeztek már Caenorhabditis elegans-ban (Sumitani és mtsai. 2011), Paracentrotus lividus tengeri sünben (Deceglie és mtsai. 2014) és Gallus gallus-ban is (Matsushima és mtsai. 2003).

A S. cerevisiae-ben található Abf2 szerepét a 2.5.1.3. fejezetben részleteztük. Érdekes, hogy néhány, a Saccharomycetales rendbe tartozó gombából hiányoznak az Abf2-szerü fehérjék, azonban ezekben sikerült azonosítani egy mitokondriális lokalizációs szignált hordozó, másik típusú HMG-box fehérjét, mint pl. a Gcf1-et a Candida albicans-ban (Visacka és mtsai. 2009). A Gcf1 fehérje nem egyértelmủen rokonítható az Abf2 fehérjével, és csak egy konzervált HMG-box szekvenciát tartalmaz kettő helyett. A Gcf1 fehérjét kódoló gén megtalálható a C. albicans-szal rokon fajok pl. a C. parapsilosis (Visacka és mtsai. 2009, Miyakawa és mtsai. 2009) genomjában is. A filogenetikai szempontból az Ascomycota vonal bazális fajának tekintett Yarrowia lipolytica esetében in silico, bioinformatikai módszerekkel nem sikerült mitokondriális lokalizációs szignált hordozó HMG-box fehérjét azonosítani, azonban tisztított nukleoid-kivonatból sikerült azonosítani és tisztítani egy nagy mennyiségben jelen levő fehérjét, a YlMhb1-t, amely teljes mértékben kompelmentálta az abf2 $\Delta$ fenotípust $S$. cerevisiae-ben (Bakkaiova és mtsai. 2014). Csak a fehérje N-terminális szekvenálása után sikerült a kódoló szekvenciát azonosítani a genomban, amelyről kiderítették, hogy, nem szokványos módon az ORF átírása itt GTG-vel (valin kodon) indul és nem ATG-vel. Ily módon tárult fel egy gén, melynek terméke mitokondriális lokalizációs szignált hordoz és két feltételezhető HMG-boxot tartalmaz. Kimutatták, hogy a fehérje köti és csomagolja a mtDNS-t, és hiányában a mtDNS-kópiaszám lecsökken a mitokondriumokban, ami azonban nem jár a mitokondriális légzés kapacitásának megváltozásával (Bakkaiova és mtsai. 2014).

A fonalasgombák esetében a Pezizomycotina gombacsoportba tartozó Podospora anserina fajban egy Abf2-től és Gcf1-től is eltérő HMG-box fehérjét azonosítottak, mely feltehetőleg a mitokondriális DNS-hez kötődik. A P. anserina MtHmg1 fehérjéje az eddigi eredmények szerint a mitokondriumban található. A fehérjét kódoló szekvenciát két kópiában hordozó mutánsban a túltermelés szupresszálta a „korai elhalás” fenotípust, melyet a mitokondriális DNS átrendeződése jellemez (Dequard-Chablat és Allandt 2002). Az mthmgl gén deletálásának hatására csökkent a gomba élettartama, és kialakult egy korai szeneszcens fenotípus, melyben a mitokondriális DNS jellegzetes mintázatú (szeneszcens jellegű) átrendeződését figyelték meg. A deléciós törzs esetében megváltozott a gombafonal morfológiája, női sterilitást mutatott, a deléciós aszkospórákra pedig megkésett csírázás volt 
jellemző. Az MtHmg1 egyetlen konzervált HMG-box domént hordoz a C-terminálison (244.-310. aminosavak), tőle N-terminális irányban egy feltételezett második HMG-box (147.-211. aminosavak), majd attól N-terminálisan egy feltételezett AT-hurok szekvencia (111.-123. aminosavak), valamint az N-terminálison egy feltételezett mitokondriális szignálszekvencia található (Dequard-Chablat és Allandt 2002).

A nyálkagomba (Amoebozoa) és az Opistokonta (ide tartoznak az állatok és a gombák) csoportok körülbelül 1,5 milliárd évvel ezelött váltak el egymástól (Hedges és Shah 2003). A $P$. polycephalum valódi nyálkagombában a két konzervált HMG-box domént tartalmazó Glom fehérje felelős a mitokondriális nukleoid becsomagolásáért (Sasaki és mtsai. 2003).

Mindezen eredmények a DNS-csomagoló mechanizmus extrém konzerváltságát jelzik a kromatinkapcsolt architektúrális HMG-box fehérjék esetében. 


\section{CÉLKITŰZÉS}

Mivel a régóta kutatott fonalasgomba modellszervezetben, az A. nidulans-ban egyetlen architektúrális HMG-box fehérjét sem azonosítottak eddig annak ellenére, hogy széles körben kutatják eme modellszervezet kromatinszerveződését és funkcióját, célul tüztük ki a feltételezett architektúrális HMGB-fehérjék azonosítását és élettani szerepének felderítését.

A megvalósításhoz bioinformatikai vizsgálatokon alapuló azonosítást és jellemzést követő reverz genetikai és molekuláris biológiai módszerekkel történő vizsgálatokat terveztünk (génexpresszió vizsgálat; deléció; GFP-vel fúzionált fehérje lokalizációjának vizsgálata; a deléciós vegetatív és szexuális spórák csírázóképességének vizsgálata; a deléciós törzsek növekedési képességének tesztelése különböző szén- és nitrogénforrásokon, eltérő pH-n, eltérő hőmérsékleten, oxidatív- és ozmotikus stressz ágensek jelenlétében; a deléciós törzsek másodlagos metabolit termelésének monitorozása, a rekonstitúciós és GFP-vel fúzionált fehérjét kifejező törzsek fenotípus komplementáció képességének vizsgálata, valamint a kapott eredményeket magyarázó molekuláris folyamatok kiderítése).

Mivel a HmbB szekvenciája mitokondriális és sejtmagi lokalizációs szignálszekvenciát is hordoznak, ezért a vizsgálatok elkezdésekor a $h m b B \Delta$ mutáns vizsgálatára terelődött a hangsúly, mivel kettős lokalizációt mutató gomba mitokondriális HMG-box fehérjét még eddig nem írtak le a szakirodalomban. 


\section{FELHASZNÁLT ANYAGOK ÉS MÓDSZEREK}

\subsection{Mikroorganizmusok}

4.1.1. I. táblázat: A. nidulans törzsek. A genotípusok esetében alkalmazott jelölések magyarázatát az I. függelék tartalmazza.

\begin{tabular}{|c|c|c|c|}
\hline Törzs & Genotípus & Felhasználás & Hivatkozás \\
\hline HZS.118 & pabaAl; veAl & $\begin{array}{l}\text { vad típusú kontroll } \\
\text { törzs növekedési } \\
\text { tesztekhez, } \\
\text { aszkospóratermelés, } \\
\text { csírázás, } \\
\text { enzimaktivitás és } \\
\text { oxigénfogyasztás } \\
\text { vizsgálatához, hmbA4 } \\
\text { és } h m b B \triangle \text { törzsek } \\
\text { esetén }\end{array}$ & jelen munka \\
\hline HZS.120 & riboB2; pabaAl; veAl; & $\begin{array}{l}\text { vad típusú kontroll } \\
h m b B \Delta \text { törzs esetén } \\
\text { transzkripció és } \\
\text { másodlagos metabolit } \\
\text { termelés } \\
\text { vizsgálatához, } \\
\text { transzformációs } \\
\text { recipiens törzs a } \\
h m b A \text { és } h m b B \\
\text { deléciós törzs } \\
\text { létrehozásához }\end{array}$ & $\begin{array}{l}\text { (Hamari és mtsai. } \\
\text { 2009) }\end{array}$ \\
\hline HZS.140 & anAl; pantoB100, veAl & $\begin{array}{l}\text { szülői törzs, } \\
\text { keresztezésekhez } \\
\text { HZS.212 és HZS.213 } \\
\text { törzsekkel }\end{array}$ & jelen munka \\
\hline HZS.205 & 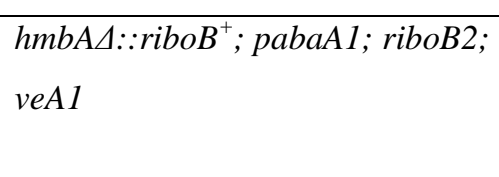 & növekedési tesztek & $\begin{array}{l}\text { jelen munka } \\
\text { (elsődleges } \\
\text { transzformáns/2) }\end{array}$ \\
\hline HZS.212 & 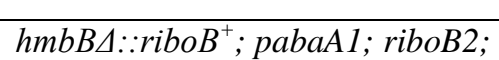 & szülői törzs, & jelen munka \\
\hline
\end{tabular}




\begin{tabular}{|c|c|c|c|}
\hline & veAl & $\begin{array}{l}\text { keresztezésekhez } \\
\text { HZS.140 és HZS.227 } \\
\text { törzsekkel; } \\
\text { növekedési tesztek }\end{array}$ & $\begin{array}{l}\text { (elsődleges } \\
\text { transzformáns/2) }\end{array}$ \\
\hline HZS.213 & $\begin{array}{l}\text { hmbBA::riboB }{ }^{+} ; \text {pabaA1; riboB2; } \\
\text { veAl }\end{array}$ & $\begin{array}{l}\text { szülöi törzs } \\
\text { keresztezéshez } \\
\text { HZS.140 törzzsel; } \\
\text { növekedési tesztek }\end{array}$ & $\begin{array}{l}\text { jelen munka } \\
\text { (elsődleges } \\
\text { transzformáns/20) }\end{array}$ \\
\hline HZS.227 & riboB2, pantoB100, yA2, veA1 & $\begin{array}{l}\text { szülői törzs } \\
\text { keresztezésekhez } \\
\text { HZS.212 és HZS.213 } \\
\text { törzzsel }\end{array}$ & $\begin{array}{l}\text { jelen munka (utód } \\
\text { a } \\
\text { HZS.120xNA031 } \\
3 \text { keresztezésből) }\end{array}$ \\
\hline HZS.314 & $\begin{array}{l}\text { riboB2; pantoB100; pabaA; biAl; } \\
\text { veAl }\end{array}$ & $\begin{array}{l}\text { transzformációs } \\
\text { recipiens törzs a } \\
h m b C \text { deléciós törzs } \\
\text { létrehozásához }\end{array}$ & jelen munka \\
\hline HZS.318 & $\begin{array}{l}\text { hmbBA::riboB }{ }^{+} \text {; pantoB100; } \\
\text { pabaA1; veA1; riboB2 }\end{array}$ & $\begin{array}{l}\text { transzformációs } \\
\text { recipiens törzs a } \\
h m b B-G F P \text { fúziós } \\
\text { törzs létrehozásához }\end{array}$ & $\begin{array}{l}\text { jelen munka (utód } \\
\text { a } \\
\text { HZS.212xHZS.22 } \\
7 \text { keresztezésből) }\end{array}$ \\
\hline HZS.335 & $\begin{array}{l}\text { pAN-HZS-3 vektor transz régióba } \\
\text { integrálódva; } h m b B \Delta:: r i b o B^{+} ; \\
\text {pabaA1; veA1; (pantoB100), } \\
\text { riboB2 }\end{array}$ & $\begin{array}{l}\text { fluoreszcens } \\
\text { mikroszkópia }\end{array}$ & $\begin{array}{l}\text { jelen munka ( } g f p \text { - } \\
h m b B \text { fúziós } \\
\text { konstrukciót és } \\
\text { pantoB }{ }^{+} \text {markert } \\
\text { hordozó pAN- } \\
\text { HZS-3 vektor } \\
\text { HZS.318 törzsbe } \\
\text { transzformálva) }\end{array}$ \\
\hline HZS.338 & $\begin{array}{l}\text { hmbCA::pabaA }{ }^{+} ; \text {riboB2; } \\
\text { pantoB100; biAl; veAl (pabaAl) }\end{array}$ & növekedési tesztek & $\begin{array}{l}\text { jelen munka } \\
\text { (elsődleges } \\
\text { transzformáns/1) }\end{array}$ \\
\hline HZS.348 & $\begin{array}{l}\text { "pantoB }{ }^{+} h m b B-g f p \text { fúziós } \\
\text { konstrukció"-riboB }{ }^{+} \\
\text {(pantoB100); pabaAl; veAl } \\
\text { riboB2 }\end{array}$ & $\begin{array}{l}\text { fluoreszcens } \\
\text { mikroszkópia }\end{array}$ & $\begin{array}{l}\text { jelen munka } \\
\text { ("pantoB }{ }^{+} h m b B \text { - } \\
g f p \text { fúziós } \\
\text { konstrukció" } \\
\text { HZS.318 törzsbe }\end{array}$ \\
\hline
\end{tabular}




\begin{tabular}{|c|c|c|c|}
\hline & & & transzformálva) \\
\hline HZS.349 & $\begin{array}{l}\text { "panto }{ }^{+} h m b B-g f p \text { fúziós } \\
\text { konstrukció"-riboB }{ }^{+} ; \\
\text {(pantoB100); pabaAl; veAl } \\
\text { riboB2 }\end{array}$ & $\begin{array}{l}\text { fluoreszcens } \\
\text { mikroszkópia }\end{array}$ & $\begin{array}{l}\text { jelen munka } \\
\text { ("panto }{ }^{+} h m b B \text { - } \\
\text { gfp fúziós } \\
\text { konstrukció" } \\
\text { HZS.318 törzsbe } \\
\text { transzformálva) }\end{array}$ \\
\hline HZS.352 & $\begin{array}{l}\text { pAN-HZS-4 vektor transz régióba } \\
\text { integrálódva; } \triangle h m b B:: \text { ribo }^{+} ; \\
\text {pabaAl; veAl; } \\
\text { (pantoB100);riboB2 }\end{array}$ & $\begin{array}{l}\text { a deléciós fenotípus } \\
\text { komplementációjának } \\
\text { vizsgálata a HmbB } \\
\text { fehérje } \\
\text { visszatranszformálásá } \\
\text { val }\end{array}$ & $\begin{array}{l}\text { jelen munka } \\
\text { ( } h m b B \text {-His-Tag } \\
\text { fúziós } \\
\text { konstrukciót és } \\
{\text { panto } B^{+} \text {markert }}_{\text {tartalmazó pAN- }} \\
\text { HZS-4 integratív } \\
\text { vektor HZS.318 } \\
\text { törzsbe } \\
\text { transzformálva) }\end{array}$ \\
\hline HZS.358 & $\begin{array}{l}\text { "panto } B^{+} h m b B-g f p \text { fúziós } \\
\text { konstrukció"- ribo } B^{+} ; \text {hhoA- } \\
m R F P-A f r i b o B^{+} ;(\text {riboB2); veAl }\end{array}$ & $\begin{array}{l}\text { fluoreszcens } \\
\text { mikroszkópia }\end{array}$ & $\begin{array}{l}\text { jelen munka (utód } \\
\text { a HZS.349x } \\
\text { LO1516 } \\
\text { keresztezésből) }\end{array}$ \\
\hline HZS.359 & $\begin{array}{l}\text { "panto }{ }^{+} h m b B-g f p \text { fúziós } \\
\text { konstrukció"-riboB } B^{+} \text {;hoA- } \\
m R F P-A f r i b o B^{+} ; \text {pyroA4; } \\
\text { pabaAl(riboB2); veAl }\end{array}$ & $\begin{array}{l}\text { heterokarion-képzés } \\
\text { HZS.385 törzzsel }\end{array}$ & $\begin{array}{l}\text { jelen munka (utód } \\
\text { a HZS.349x } \\
\text { LO1516 } \\
\text { keresztezésből) }\end{array}$ \\
\hline HZS.363 & $\begin{array}{l}\text { "panto } B^{+} \text {gfp- } h m b B \text { fúziós } \\
\text { konstrukció"- riboB } B^{+} ; \text {pabaAl; } \\
\text { (pantoB100); riboB2; veAl }\end{array}$ & $\begin{array}{l}\text { fluoreszcens } \\
\text { mikroszkópia }\end{array}$ & $\begin{array}{l}\text { jelen munka } \\
\text { ("panto }{ }^{+} g f p- \\
\text { hmbB fúziós } \\
\text { konstrukció" } \\
\text { HZS.318 törzsbe } \\
\text { transzformálva) }\end{array}$ \\
\hline HZS.366 & $\begin{array}{l}\text { "panto } B^{+} \text {gfp-hmbB fúziós } \\
\text { konstrukció"- ribo } B^{+} ; \text {hhoA- } \\
m R F P- \\
\text { Afribo } B^{+} ;(\text {riboB2);(pantoB100);ve } \\
\text { Al }\end{array}$ & $\begin{array}{l}\text { fluoreszcens } \\
\text { mikroszkópia }\end{array}$ & $\begin{array}{l}\text { jelen munka (utód } \\
\text { a } \\
\text { HZS.363xLO1516 } \\
\text { keresztezésből) }\end{array}$ \\
\hline
\end{tabular}




\begin{tabular}{|c|c|c|c|}
\hline HZS.385 & $\begin{array}{l}\text { hmbBA::riboB }{ }^{+} ; \text {pantoB100; yA2; } \\
\text { (riboB2); veAl }\end{array}$ & $\begin{array}{l}\text { heterokarion-képzés } \\
\text { LO1516 és HZS.359 } \\
\text { törzsekkel }\end{array}$ & $\begin{array}{l}\text { jelen munka (utód } \\
\text { a } \\
\text { HZS.212xHZS.22 } \\
7 \text { keresztezésböl }\end{array}$ \\
\hline LO1516 & $\begin{array}{l}\text { hhoA-mRFP-AfriboB; pyroA4; } \\
\text { pyrG89; nkuA } \triangle:: \arg B+\end{array}$ & $\begin{array}{l}\text { szülői törzs a } \\
\text { HZS.349 és HZS.363 } \\
\text { törzsekkel történő } \\
\text { keresztezéshez, } \\
\text { heterokarion-képzés } \\
\text { HZS.385 törzzsel }\end{array}$ & $\begin{array}{l}\text { (Nayak és mtsai. } \\
\text { 2010) }\end{array}$ \\
\hline NA0313 & pantoB100; yA2; veA1; & $\begin{array}{l}\text { törzs keresztezéshez } \\
\text { HZS.120 törzzsel }\end{array}$ & $\begin{array}{l}\text { (Robellet és mtsai. } \\
\text { 2010) }\end{array}$ \\
\hline
\end{tabular}

\subsubsection{Escherichia coli törzs}

\begin{tabular}{|l|l|l|l|}
\hline Törzs & Genotípus & Felhasználás & Hivatkozás \\
\hline XL-1 & recA1, endA1, gyrA96, thi, hsdR17( $\mathrm{r}_{\mathrm{K}}-$, & vektor- & (Cammack és mtsai. \\
Blue & $\left.\mathrm{m}_{\mathrm{K}}+\right)$, supE44, relA1, lac, $\left[\mathrm{F}^{\prime}\right.$, proAB+, & konstrukciók & $2006)$ \\
& $\left.\operatorname{lacl}^{\mathrm{q}} \mathrm{Z} \Delta \mathrm{M} 15,:: \operatorname{Tn} 10\left(\mathrm{Tet}^{\mathrm{r}}\right)\right]$ & felszaporítása & \\
\hline
\end{tabular}

\subsection{Tenyésztési körülmények}

\subsubsection{A. nidulans tenyésztésére felhasznált táptalajok}

Minimál tápoldat $(\mathrm{MM})$ :

$2 \%(\mathrm{v} / \mathrm{v})$ sóoldat, szénforrás, nitrogénforrás $(\mathrm{pH} 6,8)$

Komplett tápoldat (CM):

$2 \%$ (v/v) sóoladt, $1 \mathrm{~m} / \mathrm{v} \%$ glükóz, $2 \mathrm{~g} / \mathrm{l}$ peptonn $\left(\right.$ Bacto $^{\mathrm{TM}}$ ), $1,5 \mathrm{~g} / \mathrm{l}$ kazaminosavak $\left(\right.$ Bacto $\left.^{\mathrm{TM}}\right), 1 \mathrm{~g} /$ l élesztőkivonat $\left(\right.$ Bacto $\left.^{\mathrm{TM}}\right)(\mathrm{pH} 6,8)$

Szacharózos minimál tápoldat $(\mathrm{SM})$ :

2\% (v/v) sóoldat, 1 m/v\% glükóz, 342,3g/l szacharóz, 0,85 g/1 NaNO 3 (PH 6,8) 
Sóoldat:

$26 \mathrm{~g} / \mathrm{l} \mathrm{KCl}, 26 \mathrm{~g} / 1 \mathrm{MgSO}_{4} \times 7 \mathrm{H}_{2} \mathrm{O}, 76 \mathrm{~g} / 1 \mathrm{KH}_{2} \mathrm{PO}_{4}, 5 \%$ (v/v) nyomelem-törzsoldat

Nyomelem-törzsoldat:

$40 \mathrm{~g} / \mathrm{l} \mathrm{Na}$-borát $\left(\mathrm{Na}_{2} \mathrm{~B}_{4} \mathrm{O}_{7} \times 10 \mathrm{H}_{2} \mathrm{O}\right), 400 \mathrm{mg} / \mathrm{l} \mathrm{CuSO}{ }_{4} \times 5 \mathrm{H}_{2} \mathrm{O}, 714 \mathrm{mg} / \mathrm{l} \mathrm{FePO}, 728 \mathrm{mg} / \mathrm{l}$ $\mathrm{MnSO}_{4} \times \mathrm{H}_{2} \mathrm{O}, 800 \mathrm{mg} / \mathrm{l} \mathrm{Na} 2 \mathrm{MoO}_{4} \times 2 \mathrm{H}_{2} \mathrm{O}, 8 \mathrm{mg} / \mathrm{Z} \mathrm{ZnSO}_{4} \times 7 \mathrm{H}_{2} \mathrm{O}$

Szénforrások és felhasználási koncentrációjuk:

etanol: $2 \%(\mathrm{v} / \mathrm{v})$, galaktóz: $1 \mathrm{~m} / \mathrm{v} \%$, glicerin: $2 \%(\mathrm{v} / \mathrm{v})$, glükóz: $1 \mathrm{~m} / \mathrm{v} \%$, laktóz: $1 \mathrm{~m} / \mathrm{v} \%$, maltóz: $1 \mathrm{~m} / \mathrm{v} \%$, raffinóz: $3 \mathrm{~m} / \mathrm{v} \%$, szacharóz: $1 \mathrm{~m} / \mathrm{v} \%$, szorbitol: $1 \mathrm{~m} / \mathrm{v} \%$, xilóz: $1 \mathrm{~m} / \mathrm{v} \%$

Nitrogénforrások és felhasználási koncentrációjuk:

allantoin: 0,1 g/l, ammónium-tartarát: $0,97 \mathrm{~g} / 1$, hipoxantin: $0,1 \mathrm{~g} / 1, \mathrm{NaNO}_{3}: 0,85 \mathrm{~g} / 1$, urea: $0,3 \mathrm{~g} / \mathrm{l}$, húgysav: $1 \mathrm{~g} / \mathrm{l}$

Vitaminok és felhasználási koncentrációjuk:

pantoténsav: $40 \mu \mathrm{g} / \mathrm{l}$, para-amino-benzoesav: $40 \mu \mathrm{g} / \mathrm{l}$, riboflavin: $50 \mu \mathrm{g} / \mathrm{l}$, piridoxin: $25 \mu \mathrm{g} / \mathrm{l}$, biotin: $0,1 \mu \mathrm{g} / 1$, tiamin: $50 \mu \mathrm{g} / 1$

Szerves bázisok és felhasználási koncentrációjuk:

uracil: $1 \mathrm{~g} / \mathrm{l}$, uridin: $1 \mathrm{~g} / \mathrm{l}$

\subsubsection{Az A. nidulans tenyésztési körülményei}

Táptalajok esetében a tápoldatot $3 \mathrm{~m} / \mathrm{v} \%$ agarral egészítettük ki. Szacharózos minimál táptalaj esetén 1 és $3 \mathrm{~m} / \mathrm{v} \%$ agartartalmú táptalajt is használtunk. Táptalajon történő nevelés során a felhasznált törzsek $0,01 \mathrm{~m} / \mathrm{v} \%$ Tween 80 oldatban készített konídiumszuszpenzióit steril fogpiszkáló segítségével pontba oltottuk és sötétben, $37{ }^{\circ} \mathrm{C}$-on inkubáltuk. Folyadékkultúrák esetében $10^{8}$ konídiumot oltottunk $300 \mathrm{ml}$ MM-tápoldatba és $37^{\circ} \mathrm{C}$-on inkubáltuk $180 \mathrm{rpm}$ rázatás mellett 3 óráig (izotropikus növekedés fázisa), 22 óráig (micéliális fázis), vagy 36 óráig (micéliális fázis). 


\subsubsection{A csírázó és nem csírázó konídiumok elkülönitése a hmbBد törzs esetében}

A csírázó és nem csírázó konídiumok elkülönítése a nyugvó és csírázásnak indult konídiospórák üvegfelülethez történő eltérő adhézióján alapul. $2 \times 10^{9}$ konídiumot oltottunk 2 literes üveg Roux-flaskába $200 \mathrm{ml}$ MM-tápoldatba, majd $37{ }^{\circ} \mathrm{C}$-on inkubáltuk az elfektetett Roux-flaskákat 8 órán keresztül, rázatás nélkül. Ezt követően a nem csírázó konídiumokat a tápoldat leöntésével eltávolítottuk. Az üvegfelületre kitapadt csírázó konídiumokat steril sejtkaparóval összegyüjtöttük, majd $300 \mathrm{ml}$ MM-tápoldatba oltva 500 ml-es Erlenmeyer lombikban tovább inkubáltuk $37^{\circ} \mathrm{C}$-on 180 rpm rázatás mellett.

\subsubsection{E.coli tenyésztéséhez felhasznált táptalajok}

Luria-Bertani (LB) tápoldat: tripton: $10 \mathrm{~g} / 1, \mathrm{NaCl}: 10 \mathrm{~g} / 1$, élesztőkivonat: $5 \mathrm{~g} / 1$

Táptalajok esetében a tápoldatot $2 \mathrm{~m} / \mathrm{v} \%$ agarral egészítettük ki. Transzformánsok szelektálásához és felszaporításához a tápoldatot, vagy a táptalajt $50 \mu \mathrm{g} / \mathrm{ml}$ ampicillinnel is kiegészítettük.

4.3. II. táblázat: Felhasznált vektorok

\begin{tabular}{|c|c|c|}
\hline Név & Felhasználás & Referencia \\
\hline pAN52-1 & pANHZS-1 vektor létrehozása & Punt és mtsai. 1987 \\
\hline pANHZS-1 & $\begin{array}{l}\text { pANHZS-2; pANHZS-3, pANHZS-4 vektorok } \\
\text { létrehozása }\end{array}$ & $\begin{array}{l}\text { jelen munka, 4.10.1. } \\
\text { szakasz }\end{array}$ \\
\hline pANHZS-2 & $h m b B-g f p$ fúziós konstrukció létrehozása & $\begin{array}{l}\text { jelen munka, 4.10.1. } \\
\text { szakasz }\end{array}$ \\
\hline pANHZS-3 & $g f p-h m b B$ fúziós konstrukció létrehozása & $\begin{array}{l}\text { jelen munka, 4.10.2. } \\
\text { szakasz }\end{array}$ \\
\hline pANHZS-4 & hmbB-his-tagfúziós konstrukció létrehozása & $\begin{array}{l}\text { jelen munka, } 4.10 .3 \\
\text { szakasz }\end{array}$ \\
\hline
\end{tabular}

4.4. III. táblázat: Felhasznált indítószekvenciák

\begin{tabular}{|c|c|}
\hline \multicolumn{2}{|c|}{ Kvantitatív valós idejű polimeráz láncreakció (qRT-PCR) } \\
\hline \multicolumn{2}{|c|}{ A hmbB, aktin, ndhB és oxiB gének } \\
\hline hmbB ReTi frw & 5'- AAGACTACAAAGACCAAGAAGACC -3' \\
\hline hmbB ReTi rev & 5'- TTGCTCCTCAGTCAGAACCT -3' \\
\hline actin ReTi frw & 5'- GGTATCATGATCGGTATGGG -3' \\
\hline actin ReTi rev & 5'- TATCTGAGTGTGAGGATACCA -3' \\
\hline ndhB ReTi frw & 5'- TATCATTTGCAGGTATTCCTCCTT -3' \\
\hline ndhB ReTi rev & 5' - TAAATCCTTCTTGTAAAGCAGCAG-3' \\
\hline
\end{tabular}




\begin{tabular}{|c|c|}
\hline oxiB ReTi frw & 5'- GGACACATTCTAATGGATGCAC -3' \\
\hline oxiB ReTi rev & 5'- CCTCTATTCCTTCCATTTGTGGT -3' \\
\hline \multicolumn{2}{|c|}{ A sterigmatocisztin-bioszintézis génjei és a klaszterregulátor gén } \\
\hline aflR ReTi frw & 5'- CGAATACTTCCACCTCCACC -3' \\
\hline aflR ReTi rev & 5' - TACCCTCAAGAAGCGAAGGA -3' \\
\hline stcU ReTi frw & 5'- CATTTCCATTCAAGCCGATGTC-3' \\
\hline stcU ReTi rev & 5'-ATGAGACTATATCCAGGTATCCGA -3' \\
\hline stcO ReTi frw & 5'- CTGCATGGACAAGGTGTAGG -3' \\
\hline stcO ReTi rev & 5'- TCCTCCCTCTAGCAAGAACC -3' \\
\hline \multicolumn{2}{|c|}{ A glutation-S-transzferáz gének } \\
\hline gstA ReTi frw & 5'- CTCGCTGAGCAATATGATAAAGAC -3' \\
\hline gstA ReTi rev & 5'- ATACAGCCAGCTGATTGTCTC -3' \\
\hline gstB ReTi frw & 5'- GCAATACTACTCTGAGCGTCC -3' \\
\hline gstB ReTi rev & 5'- CTCCTCTCGTTATCGATGCTC -3' \\
\hline an10273 ReTi frw & 5'- AGAGTCATTCGCAGATCAACC -3' \\
\hline an10273 ReTi rev & 5'- GCTTTACAGCATTCACCTCCT -3' \\
\hline an0815 ReTi frw & 5'- TATAATACCCGCGAAAGATGGA -3' \\
\hline an0815 ReTi rev & 5'- CAGACCAACGAATACTCTAATCAG -3' \\
\hline an2948 ReTi frw & 5'- CAAGACTGCGGATGAGAAGG -3' \\
\hline an2948 ReTi rev & 5'- CACCCATTGATAACAGGCGT -3' \\
\hline an5831 ReTi frw & 5'- GAGTTTGATCACTTACTGCCC -3' \\
\hline an5831 ReTi rev & 5'- GTTCATCGCCTCAATCTCAC -3' \\
\hline an6158 ReTi frw & 5'-CTGGGATTCATCCATGGTGTC -3' \\
\hline an6158 ReTi rev & 5'- AGCTTTACATTGCTCAATGCTG -3' \\
\hline \multicolumn{2}{|c|}{ A glutation-oxidoreduktáz gének } \\
\hline gpxA ReTi frw & 5'- GGCAAAGTTATCCTTGTCGTC -3' \\
\hline gpxA ReTi rev & 5'- GCTTTGATGGACTGGTAAAGG -3' \\
\hline an3255 ReTi frw & 5'- CGGTCCTGAATGAACTAGGAG -3' \\
\hline an3255 ReTi rev & 5'- GGGTTGATGTTGATGAACGG -3' \\
\hline an4215 ReTi frw & 5'- GCTCCAGCATCCTTTAACAG -3' \\
\hline an4215 ReTi rev & 5'- GTTCCCAACATCTACATTGCC -3' \\
\hline an4304 ReTi frw & 5'- CCTGAACAAGGAGTTTATTGGTG -3' \\
\hline an4304 ReTi rev & 5'- GCAACTAGGACACCCTTCTC -3' \\
\hline \multicolumn{2}{|c|}{ A glutation-reduktáz gének } \\
\hline glrA ReTi frw & 5'- ATCCAATGATCCAGAAGACCA -3' \\
\hline glrA ReTi rev & 5'- GCTGAACCTCCTTGATACCA -3' \\
\hline \multicolumn{2}{|c|}{ A tioredoxin-reduktáz gének } \\
\hline trxR ReTi frw & 5'- CTCAAGCCTGTCCTTTACGA -3' \\
\hline trxR ReTi rev & 5' - AAACCGGGAAAGTTCTCGAC -3' \\
\hline \multicolumn{2}{|l|}{ A kataláz gének } \\
\hline catB ReTi frw & 5'- GGAAGCTCAGCAAATTTCTGG -3' \\
\hline catB ReTi rev & 5'- CACGTTAAGCTCCCACTCAG -3' \\
\hline \multicolumn{2}{|c|}{ A flavohemoprotein gének } \\
\hline fhbA ReTi frw & 5'-CGTCATCACCTCGTTCTACC -3' \\
\hline fhbA ReTi rev & 5'-CACCTGGATAGAGACGTACTG -3' \\
\hline \multicolumn{2}{|c|}{ A nitroreduktáz gének } \\
\hline an2343 ReTi frw & 5'- CGCTCTCAAGGACATCAAGG -3' \\
\hline an2343 ReTi rev & 5'- AAGTACTGAGACATGGCATTGG -3' \\
\hline \multicolumn{2}{|c|}{ A szuperoxid-dizmutáz gének } \\
\hline sodA ReTi frw & 5'-GATAAGCTGATCAAGCTCATTGG -3' \\
\hline sodA ReTi rev & 5'-GCCAAGGTCATCAGTACCAG -3' \\
\hline sodB ReTi frw & 5'-GTATTGATGCTTGGGAGCAC -3' \\
\hline sodB ReTi rev & 5'-GTTGATGACCTCCCAGATCG -3' \\
\hline sodM ReTi frw & 5'-CAAACTGGACATTGTGACGAC -3' \\
\hline sodM ReTi rev & 5'-CAAACTGGACATTGTGACGAC -3' \\
\hline
\end{tabular}




\begin{tabular}{|c|c|}
\hline \multicolumn{2}{|c|}{ A HmbB-GFP fúziós konstrukció klónozása } \\
\hline pantoB NdeI frw & $\begin{array}{l}\text { 5'- TTTTTTCATATGGCATAGCCATCAAGATGCGACTCTGAACC - } \\
3 \text {, }\end{array}$ \\
\hline pantoB $N d e$ I rev & 5' - TTTTTTCATATGACATAATCTTATGATCCATACCACCTAGC -3' \\
\hline hmbB NcoI frw & 5'-TTTTTTTTCCATGGCTCTCAAACTCATTCGACG-3' \\
\hline hmbB linker $N c o$ I rev & $\begin{array}{l}\text { 5'- }^{\prime} \\
\text { TTTTTTTCCATGGAATCAAGATCGACTGTATCAATAAGTTCATC } \\
\text { CTTGCTCGATTTCTTGTTCC-3' }\end{array}$ \\
\hline$\Delta$ st chim frw & $\begin{array}{l}\text { 5'- } \\
\text { CCTATACCGTCAGTGAACCTCGCCATGGCTCTCAAACTCATTCG } \\
\text { ACG-3' }\end{array}$ \\
\hline $\begin{array}{l}\text { pantoB hmbB down kim } \\
\text { rev }\end{array}$ & $\begin{array}{l}\text { 5'- } \\
\text { GTAGAGATATGATAGGTTGATCAACAACGCGCACACATAATCTT } \\
\text { ATGATCCATACCACCTAGC-3' }\end{array}$ \\
\hline \multicolumn{2}{|c|}{ A GFP-HmbB fúziós konstrukció klónozása } \\
\hline pGPD int frw & 5'- CAGTATATTCATCTTCCCATCCAAGAAC -3' \\
\hline GFP linker chim rev & $\begin{array}{l}\text { 5'- } \\
\text { ATCAAGATCGACTGTATCAATAAGCTTGTACAGCTCGTCCATG } \\
\text { CCGTG -3' }\end{array}$ \\
\hline hmbB linker chim frw & $\begin{array}{l}\text { 5'- } \\
\text { ACAAGCTTATTGATACAGTCGATCTTGATATGCCTCTCAAACT } \\
\text { CATTCGACG -3' }\end{array}$ \\
\hline hmbB down rev2 & 5'- GTTCTACACTGAGGTACATTCAAGG -3' \\
\hline 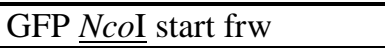 & 5'- TTTTTTTTCCATGGTGAGCAAGGGCGAGGAGC -3' \\
\hline hmbB N $\underline{\text { BamHI rev }}$ & 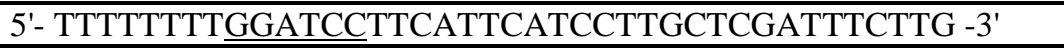 \\
\hline \multicolumn{2}{|c|}{ A Hisztidin-taggelt $h m b B$ klónozása } \\
\hline hmbB NcoI frw & 5'-TTTTTTTTCCATGGCTCTCAAACTCATTCGACG-3' \\
\hline hmbB HisTag $\underline{\text { BamHI rev }}$ & $\begin{array}{l}\text { '’- } \\
\text { TTTTTTTTGGATCCTCAATGATGATGATGATGATGTTCATCCTT } \\
\text { GCTCGATTTCTTG-3' }\end{array}$ \\
\hline \multicolumn{2}{|l|}{ A $h m b B$ deléciója } \\
\hline hmbB upst frw & 5'- CTTCGACAATCTGCGTAATCTCAGGCGCAACG -3' \\
\hline hmbB upst rev & 5'- CGCGAGGTTCACTGACGGTATAGGATGCC -3' \\
\hline hmbB upst nest frw & 5'- GTCCTTATGAATCTGTGTCGCCAACTCTCG -3' \\
\hline hmbB ribo chim frw & $\begin{array}{l}\text { 5'- } \\
\text { GGCATCCTATACCGTCAGTGAACCTCGCGCGTACGTAGTGTAG } \\
\text { ATTCAGGCACATTGAAGCG-3' }\end{array}$ \\
\hline hmbB ribo chim rev & $\begin{array}{l}\text { 5'- } \\
\text { GTAGAGATATGATAGGTTGATCAACAACGCGCACGGAAAACTG } \\
\text { CCATGACTACTAGGTGGTGCTATC -3' }\end{array}$ \\
\hline hmbB down frw & 5'- GTGCGCGTTGTTGATCAACCTATCATATCTCTAC -3' \\
\hline hmbB down rev & 5'- CACCGTCACCACCGTTATCACCGTCGTCATC -3' \\
\hline hmbB down nest rev & 5'- GTTAACACAGCATCGCGGACTATGCTCC -3' \\
\hline \multicolumn{2}{|l|}{ A $h m b B$ gén felszaporítása } \\
\hline hmbB frw & 5'- ATGCCTCTCAAACTCATTCGACG -3' \\
\hline hmbB rev & 5'- TTCATCCTTGCTCGATTTCTTG -3' \\
\hline \multicolumn{2}{|l|}{ A $h m b A$ gén deléciója } \\
\hline hmbA upst frw & 5'- CTCTGACCTGCCACGAGGCCTTGCTCTATG-3' \\
\hline hmbA upst rev & 5'- GGTGAAGGTCTGAAGCTGTTGGACGAAGAG3' \\
\hline hmbA upst nested frw & 5'- GGAGACATTTCGAACTGTATCAGGGCTAAC-3' \\
\hline hmbA ribo chim frw & $\begin{array}{l}\text { '- } \\
\text { CTCTTCGTCCAACAGCTTCAGACCTTCACCCGTACGTAGTGTA } \\
\text { GATTCAGGCACATTGAAGCG -3' }\end{array}$ \\
\hline hmbA ribo chim rev & $\begin{array}{l}\text { 5'- } \\
\text { CGGAGGTCAAGCGACTCGACACTAAGGTGGGAAAACTGCCAT } \\
\text { GACTACTAGGTGGTGCTATC-3' }\end{array}$ \\
\hline hmbA down frw & 5'- CACCTTAGTGTCGAGTCGCTTGACCTCCG -3' \\
\hline
\end{tabular}




\begin{tabular}{|c|c|}
\hline hmbA down rev & 5' - GCATACAATGCGAGCACGGTGGTCGTCATC -3’ \\
\hline hmbA down nested rev & 5'- CGGTGCTGTTGCTGCTTGAGGACGAGGAG -3' \\
\hline \multicolumn{2}{|c|}{ A $h m b A$ gén felszaporítása } \\
\hline hmbA frw & $\begin{array}{l}\text { 5'- TTTTTTGGTACCATGCCTAAGGCCAATCCTACCCGCAAGACC } \\
-3 \text {, }\end{array}$ \\
\hline hmbA rev & $\begin{array}{l}\text { 5'- } \\
\text { TTTTTTTTGCGGCCGCTTAGGACGACTCCTCATCCTCTTCGGCTT } \\
\text { C -3, }\end{array}$ \\
\hline \multicolumn{2}{|l|}{ A $h m b C$ gén deléciója } \\
\hline hmbC upst frw & 5'- GCTGTATTACGTCATGTACGGAGTAG -3' \\
\hline hmbC upst rev & 5- GCGAGGAATGGGTATGCTAGTTG -3' \\
\hline hmbC upst nested frw & 5'- CTGACATTGAGATTCTGAGCCACAAC -3' \\
\hline hmbC paba chim frw & $\begin{array}{l}\text { 5'- } \\
\text { CAACTAGCATACCCATTCCTCGCGCACATAGCTATTACACGTA } \\
\text { TGTTTGAGAC -3' }\end{array}$ \\
\hline hmbC paba chim rev & $\begin{array}{l}\text { 5'- } \\
\text { GAAAACCAATTTACTCGTCATCGCCGTAGTTTGCTTGAATGGC } \\
\text { TAACGAGGCATTG -3' }\end{array}$ \\
\hline hmbC down frw & 5'- GGCGATGACGAGTAAATTGGTTTTC -3' \\
\hline hmbC down rev & 5'- TAATCTGCTCTTCGATGCCAATTCC -3' \\
\hline hmbC down nested rev & 5'-CATCCGTTGACGAGCCGATGATC -3' \\
\hline \multicolumn{2}{|c|}{ A $h m b C$ gén felszaporítása } \\
\hline hmbC frw & 5’- CAGCCAGCTCAAATCGCTTG -3' \\
\hline hmbC rev & 5'- CAGCAACCTTCTCGCGGTACG -3' \\
\hline
\end{tabular}

\subsection{Bioinformatikai módszerek}

\subsubsection{Lokalizációs szignál azonositása}

A lokalizációs szignálok keresése a http://www.cbs.dtu.dk/services/TargetP/ (Emanuelsson és mtsai. 2000), http://ihg.gsf.de/ihg/mitoprot.html (Claros és Vincens 1996), http://www.peroxisomedb.org/ (Schluter és mtsai. 2010), http://golgi.unmc.edu/ptarget/ Guda és Subramaniam 2005, Guda 2006), http://nls-mapper.iab.keio.ac.jp/cgibin/NLS_Mapper_form.cgi (Kosugi és mtsai. 2009), http://www.genscript.com/psort/wolf_psort.html (Horton és mtsai. 2007), http://genome.unmc.edu/ngLOC/cite.html (King és Guda 2007) weboldalakon található TargetP, Mitoprot, PeroxisomeDB-PTSs Predictor, Ptarget, NLS-mapper, Wolfpsort és ngLOC programok felhasználásával történtek.

\subsubsection{Filogenetikai vizsgálatok}

A HmbB-vel homológ szekvenciák kereséséhez általános (http://blast.ncbi.nlm.nih.gov/Blast.cgi), 

http://www.pombase.org/, $\quad$ http://www.aspgd.org/, $\quad$ http://genome.jgipsf.org/programs/fungi/index.jsf, $\quad$ http://www.candidagenome.org/) adatbázisok is felhasználásra kerültek. A szekvenciaillesztések MAFFT (Katoh és Standley 2013) segítségével, az illesztések megjelenítése doboz-színezéssel a http://www.ch.embnet.org/software/BOX_form.html. weboldal felhasználásával készültek. $\begin{array}{lllll}\text { A szekvenciaillesztések optimalizálása a filogenezishez } & \text { BME } & 1.0\end{array}$ http://mobyle.pasteur.fr/cgi-bin/portal.py\#forms::BMGE (Criscuolo és Gribaldo 2010) szoftver segítségével történt. A "Maximum Likelihood" filogenezis PhyML (Guindon és mtsai. 2010, Dereeper és mtsai. 2008) programmal lett számolva, feltüntetve a megközelítő "likelihood" arányok tesztjeit (Anisimova és Gascuel 2006). A filogenetikai fa megrajzolása a Figtree szoftver (http://tree.bio.ed.ac.uk/software/figtree/) felhasználásával történt.

\subsubsection{Fehérjeszerkezet meghatározása}

A PFAM-keresések a http://pfam.sanger.ac.uk/ oldal felhasználásával történtek. A “Coiled-coil” struktúrák meghatározása a http://toolkit.tuebingen.mpg.de/pcoils weboldalon a Pcoils programmal történt (Parry 1982, Lupas és mtsai. 1991, Lupas 1996). A fehérjeszerkezet modellezését az I-Tasser programmal végeztük a http://zhanglab.ccmb.med.umich.edu/I-TASSER weboldalon (Zhang 2008, Roy és mtsai. 2010), az “ab-initio" modellezést a Quark programmal végeztük a http://zhanglab.ccmb.med.umich.edu/QUARK/ (Xu és Zhang 2012) weboldalon, a modellek renderelését a VMD 1.9. programmal a http://www.ks.uiuc.edu/Research/vmd/ (Humphrey és mtsai. 1996) weboldalon végeztük. A szerkezetek szuperpozíciói a VMD-be integrált MultiSeq segítségével lettek meghatározva (Roberts és mtsai. 2006).

\subsection{Nukleinsav-manipulációhoz felhasznált módszerek}

\subsubsection{Totál DNS kivonása A. nidulans-ból}

$100 \mathrm{ml}$, vitaminoldattal kiegészített folyékony minimál tápoldatban egy éjszakán át nevelt törzsekből nyert micéliumtömeget szüréssel összegyüjtöttük és folyékony nitrogénben történő fagyasztást követően kerámiamozsárban nitrogén alatt eldörzsöltük. Az eldörzsölt micéliumból kb. 0,1 g mennyiséget $0,8 \mathrm{ml}$ LETS pufferrel (0,1 M LiCl, 0,01 M Na 2 EDTA, 0,2 m/v\% SDS, 0,01 M Tris-Cl, pH 7,4) majd 0,8 ml PCI-vel (fenol:kloroform:izoamilalkohol, 25:24:1) mikrocentrifugacsőben vortexeltük, majd 13000 rpm-el 10 percig 
centrifugáltuk. A vizes fázist új mikrocentrifugacsőben azonos mennyiségű kloroformizoamil-alkohol (24:1) eleggyel vortexeltük, majd 13000 rpm-el 10 percig centrifugáltuk. A vizes fázishoz új mikrocentrifugacsőben $10 \%$ (v/v) $3 \mathrm{M}$ Na-acetátot, illetve kétszeres térfogatnyi abszolút etanolt mértünk, majd -20 ${ }^{\circ} \mathrm{C}$-on legalább 20 percig inkubáltuk. Centrifugálás és $70 \%(\mathrm{v} / \mathrm{v})$ etanollal történő mosás után a pelletre desztillált vízzel hígított RNáz-oldatot $(0,05 \mathrm{mg} / \mathrm{ml})$ mértünk és fél órán keresztül $37{ }^{\circ} \mathrm{C}$-on inkubáltuk. Az RNSszennyeződés eltávolítását követően az izolált DNS-t -20 ${ }^{\circ} \mathrm{C}$-on tároltuk.

\subsubsection{RNS kivonása A. nidulans-ból, cDNS szintézise}

Az RNS-tartalom izolálását folyékony nitrogén alatt, kerámiamozsárban púderfinomságúra dörzsölt micéliumokból és konídiumokból végeztük. Erre a célra a NucleoSpin ${ }^{\circledR}$ RNA Plant Kitet (Macherey-Nagel) használtuk a gyártó utasítása szerint. Egyegy kivonáshoz kb. 100 mg biomasszát használtunk fel. Az izolált RNS mennyiségét és minőségét Agilent 2100 bioanalyzer (Agilent Technologies) berendezéssel ellenőriztük. A cDNS-szálakat a RevertAid First Strand cDNA Synthesis Kit (Thermo Scientific) segítségével szintetizáltuk, a gyártó instrukciói szerint. A cDNS szintéziséhez 500 ng templát RNS-t, valamint oligo-dT és random indítószekvenciák 1:1 arányú keverékét használtuk.

\subsubsection{Plazmid minipreparátumok készitése E. coli-ból}

A plazmid DNS izolálását Plasmid Mini Kit (QIAGEN) felhasználásával végeztük, a gyártó utasításai szerint.

\subsubsection{A DNS-minták agaróz gélelektroforézise}

A DNS-minták méret szerinti elválasztását gélelektroforézissel végeztük. Az eljáráshoz $0,8 \mathrm{~m} / \mathrm{v} \%$ agaróz gélt és TAE futtatópuffert (40 mM Tris, $20 \mathrm{mM}$ ecetsav, $1 \mathrm{mM}$ EDTA, pH 7,5) használtunk. A DNS láthatóvá tétele érdekében a gélhez $5 \mu \mathrm{g} / \mathrm{ml}$ etídiumbromidot mértünk. A mintákhoz a futtatás előtt $1 / 5$ térfogatnyi felvivő puffert $(0,5 \mathrm{~m} / \mathrm{v} \%$ SDS; $40 \mathrm{~m} / \mathrm{v} \%$ szacharóz; 0,1 m/v\% brómfenolkék; $50 \mathrm{mM}$ Tris; $10 \mathrm{mM}$ EDTA; pH 7,5) mértünk. Az elektroforézist $75 \mathrm{~V}$ állandó feszültségen végeztük. 


\subsubsection{A DNS visszanyerése agaróz gélböl}

A gélelektroforézist követően a DNS-t tartalmazó sávokat UV fényben vizualizáltuk, majd szikével kivágtuk. A DNS-t a Gel Extraction Kit (Omega bio-tek) felhasználásával tisztítottuk az agaróz gélből a gyártó leírása alapján.

\subsubsection{A DNS emésztése restrikciós endonukleázokkal}

A DNS-minták emésztéséhez tisztított restrikciós enzimeket (Thermo Scientific) használtuk fel a gyártó utasítása szerint.

\subsubsection{A DNS-molekulák ligálása}

A DNS-ligálást T4 ligáz enzimmel végeztük (Thermo Scientific) a hozzá tartozó pufferrel. A vektor:inszert arányt tompa vég esetén 1:8-ra, azonos ragadós vég esetén 1:4-re, különböző ragadós végek esetén pedig 1:1 aránytól 1:4 arányig tetszőleges mértéküre állítottuk be. A reakcióelegyeket $20^{\circ} \mathrm{C}$-on inkubáltuk 16 órán keresztül.

\subsubsection{Polimeráz láncreakció}

Polimeráz láncreakcióhoz a PfuUltra® II Fusion HS DNA Polymerase (Strategene) terméket használtuk a gyártó utasításai szerint. Egy reakció $50 \mu$ l végtérfogatban 100-500 ng templát DNS-t és 50-50 pmol/ $\mu 1$ forward és reverz indítószekvenciákat tartalmazott.

\subsubsection{Kvantitatív valósidejü polimeráz láncreakció (qRT-PCR)}

A 4.6.2. szekció szerint létrehozott cDNS-minták qRT-PCR analízisét CFX96 Real Time PCR System (Biorad) berendezés és SYBR Green/Fluorescein qPCR Master Mix (Thermo Scientific) reakcióelegy felhasználásával végeztük. A $94{ }^{\circ} \mathrm{C}$-on történő 3 perces elődenaturációt 40 ciklus követte az alábbi paraméterekkel: $94{ }^{\circ} \mathrm{C}, 15 \mathrm{sec}, 60{ }^{\circ} \mathrm{C} 60 \mathrm{sec} . \mathrm{Az}$ adatok kiértékelése a „standard curve” eljárással (Larionov és mtsai. 2005) történt. Minden mérés legalább 3 ismétlésben történt.

\subsubsection{Southern-hibridizáció}

Southern-hibridizációhoz a restrikciós endonukleázokkal megemésztett (4.6.6 szekció) 50-50 $\mu \mathrm{g}$ DNS-mintákat agaróz gélelektroforézissel elválasztottuk (4.6.4. szekció), majd kapilláris módszerrel Hybond $\mathrm{N}$ membránra (GE Healthcare) blottoltuk. A jelölt 
próbák előállítását és a detektálást a DIG DNA Labeling and Detection Kit-el (Roche) végeztük a gyártó által megadott protokoll szerint.

\subsection{Kompetens $E$. coli sejtek transzformálása}

A kompentens E. coli XL1-Blue sejteket (Maniatis és mtsai. 1982) jégen kiolvasztottuk. A ligálási elegyet $(7,5 \mu \mathrm{l})$ a kiolvasztott kompetens sejtet tartalmazó mikrocentrifugacsőbe pipettáztuk, majd szuszpendáltuk és 25 percig jégen inkubáltuk. Ezt követően 2 perc $42{ }^{\circ} \mathrm{C}$-os hősokkot alkalmaztunk, majd a mintákat azonnal jégen hütöttük. $800 \mu \mathrm{l}$ LB-oldatot mértünk a mintákra és 45 percig $37{ }^{\circ} \mathrm{C}$-on inkubáltunk. Az inkubáció letelte után $50 \mu$ térfogat transzformáns elegyet ampicillines LB-táptalajra szélesztettünk. A maradékban a sejteket $5000 \mathrm{rpm} 5$ perces centrifugálással összegyüjtöttük, a felülúszót kiöntöttük. A visszamaradt folyadékban felszuszpendált sejteket ampicillines LB-táptalajra szélesztettük. A sejteket egy éjszakán át $37^{\circ} \mathrm{C}$-on inkubáltuk.

\subsection{Az A. nidulans transzformálása}

Az A. nidulans transzformálása Antal és mtsai. (1997) alapján történt celofántenyészeten előállított (Ferenczy és mtsai. 1975, Kevei és Peberdy 1977) protoplasztokkal. A protoplasztképzéshez szilárd komplett táptalajra helyezett celofánra leoltott törzs 16 órás tenyészetét használtuk. A leoltást ecsettel végeztük frissen gyüjtött, 0,01\% (v/v) Tween 80-ban oldott konídiumszuszpenzióval. A protoplasztáláshoz 0,7 M KCl-oldatban feloldott Glucanex enzimkeveréket (Novozyme) használtunk, $400 \mathrm{mg} / 10 \mathrm{ml}$ koncentrációban. A táptalajtól elválasztott celofánokat hármasával steril Petri-csészékbe helyeztük és 6-6 ml protoplasztáló folyadékot pipettáztunk rájuk. A protoplasztálást szobahőmérsékleten végeztük, minimum 1 órán keresztül. A protoplasztokat $100 \mathrm{ml} 0,7 \mathrm{M}$ $\mathrm{KCl}$ oldatban lemostuk a celofánokról. A micéliális szennyeződések sajtszürővel történő eltávolítása után a protoplasztokat 4000 g-vel, $14{ }^{\circ} \mathrm{C}$-on, 25 percen át történő centrifugálással összegyüjtöttük, majd kb. $20 \mathrm{ml} 0,7 \mathrm{M} \mathrm{KCl}$ oldatban mostuk és újra centrifugáltuk. Ezt követően a pelletet felszuszpendáltuk $1 \mathrm{ml} 0,7 \mathrm{M} \mathrm{KCl}$ oldatban. A szuszpenzióból 100-szoros hígítást készítettünk, amelynek protoplaszt-koncentrációját Bürker-kamrával állapítottuk meg. $5-7 \times 10^{7}$ sejtet mikrocentrifugacsőbe mérve lecentrifugáltunk (2500 rpm, 6 perc), majd a pelletet $200 \mu \mathrm{TN} 1$ oldatban $(5,22 \mathrm{~m} / \mathrm{v} \% \mathrm{KCl}$, $0,735 \mathrm{~m} / \mathrm{v} \% \mathrm{CaCl}_{2}$ ) felszuszpendáltuk, majd hozzáadagoltunk 5-10 $\mu \mathrm{g}$ DNS-t és $50 \mu 1 \mathrm{TN} 2$ oldatot (60 m/v\% polietilén-glikol 4000; 1,214 m/v\% Tris; 0,735 m/v\% $\mathrm{CaCl}_{2}$ ). Az elegyet 30 percen át jégen inkubáltuk, majd $1 \mathrm{ml}$ TN2-t mértünk az elegyhez, és 5 percen át jégen 
tartottuk. Ezt követően kb. $20 \mathrm{ml}$ 0,7 M KCl-oldat hozzáadásával egyszer mostuk és centrifugáltuk (4000g, 20 perc) a protoplasztokat, hogy a toxikus PEG-tartalmat eltávolítsuk. A pelletet $1 \mathrm{ml} \mathrm{0,7} \mathrm{M} \mathrm{KCl}$ oldatba szuszpendáltuk és $50 \mathrm{ml}$ max. $42{ }^{\circ} \mathrm{C}$-os szacharózos top agarral $(1 \mathrm{~m} / \mathrm{v} \%) 10 \mathrm{db}$ szacharózos minimál táptalajt tartalmazó csészére öntöttük. A protoplasztokat $37{ }^{\circ} \mathrm{C}$-on regeneráltattuk. Csak azok a protoplasztok tudtak telepet képezni, melyekben a genomba rekombinálódott konstrukción hordozott szelekciós markergén (riboB vagy $p a b a A$ ) kifejeződött és komplementálta a megfelelő auxotrófiát (riboflavin vagy paraamino-benzoesav). A transzformánsokat kiszélesztettük, majd a monoklonális telepekröl konídiumot gyüjtöttünk további felhasználásra.

\subsection{A szubsztitúciós kazetták létrehozása a $h m b A, h m b B$ és $h m b C$ gének deléciójához}

A deléciós mutánsok létrehozásához a „Double Joint PCR” módszer (Yu és mtsai. 2004b) felhasználásával 3 komponensủ deléciós kazettákat készítettünk. PCR segítségével felszaporítottuk az alábbi komponenseket:

A: a deletálni kívánt géntől upstream elhelyezkedő, kb. 3 kbp hosszúságú szekvencia. A $h m b A$ esetében a „hmbA upst frw” és „hmbA upst rev”, $h m b B$ esetében a „hmbB upst frw” és „hmbB upst rev”, hmbC esetében pedig a „hmbC upst frw” és „hmbC upst rev” indítószekvenciákat használtuk (III. táblázat).

B: a transzformációs markerként használt gén, mely komplementálja a recipiens törzs valamely auxotrófiáját. A markergén amplifikálására speciális kiméra primereket használunk: a forward primer 5' vége komplementer az upstream szekvencia nem kódoló szálának 5' végével, a reverse primer 5' vége pedig a downstream szekvencia kódoló szálának 5' végével. A hmbA esetében a „hmbA ribo chim frw” és „hmbA ribo chim rev”, $h m b B$ esetében a „hmbB ribo chim frw” és „hmbB ribo chim rev”, hmbC esetében pedig a „hmbC paba chim frw” és „hmbC paba chim rev” indítószekvenciákat használtuk (III. táblázat).

C: a deletálni kívánt géntől downstream elhelyezkedő, kb. 3 kbp hossúságú szekvencia. A $h m b A$ esetében a „hmbA down frw” és „hmbA down rev”, $h m b B$ esetében a „hmbB down frw” és „hmbB down rev”, $h m b C$ esetében pedig a „hmbC down frw” és „hmbC down rev” indítószekvenciákat használtuk (III. táblázat).

A létrehozott A, B és C komponenseket High Pure PCR Purification Kit (Roche) segítségével tisztítottuk meg a reakcióelegyben maradt indítószekvenciáktól, sóktól és az 
enzimtöl. A komponensek összeszereléséhez egy újabb PCR-t mérünk össze, templátként az A, B és C komponensek 1:2:1 moláris arányú keverékét használva. A hmbA esetében „hmbA upst nested frw” és „hmbA down nested rev”, a $h m b B$ esetében a „hmbB upst nested frw” és „hmbB down nested rev”, a hmbC esetében pedig a „hmbC upst nested frw” és „hmbC down nested rev” indítószekvenciákat használtuk (III. táblázat). A deléciós kazetták létrehozásának folyamatát az 3. ábra foglalja össze. Az összeszerelés hatékonyságát agaróz gélelektroforézis segítségével ellenőriztük, majd a terméket direkt módon felhasználtuk a transzformáláshoz.

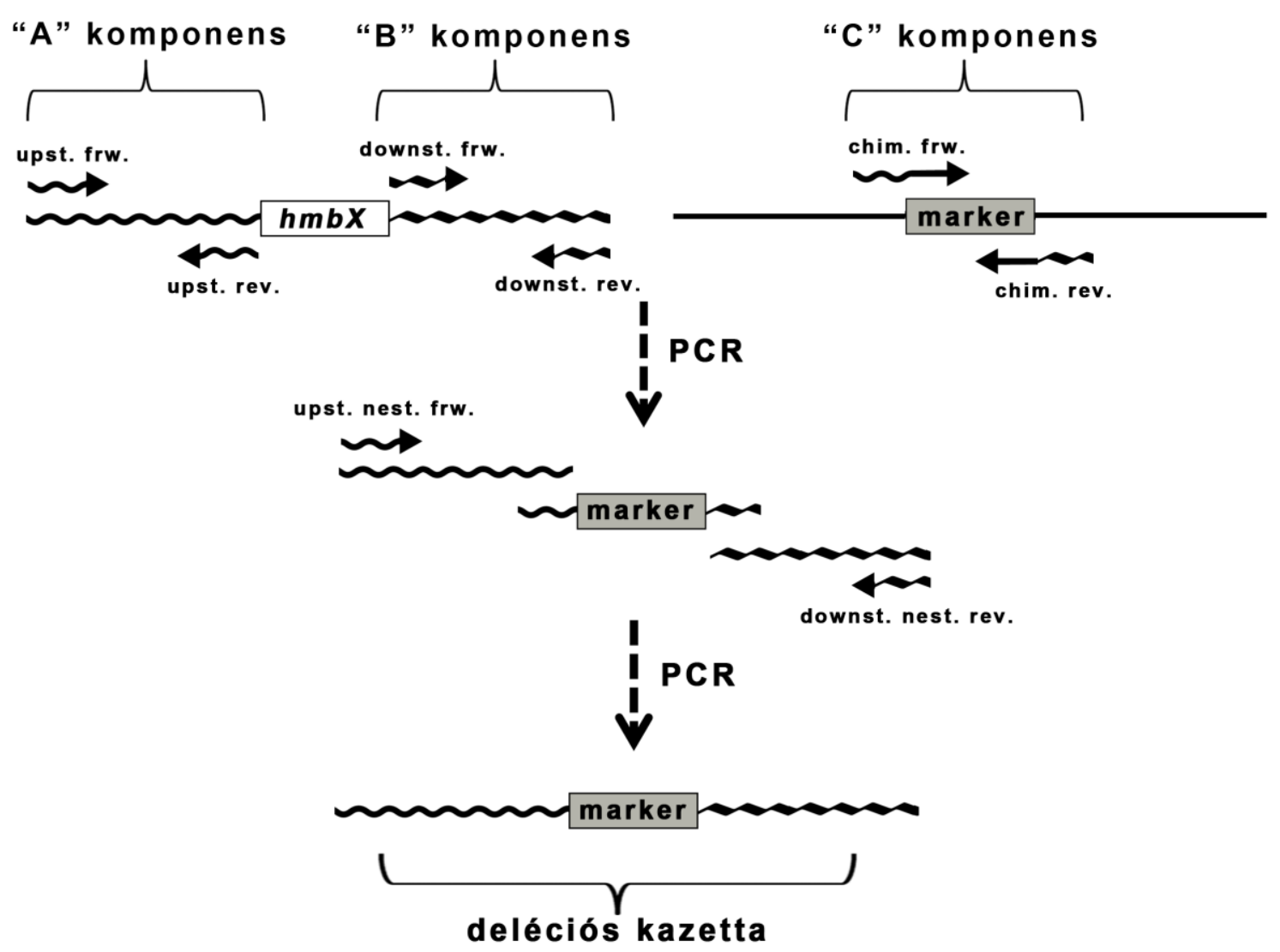

3. ábra: A deléciós kazetták elkészítésének sematikus ábrája. PCR eljárással felszaporítottuk a deletálni kívánt HMG-box fehérjét kódoló géntől $(h m b X)$ upstream irányba eső „A” szakaszt (upst. frw és upst. rev. indítószekvenciák), illetve a downstream irányba eső „B” szakaszt (downst. frw. és downst. rev. indítószekvenciák). Kiméra-indítószekvenciákkal (chim. frw és chim. rev.) szaporítottuk fel a transzformánsok szelekciójához felhasznált marker gént (C komponens). A deléciós kazetta $\mathrm{A}, \mathrm{B}$ és $\mathrm{C}$ komponenseinek összeszerelése egy következő PCR reakcióval történt, az A és B komponensekre specifikus indítószekvencia párral (upst. nest. frw. és downst. nest. rev.). 


\subsection{A $h m b B$ fúziós konstrukciók előállítása}

\subsubsection{A hmbB-gfp-t (C-terminális GFP-fúziós fehérjét) kódoló konstrukció létrehozása}

A GFP-fúziós konstrukció létrehozásához a pAN52-1 plazmidot (Punt és mtsai. 1987) használtuk fel. A vektorba a pantoB szelekciót biztosító markergént beklónoztuk, mely a recipiens törzsben található pantoB2 mutációt képes komplementálni és megszüntetni a törzs pantoténsav auxotrófiáját. A totál DNS templátról felszaporított 2557 bázispár hosszú PCR-terméket (pantoB NdeI frw és pantoB NdeI rev indítószekvenciák), mely a pantoB kódoló szekvencia mellett a gén saját promóterét és terminációs szekvenciáját is hordozta, a pAN52-1 vektor NdeI hasítóhelyére klónoztuk. Az így létrehozott plazmidot pAN-HZS-1nek neveztük el. A létrehozott 9030 bp méretü vektor tartalmazta a pantoB szelekciós marker mellett a $g p d A$ promóter után illesztett GFP-t kódoló szekvenciát és a $\operatorname{trp} C$ gén terminációs szekvenciáját. A GFP-t kódoló szekvencia start kodonja egy NcoI hasítóhelyet tartalmaz (Punt és mtsai. 1987). A HmbB-GFP fúziós fehérje létrehozásához genomi templátról felszaporítottuk a $h m b B$ kódoló szekvenciát (hmbB $N c o$ I frw és hmbB $N c o$ I linker rev indítószekvenciák). A termék tartalmazta a $h m b B$ promóterét is. A PCR-termék mindkét végén egy-egy NcoI hasítóhelyet kódolt, nem tartalmazta a stop kodont, viszont tartalmazott egy 9 aminosav hosszúságú „linker” peptid szekvenciát (LIDTVDLDS). Az így létrehozott szekvenciát a pAN-HZS-1 vektor NcoI hasítóhelyére klónoztuk megfelelő orientációba, létrehozva a pAN-HZS-2 vektort. A vektort templátként felhasználva PCR eljárással felszaporítottuk a HmbB-GFP fúziós fehérjét kódoló régiót (hmbB upst chim frw és pantoB down kim rev indítószekvenciák). A termék tartalmazta a pantoB szelekciós markergént és a trpC terminációs szekvenciát is. A konstrukcióhoz a Double Joint PCR eljárás segítségével a $h m b B$ lókuszt határoló genomi szekvenciákat építettünk a 4.9. fejezetben leírtak szerint. A PCR-termékek előállításához felhasznált indítószekvenciákat a III. táblázatban tüntettük fel.

\subsubsection{A gfp-hmbB-t (N-terminális GFP-fúziós fehérjét) kódoló konstrukció létrehozása}

Felszaporítottuk a $g f p$ szekvenciát az előző pontban bemutatott pAN-HZS-1 vektorról úgy, hogy a szekvencia ne tartalmazza a stop kodont (pGPD int frw és GFP linker chim rev indítószekvenciák). A $h m b B^{+}$törzs DNS-kivonatát templátként használva felszaporítottuk a $h m b B$ gént $(h m b B$ linker chim frw és $h m b B$ down rev 2 indítószekvenciák). Mindkét PCR-termék tartalmazott egy 24 bp hosszúságú, átfedő szekvenciát, mely a fúzió létrehozásához szükséges, és tartalmaz egy 8 aminosav 
hosszúságú linkert (LIDTVDLD) a fúzionált fehérjék közt. A két termék fúzióját PCR segítségével kiviteleztük (GFP NcoI start frw és hmbB N BamHI rev indítószekvenciákkal). A fúziós terméket $N c o$ I és BamHI restrikciós endonukleázokkal emésztettük és $N c o \mathrm{I} / \mathrm{Bam} \mathrm{HI}$ hasítóhelyekre klónoztuk pAN-HZS-1 vektorba. A létrehozott konstrukciót a továbbiakban pAN-HZS-3-nak neveztük. A ,pantoB ${ }^{+} g f p-h m b B$ ” kazettát (GFP fúziója a $h m b B$ kódoló szekvenciával, $\operatorname{trp} C$ terminációs szekvenciával és pantoB szelekciós markerrel) PCR segítségével szaporítottuk fel az „Nterm GFP upst chim frw” és „pantoB hmbB down chim rev" indítószekvenciák felhasználásával. A terméket a $h m b B$ lókuszt határoló szekvenciákkal fúzionáltattuk a C-terminális GFP-fúzió elkészítésénél leírtak szerint. A PCR-termékek előállításához felhasznált indítószekvenciákat a III. táblázatban tüntettük fel.

\subsubsection{A HmbB-His-Tag fúziós fehérjét kódoló konstrukció létrehozása}

A hisztidin-taggelt HmbB fehérje létrehozásához a pAN-HZS-1 vektort használtuk fel. Az expressziós vektort $N c o I / B a m H I$ restrikciós endonukleázokkal emésztettük, és a GFP-t nem tartalmazó vektorrészt agaróz-gélelektroforézist követően visszaizoláltuk. Ebbe a vektorkonstrukcióba klónoztuk a genomi DNS-kivonatról felszaporított, 1120 bp méretü, $h m b B$ kódoló szekvenciát. A forward és reverse indítószekvenciák NcoI, illetve BamHI hasítóhelyet tartalmaztak (hmbB NcoI frw és hmbB HisTag BamHI rev indítószekvenciák). A reverse indítószekvencia a stop kodon előtt 6 darab hisztidin aminosavat is kódolt. A létrehozott HmbB-His-Tag expressziós vektort a továbbiakban pAN-HZS-4-nek nevezzük. A PCR-termékek előállításához felhasznált indítószekvenciákat a III. táblázatban tüntettük fel.

\subsection{Analitikai módszerek}

\subsubsection{A konídiumok cukor-és polialkohol-tartalmának GC-MS analizise}

3 napig CM-táptalajon nevelt $h m b B \Delta$ és $h m b B^{+}$kolóniákról származó $100 \mathrm{mg}$ konídiumot $500 \mu 15 \mathrm{~m} / \mathrm{v} \%$ TCA (triklórecetsav) oldatban extraháltunk 30 percig, $80{ }^{\circ} \mathrm{C}$-on. A felülúszót centrifugálással választottuk el a szilárd fázistól, majd liofilizáltuk. A minták előkészítése és cukorspektrumának analízise a Fiehn-eljárással történt (Fiehn 2006). Az elválasztás HP-5MSI $50 \mathrm{~m} \times 0.25 \mathrm{~mm} \times 0.25 \mu \mathrm{m}$ oszlopon (Agilent, Palo Alto, USA) történt 7890A gázkromatográffal (Agilent, Palo Alto, USA) mely egy 5975C MS készülékhez (Agilent, Palo Alto, USA) volt kapcsolva. A befecskendezési térfogat $1 \mu$ volt porlasztó módban, a porlasztás aránya 100:1 volt. Az áramlási sebesség $20 \mathrm{ml}$ percenként. A kezdeti 
hőmérséklet $80^{\circ} \mathrm{C}$ volt 2 percig, mely percenként $5^{\circ} \mathrm{C}$-al emelkedett $320^{\circ} \mathrm{C}$-ig, majd ezen az értéken maradt 5 percig. Az ionizációhoz felhasznált elektronforrás $70 \mathrm{eV}$ ionizációs energiára lett beállítva. Az ionforrás és az analizátor hőmérséklete $230^{\circ} \mathrm{C}$ és $150{ }^{\circ} \mathrm{C}$ volt. A létrehozott ionokat 50-500 amu (Atomic Mass Unit) sávban vizsgáltuk. A berendezés irányításához és az adatok analíziséhez a MSD ChemStation E.02.00.493 szoftvert (Agilent, Palo Alto, USA) használtuk. Minden mérés legalább 3 ismétlésben történt. A méréseket a Fumoprep Kft. (Magyarország) végezte.

\subsubsection{A Sterigmatocisztin vékonyréteg-kromatográfiás vizsgálata}

7 napig napig CM-táptalajon nevelt kolóniákból $10 \mathrm{~mm}$ átmérőjü dugófúróval 3-3 agarkorongot vágtunk ki, majd azt 50-50 ml kloroformmal extraháltuk. Az extraktumokat 65 ${ }^{\circ} \mathrm{C}$-on történő melegítéssel $1 \mathrm{ml}$ térfogatra koncentráltuk. A mintákat Kieselgel 60 (Merck) vékonyrétegre vittük fel és toluol:etil-acetát:ecetsav (8:1:1) eleggyel futtattuk. A vékonyréteget $15 \mathrm{~m} / \mathrm{v} \% \quad \mathrm{AlCl}_{3}$ etanolos oldatával fújtuk le, majd $100{ }^{\circ} \mathrm{C}$-on, 10 percig inkubáltuk. A másodlagos metabolitokat UV-fénnyel történő megvilágítással vizualizáltuk. A sterigmatocisztin azonosítása standard (Sigma) segítségével történt.

\subsubsection{A trehalóz vékonyréteg-kromatográfiás vizsgálata}

Nyugvó konídiumokból $\left(10^{7} \mathrm{db}\right)$ és 24 órás MM folyadékkultúrában felnövesztett micéliumokból (0,5 g száraztömeg) a cukrokat $2 \mathrm{ml}$ és $10 \mathrm{ml} 5 \mathrm{~m} / \mathrm{v} \%$ TCA (triklór-ecetsav) oldattal extraháltuk $80{ }^{\circ} \mathrm{C}$-on, egy órán át. Az extraktumokat liofilizálással $1 \mathrm{ml}$ végtérfogatra töményítettük be, majd abból 15-15 $\mu$ l térfogatokat Kieselgel 60 (Merck) vékonyréteg felületére vittünk fel. A futtatást kloroform:metanol:víz:ecetsav (55:33:8:1) eleggyel végeztük. A cukrok detektálásához a vékonyréteget fenol-kénsav reagenssel (3 g fenol $+5 \mathrm{ml}$ kénsav $+95 \mathrm{ml}$ etanol) fújtuk le, majd $100{ }^{\circ} \mathrm{C}$-on, 10 percig inkubáltuk. A trehalóz azonosítása standard (Fluka) felhasználásával történ.

\subsection{Mikroszkópos vizsgálatok}

A mikroszkópos preparátumok készítéséhez $10^{4}$ konídiumot oltottunk MM tápoldatba süllyesztett fedőlemez felületére és $37^{\circ} \mathrm{C}$-on inkubáltuk 3-24 órán keresztül. A sejtmagok festéséhez DAPI (4',6-diamidino-2-fenilindol) festéket használtunk May szerint (May 1989) és a preparátumokat fluoreszcens mikroszkóppal vizsgáltuk (Zeiss Axiolab A, Zeiss szürő szett 49). A konídiospórák metabolikus aktivitását MTT [3-(4,5-dimetiltiazol-2il)-2,5-difeniltetrazolium bromid] festéssel mutattuk ki. A $h m b B \Delta$ és $h m b B^{+}$törzsek 
ivartalan spóráit 3-24 óráig csíráztattuk, majd 0,7 M KCl-ban oldott $5 \mathrm{mM}$ MTT festékkel kezeltük 30 percen át. Negatív kontrollként hővel elölt $\left(100{ }^{\circ} \mathrm{C}, 20\right.$ perc $)$ spórákat használtunk. A mitokondriumok láthatóvá tételéhez a mintákat 20 nM MitoTracker Red FM (Invitrogen) festékkel inkubáltuk $37{ }^{\circ} \mathrm{C}$-on, 30 percig, majd fluoreszcens mikroszkóppal vizsgáltuk (Zeiss Axiolab A, Zeiss szűrő szett 09). A GFP és RFP fehérjéket kifejező mintákat „Zeiss szürő szett 15” és „Zeiss szürő szett 09” szürők felhasználásával vizsgáltuk, Axiolab A (Zeiss) fluoreszcens mikroszkóppal.

\subsection{Redox enzimek aktivitásának mérése}

\subsubsection{Fehérjekivonatok készitése}

Fehérjekivonat készítéséhez minimál tápoldatban 3 vagy 36 órán át növesztett biomasszát szürtünk le. Erre 36 órás tenyészetek esetén „cheese-filter”-t, izotropikus növekedési fázisban lévő spórák esetén $0,45 \mu \mathrm{m}$ pórusméretű membránszűrőt használtunk. A leszürt biomasszát egyszer mostuk fehérje-mintapufferrel $\left(0,5 \mathrm{~m} / \mathrm{v} \% \mathrm{KH}_{2} \mathrm{PO}_{4}, 1 \mathrm{~m} / \mathrm{v} \%\right.$ $\mathrm{K}_{2} \mathrm{HPO}_{4}$ desztillált vízben). A mosást követően a mintát folyékony nitrogénnel lefagyasztottuk és kerámiamozsárban liszt finomságúra porítottuk (spórák esetében a feltárást üvegpor hozzáadásával segítettük). A mintákat ezt követően folyamatosan jégen tartottuk. A porított minták fehérjetartalmát 1,5 mM PMSF-el (fenil-metil-szulfonil-fluorid) kiegészített minta-pufferel extraháltuk. Kb. 0,5 g mintához $1 \mathrm{ml}$ puffert mértünk, majd intenzív vortexelést követően a szilárd fázist centrifugálással ülepítettük (15000 g, 5 perc, 4 ${ }^{\circ} \mathrm{C}$ ). A felülúszót új centrifugacsőbe pipettáztuk és ebből végeztük az enzimaktivitás és fehérjetartalom mérését.

\subsubsection{Minták fehérjetartalmának meghatározása (Bradford 1976)}

A minták fehérjetartalmát Bradford-reagens felhasználásával határoztuk meg. A Bradford-reagenst (Sigma, B6916) bidesztillált vízzel kétszeresére hígítottuk. A hígított reagensből 200-200 $\mu 1$ mennyiségeket pipettáztunk 96 lyukú mikrotiter lapra. A reagenshez 5-5 $\mu 1$ mennyiségeket pipettáztunk a mintából, illetve a kalibráláshoz használt BSA (borjú vérsavó albumin) hígítási sorból. Egy-egy mérést három párhuzamosban végeztünk el. A BSA hígítási sort $250 ; 125 ; 62,5 ; 31,25 ; 15,6$ és 7,8 $\mu \mathrm{g} / \mathrm{ml}$ koncentrációkban készítettük el fehérje-mintapufferben. Mérésnél a vizsgált mintákat addig hígítottuk, amíg koncentrációjuk a BSA kalibráció koncentráció-tartományába esett. Minden mérés legalább 3 ismétlésben történt. 


\subsubsection{Glutation-reduktáz (GR) mérése (Pinto és mtsai. 1984)}

A méréshez 4.13.1. fejezetben leírtak szerint elkészített fehérjekivonatot használtunk. A méréshez felhasznált oldatok elkészítéséhez foszfát-puffert $\left(1,6 \mathrm{~m} / \mathrm{v} \% \quad \mathrm{~K}_{2} \mathrm{HPO}_{4} ; 0,08\right.$ $\mathrm{m} / \mathrm{v} \% \mathrm{KH}_{2} \mathrm{PO}_{4} ; \mathrm{pH} 7,6$ ) használtunk. A reakciót az alábbiak szerint mértük össze:

$100 \mu 1$ NADPH-oldat $(0,8 \mathrm{mg} / \mathrm{ml}$ NADPH foszfát-pufferben $)+650 \mu 1$ foszfát-puffer +150 $\mu 1$ GSSG-oldat (6,2 mg/ml GSSG foszfát-pufferben) $+100 \mu 1$ fehérjekivonat.

A reakciót fotometriásan követtük nyomon 1 percig, $340 \mathrm{~nm}$ hullámhosszon. Az 1 perc alatt mért abszorbanciaváltozásból számítottuk ki a GR enzimaktivitást:

aktivitás $=\Delta \mathrm{A} /\left(\mathrm{d} \times \varepsilon_{\varepsilon} \times \mathrm{c}_{\text {prot }} \times \Delta \mathrm{V}\right)$

ahol $\Delta \mathrm{A}$ az 1 perc alatt mért abszorbanciaváltozás, $\mathrm{d}$ a fényút $(1 \mathrm{~cm}), \varepsilon$ a moláris extinkciós koefficiens ( $\left.\mathcal{N}_{\mathrm{NADPH}}, 340 \mathrm{~nm}: 6,3 \times 10^{6} \mathrm{~cm}^{3}(\mathrm{~mol} \mathrm{~cm})^{-1}\right), \mathrm{c}_{\text {prot }}$ a minta fehérjetartalma és $\Delta \mathrm{V}$ a minta hígulásának mértéke. Minden mérés legalább 3 ismétlésben történt.

\subsubsection{Glutation peroxidáz (GPx) mérése (Chiu és mtsai. 1976)}

A méréshez 4.13.1. fejezetben leírtak szerint elkészített fehérjekivonatot használtunk. A méréshez felhasznált oldatok elkészítéséhez Tris/ $\mathrm{HCl}$ puffert (50 mM Tris/ $\mathrm{HCl} ; 0,091$ mM EDTA; pH 7,6) használtunk. A reakciót az alábbiak szerint mértük össze:

$120 \mu 1 \mathrm{NADPH}$-oldat $(0,8 \mathrm{mg} / \mathrm{ml}$ NADPH Tris/HCl pufferben $)+400 \mu \mathrm{l}$ Tris/HCl puffer + $20 \mu \mathrm{l}$ GR-oldat (10-szeresen hígított pékélesztő glutation reduktáz, Sigma) $+250 \mu \mathrm{l} \mathrm{GSH}$ oldat $(0,33 \mathrm{mg} / \mathrm{ml}$ pufferben $)+200 \mu$ f fehérjekivonat $+20 \mu \mathrm{l} \mathrm{CHP-oldat} \mathrm{(pufferrel} \mathrm{550-}$ szeresen hígított kümén hidroperoxid)

A reakciót fotometriásan követtük nyomon 1 percig, $340 \mathrm{~nm}$ hullámhosszon. Az 1 perc alatt mért abszorbanciaváltozásból számítottuk ki a GPx enzimaktivitást a 4.13.3. fejezetben leírtak szerint. Minden mérés legalább 3 ismétlésben történt.

\subsubsection{Glutation-S-transzferáz (GST) mérése (Warholm és mtsai. 1985)}

A méréshez 4.13.1. fejezetben leírtak szerint elkészített fehérjekivonatot használtunk. A méréshez felhasznált oldatok elkészítéséhez foszfát-puffert $\left(1,1 \mathrm{~m} / \mathrm{v} \% \mathrm{KH}_{2} \mathrm{PO}_{4} ; 1 \mathrm{mM}\right.$ EDTA; pH 6,5) használtunk. A reakciót az alábbiak szerint mértük össze: 
$50 \mu \mathrm{CDNB}(6,67 \mathrm{mg} / \mathrm{ml}$ 1-klór-2,4-dinitrobenzol etanolban $)+850 \mu$ puffer $+50 \mu 1$ fehérjekivonat $+50 \mu \mathrm{l} \mathrm{GSH-oldat} \mathrm{(6} \mathrm{mg/ml} \mathrm{glutation} \mathrm{desztillált} \mathrm{vízben)}$

A reakciót fotometriásan követtük nyomon 1 percig, $340 \mathrm{~nm}$ hullámhosszon. Az 1 perc alatt mért abszorbanciaváltozásból számítottuk ki a GST enzimaktivitást:

aktivitás $=\Delta \mathrm{A} /\left(\mathrm{d} \times \varepsilon_{\varepsilon} \times \mathrm{c}_{\text {prot }} \times \Delta \mathrm{V}\right)$

ahol $\Delta \mathrm{A}$ az 1 perc alatt mért abszorbanciaváltozás, d a fényút $(1 \mathrm{~cm}), \varepsilon$ a moláris extinkciós koefficiens $\left(\varepsilon_{\mathrm{GS}-\mathrm{DNB}}, 340 \mathrm{~nm}: 9,6 \times 10^{6} \mathrm{~cm}^{3}(\mathrm{~mol} \mathrm{~cm})^{-1}\right), \mathrm{c}_{\text {prot }}$ a minta fehérjetartalma és $\Delta \mathrm{V}$ a minta hígulásának mértéke. Minden mérés legalább 3 ismétlésben történt.

\subsubsection{Glükóz-6-foszfát dehidrogenáz (G6PD) mérése (Emri és mtsai. 1994)}

A méréshez 4.13.1. fejezetben leírtak szerint elkészített fehérjekivonatot használtunk. A méréshez felhasznált oldatok elkészítéséhez HEPES-puffert (20 mM HEPES; pH 7,6) használtunk. A reakciót az alábbiak szerint mértük össze:

$900 \mu \mathrm{l}$ reagens-oldat $\left(30 \mathrm{mM} \mathrm{MgCl}_{2} ; 0,21 \mathrm{mg} / \mathrm{ml}\right.$ glükóz-6-foszfát; $0,5 \mathrm{mg} / \mathrm{ml}$ NADP HEPES-pufferben) $+75 \mu$ 1 HEPES-puffer $+25 \mu 1$ fehérjekivonat

A reakciót fotometriásan követtük nyomon 1 percig, $340 \mathrm{~nm}$ hullámhosszon. Az 1 perc alatt mért abszorbanciaváltozásból számítottuk ki a G6PD enzimaktivitást a 4.13.3. fejezetben leírtak szerint.

\subsubsection{Szuperoxid-dizmutáz (SOD) mérése (Oberley és Spitz 1984)}

A méréshez 4.13.1. fejezetben leírtak szerint elkészített fehérjekivonatot használtunk. A méréshez felhasznált oldatok elkészítéséhez foszfát-puffert $\left(0,82 \mathrm{mv} \% \quad \mathrm{~K}_{2} \mathrm{HPO}_{4} ; 0,44\right.$ $\mathrm{mg} / \mathrm{ml} \quad \mathrm{KH}_{2} \mathrm{PO}_{4} ; 0,533 \mathrm{mg} / \mathrm{ml}$ dietilén-triamin-pentaecetsav (DETAPAC); $\mathrm{pH} \quad 7,8$ ) használtunk. A reakciót az alábbiak szerint mértük össze:

$800 \mu 1$ reagens-oldat $(0,06 \mathrm{mg} / \mathrm{ml}$ nitro blue tetrazólium $(\mathrm{NBT}) ; 0,07 \mathrm{mg} / \mathrm{ml}$ xantin foszfátpufferben) $+100 \mu$ l fehérjekivonat $+50 \mu$ xantin-oxidáz oldat (foszfát-pufferrel 20szorosan kihígított xantin-oxidáz, Sigma)

A reakciót fotometrálással követtük nyomon 1 percig, $560 \mathrm{~nm}$ hullámhosszon. A mintanélküli „vak” reakcióhoz viszonyítva meghatároztuk azokat a mintamennyiségeket, 
amelyek a reakció 50\%-os gátlását eredményezik. Ez alapján számítottuk a minták enzimaktivitását, úgy, hogy 1 egység SOD aktivitás a reakció 50\%-os gátlásának felelt meg.

\subsubsection{Kataláz (CAT) mérése (Roggenkamp mtsai. 1974)}

A méréshez 4.13.1. fejezetben leírtak szerint elkészített fehérjekivonatot használtunk. A méréshez felhasznált oldatok elkészítéséhez HEPES-puffert (20 mM HEPES; pH 7,6) használtunk fel. A reakcióelegyet az alábbiak szerint mértük össze:

$100 \mu \mathrm{l} \mathrm{H}_{2} \mathrm{O}_{2}$-oldat $\left(100 \mathrm{mM} \mathrm{H} \mathrm{H}_{2}\right.$ desztillált vízben $)+880 \mu 1$ HEPES-puffer $+20 \mu \mathrm{l}$ fehérjekivonat

A $\mathrm{H}_{2} \mathrm{O}_{2}$ fogyását fotometrálással követtük nyomon 1 percig, $240 \mathrm{~nm}$ hullámhosszon. Az 1 perc alatt mért abszorbanciaváltozásból számítottuk ki a CAT enzimaktivitást a 4.13.3. fejezetben leírtak szerint $\left(\varepsilon_{\mathrm{H}_{2} \mathrm{O} 2}, 240 \mathrm{~nm}: 4,36 \times 10^{4} \mathrm{~cm}^{3}(\mathrm{~mol} \mathrm{~cm})^{-1}\right)$.

\subsection{Reaktív oxigéngyökök (ROS) és a semlegesítésükben résztvevő metabolitok (oxidált és redukált glutation, NADP és NADPH, összes tiol) mérése}

\subsubsection{Szuperoxid szabadgyökök mérése (Carter és mtsai. 1994)}

A vizsgált folyadékkultúrák 10-10 ml-es mennyiségeit kiegészítettük 10 mM-os, etanolban oldott DHE-festékkel (dihidroetídium), hogy a festék koncentrációja $10 \mu \mathrm{M}$ legyen. A minták szuperoxid-tartalma a nem fluoreszcens DHE-festékkel elreagálva fluoreszcens etídium képződéséhez vezet. A tenyészetet 30 percig, $37{ }^{\circ} \mathrm{C}$ hőmérsékleten rázattuk $180 \mathrm{rpm}$-el. A kezelést követően a biomasszát centrifugálással kiülepítettük (4000 g, 5 perc, $4{ }^{\circ} \mathrm{C}$ ). A pelletet $2 \mathrm{ml} 5 \mathrm{~m} / \mathrm{v} \%$-os szulfoszalicilsav-oldattal extraháltuk 20 percig, a mintákat jégen tartva és 2 percenként vortexelve. Ezt követően a mintákat 4000 g-n 5 percig centrifugáltuk $4{ }^{\circ} \mathrm{C}$-on. A felülúszót új csőbe pipettáztuk és kiegészítettük azonos térfogatú 10×TBE (0,9 M Tris, 0,89 M bórsav, 25 mM EDTA, pH 8) pufferrel. A minták fehérjetartalmát a 4.13.2. pontban leírtak szerint határoztuk meg. A mintákban képződött etídium mennyiségét fluorimetriás eljárással mértük Fluostar Optima (BMG Labtech, Németország) berendezéssel $485 \mathrm{~nm}$ excitációs és $590 \mathrm{~nm}$ emissziós hullámhosszú szürőkkel. A minták 200-200 $\mu$ l-es mennyiségeit 96 lyukú mikrotiterlapra vittük fel. Kalibrációra EtBr-oldatot használtunk az alábbi koncentrációkban: 0,63; 1,25;2,5; 5 és 10 $\mu \mathrm{M}$. A foto-elektron sokszorozó $1500 \times$ erősítésre volt állítva. Számolásnál a minta 
etídiumtartalmát osztottuk a minta fehérjetartalmával. Minden mérés legalább 3 ismétlésben történt.

4.14.2. Diklorofluoreszcein-diacetát (DCFDA)-oxidáló kapacitás mérése (Ezaki és mtsai. 2000)

A minta előkészítése, extrakciója és a fehérjetartalom mérése a szuperoxid szabadgyök mérésénél leírtak szerint zajlott, kivéve, hogy a DHE helyett $10 \mu \mathrm{M}$ DCFDA (10 mM törzsoldat DMSO-ban) festéket használtunk a tenyészetek kezelésénél. A nem fluoreszcens DCFDA észterázos hasítást követően, a reaktív oxigéngyökökkel elreagálva fluoreszcens DCF-é alakul át. A minták DCF-tartalmának mérését szintén Fluostar Optima berendezéssel (BMG Labtech, Németország) végeztük. Kalibrációra FITC-oldatot használtunk 0,$63 ; 1,25 ; 2,5 ; 5$ és $10 \mu \mathrm{M}$ koncentrációkban. A mérés $485 \mathrm{~nm}$ excitációs és $520 \mathrm{~nm}$ emissziós hullámhosszú szűrőkkel történt. A foto-elektron sokszorozót 2000× erősítésen használtuk. Számolásnál a minták DCF tartalmát osztottuk a minta fehérjetartalmával. Minden mérés legalább 3 ismétlésben történt.

\subsubsection{Redukált és oxidált glutation (GSH és GSSG) mérése (Anderson 1995)}

A vizsgált gombatörzseket folyékony nitrogén alatt púder finomságúra dörzsöltük, majd annak körülbelül 1 g-os mennyiségeit $2 \mathrm{ml} 5 \mathrm{~m} / \mathrm{v} \%$ szulfoszalicilsavval extraháltuk 20 percig $4{ }^{\circ} \mathrm{C}$-on. A szilárd fázist $15000 \mathrm{~g} 10$ perces ülepítéssel távolítottuk el. A mintákat ezt követően $500 \mu$ l részletekre osztottuk és 25-25 $\mu$ l trietanolaminnal közömbösítettük. A GSSG mérése esetén a GSH-t $12 \mu 1$ 4-vinilpiridin hozzáadásával közömbösítettük. Reakciópufferként $1,973 \mathrm{~m} / \mathrm{v} \% \mathrm{NaH}_{2} \mathrm{PO}_{4} ; 2,232 \mathrm{~m} / \mathrm{v} \% \quad \mathrm{Na}_{2}$ EDTA oldatot használtunk. A reakcióelegyet az alábbiak szerint mértük össze:

$100 \mu 1$ minta $+800 \mu 1$ NADPH oldat $(0,248 \mathrm{mg} / \mathrm{ml}$ NADPH reakciópufferben $)+100 \mu 1$ DTNB oldat (2 $\mathrm{mg} / \mathrm{ml}$ DTNB reakciópufferben) + $20 \mu$ l glutation reduktáz (élesztő glutation-reduktáz tízszeresére hígítva desztillált vízzel).

A reakciót fotometrálással követtük nyomon, 412 nanométeren mérve, 1 percen keresztül. Standardnak $0 \mu \mathrm{M}, 50 \mu \mathrm{M}$ és $100 \mu \mathrm{M}$ GSH oldatot, illetve $0 \mu \mathrm{M}, 12,5 \mu \mathrm{M}$ és $25 \mu \mathrm{M}$ GSSG oldatot használtunk. Számolásnál a minták GSH és GSSG tartalmát biomassza száraztömegre vonatkoztattuk. Minden mérés legalább 3 ismétlésben történt. 


\subsubsection{NADP és NADPH meghatározása (Tamoi és mtsai. 2005)}

A vizsgált gombatenyészetek nitrogén alatt eldörzsölt biomasszájából megközelítőleg 100 mg mennyiséget extraháltunk $500 \mu$ l etanol:víz (1:1) keverékével 20 percig, $4{ }^{\circ} \mathrm{C}$-on. Az extrakciós puffert NADPH-mérés esetén 0,1 M KOH-al, NADP-mérés esetén 0,1 M HCl-al egészítettük ki. A szilárd fázis centrifugálással történő ülepítése (10000 g, 5 perc) után a felülúszóval dolgoztunk tovább. Reakciópufferként HEPES-puffert (100 mM HEPES-KOH, 0,5 mM EDTA, pH 8) használtunk. A reakcióelegyet az alábbiak szerint mértük össze:

$980 \mu 1$ szubsztrát-oldat $(0,42 \mathrm{mM}$ MTT, 2,5 mM glükóz-6-foszfát, 1,66 mM PMS reakciópufferben oldva $)+10 \mu 1$ minta vagy standard $(0,25,50,100 \mu \mathrm{M}$ NADP $)+10 \mu 1$ enzim-oldat (70 unit/ml glükóz-6-foszfát-dehidrogenáz (Sigma) desztillált vízben oldva)

A reakciót fotometrálással követtük nyomon, 570 nm hullámhosszon, 1 percen keresztül. A meghatározott NADP- és NADPH-mennyiségeket biomassza száraztömegre normalizáltuk. Minden mérés legalább 3 ismétlésben történt.

\subsection{5. Összes tiol mennyiségének meghatározása (Lewinska és Bartosz 2008)}

A minták előkészítése megegyezik a 4.14.3. szekcióban leírtakkal, kivéve, hogy az extrakció $5 \mathrm{ml}, 2,5 \mathrm{~m} / \mathrm{v} \%$ TCA (triklórecetsav) oldatban történik. Reakciópufferként Trispuffert (0,3 M Tris/HCl puffer, $1 \mathrm{mM}$ EDTA, pH 8,2) használtunk A reakcióelegyet az alábbiak szerint mértük össze:

$1800 \mu 1$ reakciópuffer $+200 \mu 1$ minta $+20 \mu 1$ DTNB-oldat $(10 \mathrm{mg} / \mathrm{ml}$ DTNB, $2 \mathrm{~m} / \mathrm{v} \%$ $\left.\mathrm{NaHCO}_{3}\right)$.

A reakciót fotométerrel követtük nyomon, 412 nm hullámhosszon, 10 percig. A számításnál a 0 és 10 percnél mért értékek különbségét használtuk. A tioltartalom számítása az alábbiak szerint történik:

$\mathrm{c}_{\text {tiol }}=\Delta \mathrm{A} /\left(\mathrm{d} \times \varepsilon_{\varepsilon} \times \mathrm{c}_{\text {prot }} \times \Delta \mathrm{V}\right)$

ahol $\Delta \mathrm{A}$ a tíz perc alatt mért abszorbanciaváltozás, $\mathrm{d}$ a fényút $(1 \mathrm{~cm}), \varepsilon$ a moláris extinkciós koefficiens $\left(\varepsilon_{\mathrm{NADPH}}=13,6 \mathrm{mmol}^{-1} \times 1 \times \mathrm{cm}^{-1}\right)$ és $\Delta \mathrm{V}$ a minta hígulásának mértéke. A minták összes tioltartalmát biomassza-száraztömegre normalizáltuk. Minden mérés legalább 3 ismétlésben történt. 


\subsection{Western blot analízis}

A vizsgált törzsek 24 órás MM-tápoldatban nevelt gombafonalait folyékony nitrogén alatt eldörzsöltük és a biomassza $500 \mathrm{mg}$ mennyiségeit $1 \mathrm{ml}$ fehérje-mintapufferrel (4.13.1. fejezet) extraháltuk 10 percig $4{ }^{\circ} \mathrm{C}$-on. A szilárd fázist centrifugálással $(15000 \mathrm{~g}, 15$ perc, 4 ${ }^{\circ} \mathrm{C}$ ) távolítottuk el. A felülúszó fehérjetartalmát 1/10 térfogat TCA (triklórecetsav) hozzáadásával 30 perc $4{ }^{\circ} \mathrm{C}$-on történő inkubációval csaptuk ki. A pelletet $15000 \mathrm{~g} 10$ perc centrifugálással ülepítettük, majd kétszer mostuk $200 \mu$ jéghideg acetonnal. Beszárítás után a pelletet $300 \mu$ l fehérje-mintapufferben oldottuk fel, majd meghatároztuk a fehérjetartalmát (4.13.2. fejezet). $20 \mu \mathrm{g}$ mintamennyiségeket és $10 \mu \mathrm{l}$ fehérje molekulasúlylétrát (ProSieve Quad-Color Protein Molecular Weight Marker, Lonza Rockland) 12\%-os denaturáló poliakrilamid gélen futtattunk meg (Laemmli 1970). A fehérjéket PVDF (polivinilidénfluorid) membránra blottoltuk iBlot száraz blottolórendszer (Invitrogen, USA) segítségével. A GFP detektálását anti-GFP szérum (Clontech) felhasználásával kiviteleztük 1:1000 hígításban. A torma-peroxidázhoz kapcsolt másodlagos antitestet (Thermo Scientific) 1:10000 hígításban alkalmaztuk. A mosásokhoz és az antitestek hígításához TBST-puffert (137 mM NaCl, 2,7 mM KCl, 19 mM Tris-HCl (pH 7,4), 0,1\% (v/v) Tween 20) használtunk. A filter kezelése az alábbiak szerint történt:

1. Blokkolás: A filtert $50 \mathrm{ml}$ TBST $+3 \mathrm{~m} / \mathrm{v} \%$ sovány tejporoldatban inkubáltuk szobahőmérsékleten, 2 órán keresztül.

2. Jelölés elsődleges antitesttel: Az elsődleges antitestet a gyártó által megadott mértékben, $30 \mathrm{ml}$ TBST-pufferben hígítottuk, majd ebben az oldatban a filtert 1,5 órán át, szobahőmérsékleten rázattuk.

3. Mosás: A filtert $3 \times 15$ percig mostuk $50-50 \mathrm{ml}$ TBST-pufferben.

4. Jelölés másodlagos antitesttel: A másodlagos antitestet a gyártó által megadott mértékben, $30 \mathrm{ml}$ TBST-pufferben hígítottuk, majd ebben az oldatban a filtert 1,5 órán át szobahőmérsékleten rázattuk.

A fehérjék detektálását ECL ${ }^{\mathrm{TM}}$ Prime Western Blotting Detection Reagent (GE Healthcare) segítségével végeztük, C-DiGit Chemiluminescent Western Blot Scanner (LICOR) berendezés felhasználásával. 


\subsection{Konídiumok és micéliumból származó protoplasztok oxigénfelvételének meghatározása}

Az oxigénfelvétel mértékét Yu és mtsai. (2004a) által leírt módszerrel végeztük, néhány módosítással. 3 napig $\mathrm{CM}$-táptalajon tenyésztett kolóniákról begyüjtött konídiumokat MM-tápoldatban inkubáltunk $37{ }^{\circ} \mathrm{C}$-on $180 \mathrm{rpm}$ rázatás mellett. A protoplasztokat celofánon nevelt micéliumokból (Ferenczy és mtsai. 1975, Kevei és Peberdy 1977) állítottuk elő 4 m/v\% Glucanex (Novozymes, Svájc) 0,7 M KCl-ban felvett oldatával. Az oxigénfelvételi rátát Respire 1 Clark-típusú oxigénelektróddal (Hansatech, Anglia) követtük nyomon. A mérések $25^{\circ} \mathrm{C}$ hőmérsékleten történtek $1 \mathrm{ml}$ MM-tápoldatban, melyet a protoplasztok esetén $0,7 \mathrm{M} \mathrm{KCl}$-al is kiegészítettünk. A minták $10^{8}$ konídiumot, vagy $10^{7}$ protoplasztot tartalmaztak. Az oxigén mennyiségét 10 percen át mértük. A kalibrációhoz oxigénnel (40 $\mu \mathrm{g} \mathrm{O}_{2} \mathrm{ml}^{-1} 25{ }^{\circ} \mathrm{C}$-on) és nitrogénnel telített $\left(0 \mu \mathrm{g} \mathrm{O} \mathrm{O}_{2} \mathrm{ml}^{-1}\right)$ desztillált vizet használtunk. A minták összes tioltartalmát biomassza-száraztömegre normalizáltuk. Minden mérés legalább 3 ismétlésben történt.

\subsection{Az A. nidulans homo- és heterozigóta keresztezése}

$\mathrm{Az}$ A. nidulans homotallikus gombafaj, így szexuális ciklusra egy-egy törzs önmagában is képes induktív körülmények közt (homozigóta keresztezés). Két különböző genotípusú micélium fúziója esetén heterokariotikus hifa alakul ki. A heterokariotikus micélium esetében indukálva a szexuális ciklust (heterozigóta keresztezés), a kialakuló dikariotikus „crozier” struktúrák azonos vagy különböző genotípusú sejtmagokat tartalmazhatnak. Ennek megfelelően egy-egy termőtestben vagy valamely szülőre jellemző, vagy rekombináns genotípusú aszkospórák képződnek.

\subsubsection{Homozigóta keresztezés}

CM-táptalaj felületére ( $15 \mathrm{ml}$ táptalaj, d=60 mm-es Petri-csésze 5 pontba oltottuk a vizsgált törzs spóraszuszpenzióját fogpiszkáló segítségével. A tenyészetet 3 napig inkubáltuk $37{ }^{\circ} \mathrm{C}$-on. Ezt követően a Petri-csészék peremét cellux szalaggal lezártuk annak érdekében, hogy oxigénhiányos környezet kialakításával indukáljuk a szexuális ciklus elindulását. A csészéket további 2-3 hétig inkubáltuk $37{ }^{\circ} \mathrm{C}$-on, az érett termőtestek megjelenéséig. A termőtesteket MM-táptalaj felületén sztereomikroszkóp alatt fogpiszkálóval görgetve megtisztítottuk a hifák és az ivartalan spórák okozta szennyezéstöl. 1-1 termőtestet 200-200 $\mu 1$ 0,01 m/v\%-os Tween 80 oldatban törtünk össze (a termőtestet a 
pipettahegy csúcsával a mikrocentrifuga cső falához nyomva) és felszuszpendáltuk. A szuszpenziókat későbbi felhasználásig $4{ }^{\circ} \mathrm{C}$-on tároltuk.

\subsubsection{Heterozigóta keresztezés}

A keresztezés céljára két olyan törzset választottunk ki, melyek legalább 1 olyan auxotrófiát okozó mutációt hordoznak, ami csak az egyik partner törzsben található meg. A leoltáshoz CM-táptalajt használtunk (15 ml táptalaj, d=60 mm-es Petri-csésze), amely mindkét törzs növekedését lehetővé tette. A két törzset spóraszuszpenzióból sakktáblaszerüen pontba oltottuk a táptalajra. A tenyészetet $37{ }^{\circ} \mathrm{C}$-on inkubáltuk 3 napig, majd szike segítségével 5 darab agarkockát (kb. $2 \mathrm{~mm}$ x $4 \mathrm{~mm})$ vágtunk ki a tenyészetek azon részeiböl, ahol a két törzs telepszélei összeértek. Az agarkockákat MM-táptalaj (20 ml táptalaj, d=60 mm-es Petri-csésze) felületére helyeztük a hifát tartalmazó felülettel lefelé. Ezen a táptalajon növekedni csak a szülői törzsek hifáinak fúziójával létrejövő heterokariotikus gombafonal tud. A tenyészetet $37{ }^{\circ} \mathrm{C}$-on inkubáltuk 3 napig. A szexuális ciklus indukálása és a termőtestek legyüjtése megegyezik a homozigóta keresztezésnél leírtaknál. A termőtestekből készült $200 \mu$ szuszpenzió 5-5 $\mu$ l-es mennyiségét steril fogpiszkálóval MM-táptalaj felületére szélesztettük. Ezen a táptalajon csak a rekombináns prototróf aszkospórák tudnak nőni, ezért minden termőtest esetében meg tudtuk állapítani, hogy rekombináns vagy szülői termőtestet gyüjtöttünk. A rekombináns aszkospóraszuszpenziókból 2,5; 5; 10; $15 \mu 1$ térfogatokat CM-táptalajra szélesztettünk. 2 nap, $37{ }^{\circ} \mathrm{C}$-on történő inkubálást követően az egyedi telepekből spóraszuszpenziót készítettünk, és a vizsgálati célnak megfelelő összetételü táptalajokon utódanalízist végeztünk.

\subsection{A spórák kolóniaképző képességének vizsgálata}

Ivaros vagy ivartalan spórákból, $0,01 \mathrm{~m} / \mathrm{v} \%$ Tween 80-ban készült szuszpenzió spóraszámát Bürker-kamra segítségével állapítottuk meg. A szuszpenziókból hígítást készítettünk úgy, hogy a $h m b B \Delta$ törzs esetében $4 \times 10^{6}$, a többi törzs esetében $4 \times 10^{3}$ spóra legyen a szuszpenzió $1 \mathrm{ml}$ térfogatában. A szuszpenziók $25 \mu \mathrm{l}$ mennyiségeit 3-3 CMtáptalajt tartalmazó Petri-csésze felületére szélesztettük (100-100 spóra a $h m b B^{+}$esetében, a hmbB $\triangle$ törzsnél pedig 1000-1000 spóra kerül egy csészére). $37^{\circ} \mathrm{C}$-on inkubáltuk a csészéket a telepek megjelenéséig. A telepeket megszámoltuk, majd az egyes csészéken kapott értékeket átlagoltuk. A kolóniaképző képességet a 100 spórára vonatkoztatott kolóniaszámmal jellemeztük. Minden mérés legalább 3 ismétlésben történt. 


\subsection{A gombakolóniák növekedési rátájának vizsgálata}

3 napos MM-táptalajon nevelt kolóniák konídium-mentes pereméből $3 \mathrm{~mm}$ átmérőjü korongokat vágtunk ki dugófúróval. A korongokat a hifát tartalmazó felületükkel lefelé MM-táptalaj felületére helyeztük. A tenyészeteket 37 , vagy $42{ }^{\circ} \mathrm{C}$-on inkubáltuk. A kolóniák sugarát a második naptól kezdve mértük 24 óránként. A növekedési rátát a kontrollra vonatkoztatott, százalékos értékben fejeztük ki. A kísérleteket legalább 3 ismétlésben elvégeztük.

\subsection{Statisztikai analízishez felhasznált módszerek}

Az adatok statisztikai kiértékeléséhez a GraphPad Prism 5 szoftver demo verzióját (GraphPad Prism version 5.0 for Windows, GraphPad Software, La Jolla California USA, www.graphpad.com) használtuk. A szignifikanciák meghatározását „one way ANOVA” módszerrel végeztük. 


\section{EREDMÉNYEK}

\subsection{HMG-box fehérjék $A$. nidulans-ban}

\subsubsection{Kromatinkapcsolt HMG-box fehérjék azonositása A. nidulans-ban}

In silico (BLAST) vizsgálattal az A. nidulans genomjában hét HMG-box domén fehérjét kódoló gént találtunk (Függelék II.). A HMG-box domént tartalmazó fehérjék kereséséhez a humán HMGB1 fehérje HMG-box doménjének szekvenciáját használtuk. Ezek a gének az AN2885, AN1267, AN10103, AN3667, AN4734, AN3549 és AN1962 fehérjéket kódolják, melyek közül csak az AN4734 ismert, mint a MatA (MAT2) párosodási típust meghatározó protein (Paoletti és mtsai. 2007, Pyrzak és mtsai. 2008, Czaja és mtsai. 2011). A többi fehérjéről nincsenek ismereteink, azonban az alapján, hogy a HMG-box domén második $\alpha$-hélixét megelőző aminosav poláros vagy apoláros, nagy biztonsággal megjósolható, hogy a fehérje szekvencia-specifikusan vagy szekvencia-aspecifikusan kötődik a kromatikus DNS-hez (Malarkey és Churchill 2012). Amennyiben ez az aminosav poláros, a fehérje DNS-specifikus kötődést fog mutatni (Malarkey és Churchill 2012). Poláros aminosav található a nevezett pozícióban a MatA (AN4734, Asn), AN1962 (Asn), AN3549 (Lys) és az AN3667 (His) esetében, és apoláros aminosav az AN2885 (Phe), AN1267 (Val) és az AN10103 (Pro) fehérjék esetében (csillaggal jelzett aminosavak a Függelék II.-ben). Ennek alapján úgy tünik, hogy az AN1962, AN3549, AN3667 és az ismert AN4734 (MatA) gének vélhetőleg transzkripciós faktorokat kódolnak, míg az AN2885, AN1267 és AN10103 gének által kódolt fehérjék általános DNS-kötő funkcióval bírnak és valószínűleg architektúrális szerepet töltenek be a kromatinban. Az utóbbi három fehérjét $\mathrm{HmbA}, \mathrm{HmbB}$ és HmbC-nek, a fehérjéket kódoló géneket pedig $h m b A, h m b B$ és $h m b C$-nek neveztük el az $A$. nidulans elfogadott nevezéktanának megfelelően. Az azonosított fehérjék néhány fontosabb paraméterét az IV. táblázatban foglaltuk össze.

IV. táblázat: A HmbA, HmbB és HmbC fehérjék néhány fontosabb tulajdonsága.

\begin{tabular}{|r|c|c|c|}
\hline Fehérje: & HmbA & HmbB & HmbC \\
\hline Hosszúság (aminosav) & 106 & 326 & 297 \\
\hline Molekulatömeg (kDa) & 12 & 36,8 & 33 \\
\hline Intronok száma & 5 & 2 & 2 \\
\hline Izoelektromos pont & 9,82 & 10,84 & 5,49 \\
\hline Konzervált HMG-box domének & 1 & 1 & 2 \\
száma & 1 & &
\end{tabular}




\subsection{2. $\mathrm{HmbA}$}

Az AN2885 (HmbA) egy rövid fehérjét kódol, melyben csak egy HMG-box található a S. cerevisiae-ban leírt Nhp6A és Nhp6B redundáns fehérjepárhoz hasonlóan, melyek architektúrális szerepet töltenek be az élesztő kromatin szerveződésében. Az nhp6A/B dupla deléciós mutánsokban sérült a Pol-II és Pol-III által katalizált transzkripció és pleiotróp mutáns fenotípus alakul ki. A sejtek nem tudják a galaktózt szénforrásként hasznosítani, rezisztensek hidrogén-peroxiddal és UV-besugárzással szemben, érzékenyek a nitrogénéhezésre és hőmérsékletérzékeny morfológiai elváltozásokat mutatnak, mint pl. megnyúlt sarjsejtek, amelyek 1 M szorbitollal kúrálhatóak (Kolodrubetz és Burgum 1990, Stillman 2010).

\subsection{3. $\mathrm{HmbB}$}

5.1.3.1. A HmbB feltételezhető mitokondriális lokalizációja, doménszerkezete és összehasonlítása más mitokondriális HMG-box fehérjékkel

A HmbB és ortológjai közül a $P$. anserina mtHMG1 fehérje vizsgálataink alapján valószínűleg tartalmaz egy mitokondriális pre-peptidet az N-terminálison (4. ábra, fekete háromszögek jelzik a prepeptid hasítási helyét, a háromszögtől az amino-vég felé eső szekvenciák a lokalizációs szignál szekvenciák). A HmbB és a $P$. anserina mtHMG1 fehérjék molekulamodellezése alapján fényt derítettünk arra, hogy az általános HMG-box doménen kívül további két HMG-box domént hordoznak, melyek AS-szekvencia alapján nem azonosíthatóak HMG-box doménnek (5. ábra), de a térbeli szerkezetük nagy megbízhatósággal illeszkedik az emlős Tfam fehérjék általános HMG-box doménjéhez, ezért nagy valószínűséggel HMG-box doménnek tekinthetőek (4. ábra $\mathrm{B}$ és $\mathrm{C}$ ablak). A továbbiakban ezt a két, N-terminális régióban elhelyezkedő domént „Shadow-HMG-box”nak (ShHMG-B) nevezzük. Néhány fehérje (köztük a $\mathrm{HmbB}$ is) tartalmaz sejtmagi transzportot eredményező motívumot a szekvenciavizsgálat alapján (Karácsony és mtsai. 2014). A HmbB fehérje esetében ez a motívum egy kettéosztott szignálszekvencia a 94-108 és 121-135 pozíciójú aminosavaknál az első ShHMG-box domén C-terminális régiójában. A mitokondriális és sejtmagi transzportot eredményező motívumok együttes megléte azt sugallja, hogy a HmbB fehérje mind a mitokondriumban, mind a sejtmagban képes szerepét betölteni. 
A

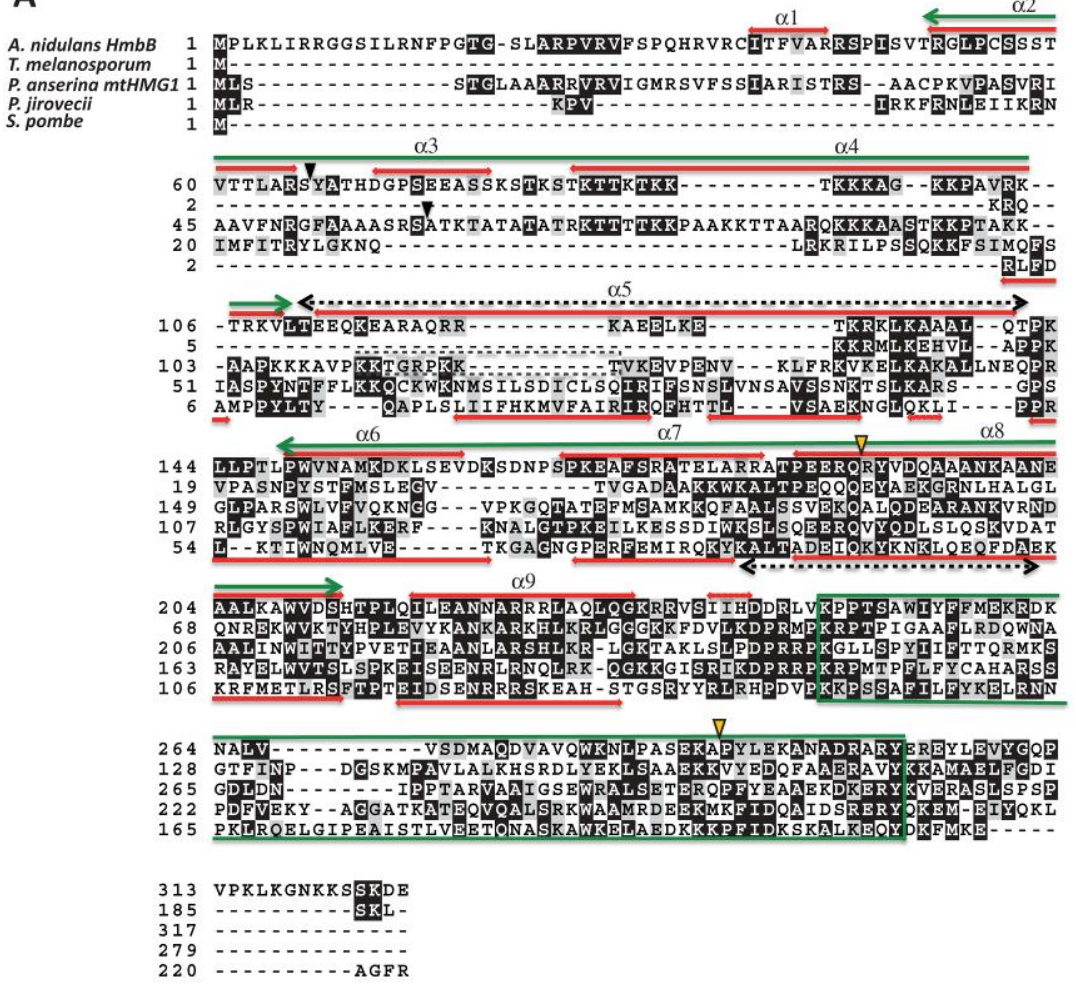

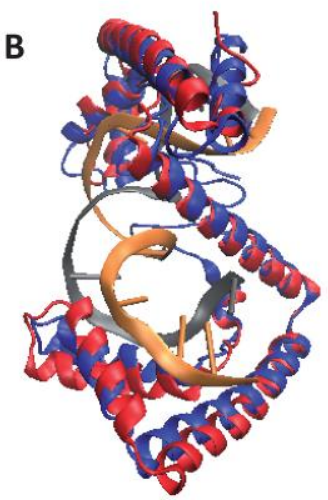

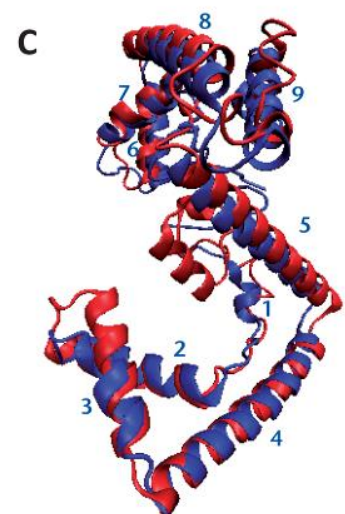

4. ábra: Az A. nidulans HmbB és valószínüsíthető ortológjainak szekvenciaillesztése, valamint a HmbB és mtHMG1 fehérjék molekulamodellje. A: A szekvenciaillesztés a HmbB szekvenciája mellett a Pezizomycotina csoportban található valószínüsíthető ortológokat (T. melanosporum Tubeme1_946, $P$. anserina mtHMG1) és a

Taphrinomycotina csoportban talált 2 homológot (P. jirovecii Pnji_1073, S. pombe Schp_954) tartalmazza. A

zöld doboz az összes homológban megtalálható kanonikus HMG-box domént jelöli. Az A. nidulans és $S$. pombe szekvenciák esetén valószínüsített $\alpha$-hélix struktúrákat vörös színű kettős nyilak jelölik. A rövid 3-10 hélixeket (3 oldallánc) hasonlóan jelöltük, de nem számoztuk. A HmbB szekvencia feletti zöld kettős nyilak a valószínüsíthető Shadow-HMG-boxokat jelölik. A szaggatott fekete kettős nyilak valószínüsíthető coiled-coil struktúrákat jelölnek. A $P$. anserina mtHMG1 szekvencia valószínüsíthető AT-hurok struktúráját szaggatott fekete téglalap határolja. A HmbB valószínüsíthető $\alpha$-hélixeit $(\alpha 1-\alpha 9)$ a vörös nyilak felett számoztuk meg. A

fekete háromszögek a mitokondriális pre-peptid valószínü hasítási helyét jelölik. A sárga háromszögek a

Pneumocystis és a Pezizomycotina által alkotott klád (3.ábra) konzervált intronjait jelölik. Mindkét intron konzervált $P$. jirovecii-ben, de a Pezizomycotina legtöbb tagjától eltérően csak a C-terminális intron konzervált $P$. anserina-ban. Mindkét intron hiányzik a $S$. pombe homológban. B: A HmbB N-terminálisának 3D modellje (kék) a kezdő metionintól a kanonikus HMG-boxot megelőző valinig és annak illesztése a humán Tfam (vörös) szerkezetére. A doménekhez kötődő DNS (szürke és narancs) illeszkedése is fel van tüntetve. C: A HmbB Nterminális 3D modelljének (kék) illesztése a $P$. anserina mtHMG1 (vörös, a kezdő metionintól a kanonikus HMG-boxot megelőző prolinig) 3D modelljére. A számozás megfelel az A ábrán bemutatott $\alpha$-hélixeknek.

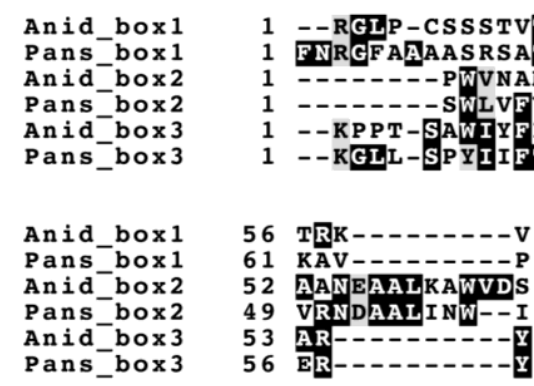

5. ábra: A HmbB fehérje Shadow-HMG-boxok (Anid) és az mtHMG1 (Pans) szekvenciaillesztése. Az 1 és 2 boxok az amino és karboxi Shadow-HMG-boxok. A 3-as box a kanonikus HMG-box mindkét fehérje esetében.

A Shadow-HMG-boxok határait a 4. ábrán bemutatott modellek alapján határoztuk meg.

Az 5.1.3.2. fejezetben, a 6. ábrán feltüntetett filogenetikai vizsgálat eredményei, valamint a meglévő intronok pozícionálódásának abszolút konzerváltsága alapján (Függelék 
III) megállapítottuk, hogy a Pneumocystis fajok és a Pezizomycotina csoport HmbB-vel ortológ fehérjéi egy monofiletikus kládot alkotnak, egymás ortológjai.

\subsubsection{A HmbB filogenetikai analízise}

Bioinformatikai vizsgálatot végeztünk 32, az Ascomycota-k különböző rendjeibe tartozó fajok genom-adatbázisaiban azonosított, valószínüsíthető HmbB homológokkal és az ismert Ascomycota mitokondriális HMG-box fehérjékkel ( $P$. anserina MtHmg1, $S$. cerevisiae Abf2, C. albicans Gcf1 és $P$. polycephalum Glom), a nyálkagomba $P$. polycephalum Glom, valamint a metazoák Tfam fehérjéivel (C. elegans HMG-5, Paracentrotus, Xenopus, madár, egér és emlős Tfam) (6. ábra). A vizsgálatba bevontuk a HmbA-t és annak S. cerevisiae (NHP6A, NHP6B) és S. pombe (SPAC57A10) homológjait (6. ábra).

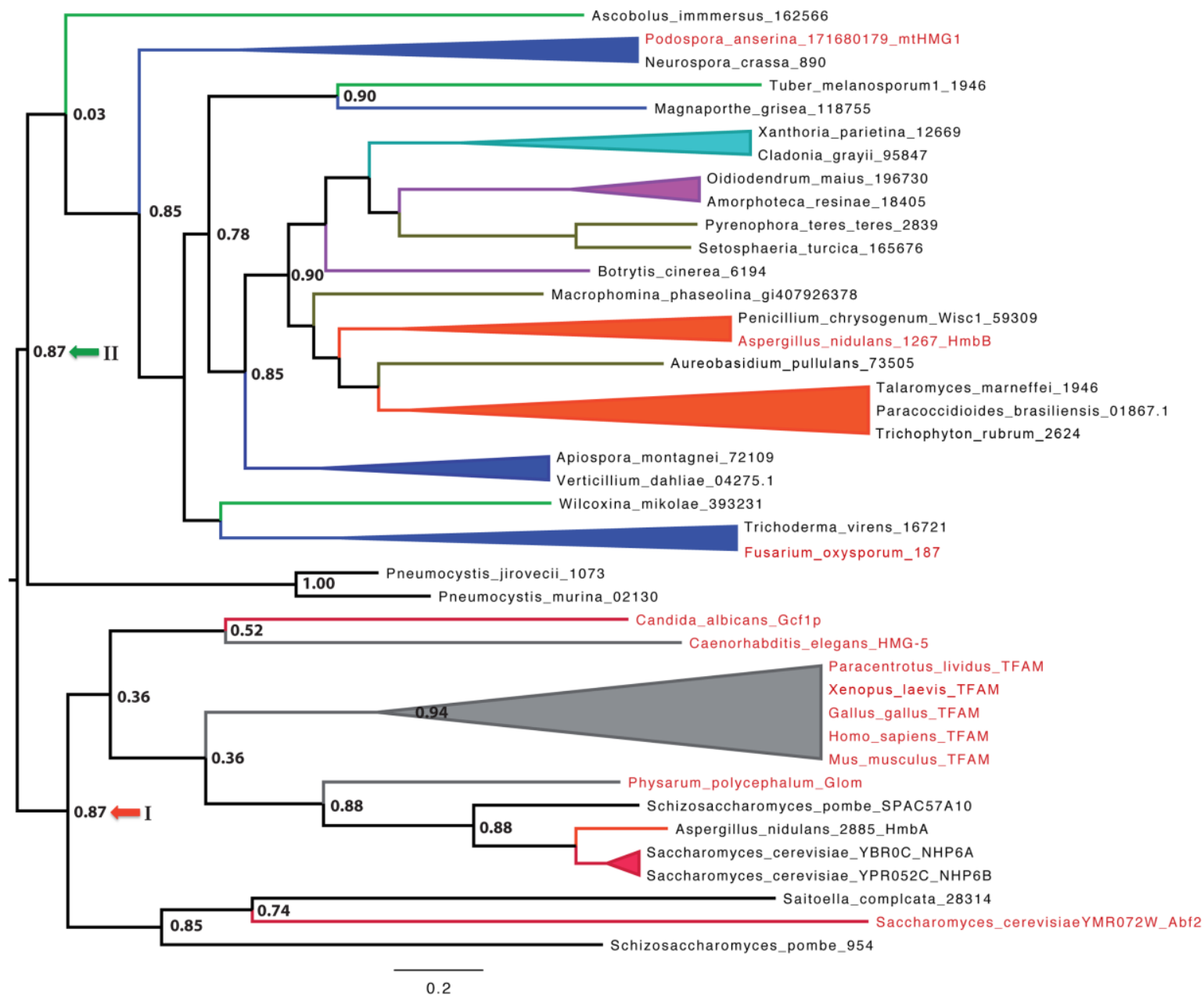

6. ábra: Az A. nidulans, P. anserina, Tuber melanosporum, Pneumocystis jirovecii és $S$. pombe fajok HmbBhomológ fehérjéinek, valamint az A. nidulans és $S$. cerevisiae HmbA-homológ fehérjéinek szekvenciaillesztése. A valószínüsíthető ortológok mellett a fa az összes mitokondriális DNS-en ható HMGfehérjét tartalmazza fajoktól függetlenül, valamint néhány $S$. cerevisiae, S. pombe, Saitoella complicata (a Taphrinomycotina bazális faja) és A. nidulans szekvenciát külső csoportként. A mitokondriális DNS-en ható ismert fehérjék neveit vörös színnel tüntettük fel. A kládok színkódjai az alábbiak: nem gomba szekvenciák: 
szürke, Saccharomycotina: vörös, Taphrinomycotina: fekete. A Pezizomycotina altörzsön belül az alábbi színkódokat használtuk: zöld: Pezizomycetes, narancs: Eurotiomycetes, oliva: Dothideomycetes, világos kék: Lecanoromycetes, lila: Leotiomycetes, kék: Sordariomycetes. Az elágazásoknál található értékek megközelítő "likelihood" arány tesztek, melyeket csak a föbb elágazások esetén tüntettünk fel. Az I. és II. kládot meghatározó elágazásokat vörös és zöld nyilak jelölik.

A HmbB fehérje ortológjai csaknem minden Pezizomycotina csoportba tartozó fajban megtalálhatóak. Az Aulographum hederae (Dothideomycetes), Blumeria graminis (Sordariomycetes) és Dissoconium aciculare (Dothideomycetes) fajokban nincs ortológ fehérje. A kládokba történő rendeződés alapján fény derült arra, hogy a HmbB ortológjai a Pezizomycotina csoporton kívül még a Taphrinomycotina csoportba tartozó Pneumocystis fajokban is megjelennek (II-es klád). Ez rendkívül érdekes, mivel a szintén Taphrinomycotina Schizosaccharomyces-ek Pneumocystis fehérjével adott homológjai inkább a Saccharomycetales csoportban található fehérjékkel állnak ortológ kapcsolatban (Ies klád). A 6. ábrán egyértelmủen megmutatkozó II-es klád monofiletikus eredetü és jól elkülönül a szintén monofiletikus I-es kládtól, ahol az A. nidulans HmbA, élesztő Nhp6A/B és emlős Tfam is feltünik a C. elegans HMG-5, C. albicans Gcf1, $P$. polycephalum Glom és S. cerevisiae Abf2 fehérjék mellett. Feltételezhetően a mitokondriális HMG-box fehérjék a sejtmagi HMG-box proteinekből többször és függetlenül evolválódtak.

\subsection{4. $\mathrm{HmbC}$}

Az AN10103 (HmbC) két HMG-box domént hordoz. In silico vizsgálataink alapján a Hmo1 (S. cerevisiae) és Sp-Hmo1 (S. pombe) a legközelebbi jellemzett homológjai. Ezek a fehérjék (a $S$. cerevisiae Hmo2 fehérjével együtt) az N-terminálison egy kevéssé, a Cterminálison pedig egy erősen konzervált HMG-box domént hordoznak, utóbbit egy erősen poláros szekvencianyúlvány követi (Lu és mtsai. 1996, Albert és mtsai. 2013). Ezt a szerkezeti tagolódást a $\mathrm{HmbC}$ fehérjén is megtaláljuk. S. cerevisiae-ben a kevéssé konzervált $\mathrm{N}$-terminális domén a Hmo1 fehérjében dimerizációs funkciót lát el (Xiao és mtsai. 2010), ugyanakkor a Hmo1-el paralóg Hmo2 fehérje esetében DNS-kötő szerepet játszik (Ray és Grove 2012). A Hmo1 számos szerepet tölthet be, pl. stimulálhatja a Pol-I transzkripciós aktivitását a nukleoluszban (Albert és mtsai. 2013). A Hmo2 pedig a DNS kettős szálú törése esetén kötődik a DNS-hez és az INO80 komplex részeként részt vesz a kettős szálú törés javításában (Ray és Grove 2009). 


\subsection{A HmbA vizsgálata}

\subsubsection{A hmbAA deléciós törzs létrehozása}

A $h m b A$ gén deletálására létrehozott szubsztitúciós kazettát a Double Joint PCR technikával állítottuk elő (4.9. fejezet). Szelekciós markerként a riboB ${ }^{+}$gént használtuk. A konstrukciókészítéshez felhasznált indítószekvenciákat az III. táblázat tartalmazza. A deléció létrehozásához egy pabaAl riboB2 auxotróf $A$. nidulans törzset használtunk (HZS.120). A riboflavinra nézve prototróf transzformánsok közül 30 törzset izoláltunk további vizsgálatokra. A $h m b A$ szekvencia detektálására tervezett PCR-alapú előszelekciót (hmbA frw és hmbA rev indítószekvenciák) követően, Southern-hibridizáció segítségével választottunk ki egy olyan törzset (HZS.205), mely esetében a deléciós kazetta egy kópiában integrálódott a genomba, a $h m b A$ lókuszban. A Southern-hibridizációs stratégiát a 13. ábra mutatja be.

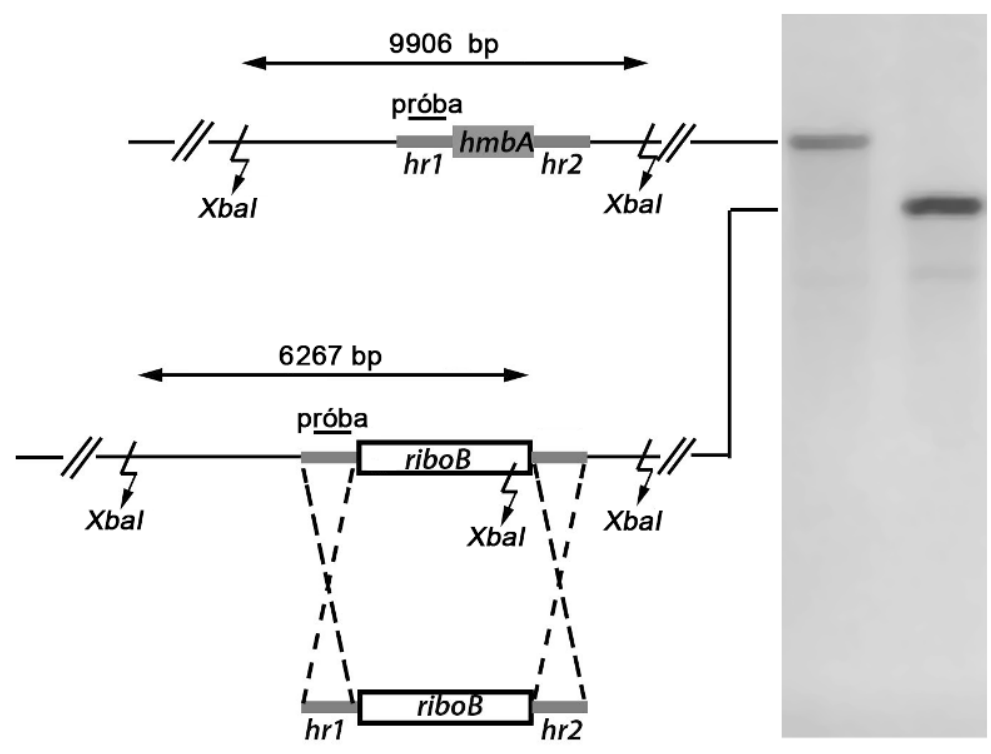

7. ábra: A $h m b A \triangle$ törzsek Southern-blot vizsgálata. A Double Joint PCR eljárással létrehozott, ribo $B^{+}$ szekvenciát tartalmazó szubsztitúciós kazetta sémája az ábra alján látható. A rövid szürke szegmensek a targetálást szolgáló, a genomi régióval homológ szakaszokat jelölik (hr1: a deletálás helyétől upstream irányba eső szekvencia, hr2: a deletálás helyétől downstream irányba eső szekvencia). A $h m b A^{+}$és a potenciális deléciós mutánsok DNS-ét $X b a$ I enzimmel emésztettük. A cikk-cakkos vonalak az XbaI hasítóhelyeket jelölik. Hibridizációs próbának PCR-eljárással (hmbA upst frw és hmbA upst rev indítószekvenciák, lásd III. táblázat) felszaporított szekvenciát használtunk, melyet az ábrán ,,próba” névvel jelöltünk. A kettős nyilak az XbaIemésztésből származó termékek méretét jelölik. A jobb oldalon egy Southern-hibridizációs membránt ábrázoltunk a $h m b A^{+}$(HZS.120, bal oldal) és $h m b A \Delta$ (HZS.205, jobb oldal) törzsek hibridizációs jeleivel. A felső séma az intakt $h m b A$ lókuszt, az alsó a kazetta beépülése esetén létrejövő ribo $B^{+}$szelekciós markerrel szubsztituált lókuszt ábrázolja. A szaggatott vonalak homológ rekombinációs eseményeket jelölnek. 


\subsubsection{A hmbA $\triangle$ törzs jellemzése}

Vizsgáltuk az hmbAム törzs szexuális és aszexuális spóraképzését, azok csírázóképességét és nem tapasztaltunk eltérést a $h m b A^{+}$kontroll törzshöz viszonyítva. A szénforrás- és nitrogénforrás-hasznosítási képesség, illetve a stresszfaktorokkal szembeni tolerancia (hő, ozmotikus és oxidatív stressz) szintén nem változott meg a deléciós törzsben. A megfigyelt fenotípusokat az 5.2.2.1.-5.2.2.4. fejezetekben tárgyaljuk.

\subsubsection{A $h m b A \triangle$ törzs alacsony növekedési rátája}

Elözetes vizsgálataink eredményeként azt tapasztaltuk, hogy a $h m b A \Delta$ törzs a vad típusú kontrollhoz képest (HZS.118) alacsonyabb növekedési rátát mutat (8. ábra). A növekedési rátában megmutatkozó különbség különböző szénforrások és nitrogénforrások használata esetén sem változott. A hmbA4 törzs növekedési rátája 41\%-os növekedést $(\mathrm{p}<0,05)$ mutatott $1 \mathrm{M}$ szorbitol ozmostabilizátor jelenlétében, míg a $h m b A^{+}$törzs esetén az ozmostabilizátor nem befolyásolta a növekedést.

A
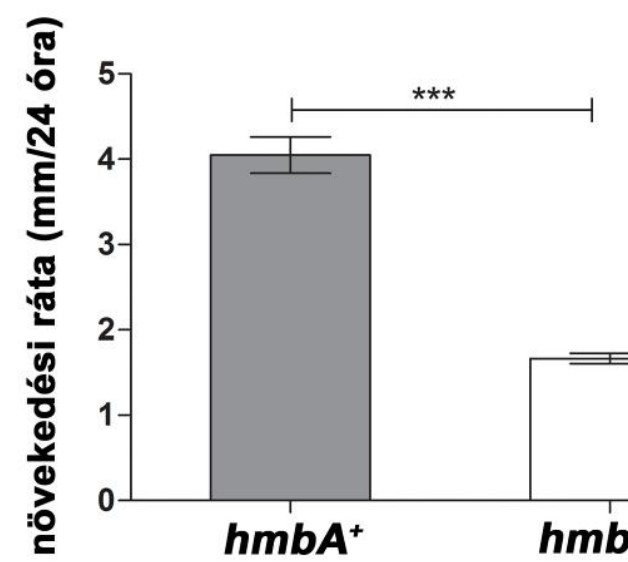

8. ábra: A $h m b A^{+}$(HZS.118) és $h m b A 4$ (HZS.205) törzsek növekedésének összehasonlítása. A: $37^{\circ} \mathrm{C}$-on, MM-táptalajon nevelt $h m b A^{+}$és $h m b A \triangle$ kolóniák növekedési rátájának összehasonlítása a 48 és 96 órás inkubációk közti telepátmérő növekedésekből számítva. Az átlagokat és a szórásokat 3 mérésből számítottuk. A szignifikanciákat csillagokkal jelöltük (*** p<0,0005). B: MM-táptalajon $\left(37^{\circ} \mathrm{C}, 48\right.$ óra) nevelt $h m b A^{+}$és hmbA $\triangle$ kolóniák.

\subsubsection{A HmbA hiányában megváltozik az alacsony pH-értékhez történő adaptáció}

Különböző kémhatású táptalajon történő növekedés vizsgálata során megállapítottuk, hogy a hmbA4 törzs növekedési rátája csak az erősen savas ( $\mathrm{pH}$ 2,2) kémhatáson tér el a $h m b A^{+}$törzstől. Megfigyeltük továbbá, hogy a $h m b A^{+}$törzs kolóniái erősen pigmentáltak voltak a 2,2 pH-n, ami a hmbA 4 törzs esetén nem volt megfigyelhetö. A $h m b A \Delta$ törzs alacsony pH-val szembeni eltérő toleranciája $0,7 \mathrm{M} \mathrm{KCl}$ táptalajhoz történő adásával 
részben komplementálható volt (9. ábra). Ez a fenotípus párhuzamba állítható az nh6pA/B dupla deléciós $S$. cerevisiae esetében megfigyelt ozmotikus stabilizátor hozzáadásával kúrálható növekedési rendellenesség fenotípussal (Costigan és mtsai. 1994).

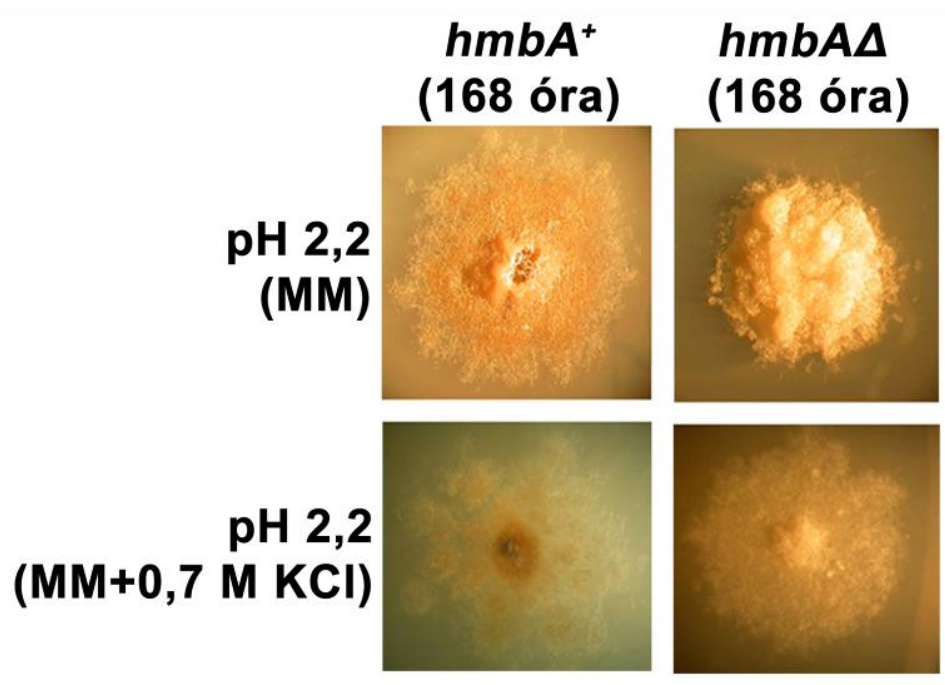

9. ábra: A $h m b A^{+}$(HZS.118) és $h m b A \Delta$ (HZS.205) kolóniák morfológiája pH 2,2 értékre beállított, ozmotikusan nem stabilizált (MM) és ozmotikusan stabilizált $(\mathrm{MM}+0,7 \mathrm{M} \mathrm{KCl})$ táptalajokon. A táptalajok felületére oltott tenyészeteket $37^{\circ} \mathrm{C}$-on inkubáltuk 168 órán keresztül.

5.2.2.3. A HmbA szerepe a másodlagos metabolitok szintézisében

Mivel a HMG-box fehérjék általános kromatinkötő fehérjék, ezért hatással lehetnek a heterokromatikus régiók aktivizálására, ezzel befolyásolva a tipikusan fakultatív heterokromatinba szerveződő másodlagos metabolit génklaszterek, így a sterigmatocisztin bioszintézis génklaszterek kifejeződését. Ennek kiderítésére megvizsgáltuk a $h m b A \Delta$ törzs sterigmatocisztin-termelését. Vékonyréteg-kromatográfiás (TLC) eljárással megvizsgálva a hmbA $\triangle$ micéliumok másodlagos metabolit-tartalmát, a kontroll (HZS.118) törzshöz képest eltérő másodlagos metabolitprofilt figyeltünk meg. A $h m b A \Delta$ törzs nem termelt TLC-vel kimutatható mennyiségü sterigmatocisztint (10. ábra). 


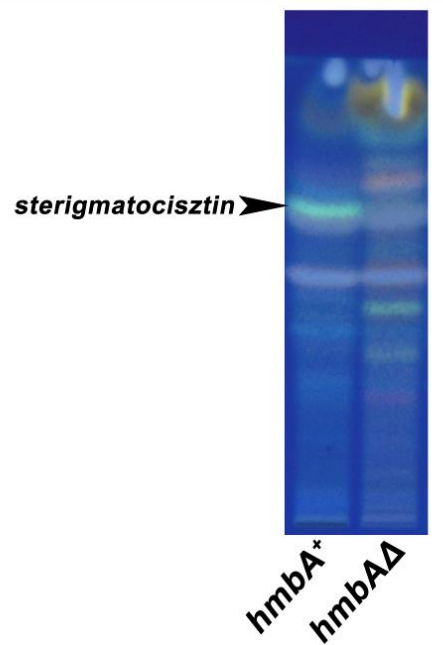

10. ábra: Másodlagos metabolitok vékonyréteg kromatogramja $h m b A^{+}$(HZS.118) és $h m b A \triangle$ (HZS.205) törzsek mintái esetén. A kromatogramon világoszöld színű sávként megjelenő sterigmatocisztin másodlagos metabolitot nyílheggyel jelöltük a $h m b A^{+}$mintában.

\subsubsection{A HmbA szerepe a trehalóz bioszintézisében}

A trehalóz általános védő szerepet tölt be az A. nidulans-ban különféle stresszfaktorokkal szemben (Fillinger és mtsai. 2001), így a hmbA $\Delta$ törzs alacsony $\mathrm{pH}$ értékhez történő sérült adaptációjában is szerepet játszhat. Ennek igazolására vékonyrétegkromatográfiás eljárással hasonlítottuk össze a $h m b A \Delta$ és $h m b A^{+}$törzsek trehalóztermelő képességét. A vizsgálatot nyugvó állapotú konídiumokon ( 0 óra) és micéliumokon (24 óra) is elvégeztük (11. ábra). A vizsgálat eredményeként azt találtuk, hogy a deléciós törzs a kontroll (HZS.118) törzshöz képest csökkent trehalóztartalommal rendelkezik.

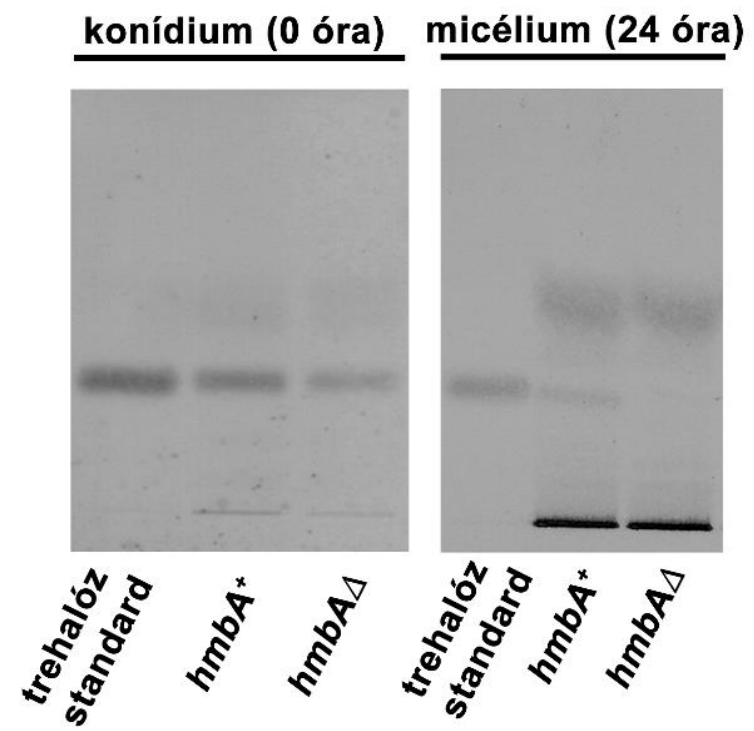

11. ábra: Nyugvó konídiumok ( 0 óra) és micéliumok (24 óra) trehalóztartalmának vizsgálata vékonyrétegkromatográfiával $h_{m b A^{+}}$(HZS.118) és hmbA 4 (HZS.205) törzsek mintáiból. A trehalózt standard segítségével azonosítottuk.

A HmbA funkcionális elemzése az itt bemutatott vizsgálatokkal elkezdődött, de további részletes vizsgálatok szükségesek a fenotípusok vizsgálatára. 


\subsection{A HmbB vizsgálata}

\subsubsection{A hmbB gén kifejezödése csírázó konidiumokban és gombafonalakban}

Megvizsgáltuk a $h m b B$ mRNS kifejeződését a csírázás 30. percében, valamint 3, 8, 22, 36 és 48 óra tenyésztést követően (6. ábra).

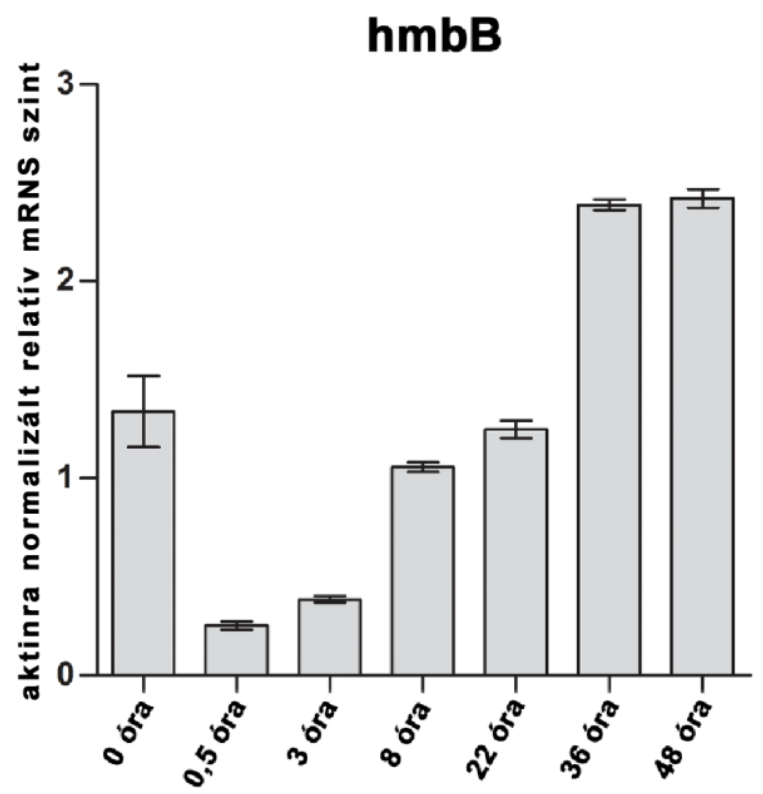

12. ábra: A $h m b B$ mRNS mennyisége a gomba fejlődése során. Az mRNS-szinteket $h m b B^{+}$törzsben (HZS.120) mértük nyugvó konídiumokban ( 0 óra), csírázó konídiumokban ( 0,5 és 3 óra) és micéliumokban ( 8 , 22, 36 és 48 óra). Az mRNS-szinteket aktinra normalizáltuk.

Látható, hogy a HmbB-t kódoló mRNS mennyisége jelentős már az intaktív spórákban is. Az mRNS mennyisége a csírázás első 30 percében lecsökken, majd a csírázás izotropikus fázisának végére (3 óra) ismét megnő, amely növekedés tovább folytatódik a micéliális növekedés során $(8,22,36$ és 48 óra).

5.3.3. A hmbBد deléciós törzs és a fúziós konstrukciókat (hmbB-gfp, gfp-hmbB és hmbB-histag) kifejezö törzsek létrehozása

\subsubsection{A hmbB $\Delta$ deléciós törzs létrehozása}

A $h m b B$ gén deletálására létrehozott szubsztitúciós kazettát a Double Joint PCR módszerrel állítottuk elő (4.9. fejezet). Szelekciós markerként a riboB ${ }^{+}$gént (GTPcikohidroláz, a riboflavin szintéziséhez szükséges egyik gén) használtuk. A konstrukciókészítéshez felhasznált indítószekvenciákat az III. táblázat tartalmazza. A deléció létrehozásához egy pabaA1; riboB2 mutációkat tartalmazó, auxotróf A. nidulans törzset használtunk (HZS.120). A riboflavinra nézve prototróf transzformánsok közül 30 
törzset izoláltunk további vizsgálatokra. A $h m b B$ szekvencia detektálására tervezett PCRalapú előszelekciót követően (hmbB frw és hmbB rev indítószekvenciák), Southernhibridizáció segítségével választottunk ki két olyan törzset (HZS.212, HZS.213), melyek esetében a deléciós kazetta egy kópiában integrálódott a genomba, a $h m b B$ lókuszban. A Southern-hibridizációs stratégiát a 13. ábrán mutatjuk be.

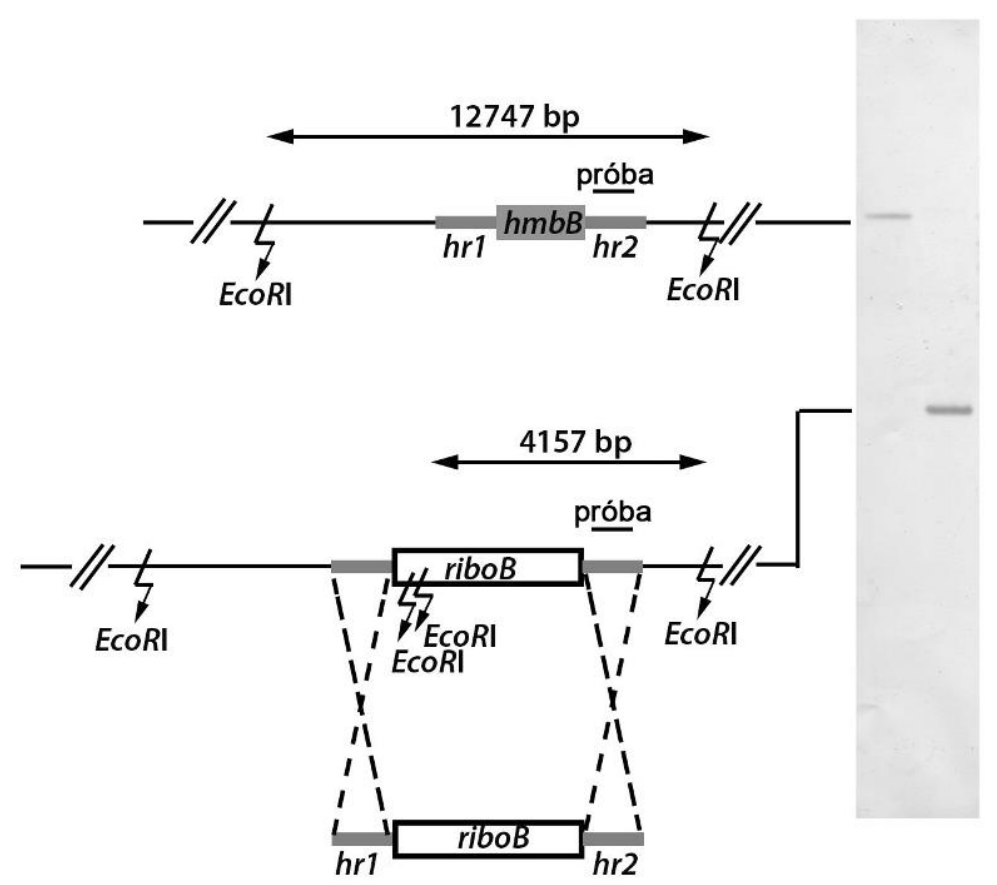

13. ábra: A $h m b B \triangle$ törzsek Southern blot vizsgálata. A double joint PCR eljárással létrehozott, riboB ${ }^{+}$ szekvenciát tartalmazó szubsztitúciós kazetta sémája az ábra alján látható. A rövid szürke szegmensek a targetálást szolgáló, a genomi régióval homológ szakaszokat jelölik (hr1: a deletálás helyétől upstream irányba eső szekvencia, hr2: a deletálás helyétől downstream irányba eső szekvencia). A $h m b B^{+}$és a potenciális deléciós mutánsok DNS-ét EcoRI enzimmel emésztettük. A cikk-cakkos vonalak az EcoRI hasítóhelyeket jelölik. Hibridizációs próbának PCR-eljárással (hmbB down frw és hmbB down rev indítószekvenciák, lásd III. táblázat) felszaporított szekvenciát használtunk, melyet az ábrán ,próba” névvel jelöltünk. A kettős nyilak az EcoRI-emésztésből származó termékek méretét jelölik. A jobb oldalon egy Southern-hibridizációs membránt ábrázoltunk a $h m b B^{+}$(HZS.120, bal oldal) és $h m b B \Delta$ (HZS.212, jobb oldal) által adott hibridizációs jelekkel. A

felső séma az intakt $h m b B$ lókuszt, az alsó pedig a kazetta beépülése esetén létrejövő ribo $B^{+}$szelekciós markerrel szubsztituált lókuszt ábrázolja. A szaggatott vonalak homológ rekombinációs eseményeket jelölnek.

\subsubsection{A $h m b B$-gfp fúziós konstrukciót kifejező törzs létrehozása}

A 4.10.1. fejezetben leírtak szerint létrehozott kazettát (,pantoB ${ }^{+} h m b B$-gfp fúziós kazetta") a pantoB100 (pantoténsav auxotróf) hmbB $\triangle$ törzsbe (HZS.318) transzformáltuk. 47 transzformáns törzset vizsgáltunk meg, melyek közül 22 mutatott GFP-fluoreszcenciát. A törzsek Southern-hibridizációval történő vizsgálata szerint 5 törzsben integrálódott a kazetta a $h m b B$ régióba. A várakozásokkal ellentétben azonban mind az 5 törzs prototróf volt riboflavinra nézve. Várakozásaink szerint a fúziós kazetta $h m b B$ lókuszba történő integrációja a riboB ${ }^{+}$markergén delécióját kellett volna eredményeznie. Ennek elmaradása 
magyarázható a kazetta cirkularizálódásával, majd egyszeres rekombinációval történő integrálódásával a $h m b B$ lókuszt határoló szekvenciákba. Ezt az eshetőséget Southernhibridizációval kivizsgáltuk és a $h m b B$ és riboB kódoló szekvenciákat használva jelölt próbaként a két szekvencia egy DNS-fragmenten történő lokalizációját állapítottuk meg, amely igazolja az integrációs eseményre vonatkozó elképzelésünket. A transzformáns törzsek közül kettőt (HZS.348 és HZS.349) használtunk fel a mikroszkópos vizsgálatokhoz, valamint a fenotípusos jellemzéshez.

\subsubsection{A $g f p-h m b B$ fúziós konstrukciót kifejező törzs létrehozása}

A 4.10.2. fejezetben leírtak szerint létrehozott kazettát (,panto $B^{+} g f p-h m b B$ fúziós kazetta") a pantoB100 (pantoténsav auxotróf) hmbBA törzsbe (HZS.318) transzformáltuk. Az 54 megvizsgált transzformáns közül 41 esetében figyeltünk meg GFP-fluoreszcenciát. Southern-hibridizációval kimutattuk, hogy 8 transzformáns esetében a kazetta a $h m b B$ lókuszba integrálódott. A C-terminális GFP-fúziós fehérjét kifejező törzsekhez hasonlóan, az összes transzformáns prototróf volt riboflavinra nézve. Southern-hibridizációval itt is alátámasztottuk, hogy ez feltehetőleg a kazetta cirkularizálódása és az azt követő, egyszeres rekombinációval történő integrálódása miatt következett be ugyanúgy, ahogyan az a hmbB$g f p$ fúziós konstrukció esetén is történt.

\subsubsection{A HmbB-His-Tag fúziós fehérjét kifejező törzs létrehozása}

A 4.10.3. fejezetben leírtak szerint létrehozott vektort (pAN-HZS-4) a pantoB100 (pantoténsav auxotróf) hmbBA törzsbe (HZS.318) transzformáltuk. Az öt megvizsgált transzformánsból egy törzs esetében (HZS.352) tapasztaltuk a deléciós mutánsra jellemző fenotípus komplementációját. Southern-hibridizáció segítségével megállapítottuk, hogy az expressziós vektor egy kópiában integrálódott ezen transzformáns törzs genomjába (14. ábra). 


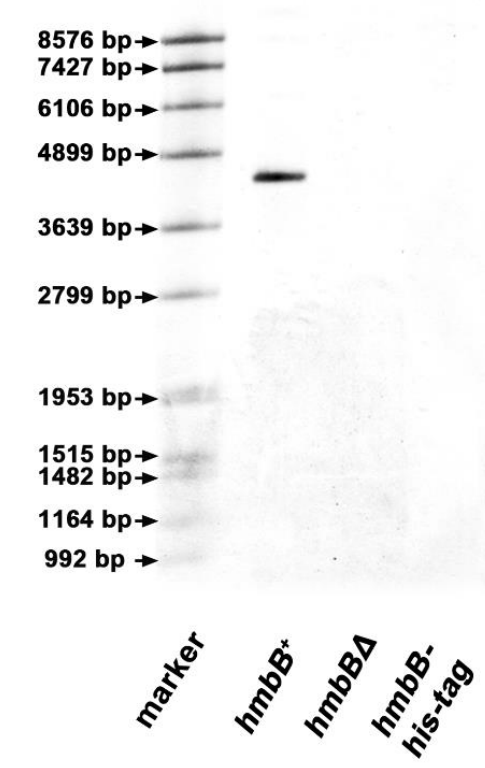

14. ábra: A genomba beépült hmbB-his-tag konstrukciók kópiaszámának meghatározása Southernhibridizációval. A $h m b B^{+}$(HZS.120), hmbBA (HZS.212) és hmbB-his-tag (HZS.352) törzsek DNS-ét BamHI enzimmel emésztettük és molekulasúly-marker (Molecular Weight Marker VII, DIG-labeled, Roche) mellett megfuttattuk. Jelölt próbaként a PCR-eljárással felszaporított $h m b B$ szekvenciát (hmbB frw és hmbB rev indítószekvenciák, III. táblázat) használtuk.

\subsubsection{A hmbBA törzsek jellemzése}

5.3.4.1. Sejtmorfológia-rendellenességek az elsődleges hifákban

A $h m b B$ deléciója a fiatal hifák eltorzult morfológiáját eredményezte. A deléciós törzs elsődleges gombafonalain kerek kitüremkedések képződtek (15. ábra). A jelenségre egy lehetséges magyarázat a sejtfalkomponensek sérült szintézise (Guerriero és mtsai. 2013), vagy a sejtfalintegritást szabályozó szignalizációs útvonalak sérülése (Bussink és Osmani 1999). 
$h m b B^{+}$

(18 óra)

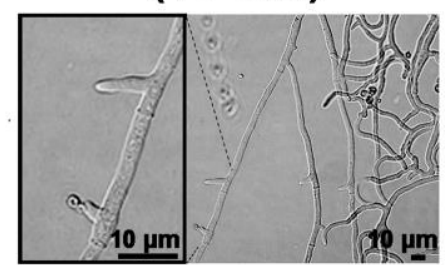

$h m b B \Delta$

(18 óra)

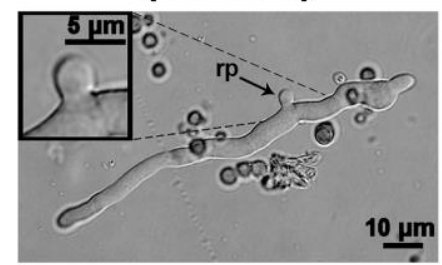

15. ábra: Mikroszkópos felvételek $h_{m b B^{+}}$(HZS.118) és $h m b B \Delta$ (HZS.212) micéliumokról (18 óra inkubálás $37^{\circ} \mathrm{C}$-on). Az „rp” rövidítés kerek kitüremkedést jelöl. A szaggatott vonalak a beágyazott képeken kinagyított részleteket jelölik ki.

5.3.4.2. Növekedési tesztek - oxidatív stresszorokkal szemben mutatott eltérő érzékenység

A gombakolóniák növekedésének vizsgálatához 24 órán keresztül MM-tápoldatban előnevelt kolóniákat használtunk, hogy kiküszöböljük a hmbBA törzsek (HZS.212 és HZS.213) konídiumaik esetében tapasztalható csökkent csírázóképesség hatását. Megvizsgáltuk a deléciós törzs növekedését különböző szén- és nitrogénforrások jelenlétében. Ennek során a deléciós törzsek kismértékben csökkent növekedését figyeltük meg bizonyos szén-, illetve nitrogénforrás használatakor a $h m b B^{+}$törzshöz (HZS.118) képest (16. ábra).

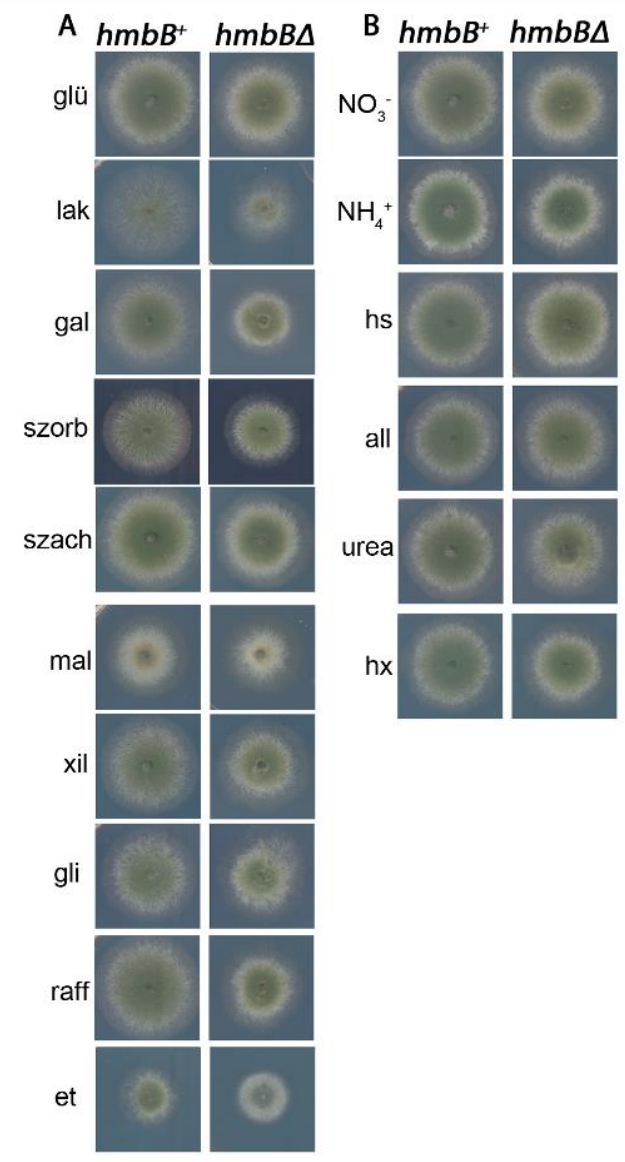

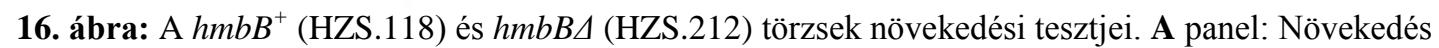
különböző szénforrásokon. Glükóz (glü), laktóz (lak), galaktóz (gal), szorbitol (szorb), szacharóz (szach), maltóz (mal), xilóz (xil), glicerin (gli), raffinóz (raff) és etanol (et) mint kizárólagos szénforrások. Kizárólagos nitrogénforrásként nátrium-nitrátot használtunk. B panel: Növekedés különböző nitrogénforrásokon. Nátrium- 
nitrát $\left(\mathrm{NO}_{3}{ }^{-}\right)$, ammónium $\left(\mathrm{NH}_{4}\right)$, húgysav (hs), allantoin (all), urea (urea) és hipoxantin (hx). Kizárólagos szénforrásként glükózt használtunk. A növekedést 48 óra inkubálást követően rögzítettük.

A hmbBA törzs galaktóz szénforrás használatakor 27\%-al ( $\mathrm{p}<0,005)$, laktóz szénforrás esetén 21\%-al $(\mathrm{p}<0,005)$, raffinóz szénforrás esetén 17\%-al $(\mathrm{p}<0,005)$ növekedett lassabban a $h m b B^{+}$törzshöz képest. A vizsgált nitrogénforrások közül az ammónium esetén mértünk alacsonyabb növekedési rátát a $h m b B \Delta$ törzsnél $(-13 \%, \mathrm{p}<0,0005)$ a vad típushoz viszonyítva.

Megvizsgáltuk a mutáns törzsek toleranciáját különböző stresszágensekkel ozmotikus stressz $(1 \mathrm{M} \mathrm{NaCl})$, hőstressz $\left(42^{\circ} \mathrm{C}\right)$ és oxidatív stressz $(0,4 \mathrm{mM}$ menadion és 1,8 mM diamid) - szemben (17. ábra). A deléció hatására $42{ }^{\circ} \mathrm{C}$-on kismértékben csökkent növekedési képességet $(-23 \%, \mathrm{p}<0,05), 0,4 \mathrm{mM}$ menadion jelenlétében erősen csökkent növekedést $(-85 \%, \mathrm{p}<0,0005)$ tapasztaltunk. A két független transzformáns (HZS.212 és HZS.213) azonos érzékenységet mutatott a menadionnal szemben, mely tulajdonság a deléciós törzsek riboB2 auxotróf törzzsel történő keresztezésekor együtt szegregált a deléció markereként használt riboflavin prototrófiával. Mindkét deléciós törzs esetében mérsékelt rezisztenciát tapasztaltunk diamiddal szemben (17. ábra).

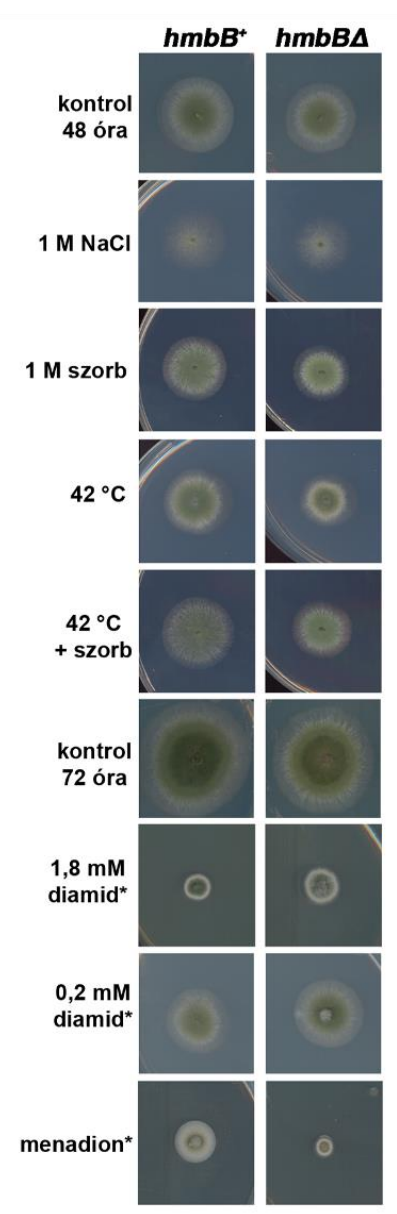

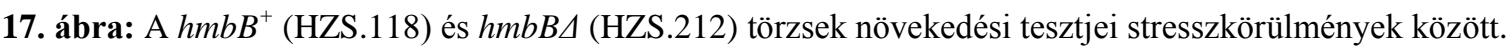
Minden vizsgálat glükóz-nitrát MM-táptalajon történt. Az ozmotikus toleranciát $1 \mathrm{M} \mathrm{NaCl-dal}(1 \mathrm{M} \mathrm{NaCl})$, 
vagy $1 \mathrm{M}$ szorbitollal (1 M szorb) kiegészített táptalajokon vizsgáltuk. A $42{ }^{\circ} \mathrm{C}-$ on mutatott növekedést MMés $1 \mathrm{M}$ szorbitollal kiegészített MM-táptalajokon vizsgáltuk. Az oxidatív stressz ágensek közül menadion $(0,8$ $\mathrm{mM})$ és diamid ( $1,8 \mathrm{mM}$ és $0,2 \mathrm{mM})$ hatását vizsgáltuk. A növekedési teszteket 48 óra inkubációt követően vizsgáltuk, kivéve a csillaggal jelölt esetekben (a csillag 72 óra inkubációt jelöl).

5.3.4.3. A $h m b B \Delta$ törzs oxidatív stresszel szemben mutatott toleranciájának részletes vizsgálata

A $h m b B \Delta$ törzsek esetében a vad típusétól eltérő toleranciát tapasztaltunk diamiddal és menadionnal szemben (Karácsony és mtsai. 2015). Elvégeztük a $h m b B^{+}, h m b B \Delta$ és HZS.352 törzsek növekedési tesztjeit diamid (0,05-3 mM, 12. ábra) és menadion $(0,025-0,4$ mM, 19. ábra) különböző koncentrációit tartalmazó MM-táptalajokon.

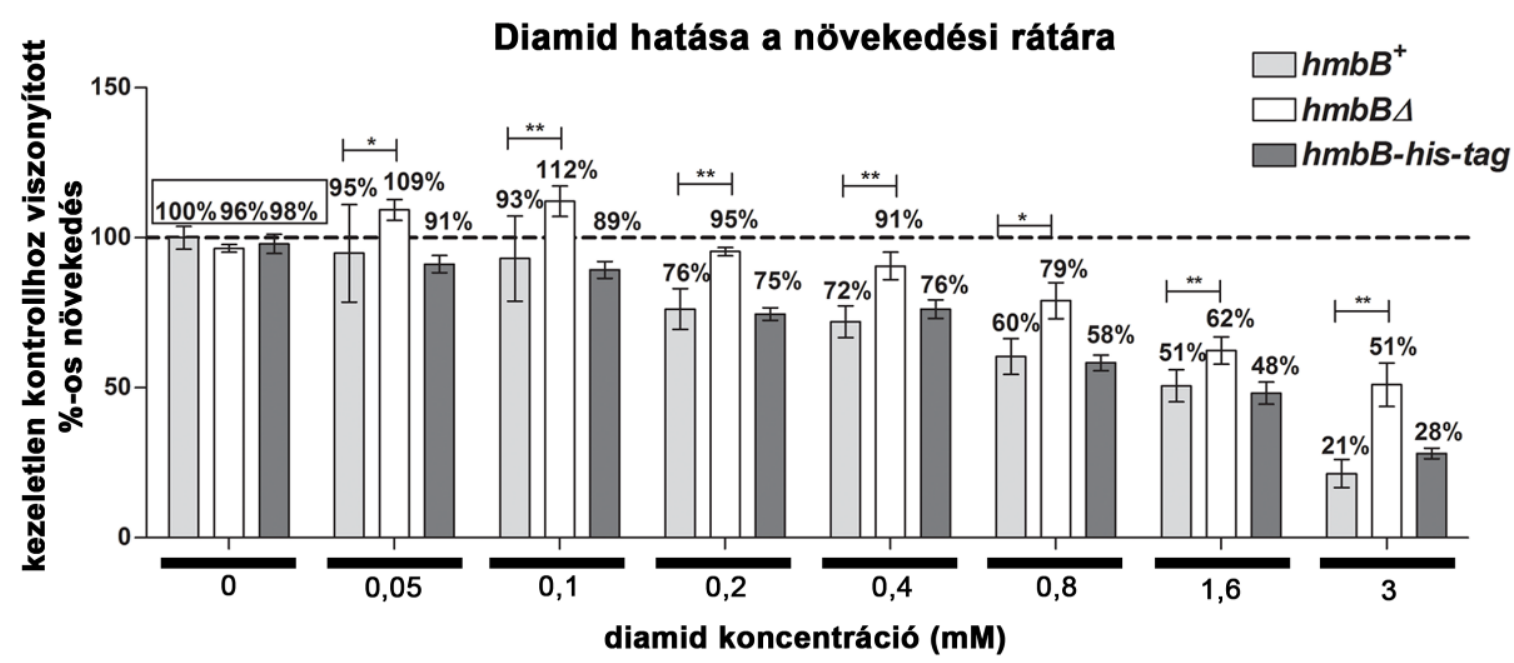

18. ábra: $\mathrm{A} h m b B^{+}$(HZS.118), hmbBA (HZS.212) és a komplementációs kontrollként használt hmbB-his-tag (HZS.352) törzsek növekedési rátája különböző diamid-koncentrációk mellett. A feltüntetett adatok a kezeletlen kontrollhoz viszonyított százalékos értékek. A szignifikanciákat csillagokkal jelöltük $(* \mathrm{p}<0,05$; ** $\mathrm{p}<0,005)$.

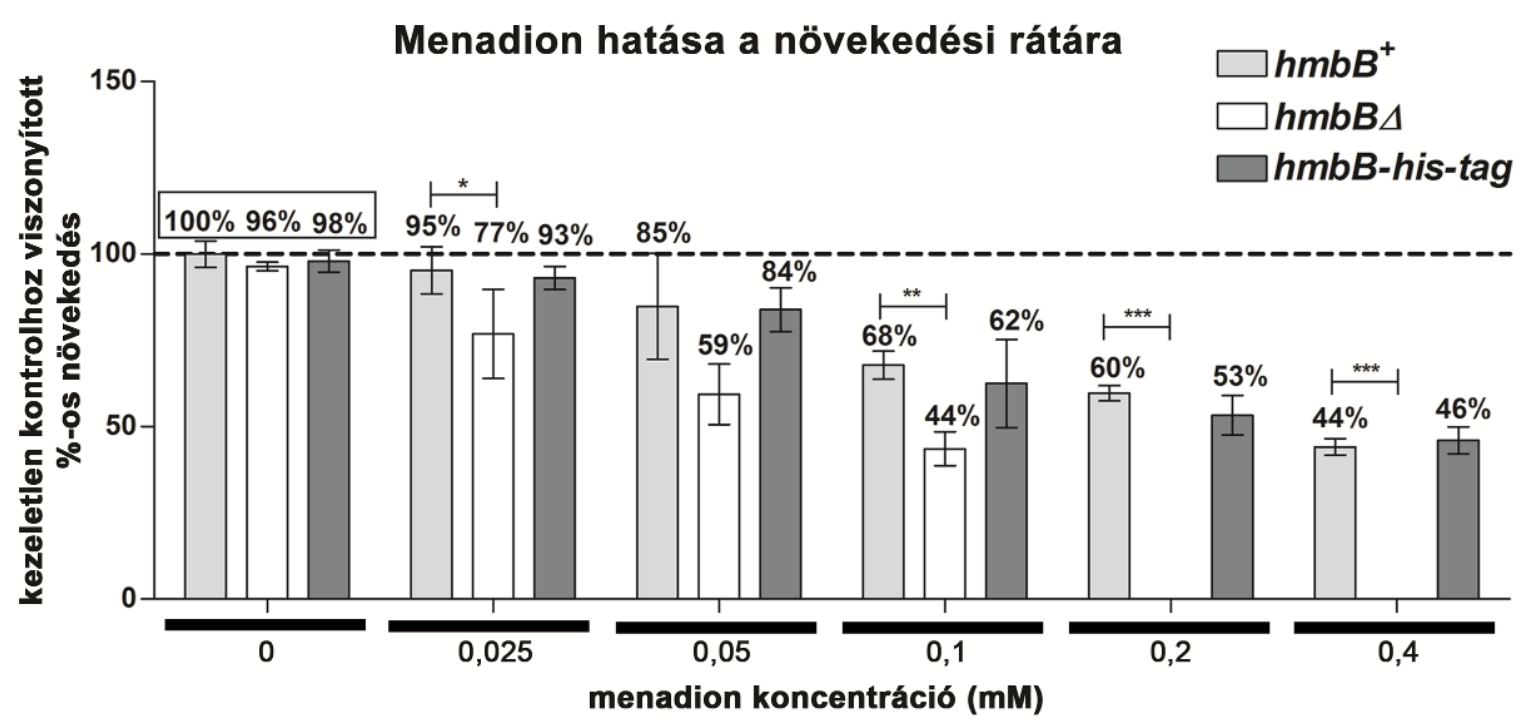

19. ábra: $\mathrm{A} h m b B^{+}$(HZS.118), hmbBA (HZS.212) és a komplementációs kontrollként használt hmbB-his-tag (HZS.352) törzsek növekedési rátája különböző menadion-koncentrációk mellett. A feltüntetett adatok a 
kezeletlen kontrollhoz viszonyított százalékos értékek. A szignifikanciákat csillagokkal jelöltük $(* \mathrm{p}<0,05$; ** $\mathrm{p}<0,005 ; * * * \mathrm{p}<0,0005)$.

Úgy találtuk, hogy az 50\%-os gátást okozó legkisebb menadion-koncentráció ( $\left.\mathrm{MIC}_{50}\right)$ 0,2 és 0,4 mM közé esett a $h m b B^{+}$és HZS.352 törzsek esetében, míg a $h m b B \Delta$ törzs esetében ez az érték 0,05 és $0,1 \mathrm{mM}$ között volt (19. ábra). Csak a deléciós törzs volt képtelen növekedni 0,1 mM-nál magasabb menadion-koncentráció esetén. A diamid esetében a $\mathrm{MIC}_{50}$ érték 1,6 $\mathrm{mM}$ koncentrációnál adódott a $h m b B^{+}$és HZS.352 törzsek esetében, a $h m b B \Delta$ törzs esetében pedig 3 mM-nál (18. ábra). A deléciós törzs minden vizsgált koncentráción magasabb toleranciát mutatott a diamiddal szemben, $0,05 \mathrm{mM}$ és 0,1 $\mathrm{mM}$ koncentrációkban pedig a diamid még fokozta is a törzs növekedési képességét ( $+9 \%$ és $+12 \%, \mathrm{p}<0,05$ és $\mathrm{p}<0,005$ ) (18. ábra). Ez utóbbi eredmény arra utal, hogy a HmbB fehérje hiányában a gombasejtek redox állapota olyan módon tér el a normálistól, melyet a diamid a GSH oxidációjával képes részlegesen helyreállítani.

5.3.4.4. Aszkospóra- és konídiospóra-termelésben, a spórák csírázóképességében tapasztalt rendellenességek, és azok lehetséges okainak vizsgálata

A $h m b B \Delta$ törzs esetében az ivartalan spóraképzö képesség csökkenését mutattuk ki. Mindkét független deléciós transzformáns (HZS.212 és HZS. 213) 30\%-al kevesebb konídiumot hozott létre a $h m b B^{+}$törzshöz képest (20.A ábra). A $h m b B \Delta$ törzs esetében a konídiumok csírázóképessége drasztikusan lecsökkent. A $h m b B^{+}$törzs esetében mért 60\%-os értékhez képest a deléciós törzsnél kevesebb, mint 1\%-os csírázóképességet tapasztaltunk (20.B ábra). A két független deléciós transzformánsnál (HZS.212 és HZS.213) az ivartalan spórák csírázóképességének azonos csökkenését tapasztaltuk. A két deléciós törzset a HZS.140 törzzsel kereszteztük, és 19 illetve 22 ribo $B^{+} h m b B \Delta$ genotípusú utódban a csírázóképesség azonos mértékủ csökkenését figyeltük meg. Ez az eredmény alátámasztotta, hogy az ivartalan spórák csírázóképessége függ a HmbB fehérje jelenlététől (Karácsony és mtsai. 2014). 
A

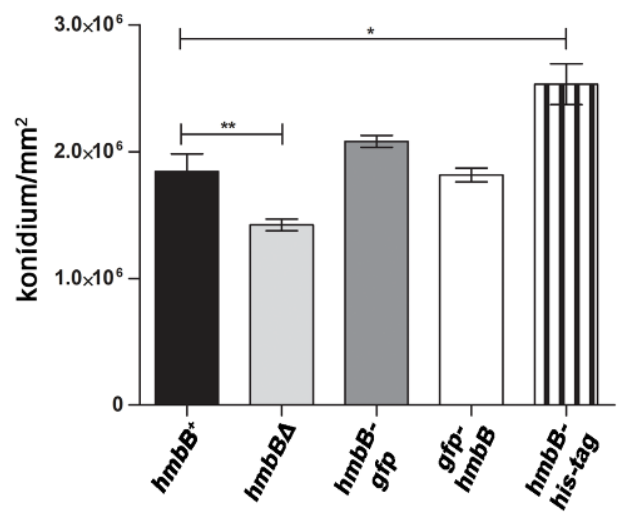

C

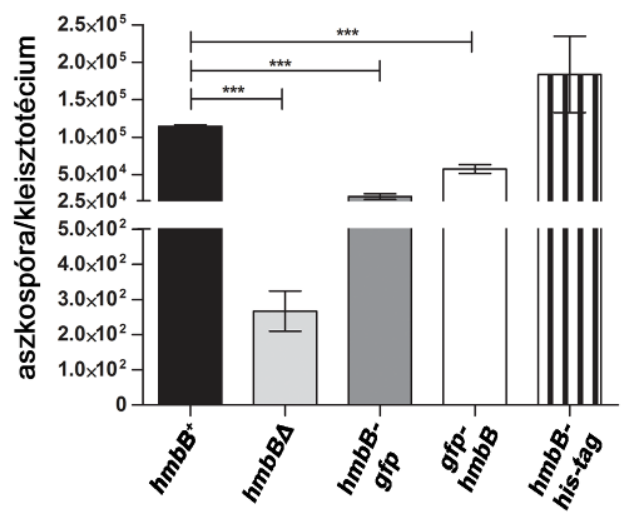

B

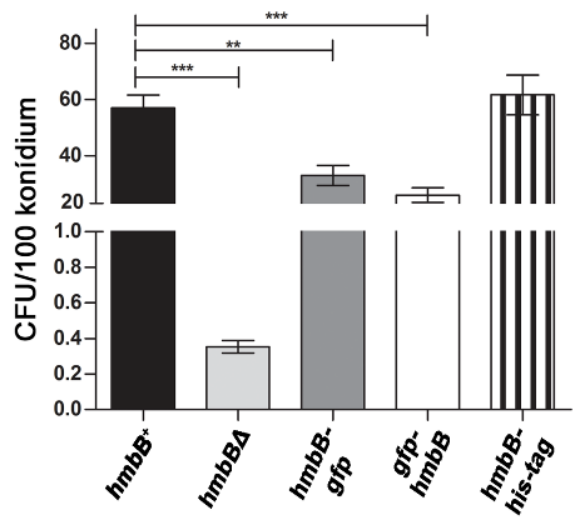

D

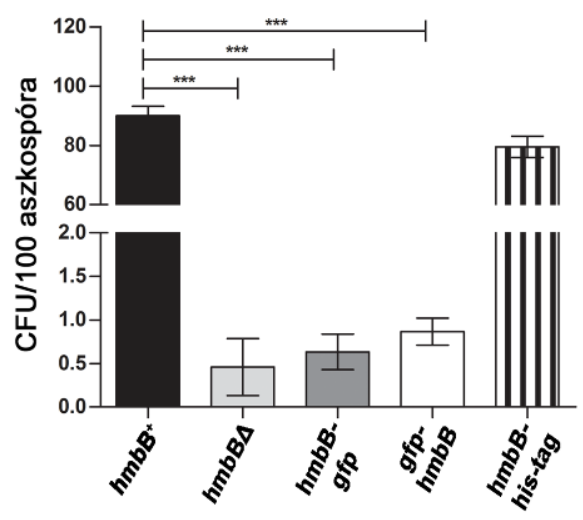

20. ábra: Az ivartalan és ivaros spóraképzési produktivitás és a spórák csírázásóképességének összehasonlító vizsgálata. A: 3 napos kolóniák $1 \mathrm{~mm}^{2}$ felületén képzödött konídiospórák száma. B: A konídiospórák százalékos csírázási képessége (CFU: colony forming unit). C: 1 kleisztotéciumban képződő aszkospórák száma. D: Az aszkospórák csírázóképessége. Az A és $\mathbf{B}$ panelek átlagai és szórásai 3 biológiai párhuzamossal végzett 3 mérés eredményeit mutatják. A $\mathbf{C}$ és $\mathbf{D}$ panelek átlagai és szórásai 5 biológiai párhuzamossal végzett

3 mérés eredményeit mutatják. A szignifikanciákat csillagokkal jelöltük $(* \mathrm{p}<0,05 ; * * \mathrm{p}<0,005 ; * * *$ $\mathrm{p}<0,0005)$. A kísérleteket $h m b B^{+}$(HZS.118), $h m b B \Delta$ (HZS.212), $h m b B$-gfp (HZS.349, C-terminális GFPfúziós fehérjét kifejező törzs), gfp-hmbB (HZS.363, N-terminális GFP-fúziós fehérjét kifejező törzs) és $h m b B$ his-tag (HZS.352, hexahisztidin taggel fúzionált HmbB-t kifejező törzs) törzsekkel végeztük.

A konídiospórák a fialidokról füződnek le. A folyamat során a fialidban található sejtmag osztódásából keletkező egyik leánymag az apikális régióhoz vándorolva kerül a képződő konídiospórába (Sewall és mtsai. 1990, Timberlake 1993). Megvizsgáltuk, hogy a spóraképzés során képződő első két konídiumsor konídiumainak csírázóképessége megasabb-e a később képződött spórákhoz képest. Ez azt jelezné, hogy valamely, a csírázáshoz szükséges faktor a vezikulumból transzportálódik a képződő konídiumokba és a konídiogenezis előrehaladtával kihígul a később képződött konídiumokban. Ilyen faktor lehet például a $\mathrm{Fe}^{2+}$ ion, mely a ferrikrocin sziderofórhoz kötődve transzportálódik a micéliumból a képződő konídiumokba és ott felhalmozódva fontos szerepet tölt be a csírázóképességben (Eisendle és mtsai. 2006). A kísérlet során a fialidokon képződő első két konídiumsor (16 óra tenyészet) csírázóképességét összehasonlítottuk az összes konídium (48 órás tenyészet) csírázóképességével. A vizsgálat eredményeként megállapítottuk, hogy a 
fiatal konídiumok csírázóképessége kis mértékben ( $\mathrm{kb}$. kétszeresére, $\mathrm{p}<0,05)$ növekedett az összes konídium esetében mért értékhez viszonyítva (21. ábra), ami még mindig csak kb. 1\% csírázóképességet jelent.

\section{A vezikulumról lefüződő első két konídiumsor spóráinak csírázóképessége}

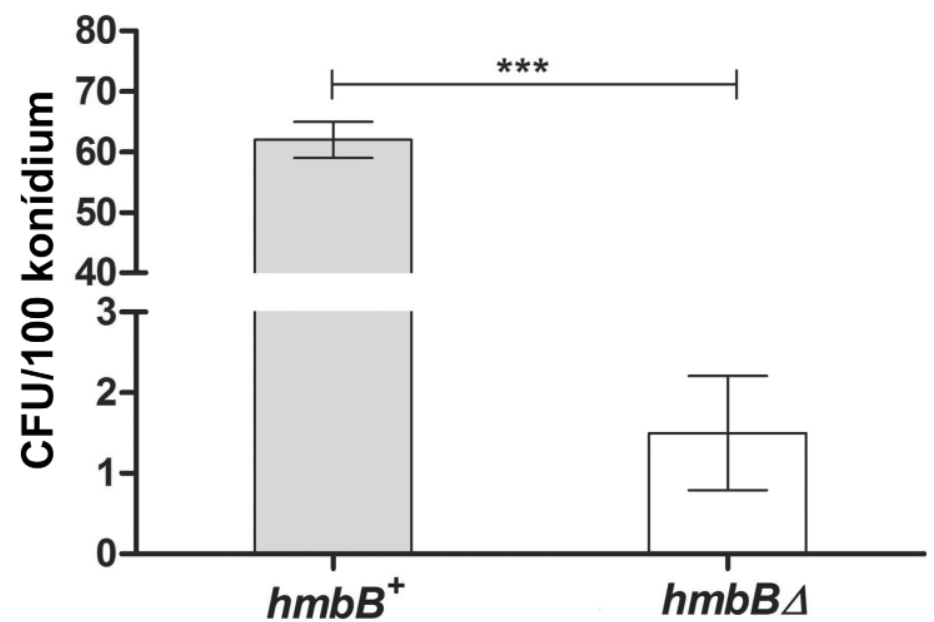

21. ábra: A vezikulumról lefüződő első két konídiumsor spóráinak csírázóképessége $h m b B^{+}$(HZS.118) és hmbB $\triangle$ (HZS.212) törzsek esetében. Az ábrán a konídiumok százalékos csírázóképességét ábrázoltuk (CFU= colony forming unit). A feltüntetett átlagok és szórások 3 biológiai párhuzamossal végzett 3 mérésből adódnak. A szignifikanciákat csillagokkal jelöltük $(* * * \mathrm{p}<0,0005)$.

Megvizsgáltuk az alacsony csírázóképesség öröklődését heterokariotikus micéliumon

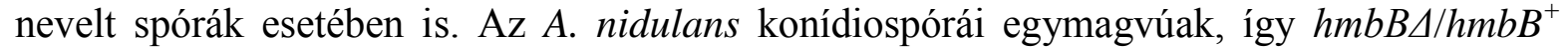
heterokarion felhasználásával vizsgálható, hogy az alacsony csírázóképesség komplementálódik-e a $h m b B^{+}$allélt hordozó spórákban. Ennek érdekében létrehoztunk két független, kiegyensúlyozott heterokariont egy yA2 hmbBA törzs (HZS.385) felhasználásával. Ezt a deléciós törzset kereszteztük egy $y A^{+} h m b B^{+}$törzzsel (LO1516, melyben a $h h o A-m r f p$ fúziós konstrukció a sejtmagok vörös fluoreszcenciáját eredményezi, „het I” törzs) és egy $y A^{+} h m b B$-gfp törzzsel (HZS.359, melyben a hhoA-mrfp és $h m b B$-gfp fúziós konstrukciók vörösen fluoreszkáló sejtmagot és zölden fluoreszkáló mitokondriumokat eredményeznek, „het II” törzs). A törzs csírázóképessége megegyezett a $h m b B^{+}$szülöi törzs (LO1516) csírázóképességével (22. ábra). A törzsek a felsoroltakon felül olyan auxotrófia-markereket is tartalmaztak, amelyek biztosították a keresztezhetőséget (I. táblázat). A heterokarionokról izolált konídiumszuszpenziókban az egyes spórák sejtmagjának típusa (mely a szülöi genotípust hordozza) megállapítható fluoreszcencia alapján, a kicsírázott spórák genotípusa pedig meghatározható a képződött kolóniák színéből és a hordozott auxotrófia-markerek alapján. A mikroszkópos számolások szerint a heterokarionok kiegyensúlyozottak voltak (körülbelül 45\% hmbBA spóra mindkét heterokarion esetében). A heterokarionokról izolált 
hmbB $\triangle$ spórák csírázóképessége 0,26\%-nak (het I) és 0,44\%-nak (het II) adódott, mely nem különbözött szignifikánsan a $h m b B \Delta$ kolóniákon létrejött spórák csírázóképességétöl (22. ábra). Megállapítottuk, hogy a konídium-csírázóképességgel kapcsolatos deléciós fenotípus autonóm, következésképpen nem lehet heterokarionokban komplementálni. Ez azért sem meglepö, mivel a sporuláló heterokarionok vezikulumai is már homokariotikusak, a metulák és fialidok ezért szükségszerủen azok, a fialidok pedig már egymagvúak is (Timberlake 1990). Az eredmények egybehangzóak a mitokondriális DNS konidiogenezis során lejátszódó szegregációjával, azonban nem lehet megállapítani, hogy a folyamat konidiogenezis melyik lépésekor játszódik le.

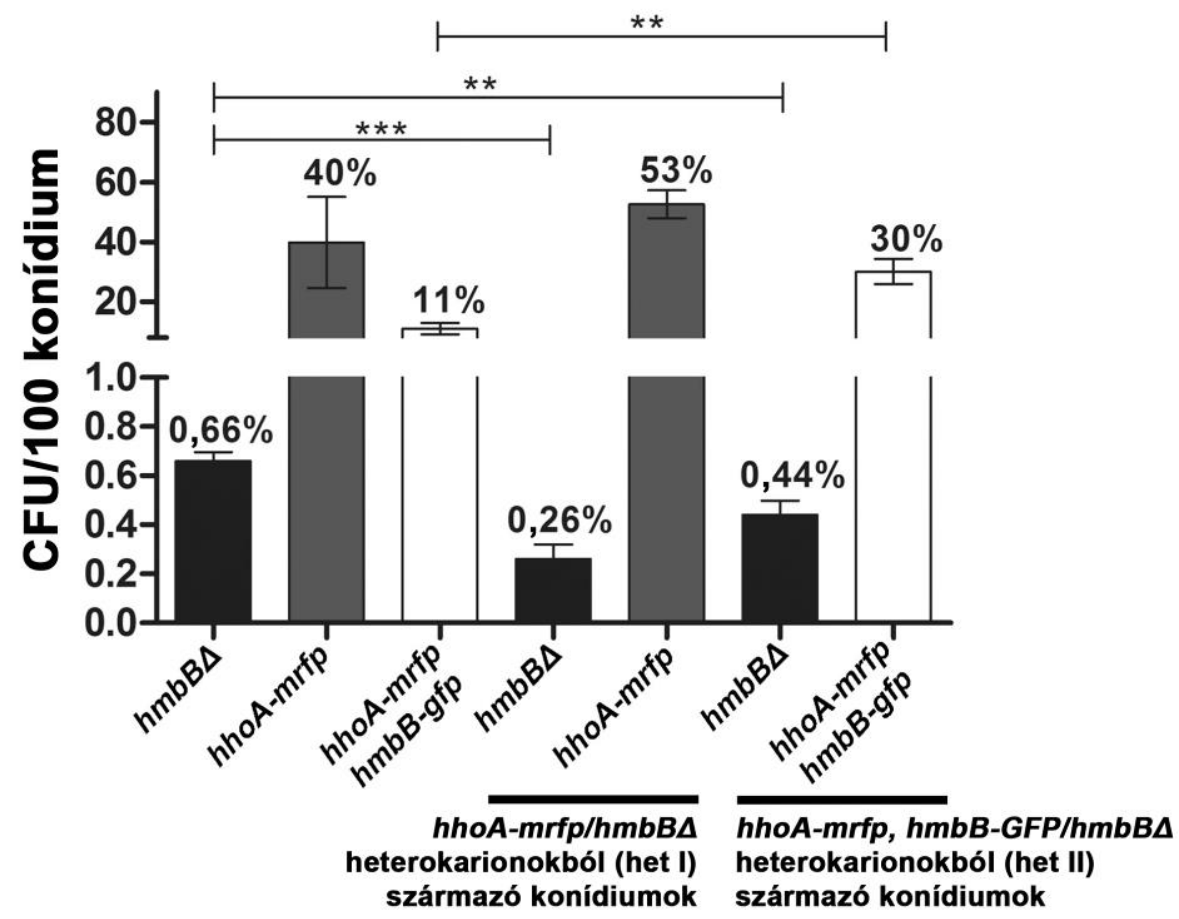

22. ábra: $h m b B^{+} / h m b B \Delta$ genetikai hátterü, heterokariotikus micéliumon képződött konídiumok csírázóképességének vizsgálata. Az ábrán a konídiumok százalékos csírázóképességét ábrázoltuk (CFU= colony forming unit). A vizsgálathoz a hmbBA (HZS.385), hhoA-mrfp (LO1516) és hhoA-mrfp hmbB-gfp

(HZS.359) keresztezési partnereket, illetve a HZS.385/LO156 (hetI) és HZS.385/HZS.359 (hetII) heterokarionok konídiumait használtuk. Az átlagok és a szórások 3 biológiai párhuzamossal végzett 3 mérés eredményeiböl lettek számítva. A szignifikanciákat csillagokkal jelöltük $(* * \mathrm{p}<0,005 ; * * * \mathrm{p}<0,0005)$.

A $h m b B$ gén deletálása nagymértékben redukálta a homozigóta keresztezésekből származó aszkospórák számát és az aszkospórák csírázóképességét (20.C és D ábra). A HZS.212 törzzsel készített mérések eredményei megegyeznek a HZS.213 törzsnél tapasztaltakkal. A hisztidin-taggelt HmbB fehérje (HZS.352) teljes mértékben helyreállította a $h m b B^{+}$fenotípust mind a konídiospórák, mind az aszkospórák képződésének és csírázóképességének tekintetében. A GFP-fúziós konstrukciók esetében helyreállt a konídiospórák képződése és csírázóképessége, valamint az aszkospórák termelődése, 
azonban az aszkospórák csírázóképessége a deléciós mutáns szintjén maradt. A jelenséget a 6.4. részben vitatjuk meg az összes vizsgálati eredmény tükrében.

5.3.4.5. A nem csírázó $h m b B \Delta$ konídiumfrakció metabolikusan aktív konídiospórákat tartalmaz

A ki nem csírázott hmbBム konídiumok mikroszkópos vizsgálata során azt tapasztaltuk, hogy a spórák keresztülmennek az izotropikus növekedésen, viszont mitózisra nem képesek (Karácsony és mtsai. 2014). A $h m b B \Delta$ és $h m b B^{+}$törzsek konídiumait MitoTracker Red FM (mitokondrium-specifikus) festéssel vizsgálva nem tapasztaltunk eltérést a két törzs között (23.B ábra). MTT (3-(4,5-dimetiltiazol-2-il)-2,5-difeniltetrazólium bromid) festést követő mikroszkópos vizsgálattal (Arseculeratne és Atapattu 2004) igazoltuk, hogy a hmbBA törzs nem csírázó konídiumai metabolikus aktivitást mutatnak. A nem csírázó konídiospórák metabolikus aktivitásukat 1 napos inkubációt követően is megőrizték (23.A ábra, 3 és 24 óra)

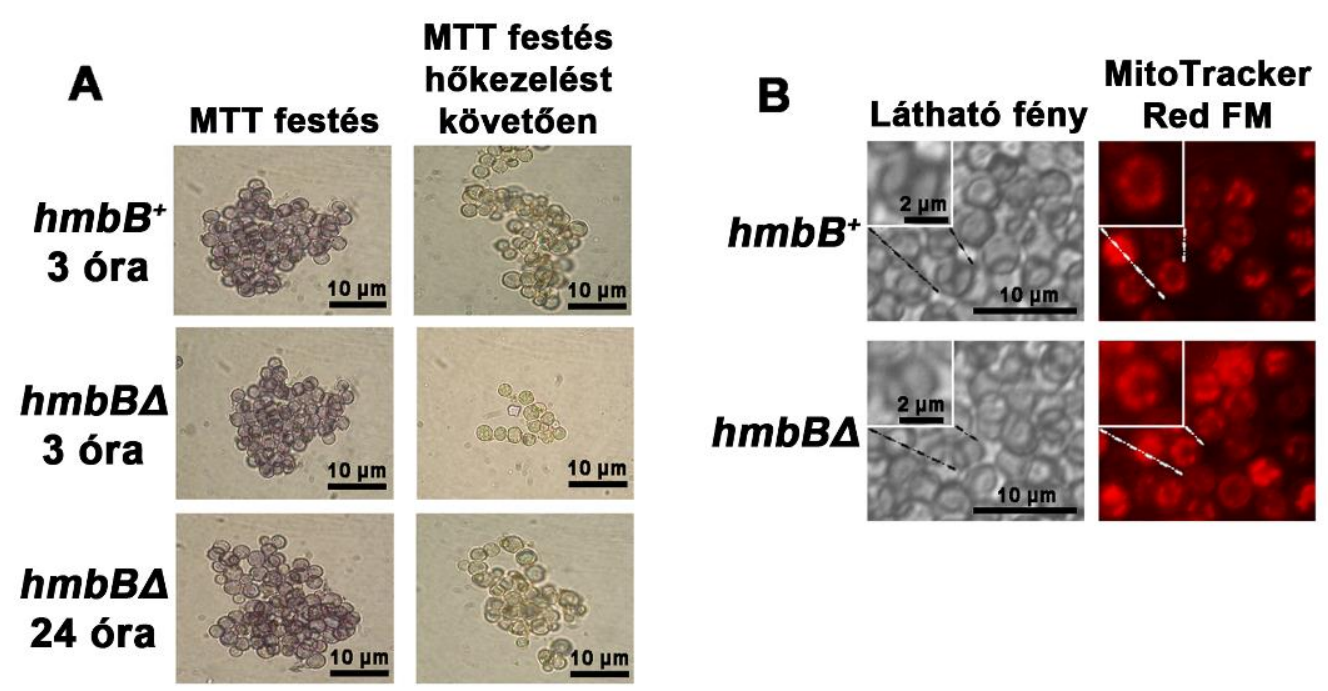

23. ábra: Duzzadó konídiumok MTT és Mitotracker Red FM festése. A: MTT festés. $h m b B^{+}$(HZS.118) és hmbBA (HZS.212) konídiumokat inkubáltunk 3 és 24 órán át MM-tápoldatban. A mintákat kezeletlenül hagytuk (bal oldali oszlop), vagy a festés elött 20 percig forraltuk (jobb oldali oszlop). B: $h m b B^{+}$(HZS.118) és hmbBA (HZS.212) konídiumok MitoTracker Red FM fluoreszcens festékkel festve, 3 órás, MM-tápoldatban történt inkubálást követően.

A hmbBA konídiumok metabolikus aktivitását a 3 órás inkubáció során mért metabolitprofil (5.3.4.6. fejezet) és a spórák respirációs képességének vizsgálata (5.3.4.10.4. fejezet) is alátámasztja. 
5.3.4.6. A hmbB $\Delta$ konídiumok cukor- és polialkohol-spektrumának eltérése a nyugalmi spóra és a duzzadó spóra állapotokban

A nyugalmi és duzzadó ivartalan spórák cukor- és polialkohol-profilját GC-MS analízissel vizsgáltuk meg. A $h m b B \Delta$ törzs (HZS.212) spóráiban ezeknek a vegyületeknek csökkent szintjét mértük a $h m b B^{+}$kontroll törzshöz képest (tízszer kevesebb xilitol, háromszor kevesebb trehalóz, kétszer kevesebb mannóz, galaktóz és mannitol) (V. táblázat). A vizsgált vegyületek megváltozott metabolizmusát figyeltük meg három óra csíráztatást követően a hmbBA törzsben: a D-mannóz, D-glükóz, mannitol és az inozitol nagyobb mértékben metabolizálódott a deléciós törzs esetében (V. táblázat).

V. táblázat: Cukrok és polialkoholok mennyisége nyugvó (0 óra) és duzzadó (3 óra) konídiumokban $h m b B^{+}$ (HZS.118) és hmbBA (HZS.212) törzsek esetén.

\begin{tabular}{|r|c|c|c|c|c|c|c|c|}
\hline Minta & xilitol & D-mannóz & E-galaktóz & D-glükóz & Z-galaktóz & mannitol & inozitol & trehalóz \\
\hline $\boldsymbol{h} \boldsymbol{m} \boldsymbol{b} \boldsymbol{B}^{+}-\mathbf{- 0}$ óra & 40 & 0,2 & 4 & 0,4 & 4 & 8 & 0,04 & 6 \\
\hline $\boldsymbol{h m} \boldsymbol{m} \boldsymbol{B} \boldsymbol{\Delta}-\mathbf{- 0}$ óra & 3 & 0,1 & 2 & 0,3 & 2 & 4 & 0,04 & 2 \\
\hline $\boldsymbol{h} \boldsymbol{m} \boldsymbol{b} \boldsymbol{B}^{+}-\mathbf{- 3}$ óra & 18 & 0,2 & 3 & 0,2 & 3 & 4 & 0,04 & 0,3 \\
\hline $\boldsymbol{h} \boldsymbol{m} \boldsymbol{b} \boldsymbol{B} \boldsymbol{\Delta}-3$ óra & 2 & 0,05 & 0,9 & 0,04 & 0,9 & 0,3 & 0,01 & 0,1 \\
\hline
\end{tabular}

A feltüntetett értékek $100 \mathrm{mg}$ konídium metabolittartalmát mutatják nmol-ban megadva. Az eredmények 3 biológiai párhuzamoson végzett 3 mérés átlagai.

\subsubsection{A micélium sterigmatocisztin-termelésében tapasztalt eltérések}

A hmbBA (HZS.212 és HZS.213) és vad típusú törzsek másodlagos metabolittermelését vékonyréteg-kromatográfiás (TLC) eljárással vizsgáltuk meg (24.A ábra). A vizsgálat során azt találtuk, hogy a deléciós törzsek tenyészeteiben rendkívül nagymértékben lecsökkent a sterigmatocisztin gombatoxin mennyisége, annak teljes hiánya sem zárható ki (Karácsony és mtsai. 2014). A deléciós törzsek mintáiban található, a sterigmatocisztinnel megegyező retenciós faktorú, lila színü sáv feltehetőleg megegyezik azzal a még nem jellemzett metabolittal, melyet már Kato és munkatársai (2003) is megfigyeltek. A hisztidintaggelt HmbB fehérjét kifejező törzs (HZS.352), valamint az N-terminális ( $g f p$ - $h m b B$, HZS.363) és C-terminális (hmbB-gfp, HZS.349) GFP-fúziós fehérjét kifejező törzsek esetében a sterigmatocisztin termelése helyreállt (24.A ábra). Annak érdekében, hogy a deléciós törzseknél tapasztalható sterigmatocisztin-termelésben bekövetkezett csökkenés hátterét kiderítsük, megvizsgáltuk a sterigmatocisztin-szintézisért felelős génklaszter (Yu és mtsai. 2004a) néhány tagjának (aflR klaszter-specifikus transzkripciós faktor (Butchko és mtsai. 1999) valamint az stcO ketoreduktáz és $s t c U$ oxidoreduktáz gének (Yu és mtsai. 
2004a)) kifejeződését "standard curve" kiértékeléssel végzett qRT-PCR vizsgálattal. A $h m b B \Delta$ törzs esetében az aflR, az stcO és stcU gének szignifikánsan megemelkedett kifejeződést mutattak (24.B ábra). A vizsgálat eredményei meglepőek, és nincsenek összhangban a deléciós törzsek sterigmatocisztin-bioszintézisében tapasztalt jelentős visszaeséssel (24.B ábra). Az adatokból következően elmondhatjuk, hogy a HmbB fehérje direkt, vagy indirekt módon represszálja a vizsgált gének kifejeződését. Egy részletesebb transzkriptomikai és metabolomikai vizsgálattal felderíthető lenne, hogy a sterigmatocisztinszintézis mely lépésénél hat a HmbB pozitív módon.

A

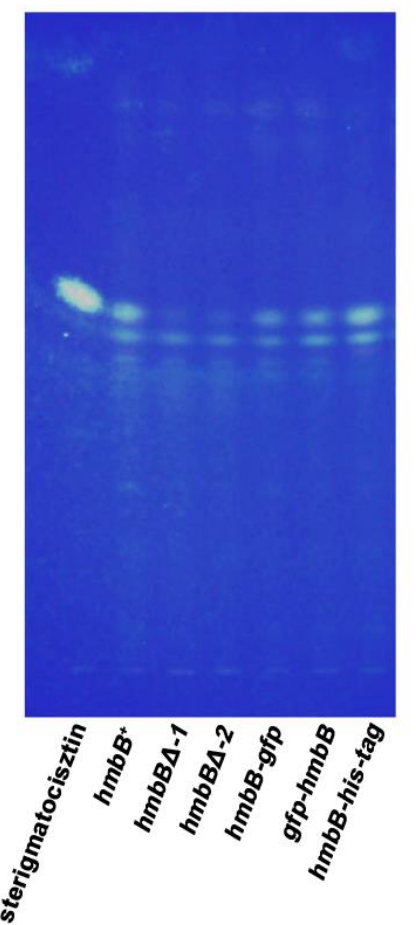

B
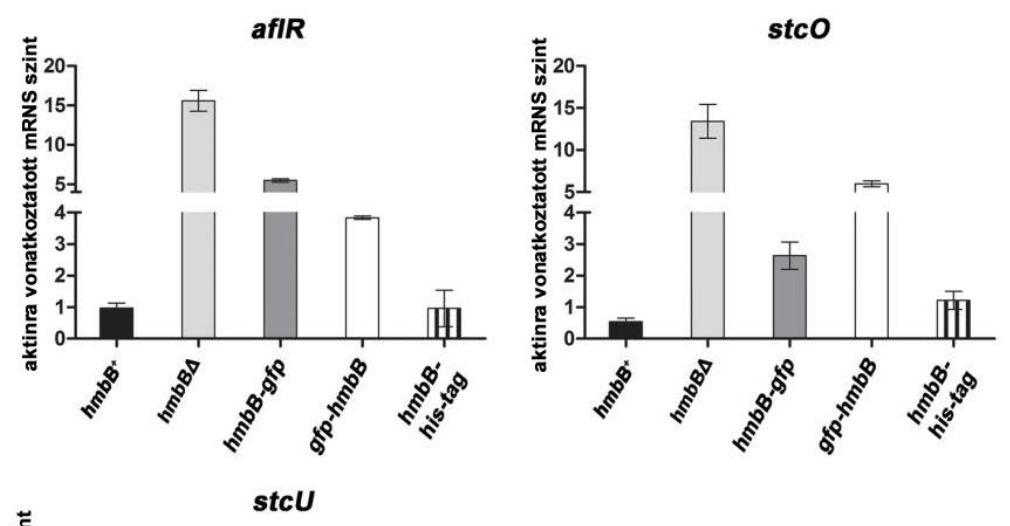

24. ábra: A sterigmatocisztin-termelés és néhány a sterigmatocisztin bioszintézisben résztvevő gén kifejeződésének vizsgálata. A: Másodlagos metabolitok vékonyréteg kromatogramja $\mathrm{hmbB}^{+}$(HZS.120), hmbBA-1 (HZS.212), hmbBA-2 (HZS.213), hmbB-gfp (HZS.349, C-terminális GFP-fúziós fehérjét kifejezö törzs), gfp-hmbB (HZS.363, N-terminális GFP-fúziós fehérjét kifejezö törzs) és hmbB-his-tag (HZS.352, hexahisztidin taggel fúzionált fehérjét kifejező törzs) törzsek mintáiból. B: A sterigmatocisztin-bioszintézishez kapcsolódó aflR, stcO és $s t c U$ gének aktinra vonatkoztatott relatív mRNS-szintjei, $h m b B^{+}$(HZS.120), $h m b B \Delta$ (HZS.212), hmbB-gfp (HZS.349, C-terminális GFP-fúziós fehérjét kifejezö törzs), gfp-hmbB (HZS.363, Nterminális GFP-fúziós fehérjét kifejezö törzs) és hmbB-his-tag (HZS.352, hexahisztidin taggel fuzionált fehérjét kifejezö törzs) törzsekben. Az RNS-mintákat szénforrásként 4\% laktózt tartalmazó folyékony CMtáptalaj felületén 72 óráig, $37^{\circ} \mathrm{C}$-on, rázatás nélkül nevelt micéliumokból izoláltuk. A méréshez felhasznált indítószekvenciákat a III. táblázat tartalmazza. A feltüntetett adatok 3 párhuzamos mérésből lettek számítva a "standard curve" módszer szerint. 


\subsubsection{A sejten belüli lokalizáció kettőssége}

Létrehoztuk a HmbB fehérje C-terminálisához, illetve N-terminálisához fuzionáltatott GFP-t termelö törzseket. A fúziós konstrukciókat a $h m b B$ promóter szekvenciájával együtt a gén eredeti lókuszába juttattuk vissza deléciós törzs transzformálásával. A C-terminális fúziós fehérjét termelö törzs „Western-blot” vizsgálata során 60 kDa és 27 kDa méreteknél detektáltunk GFP-pozitív sávot (25. ábra).

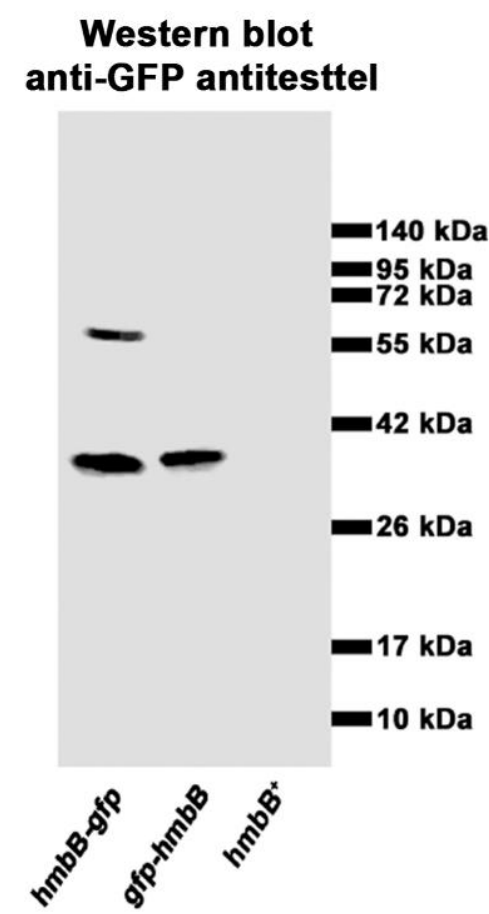

25. ábra: A hmbB-gfp (HZS.349, C-terminális GFP-fúziós fehérjét kifejező törzs), gfp-hmbB (HZS.363, Nterminális GFP-fúziós fehérjét kifejező törzs) és $h m b B^{+}$(HZS.118) törzsek Western-blot vizsgálata. A fúziós fehérjéket anti-GFP antitesttel detektáltuk. A molekulasúlyokat az ábra jobb oldalán tüntettük fel kiloDaltonban.

A 60 kDa-os méret megegyezik a fúziós fehérje számított méretével, a 27 kDa pedig a GFP fehérje méretével. Az utóbbi feltehetőleg a fúziós fehérje degradációjából származhat. Az N-terminális fúziót hordozó fehérje esetében kizárólag a 27 kDa méretben kaptunk jelet. Ez megegyezik azzal a mérettel, melyet a fúziós fehérje feltételezett mitokondriális importszignáljának elhasítása esetén várunk (25. ábra). Ahogy azt a korábbiakban jeleztük, mindkét fúziós fehérjét kifejező törzsben megfigyeltük a $h m b B^{+}$ fenotípus helyreállását a konídiospórák csírázóképességének tekintetében (26.B ábra), valamint a vad típushoz hasonló növekedést tapasztaltunk menadion és hőstressz jelenlétében (Karácsony és mtsai. 2014). Az aszkospórák csírázóképességére vonatkozó deléciós fenotípus azonban érdekes módon egyik GFP-fúziós törzs esetében sem állt helyre (26.D ábra). Mindkét fúziós törzs a vad típushoz hasonló mértékben termelte a 
sterigmatocisztint (24.A ábra) is, miközben mindkét törzs magas szinten fejezte ki az aflR, stc $O$ és $s t c U$ géneket. A mért mRNS-szintek a deléciós és a vad típus esetében mért értékek közé estek (24.B ábra). Az eredmények arra utalnak, hogy a HmbB fehérje két független útvonalon is befolyásolja a sterigmatocisztin termelését. Az aflR, stcO és stcU gének fokozott átíródása a deléciós törzsben független attól a folyamattól, melyben a HmbB esszenciális a toxin termelődéséhez.

A
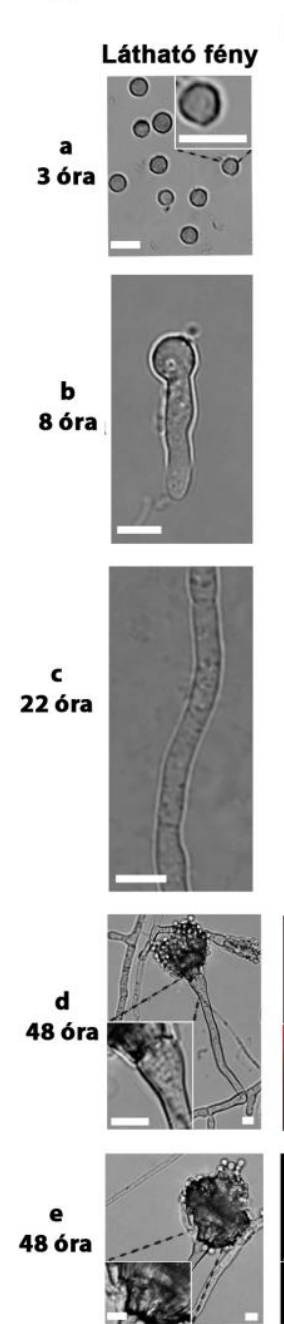
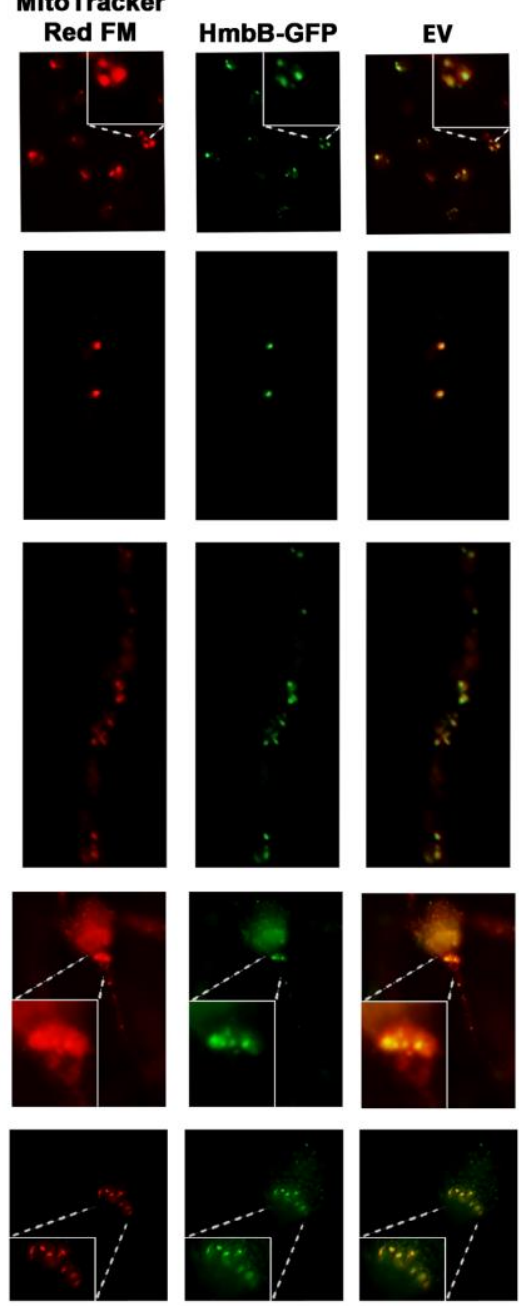

26. ábra: A HmbB-GFP lokalizációja az ivartalan ciklus különböző szakaszaiban. A: A HmbB-GFP (HZS.349) mitokondriális lokalizációja különböző fejlődési fázisokban (a: duzzadó konídiumok, b: csírázó konídium, c: micélium, d és e: konídiofor). A sejtek mitokondriumait Mitotracker Red FM festékkel festettük és fluoreszcens mikroszkóppal vizsgáltuk. B: A HhoA-mRFP (H1 hiszton és „red fluorescent protein” fúziója)

HmbB-GFP törzs (HZS.358) vizsgálata fluoreszcens mikroszkóppal a fejlődés különböző szakaszaiban (f: nyugvó konídiumok, g: duzzadó konídiumok, h: csírázó konídiumok, i és j: micélium). A nyilak sejtmagokat, a nyílhegyek mitokondriumokat jelölnek. A skálák $5 \mu \mathrm{m}$-t jelölnek. EV: a vörös és zöld fluoreszcens felvételek egymásra vetített, kombinált képe. 


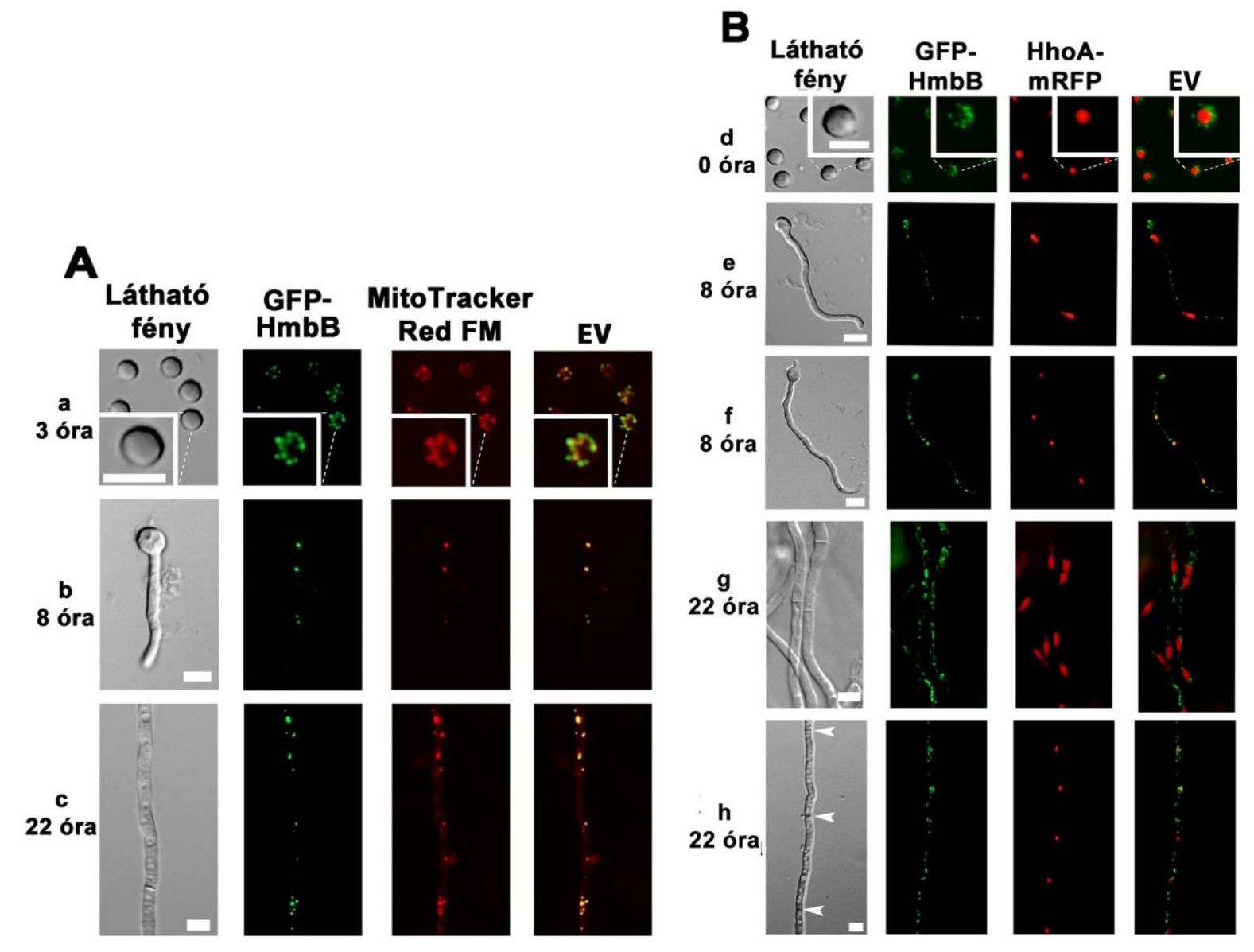

27. ábra: A GFP-HmbB fúziós fehérje sejten belüli elhelyezkedése az ivartalan ciklus különböző szakaszaiban. A: A GFP-HmbB (HZS.363) mitokondriális lokalizációja különböző fejlődési fázisokban (a: duzzadó konídiumok, b: csírázó konídium, c: micélium). A sejtek mitokondriumait Mitotracker Red FM festékkel festettük és fluoreszcens mikroszkóppal vizsgáltuk. B: A HhoA-mRFP (H1 hiszton és „,red fluorescent protein" fúziója) GFP-HmbB törzs (HZS.366) vizsgálata fluoreszcens mikroszkóppal a fejlődés különböző szakaszaiban (d: nyugvó konídiumok, e és f: csírázó konídiumok, g és h: micélium). A szaggatott vonalak a beágyazott képeken kinagyított részleteket jelölik. A feltüntetett skálák $5 \mu \mathrm{m}$ méretet jelölnek. EV: a vörös és zöld fluoreszcens felvételek egymásra vetített, kombinált képe.

Mindkét fúziós fehérje a mitokondriumban lokalizálódik (MitoTracker Red FM festéssel vizsgálva) az aszexuális ciklus összes vizsgált fázisában (26.A ábra: C-terminális GFP fúzió, 27.A ábra: N-terminális GFP fúzió). A tény, hogy mindkét fehérje esetében mitokondriális lokalizációt tapasztaltunk, arra utal, hogy a transzportot követően lehasadó N-terminális szekvencia a mitokondriumban marad. Sejtplazmás lokalizációt nem tapasztaltunk egyik fúziós fehérje esetében sem. A konídiofórokban a HmbB-GFP (Cterminális fúziós fehérje) kolokalizációt mutat a Mitotracker festékkel (26.A ábra). A nyéltől a vezikulum felé haladva a mitokondriumok feldúsulását figyeltük meg a vezikulum disztális részén ( $\mathrm{d}$ panel) és a fialidokban (e panel), viszont a metulák esetében ilyet nem tapasztaltunk. Habár a nem csírázó spórák szabálytalanul festődnek a Mitotracker festékkel, a HmbB-GFP-vel mutatott kolokalizációja egyértelmü a teljes konídiofórban (26.A ábra/d panel). Az izotropikus növekedési fázisban lévő konídiumoknál minden esetben kimutattuk a HmbB fúziós fehérje és a Mitotracker festék kolokalizációját (26.A ábra/a panel, 27.A ábra/a panel). Azokban a törzsekben melyek a $\mathrm{HmbB}$ fúziós fehérje (C- vagy N-terminális 
GFP) mellett a HhoA-mRFP (H1 hiszton-RFP fúzió) fehérjét is termelték, a HmbB fehérje mind a nyugvó, mind az izotropikus növekedésben lévő spórák esetében csak a mitokondriumokban volt megfigyelhető, a sejtmagokban nem (26.B ábra/ f és g panelek, 27.B ábra). Ezzel szemben növekvő gombafonalakban a mitokondriális jelenlét mellett alkalomszerüen megfigyeltük a HmbB fehérje sejtmagi lokalizációját is (26.B ábra/panel h alsó szekció és panel j, 27.B ábra/panel f és h) ami példátlan a gombák világában. A HmbBGFP vagy GFP-HmbB fehérjék sejtmagi előfordulása csoportosan volt megfigyelhető egy adott rendszer szerint. Megfigyeléseink alapján a gombafonalakban egy-egy szeptumokkal határolt kompartmentben a sejtmagok mindegyike, vagy egyike sem tartalmazta a HmbB fúziós fehérjét (26.B ábra). Míg a 26.B ábra „„” paneljén a HmbB hiányzik a micélium sejtmagjaiból, addig a ,j” panelen látható gombafonal középső és alsó kompartmentjében a HmbB-GFP minden sejtmagban megtalálható, a felső kompartmentben viszont nem lokalizálódik a sejtmagban. Az N-terminális fúzió esetében is a sejtmagi megjelenés hasonló, egy-egy kompartmentre korlátozódó mintázatát tapasztaltuk (27.B ábra).

Annak érdekében, hogy egyidőben vizsgálhassuk a HmbB-GFP jelenlétét a mitokondriumban és a sejtmagban, a mintákat kombinált DAPI/MitoTracker Red FM festéssel kezeltük. A DAPI a sejtek DNS-tartalmát (sejtmagi és mitokondriális), a Mitotracker pedig a mitokondriumokat teszi láthatóvá. A vizsgálat eredményeként a HmbBGFP fehérje jellemzően a mitokondriumban, ritkán a sejtmagban fordult elő (28. ábra).

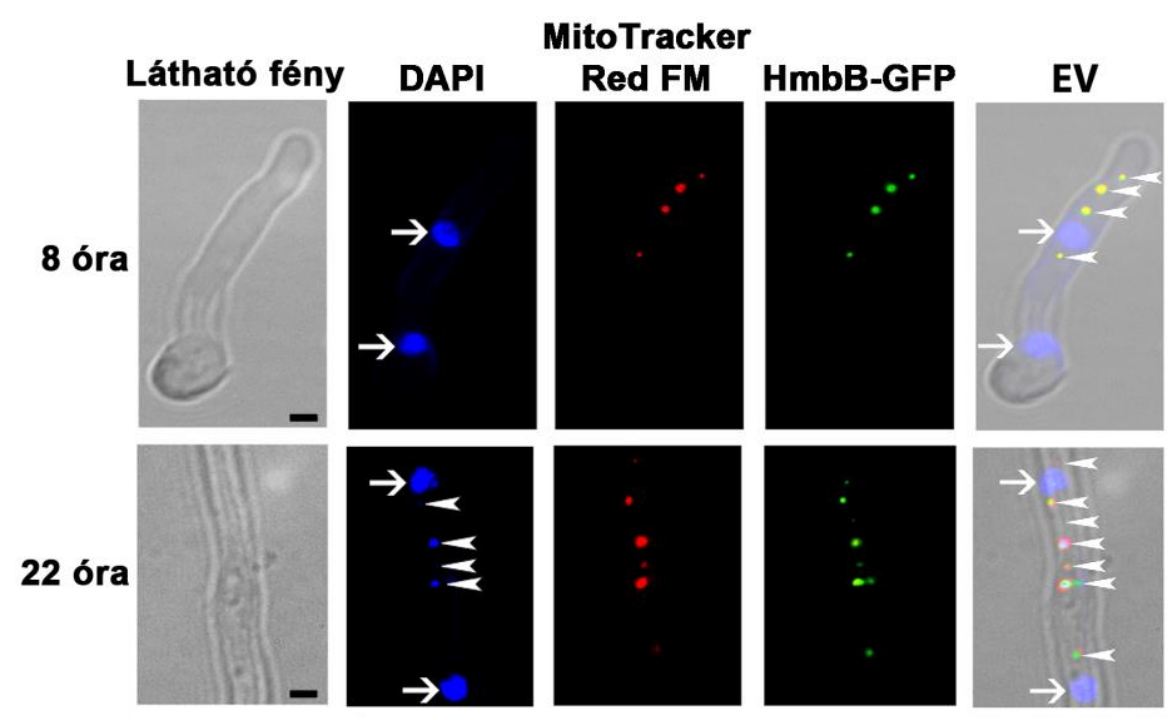

28. ábra: A HmgB-GFP, a DNS (DAPI) és a mitokondriumok (Mitotracker Red FM) sejten belüli lokalizációja fiatal hifában ( 8 óra) és micéliumban (22 óra) HZS.349 törzsben vizsgálva. Mindkét panel a HmbB mitokondriális lokalizációját mutatja. A DAPI esetenként a mitokondriumok DNS-tartalmát is megfesti (alsó panel). A nyilak a sejtmagokat, a nyílhegyek a mitokondriumokat jelölik. A skála $2 \mu \mathrm{m}$ méretet jelöl. EV: a kék, vörös és zöld fluoreszcens felvételek egymásra vetített, kombinált képe. 
Mivel a HmbB-GFP fúziós konstrukciók nem állították helyre a deléciós mutáns aszkospóráinak csírázóképességét, megvizsgáltuk a fúziós fehérjék jelenlétét a $h m b B$-gfp és gfp-hmbB törzsek homozigóta keresztezéseiből származó aszkospórákban. A fúziós fehérjét detektáltuk a Hülle-sejtek mitokondriumaiban, azonban az éretlen és érett aszkospórákban csak elvétve figyeltük meg (29. ábra). Az aszkospórák közül a fluoreszcenciát mutatók aránya megközelítőleg megegyezett a csírázóképes aszkospórák arányával (26.D ábra).
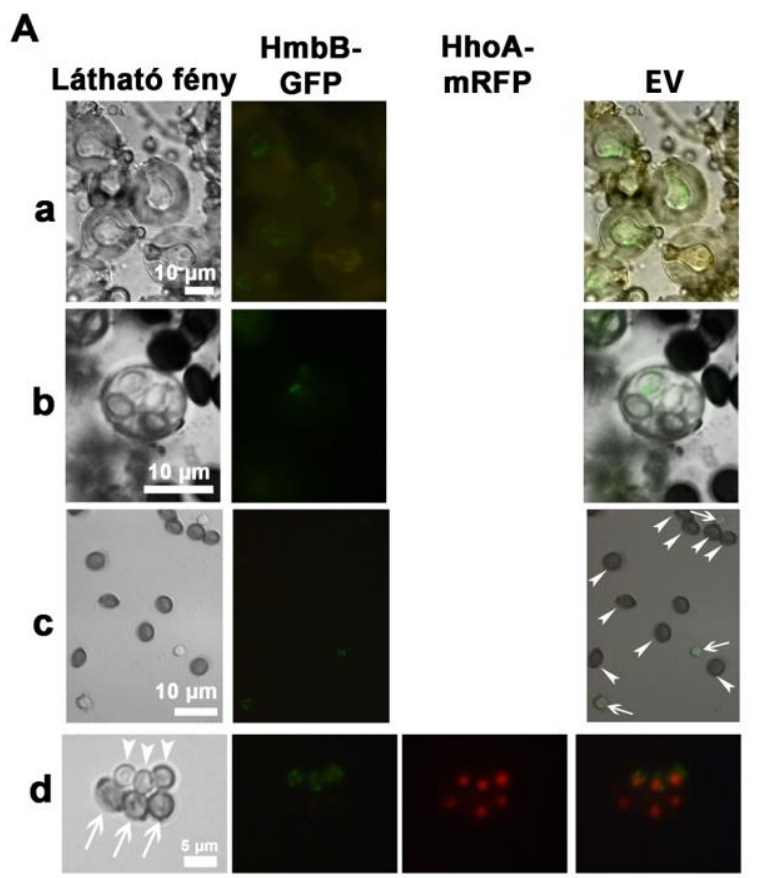

B

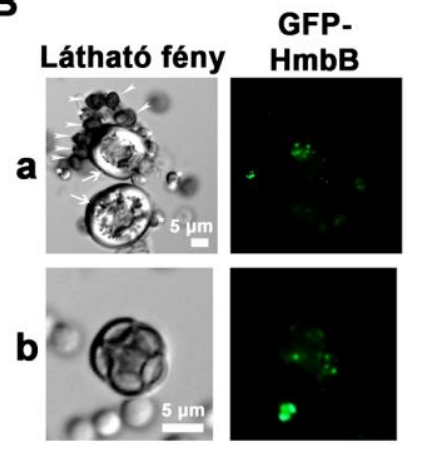

HhoA-
mRFP

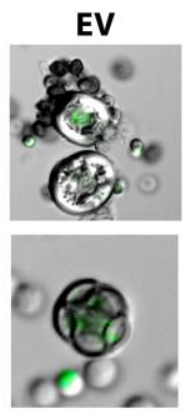

c
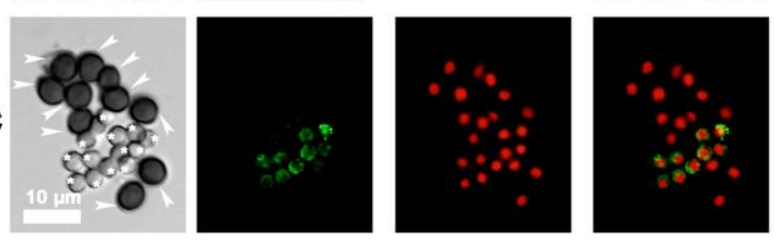

29. ábra: A HmbB-GFP és GFP-HmbB fehérjék lokalizációja a szexuális struktúrákban. A: A HmbB-GFP lokalizációja a Hülle-sejtekben (a), fiatal aszkospórákban (b) és érett aszkospórákban (c) a HZS.349 törzsben. A HmbB-GFP-t az aszkospórák az alacsony csírázóképességnek megfelelő arányban tartalmazták (mint a GFP-

HmbB esetében). A nyilak konídiumokat, a nyílhegyek aszkospórákat jelölnek. A d képsorozaton a ,red fluorescent protein"-H1 hiszton és HmbB-GFP fúziós fehérjéket kifejező HZS.358 törzs aszkospórái és konídiumai láthatók, bemutatva a HmbB-GFP hiányát az aszkospórákban. A nyilak aszkospórákat, a nyílhegyek konídiumokat jelölnek. B: A GFP-HmbB lokalizációja a Hülle-sejtekben (a) és fiatal aszkospórákban (b) a HZS.363 törzsben. A GFP-HmbB ritka előfordulását az aszkospórákban a „red fluorescent protein"-H1 hiszton és GFP-HmbB fúziós fehérjéket kifejező HZS.366 törzs konídiumairól és aszkospóráiról készült fotók szemléltetik (c). A nyilak Hülle-sejteket, a nyílhegyek aszkospórákat, a csillagok

konídiumokat jelölnek. EV: a vörös és zöld fluoreszcens felvételek egymásra vetített, kombinált képe. A

kleisztotéciumok a HZS.349, HZS.358, HZS.363 és HZS.366 törzsek homozigóta kereszteződéseiből származtak. A mintákat fluoreszcens mikroszkóppal vizsgáltuk (Zeiss 15 szürőszett GFP és Zeiss 09 szürőszett mRFP esetén). 


\subsubsection{A mtDNS-kópiaszámban és mitokondriális transzkripcióban tapasztalt eltérések}

Összehasonlítottuk a $h m b B^{+}$és $h m b B \Delta$ törzsek mitokondriális DNS-tartalmát. Ennek érdekében qRT-PCR (quantitative Real Time PCR) eljárással mértük meg a törzsek DNSkivonataiban az $n d h B$ (NADH-dehidrogenáz II alegység) és oxiB (citokróm c-oxidáz II alegység) mitokondriális gének mennyiségét a sejtmagban kódolt kontrollhoz (actA, $\gamma$-aktin) viszonyítva. Az adatok kiértékeléséhez a „standard curve” eljárást használtuk, ezért az adatok a mtDNS-kópiaszámot mutatják a sejtmagi DNS-kópiaszámára vonatkoztatva a különböző mintákban, melyek egymással összevethetőek és azok a valóságos kópiaszám viszonyokat tükrözik. A vizsgálatot izotropikus növekedésben lévő konídiumokon (3 óra inkubáció) és micélumokon (22 óra inkubáció) is elvégeztük. Annak érdekében, hogy homogén (a nem csírázó spóráktól mentes) micéliummal dolgozhassunk a hmbBA törzs esetében, a nem csírázó spórákat előzőleg eltávolítottuk a tenyészetből (lásd 4.2.3. fejezet), majd további 22 órán át inkubáltuk (30. ábra).

A
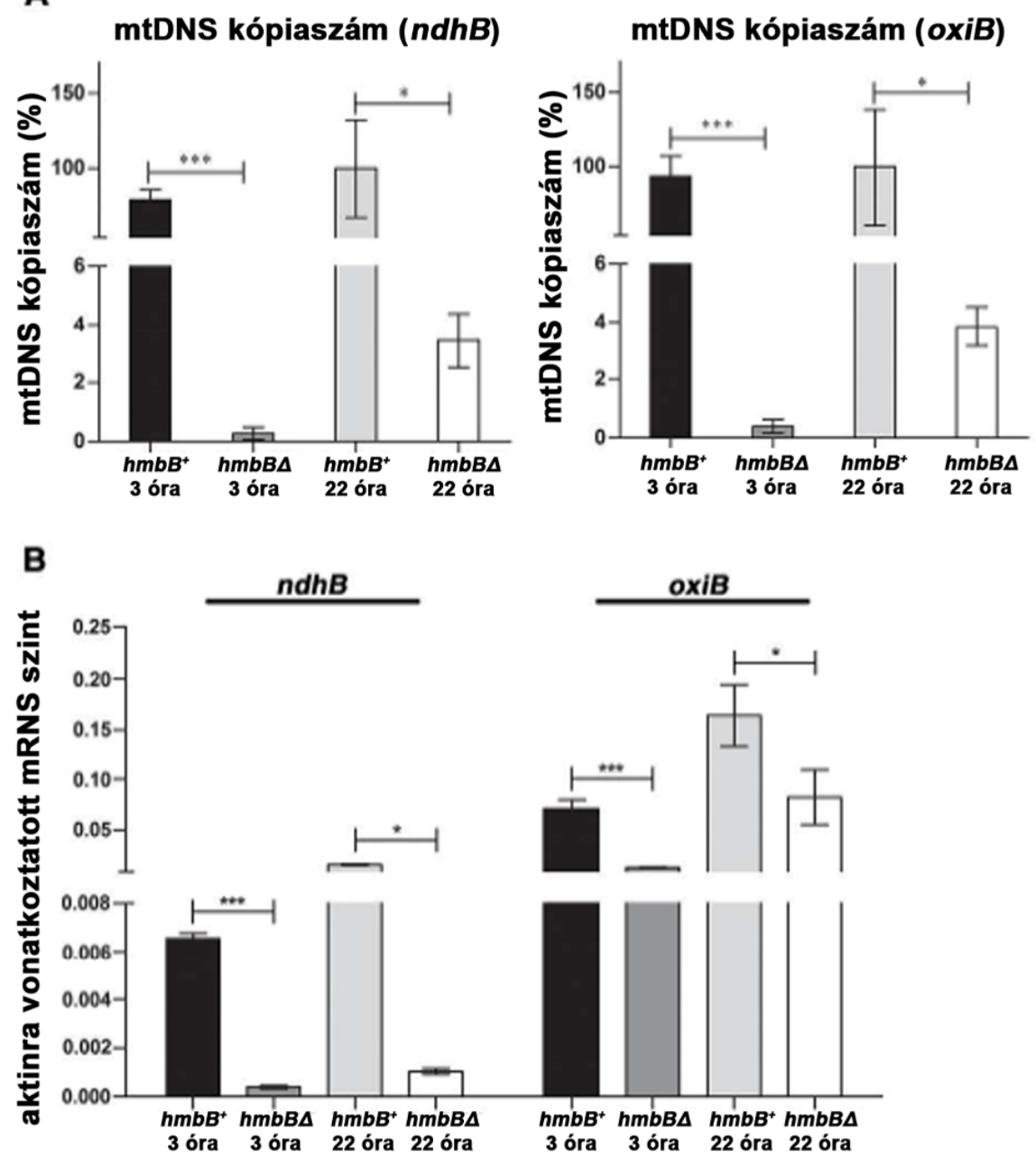

30. ábra: A mtDNS kópiaszáma és a mtDNS kifejeződése duzzadó konídiumokban (3 óra) és micéliumokban (22 óra) $h m b B^{+}$és $h m b B \Delta$ törzsekben vizsgálva. A: a $h m b B^{+}$törzs esetében mért értékre 
normalizált mtDNS-tartalom $n d h B$ és $o x i B$ mitokondriális gének mérésével. B: az $n d h B$ és $o x i B$ gének relatív mRNS-szintjei. Belső kontrollnak a $\gamma$-aktin $(a c t A)$ gént használtuk minden mérésnél. Három ismételt mérésből származó szórásokat tüntettünk fel. A szignifikanciákat csillagokkal jelöltük $(* p<0,05 ; * * * p<0,0005)$. A konídiumokat HZS.120 ( $\left.h m b B^{+}\right)$és HZS.212 ( $h m b B$ ) törzsekről gyüjtöttük be, és 3 óráig inkubáltuk MMtápoldatban. A HZS.212 törzs 22 órás mintáit a csírázóképes konídiumfrakcióból neveltük (lásd 4.2.3. fejezet). Hasonló eredményeket kaptunk a HZS.213 törzs esetében is.

A $h m b B \Delta$ törzs duzzadó konídiumaiban a mitokondriális DNS mennyiségének drasztikus csökkenését (>99 \%) mértük az azonos ideig inkubált $h m b B^{+}$törzshöz viszonyítva (30.A ábra 3h). Ez az érték teljes mértékben korrelál a spórák esetében tapasztalt, nagymértékben lecsökkent csírázóképességgel (1\% alatti csírázóképesség). A két független deléciós transzformáns (HZS.212 és HZS.213) estében közel megegyező értékeket mértünk. A csírázó konídiumok 22 órás inkubálását követően a mitokondriális DNS kópiaszáma a deléciós törzsben a $h m b B^{+}$törzs esetében mért érték 4\%-ának adódott. Meglepő, hogy a $h m b B \Delta$ micélumok ilyen alacsony mitokondriális DNS-tartalom mellett is képesek növekedni, fejlődni és konídiumokat képezni. Az ellentmondás feloldása érdekében qRT-PCR eljárással vizsgáltuk meg az $n d h B$ és oxiB gének kifejeződését. Az A. nidulans mitokondriumában egy policisztronos mRNS az oxiB mellett 3 másik fehérjét kódoló gént (oxiA, $n d h C$, és atp9) tartalmaz, míg az $n d h B$ szekvencia egy másik mRNS-en kódolt (NCBI Reference Sequence: NC_017896.1), így méréseink két független mitokondriális transzkriptumról nyert adatokon alapulnak. A 30.B ábrán megfigyelhető, hogy bár az $n d h B$ és $o x i B$ mRNS-ek mennyisége alacsonyabb a $h m b B^{+}$törzshöz viszonyítva, ezen eltéréseknek a mértéke nem azonos a mitokondriális DNS kópiaszámban kimutatott eltéréssel. A $h m b B^{+}$ és $h m b B \Delta$ törzsek mitokondriális DNS-kópiaszámában tapasztalt nagymértékü különbség csak mérsékelt formában jelentkezett a mitokondriális DNS-ről átíródott mRNS-ek szintjén. A két független deléciós transzformáns (HZS.212 és HZS.213) esetében közel megegyező értékeket mértünk. A mitokondriális DNS-kópiaszám lecsökkenésének a kódolt mRNS-ek mennyiségében megmutatkozó mérsékelt hatását alátámasztja a deléciós törzs $h m b B^{+}$ törzzsel megegyező respirációs értéke mind a duzzadó spórákban, mind pedig a micéliumban (lásd 5.3.4.10.4. fejezet).

\subsubsection{A HmbB fehérje redox folyamatokra gyakorolt hatásának részletes vizsgálata}

Mivel a $h m b B \triangle$ törzsek érzékenysége menadionra és diamidra jelentősen eltért a $h m b B^{+}$törzsekhez képest, ezért részletesebben megvizsgáltuk a deléciós és a kontroll törzs intracelluláris redox környezetét, és vizsgáltuk a mért paraméterek értékeinek változását menadion- és diamidstressz fennállásakor (VI. táblázat). 
VI. táblázat: A redox környzethez kapcsolódó molekulák és enziaktivitások.

\begin{tabular}{|c|c|c|c|c|c|c|c|c|}
\hline & \multicolumn{2}{|c|}{$\begin{array}{l}\text { kezeletlen konídium } \\
\text { (3 óra) }\end{array}$} & \multicolumn{2}{|c|}{$\begin{array}{l}\text { kezeletlen micélium } \\
\text { (36 óra) }\end{array}$} & \multicolumn{2}{|c|}{$\begin{array}{c}\text { menadionnal kezelt } \\
\text { micélium } \\
\text { (30+6óra) }\end{array}$} & \multicolumn{2}{|c|}{$\begin{array}{c}\text { diamiddal kezelt } \\
\text { micélium } \\
\text { (30+6 óra) }\end{array}$} \\
\hline & $h m b B^{+}$ & hmbBA & $h m b B^{+}$ & $h m b B A$ & $h m b B^{+}$ & $h m b B A$ & $h m b B^{+}$ & $h m b B A$ \\
\hline GR & $\begin{array}{c}76 \\
\pm 31\end{array}$ & $\begin{array}{c}65 \\
\pm 25\end{array}$ & $\begin{array}{c}37 \\
\pm 7,6\end{array}$ & $\begin{array}{c}44 \\
\pm 12\end{array}$ & $\begin{array}{r}148 \\
\pm 45\end{array}$ & $\begin{array}{c}374 \\
\pm 93 *\end{array}$ & $\begin{array}{c}26 \\
\pm 4,4\end{array}$ & $\begin{array}{c}16,4 \\
\pm 2,9 *\end{array}$ \\
\hline GPx & $\begin{array}{c}91 \\
\pm 8,8\end{array}$ & $\begin{aligned} & 27 \\
\pm & 12 * *\end{aligned}$ & $\begin{array}{c}47 \\
\pm 11\end{array}$ & $\begin{array}{c}45 \\
\pm 12\end{array}$ & $\begin{array}{r}123 \\
\pm 31\end{array}$ & $\begin{array}{l}238 \\
\pm 55\end{array}$ & $\begin{array}{c}22 \\
\pm 1,9\end{array}$ & $\begin{array}{c}22 \\
\pm 2,8\end{array}$ \\
\hline GST & $\begin{array}{c}15 \\
\pm 1,5\end{array}$ & $\begin{array}{c}19 \\
\pm 2,3\end{array}$ & $\begin{array}{l}4,8 \\
\pm 1\end{array}$ & $\begin{array}{c}8,2 \\
\pm 1,1 *\end{array}$ & $\begin{array}{c}13 \\
\pm 1,9\end{array}$ & $\begin{aligned} & 70 \\
\pm & 12 * *\end{aligned}$ & $\begin{array}{c}5,4 \\
\pm 1,2\end{array}$ & $\begin{array}{c}16 \\
\pm 3,9 *\end{array}$ \\
\hline G6PD & $\begin{array}{r}2810 \\
\pm 603\end{array}$ & $\begin{array}{l}644 \\
\pm 81 * *\end{array}$ & $\begin{array}{c}831 \\
\pm 154\end{array}$ & $\begin{array}{l}2930 \\
\pm 737 *\end{array}$ & $\begin{array}{l}1876 \\
\pm 246\end{array}$ & $\begin{array}{r}1840 \\
\pm 410\end{array}$ & $\begin{array}{r}3718 \\
\pm 274\end{array}$ & $\begin{array}{c}2859 \\
\pm 512^{*}\end{array}$ \\
\hline SOD & $\begin{array}{l}492 \\
\pm 67\end{array}$ & $\begin{aligned} & 145 \\
\pm & 14 * * *\end{aligned}$ & $\begin{array}{l}215 \\
\pm 51\end{array}$ & $\begin{array}{c}406 \\
\pm 51 *\end{array}$ & $\begin{array}{c}1209 \\
\pm 9\end{array}$ & $\begin{aligned} & 922 \\
\pm & 168 *\end{aligned}$ & $\begin{array}{c}676 \\
\pm 173\end{array}$ & $\begin{array}{l}524 \\
\pm 97\end{array}$ \\
\hline CAT & $\begin{array}{c}241 \\
\pm 6\end{array}$ & $\begin{array}{c}33 \\
\pm 3 * * *\end{array}$ & $\begin{array}{l}1230 \\
\pm 75\end{array}$ & $\begin{array}{c}562 \\
\pm 38^{*}\end{array}$ & $\begin{array}{l}458 \\
\pm 43\end{array}$ & $\begin{array}{l}414 \\
\pm 34\end{array}$ & $\begin{array}{l}415 \\
\pm 30\end{array}$ & $\begin{array}{l}303 \\
\pm 21\end{array}$ \\
\hline össz. glutation & $\begin{array}{c}68 \\
\pm 21\end{array}$ & $\begin{array}{c}47 \\
\pm 11\end{array}$ & $\begin{array}{c}56 \\
\pm 11\end{array}$ & $\begin{array}{c}106 \\
\pm 16^{*}\end{array}$ & $\begin{array}{c}21 \\
\pm 1,9\end{array}$ & $\begin{array}{c}56 \\
\pm 16^{*}\end{array}$ & $\begin{array}{c}18 \\
\pm 2,2\end{array}$ & $\begin{array}{c}139 \\
\pm 36^{*}\end{array}$ \\
\hline GSSG & $\begin{array}{c}6,1 \\
\pm 2,2\end{array}$ & $\begin{array}{c}0,3 \\
\pm 0,2^{*}\end{array}$ & $\begin{array}{c}2,1 \\
\pm 0,2\end{array}$ & $\begin{array}{c}9,3 \\
\pm 0,9 * * *\end{array}$ & $\begin{array}{c}0,5 \\
\pm 0,01\end{array}$ & $\begin{array}{c}11 \\
\pm 2,4^{*}\end{array}$ & $\begin{array}{c}2,4 \\
\pm 0,6\end{array}$ & $\begin{array}{c}8,4 \\
\pm 1,5^{*}\end{array}$ \\
\hline összes tiol & $\begin{array}{l}1160 \\
\pm 265\end{array}$ & $\begin{array}{r}1063 \\
\pm 112\end{array}$ & $\begin{array}{l}117 \\
\pm 25\end{array}$ & $\begin{array}{l}126 \\
\pm 11\end{array}$ & $\begin{array}{l}879 \\
\pm 66\end{array}$ & $\begin{array}{c}253 \\
\pm 43^{* * *}\end{array}$ & $\begin{array}{c}648 \\
\pm 138\end{array}$ & $\begin{array}{c}451 \\
\pm 118\end{array}$ \\
\hline össżes ROS & $\begin{array}{l}350 \\
\pm 56\end{array}$ & $\begin{array}{l}250 \\
\pm 9 *\end{array}$ & $\begin{array}{l}178 \\
\pm 10\end{array}$ & $\begin{array}{r}193 \\
\pm 51\end{array}$ & $\begin{array}{l}128 \\
\pm 15\end{array}$ & $\begin{array}{l}412 \\
\pm 39\end{array}$ & $\begin{array}{l}271 \\
\pm 67\end{array}$ & $\begin{array}{l}244 \\
\pm 26\end{array}$ \\
\hline szuperoxid & $\begin{array}{r}403 \\
\pm 56\end{array}$ & $\begin{array}{c}274 \\
\pm 19^{*}\end{array}$ & $\begin{array}{l}223 \\
\pm 29\end{array}$ & $\begin{array}{c}403 \\
\pm 33^{* *}\end{array}$ & $\begin{array}{l}367 \\
\pm 31\end{array}$ & $\begin{array}{c}295 \\
\pm 50^{* * *}\end{array}$ & $\begin{array}{l}343 \\
\pm 22\end{array}$ & $\begin{array}{l}311 \\
\pm 33\end{array}$ \\
\hline NADPH & $\begin{array}{l}39,0 \\
\pm 1,6\end{array}$ & $\begin{array}{l}43,2 \\
\pm 4,0\end{array}$ & $\begin{array}{l}152,2 \\
\pm 13,9\end{array}$ & $\begin{array}{c}109,9 \\
\pm 3,6^{* *}\end{array}$ & NA & NA & NA & NA \\
\hline NADP & $\begin{array}{c}1,0 \\
\pm 0,32\end{array}$ & $\begin{array}{c}7,9 \\
\pm 0,3 \text { *** }\end{array}$ & $\begin{array}{c}9,9 \\
\pm 2,1\end{array}$ & $\begin{array}{c}31,6 \\
\pm 12,7^{*}\end{array}$ & NA & NA & NA & NA \\
\hline
\end{tabular}

A menadionnal kezelt micéliumokat 30 óráig növesztettük $\mathrm{MM}+$ paba tápoldatban, majd a tápoldatot $0,8 \mathrm{mM}$ menadionnal kiegészítve a tenyészetet további 6 óráig inkubáltuk. A diamiddal kezelt micéliumokat 30 óráig inkubáltuk $\mathrm{MM}+$ paba tápoldatban, majd a tápoldatot $1,8 \mathrm{mM}$ diamiddal kiegészítve további 6 óráig inkubáltuk

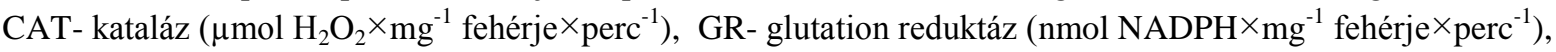

GPx- glutation peroxidáz (nmol NADPH $\times \mathrm{mg}^{-1}$ fehérje $\times$ perc $^{-1}$ ), GST- glutation-S-transzferáz (nmol GS-

$\mathrm{DNB} \times \mathrm{mg}^{-1}$ fehérje $\times$ perc $\left.^{-1}\right)$, G6PD- glükóz-6-P dehidrogenáz $\left(\mathrm{nmol}\right.$ NADPH $\times \mathrm{mg}^{-1}$ fehérje $\times$ perc $\left.^{-1}\right)$, SODszuperoxid dizmutáz (unit $\times \mathrm{mg}^{-1}$ fehérje), összes glutation ( $\mu$ mol $\times \mathrm{g}^{-1}$ száraztömeg), GSSG $\left(\mu \mathrm{mol} \times \mathrm{g}^{-1}\right.$ száraztömeg), összes tiol ( $\mu$ mol $\times \mathrm{g}^{-1}$ száraztömeg), összes ROS (pmol diklorofluoreszcein $\times \mathrm{mg}^{-1}$ fehérje), szuperoxid ( $\mathrm{pmol}^{\circ} \mathrm{mg}^{-1}$ fehérje), NADPH (nmol $\times \mathrm{g}^{-1}$ száraztömeg), NADP (nmol $\times \mathrm{g}^{-1}$ száraztömeg), NA: nincs adat. Minden mérést háromszor végeztünk el. A $h m b B \Delta$ (HZS.212) és $h m b B^{+}$(HZS.118) minták közti különbségek szignifikanciáját csillagokkal jelöltük $(* \mathrm{p}<0,05 ; * * \mathrm{p}<0,005$; *** $\mathrm{p}<0,0005)$.

5.3.4.10.1. A $h m b B$ deléció hatása a redox állapotra izotropikus növekedésben lévő konídiumokban és micéliumban

A $h m b B \Delta$ és $h m b B^{+}$törzsek belső redox környezetének tanulmányozásához megvizsgáltuk a gombasejtek oxidált glutation (GSSG), összes glutation (GSH+GSSG), 
összes tiol, valamint NADPH és NADP tartalmát. Annak érdekében, hogy a vad típusú és a deléciós törzs ROS-tartalmáról képet kapjunk, megmértük a szuperoxid és az összes ROS mennyiségét is.

Az VI. táblázatban feltüntetett eredmények szerint a $h m b B \Delta$ konídiumokban az oxidált glutation (GSSG) mennyisége 20,3-szor kevesebb $(\mathrm{p}<0,05)$ volt, míg az összes glutation mennyisége szignifikánsan nem különbözött a $h m b B^{+}$konídiospórákban mért értéktől (68 és $47 \mu \mathrm{mol} \mathrm{g}{ }^{-1}$ száraztömeg). A deléciós törzsben mért GSSG és össz glutation érték arra utal, hogy a deléciós törzs konídiumaira reduktívabb belső környezet jellemző (Karácsony és mtsai. 2015). Az összes ROS mennyisége 1,4-szer alacsonyabb $(\mathrm{p}<0,05)$ volt a hmbBA konídiumokban, mely elsősorban a deléciós spórák alacsonyabb szuperoxidtartalmának tudható be (403 a 274 pmol $\mathrm{mg}^{-1}$ mennyiséggel szemben). A NADPH mennyisége nem különbözött a $h m b B^{+}$és $h m b B \Delta$ konídiumokban, a NADP mennyisége azonban 7,9-szer magasabbnak $(\mathrm{p}<0,0005)$ bizonyult a deléciós törzs esetében. A $h m b B \Delta$ konídiumokban a GPx, G6PD és SOD enzimek aktivitása 3,4; 4,4 és 3,4-szeresével csökkent $(\mathrm{p}<0,005)$ a $h m b B^{+}$konídiumokhoz képest. A CAT aktivitás 7,3-szor alacsonyabbnak ( $\mathrm{p}<0,0005)$ bizonyult a $h m b B \Delta$ konídiumaiban a $h m b B^{+}$konídiumaihoz képest. (Az eredmények diszkussziója a 6.5. fejezetben történik.)

A mutáns törzs micéliumában az oxidált glutation mennyisége 4,4-szer $(\mathrm{p}<0,0005)$, az összes glutation mennyisége pedig 1,9-szer $(\mathrm{p}<0,05)$ magasabb volt a $h m b B^{+}$törzshöz képest (VI. táblázat). Az összes ROS mennyisége nem különbözött a $h m b B \Delta$ és $h m b B^{+}$ törzsekben, azonban a szuperoxid-tartalom 1,8-szor magasabbnak $(\mathrm{p}<0,005)$ bizonyult a hmbBA törzs esetében. A NADPH mennyisége 1,4-szer alacsonyabb $(\mathrm{p}<0,005)$, a NADP mennyisége 3,2-szer magasabb $(\mathrm{p}<0,05)$ volt a $h m b B \Delta$ micéliumokban a $h m b B^{+}$törzshöz viszonyítva. A GST, G6PD és SOD enzimek aktivitása 1,7; 3,5 és 1,8-szor volt magasabb $(\mathrm{p}<0,05)$ a $h m b B \Delta$ micéliumokban, mint a $h m b B^{+}$micéliumokban. A CAT-aktivitás 2,1-szer volt alacsonyabb $(\mathrm{p}<0,05)$ a $h m b B \Delta$ micéliumokban a vad típushoz képest. (Az eredmények értékelése a 6.5. fejezetben történik.)

\subsection{A menadion és diamid hatása a $h m b B \Delta$ micéliumok redox állapotára}

$\mathrm{Az}$ 5.3.4.10.1. fejezetben bemutatott eredmények arra utalnak, hogy a $h m b B \Delta$ micéliumok endogén eredetű oxidatív stressznek lehetnek kitéve. Ennek alapján felmerül a kérdés, hogy a deléciós törzs vajon képes-e az indukált oxidatív stresszhez adaptálódni. A $h m b B \Delta$ és $h m b B^{+}$törzsek oxidatív stresszre adott válaszát menadion- és diamid-kezeléseket 
követően vizsgáltuk. A stresszágensek koncentrációit a szakirodalomban az A. nidulans oxidatív stresszvizsgálatai során használt értékekre állítottuk be $(0,8 \mathrm{mM}$ menadion és 1,8 $\mathrm{mM}$ diamid), így lehetővé vált eredményeink értékelése a már meglévő fiziológiai, transzkriptomikai és proteomikai tanulmányok kontextusában is (Pócsi és mtsai. 2005, Pusztahelyi és mtsai. 2011).

Az VI. táblázatban bemutatott adatok szerint a $0,8 \mathrm{mM}$ menadionnal történő kezelés hatására a $\mathrm{hmbB}^{+}$micéliumokban a szuperoxid mennyisége 1,6 -szorosára nőtt $(\mathrm{p}<0,005)$, az összes ROS szintje 1,4-szeresével csökkent, míg a ROS-semlegesítő enzimek aktivitásai 2,35,6-szoros emelkedést mutattak (GR: $p<0,05$; GPx: $p<0,05$; GST: $p<0,005$; G6PD: $p<0,005$; SOD: $\mathrm{p}<0,005)$. Az összes glutation mennyisége 2,6-szorosával $(\mathrm{p}<0,005)$, a GSSG szintje pedig 4,2-szeresével $(\mathrm{p}<0,005)$ csökkent a $h m b B^{+}$törzs esetében. A hmbBA micéliumokban a menadion hatására a szuperoxid mennyisége lecsökkent (1,4-szeres, $\mathrm{p}<0,05)$, az összes ROS mennyisége viszont megduplázódott (2,1-szeres, $\mathrm{p}<0,005)$. A vizsgált enzimaktivitások terén a GR- és GST-aktivitás a 8,5-szeresére növekedett ( $\mathrm{p}<0,005$ és $\mathrm{p}<0,0005), 5,3$ és 2,3-szoros növekedést tapasztaltunk a GPx $(\mathrm{p}<0,0005)$ és $\operatorname{SOD}(\mathrm{p}<0,005)$ aktivitásban, valamint 1,6-szeres csökkenést mértünk a G6PD $(\mathrm{p}<0,005)$ aktivitásban. A összes glutation mennyisége a hmbBA micéliumokban 1,9-szeresével csökkent $(\mathrm{p}<0,005)$, míg a GSSG mennyisége nem változott. Mindezen eredmények szerint a menadionnal kezelt hmbBA micéliumok nagyobb mértékü oxidatív stressznek vannak kitéve, mint a menadionnal kezelt $\mathrm{hmbB}^{+}$micéliumok. (Az eredmények diszkussziója a 6.5. fejezetben történik.)

Az 1,8 $\mathrm{mM}$ diamiddal történő kezelés a $h m b B^{+}$micéliumokban az összes glutation 3,1-szeres csökkenését ( $\mathrm{p}<0,005)$, a G6PD és SOD enzimaktivitások 4,5 és 3,1-szeres növekedését $(\mathrm{p}<0,05$ és $\mathrm{p}<0,0005)$ eredményezte. A diamid-kezelés hatására $h m b B \Delta$ micéliumokban a ROS-semlegesítő GR és GPx enzimaktivitások 2,7 és 2-szeres csökkenést $(\mathrm{p}<0,05)$, a GST-aktivitás 2-szeres növekedést $(\mathrm{p}<0,05)$ mutatott, míg - kissé meglepő módon - az összes glutation mennyisége nem változott. Ennek magyarázata lehet, hogy a hmbB $\triangle$ micéliumokban meglévő endogén oxidatív stressz folyamatosan indukált állapotban tartja a glutation szintéziséért felelős enzimeket.

$\mathrm{Az}$ eredmények összességében eredmények arra utalnak, hogy míg a $h m b B^{+}$ micélium oxidatív stressznek van kitéve, addig a $h m b B \Delta$ micéliumban bizonyos mértékig 
csökkent az endogén oxidatív stressz a diamid-kezelés hatására (Karácsony és mtsai. 2015). (Az eredmények diszkussziója a 6.5. fejezetben történik.)

5.3.4.10.3. A HmbB hiányában megváltozik a redox homeosztázisban szerepet játszó gének és stresszválaszgének transzkripciós profilja.

Az A. nidulans oxidatív stresszválaszának és glutationrendszerének transzkriptomikai és proteomikai tanulmányozása során (Pócsi és mtsai. 2005, Pusztahelyi és mtsai. 2011, Sato és mtsai. 2009) számos, az oxidatív stresszválaszban és a belső redoxállapot fenntartásában kulcsfontosságú gént és fehérjét azonosítottak. Ezek közül a gének közül néhányat jelen munkánkban is megvizsgáltunk. Az aktinra vonatkoztatott relatív kifejeződések mértékét a 31. ábra mutatja be. 


\section{glutation-S-transzferázok}
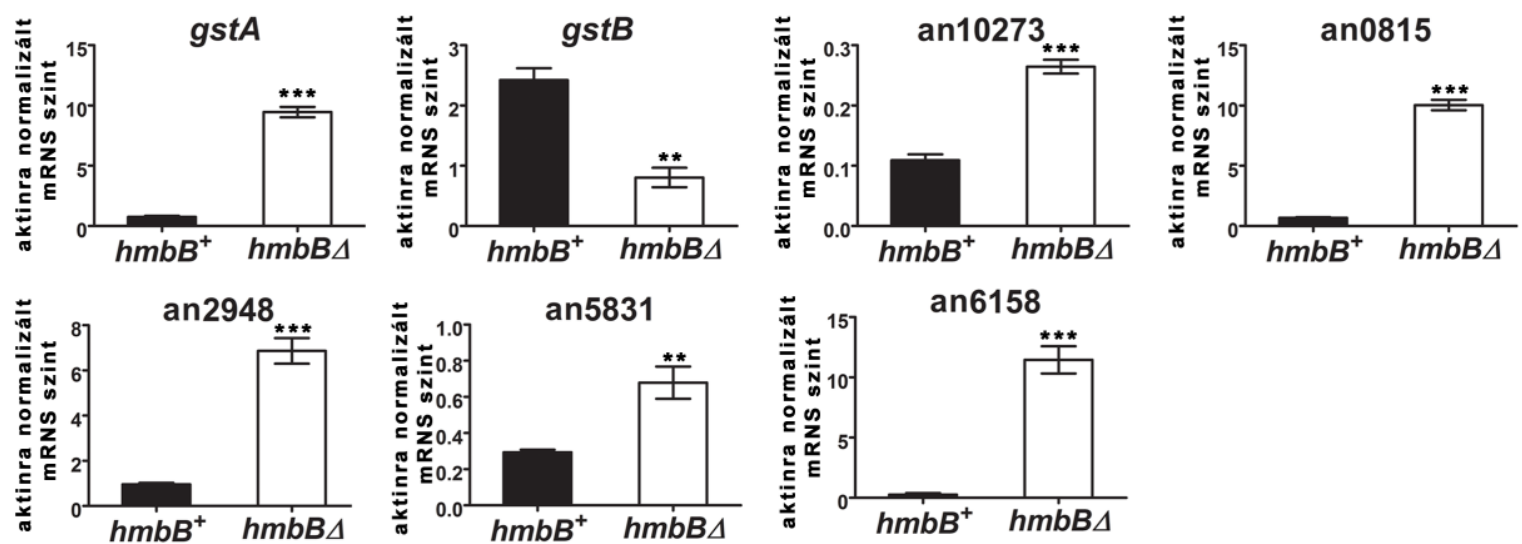

\section{glutation-oxidoreduktázok}
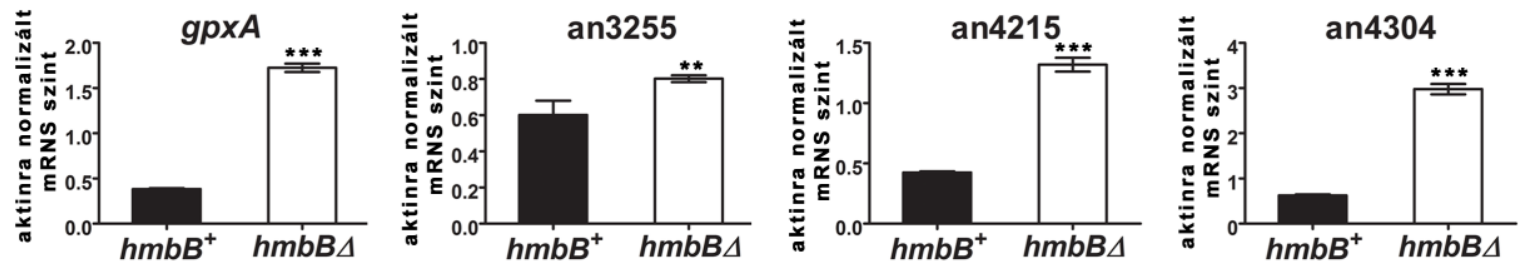

glutation-

reduktáz

tioredoxin-

reduktáz
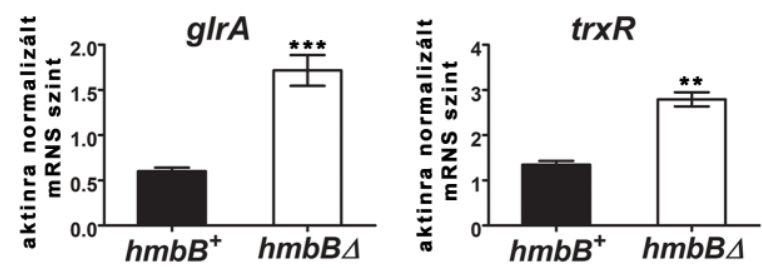

kataláz

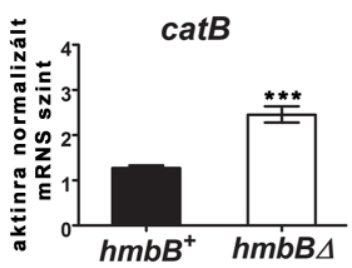

flavohemoprotein

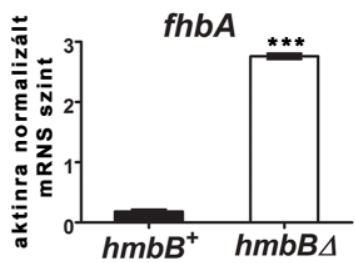

nitroreduktáz

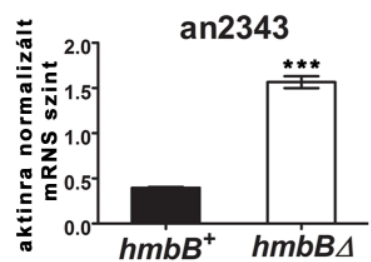

\section{szuperoxid-dizmutázok}

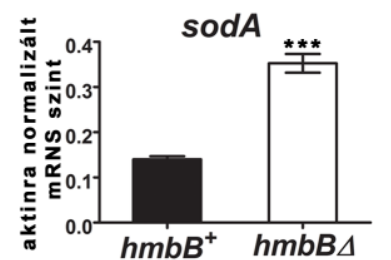

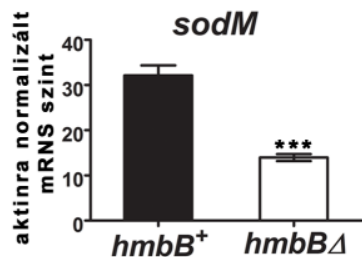

31. ábra: Glutation-S-transzferáz ( $g s t A$, gst $B$, an10273, an0815, an2948, an5831 és an6158), glutationoxidoreduktáz ( $g p x A$, an3255, an4215 és an4304), glutation-reduktáz ( $g l r A)$, tioredoxin-reduktáz ( $\operatorname{trx} R$ ), kataláz (catB), flavohemoprotein ( $f h b A)$, nitroreduktáz (an2343) és szuperoxid-dizmutáz ( $\operatorname{sod} A, \operatorname{sodB}$ és $\operatorname{sod} M)$ kódoló gének kifejeződése micéliumokban (22 óra) $h m b B^{+}$(HZS.118) és $h m b B \Delta$ (HZS.212) törzsekben. A 
diagramokon 3 mérésből számított szórásokat tüntettünk fel. A szignifikanciákat csillagok jelölik (** p <0,005; $* * * \mathrm{p}<, 0005)$

A glutation-S-transzferázok az oxidatív stressztől védelmet nyújtó rendszer fontos elemei. Ezt a funkciójukat elsősorban úgy valósítják meg, hogy a redox-aktív fehérjék szulfhidril oldalláncaihoz glutationt konjugálnak. Néhány GST azonban képes a GSH-t GSSG-vé oxidálni, így glutation-peroxidáz és diszulfid-reduktáz funkciót ellátni (glutaredoxinok). Megvizsgáltuk a GST-t kódoló gstA (Fraser és mtsai. 2002) és gstB (Sato és mtsai. 2009), öt feltételezett GST-t kódoló gén (AN10273, AN0815, AN2948, AN5831 és AN6158), valamint négy feltételezett glutaredoxint kódoló gén (gpxA, AN3255, AN4215 és AN4304) relatív mRNS-szintjét. A gstA, gpxA, AN3255, AN4304, GstB és AN10273 gének korábbi tanulmányok (Fraser és mtsai. 2002, Pócsi és mtsai. 2005, Pusztahelyi és mtsai. 2011) szerint stressz-indukáltak, ezért választottuk ki őket a vizsgálatainkhoz. A fennmaradó GST és glutaredoxin gének (AN0815, AN2948, AN5831, AN6158 és AN4215) szerepe még tisztázatlan, véletlenszerüen választottuk ki őket az AspGD adatbázisból (Arnaud és mtsai. 2012). Amint az a 31. ábrán látható, a gstA és AN1023 gének relatív mRNS-szintjei 12,8 és 2,7-szer magasabbak a $h m b B \Delta$ micéliumban a $h m b B^{+}$törzshöz képest, míg a gstB relatív kifejeződése 2,9-szer alacsonyabb volt. A feltételezett GST-t kódoló AN0815, AN2948, AN5831 és AN6158 gének kifejeződése nagymértékben megnövekedett a $h m b B \Delta$ micéliumokban (17,5; 7,5; 2,4 és 51,1-szeres növekedés). A feltételezett glutaredoxinokat kódoló gpxA, AN3235, AN4215 és AN4304 gének relatív mRNS-szintjei 4,6; 1,3; 3,5 és 5,1-szer magasabbak voltak a $h m b B \Delta$ micéliumokban a $h m b B^{+}$törzshöz viszonyítva.

A GrlA egy glutation-reduktáz, mely a GSSG-t redukálja GSH-vá, így kulcsszerepe van a sejt legfontosabb redox-párjának, a glutation redox-párnak müködésében (Sato és mtsai. 2009). A glrA hiányában a $\operatorname{trx} R$ (tioredoxin-reduktáz, $\operatorname{tr} A$-ként is ismert), catB (kataláz) és gstB gének kifejeződése fokozódik, kiegyenlítve a GlrA hiányából származó oxidált redox állapotot (Sato és mtsai. 2009). A glutation redox-pár és az egyéb redox rendszerek összefüggő müködése miatt megvizsgáltuk glrA kifejeződése mellett a trxR és catB gének kifejeződését is. Azt találtuk, hogy a glrA kifejeződése 2,8-szeresen magasabb volt a $h m b B \triangle$ micéliumokban, valamint a $\operatorname{trxR}$ és $c a t B$ gének kifejeződés is fokozódott $(2,1$ és 1,8-szeresen). A TrxR és GstB fehérjékről megállapították, hogy a FhbA (flavohemoprotein) és AN2343 (feltételezett nitroreduktáz) mellett részt vesznek a 0,8 mM menadion indukálta stresszre adott válaszban (Pusztahelyi és mtsai. 2011). Megvizsgáltuk az utóbbi két gén ( $f h b A$ és az AN2343) mRNS-szintjét is, ami a $h m b B \Delta$ micéliumokban 15,7 és 4,3-szeres túlmüködést mutatott a $h m b B^{+}$törzshöz viszonyítva. 
Mivel a $h m b B \Delta$ micéliumokban a szuperoxid-tartalom és a SOD enzimaktivitás kétszer magasabb volt a $h m b B^{+}$törzshöz viszonyítva, megvizsgáltuk a $\operatorname{sod} A, \operatorname{sod} B$, és $\operatorname{sod} M$ gének kifejeződését. Amint az a 31. ábrán látható, a $\operatorname{sodA}$ és $\operatorname{sodB}$ mRNS-ek szintje 2,6 és 1,8-szeresen magasabb volt a $h m b B \Delta$ micéliumokban, míg a sodM 2,3-szeresével csökkent. Az eredmények megvitatása a 6.5. fejezetben történik.

\subsection{A $h m b B \Delta$ törzs oxigénfelvétele a vad típushoz hasonló értéket mutat}

A $h m b B^{+}$és $h m b B \Delta$ törzsek redox állapotában megmutatkozó különbségek egyik oka lehet a mitokondriumok hibás müködése a deléciós törzsben. Ezért megvizsgáltuk a duzzadó konídiumok (3 óra) és micéliumból (16 óra) előállított protoplasztok oxigénfelvevő képességét a $h m b B^{+}$(HZS.118), hmbBA (HZS.212) és hmbB-his-tag (HZS.352) törzsek esetében (32. ábra). Meglepő módon a vad típushoz hasonló oxigénfelvételt mértünk a deléciós törzsben is (Karácsony és mtsai. 2015). A fejezet részletes tárgyalása a 6.5 . fejezetben történik.
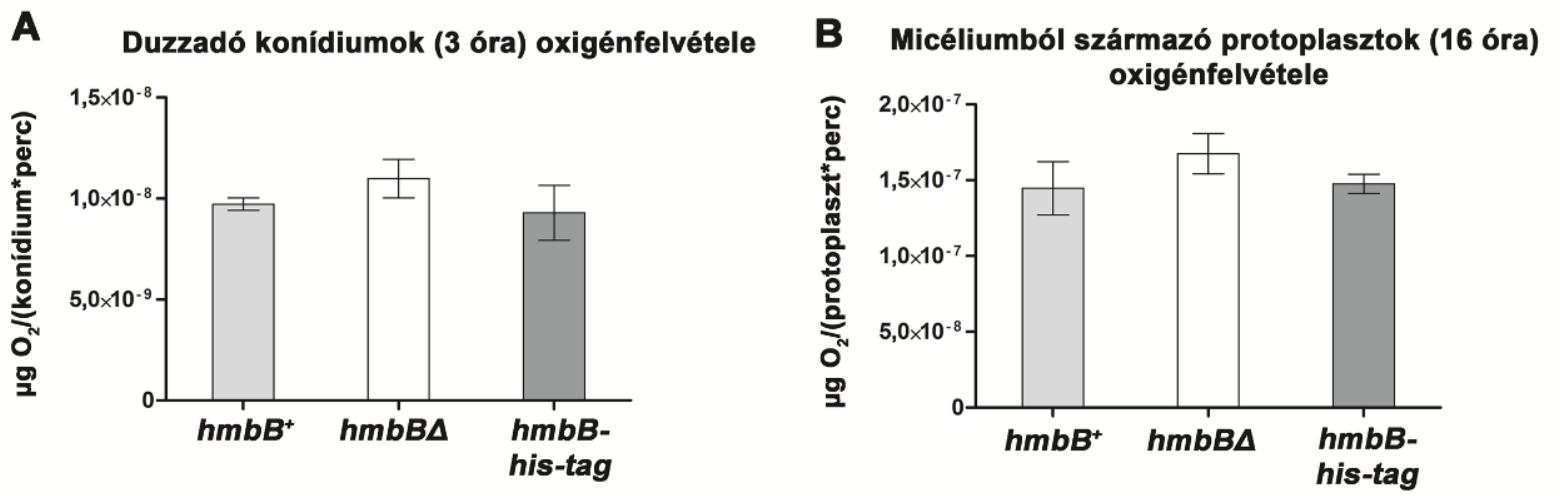

32. ábra: Duzzadó konídiumok ( 3 óra) és micéliumokból (16 óra) elöállított protoplasztok oxigénfelvétele. A: A $h m b B^{+}$(HZS.118), hmbB (HZS.212) és komplementációs kontroll hmbB-his-tag (HZS.352) törzsek duzzadó konídiumainak (3 óra) oxigénfelvétele. B: A $h m b B^{+}$(HZS.118), hmbBA (HZS.212) és komplementációs kontroll hmbB-his-tag (HZS.352) törzsek micéliumából (16 óra) előállított protoplasztok oxigénfelvétele. A feltüntetett szórásokat 3 mérésből számítottuk.

\subsection{A HmbC vizsgálata}

\subsubsection{A hmbCA deléciós törzs létrehozása}

A $h m b C$ gén deletálására létrehozott szubsztitúciós kazettát a Double Joint PCR módszerrel állítottuk elö (4.9. fejezet). Szelekciós markerként a pabaA ${ }^{+}$gént használtuk. A konstrukciókészítéshez felhasznált indítószekvenciákat az III. táblázat tartalmazza. A deléció létrehozásához egy pabaAl auxotróf A. nidulans törzset használtunk (HZS.314). A para-amino-benzoesavra nézve prototróf transzformánsok közül 30 törzset izoláltunk további vizsgálatokra. A $h m b C$ szekvencia detektálására tervezett PCR-alapú előszelekciót 
(hmbC frw és hmbC rev indítószekvenciák) követően, Southern-hibridizáció segítségével választottunk ki egy olyan törzset (HZS.338), mely esetében a deléciós kazetta egy kópiában integrálódott a genomba, a $h m b C$ lókuszban. A Southern-hibridizációs stratégiát a 33. ábrán mutatjuk be.

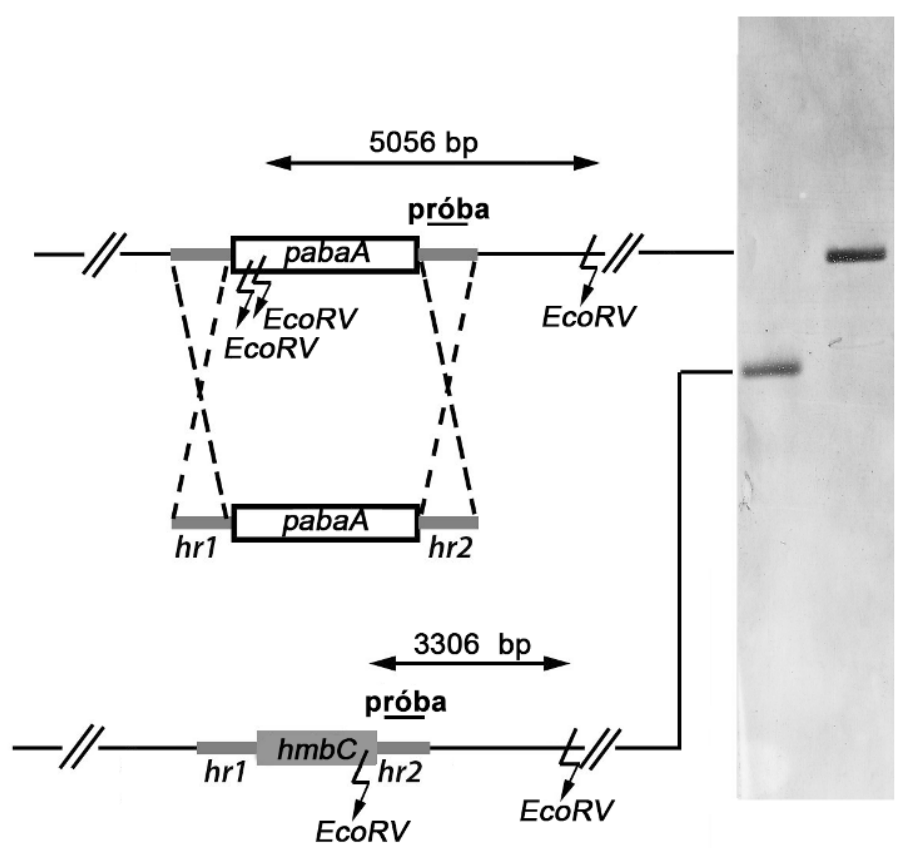

33. ábra: A $h m b C \Delta$ törzsek Southern-blot vizsgálata. A Double Joint PCR eljárással létrehozott, $p a b a A^{+}$ szekvenciát tartalmazó szubsztitúciós kazetta sémája az ábra közepén látható. A rövid szürke szegmensek a targetálást szolgáló, a genomi régióval homológ szakaszokat jelölik (hr1: a deletálás helyétől upstream irányba eső szekvencia, hr2: a deletálás helyétől downstream irányba eső szekvencia). A $h m b C^{+}$és a potenciális deléciós mutánsok DNS-ét EcoRV enzimmel emésztettük. A cikk-cakkos vonalak az EcoRV hasítóhelyeket jelölik. Hibridizációs próbának PCR eljárással (hmbC down frw és hmbC down rev indítószekvenciák, lásd III. táblázat) felszaporított szekvenciát használtunk, melyet az ábrán „,próba” névvel jelöltünk. A kettős nyilak az EcoRV-emésztésből származó termékek méretét jelölik. A jobb oldalon egy Southern-hibridizációs membránt ábrázoltunk a $h m b C^{+}$(HZS.120, bal oldal) és $h m b C \Delta$ (HZS.338, jobb oldal) jelekkel. Az alsó séma az intakt $h m b B$ lókuszt, a felső a kazetta beépülése esetén létrejövő $p a b a A^{+}$szelekciós markerrel szubsztituált lókuszt ábrázolja. A szaggatott vonalak homológ rekombinációs eseményeket jelölnek.

\subsubsection{A hmbCA törzs jellemzése}

A $h m b A \Delta$ és $h m b B \Delta$ törzsek esetén alkalmazott rutin fenotípusvizsgálatokat a $h m b C \Delta$ törzs esetén is elvégeztük, azonban egyik vizsgálat esetében sem kaptunk eltérést a kontroll törzshöz (HZS.118) képest. A HmbC funkció vizsgálata további kísérletek végrehajtását igényli a jövőben. 


\section{6. ÉRTÉKELÉS}

\subsection{A HmbA élettani szerepe}

A $h m b A \triangle$ és $h m b A^{+}$törzsek összehasonlító vizsgálatával megkezdtük a HmbA fehérje élettani szerepének felderítését. A deléciós törzs esetében a növekedési ráta szignifikáns csökkenését tapasztaltuk szénforrásként glükózt, nitrogénforrásként nátriumnitrátot tartalmazó MM táptalajon. A növekedési rátában meglévő különbség nem változott több megvizsgált szén és nitrogénforrás alkalmazása esetén sem. A növekedési rátát ozmostabilizátor (1 M szorbitol) alkalmazása nagymértékben fokozta, így valószínüsíthető a sérült sejtfalszintézis szerepe fenotípus kialakításában (Borgia és Dodge 1992).

A különböző stresszfaktorokkal szembeni tolerancia vizsgálata során megállapítottuk a hmbA4 törzs alacsony $\mathrm{pH}$ értékhez $(\mathrm{pH} 2,2)$ történő adaptációjának sérülését, mely abnormális morfológiában nyilvánult meg. Ez a fenotípus részlegesen komplementálható volt a tápközeg $0,7 \mathrm{M} \mathrm{KCl-al} \mathrm{történő} \mathrm{ozmotikus} \mathrm{stabilizálásával,} \mathrm{így} \mathrm{ennek} \mathrm{a} \mathrm{fenotípusnak}$ kialakításában is feltehetőleg szerepet játszik a sejtfalszintézis sérülése. A stresszkörülményekhez történő adaptáció során az A. nidulans sejtek a stresszágensek ellen védő metabolitokat (pl. trehalóz) halmoznak fel (Fillinger és mtsai. 2001). A trehalóztartalom és a $h m b A \Delta$ törzs savas pH-val szembeni érzékenysége közti esetleges kapcsolat felderítése érdekében összehasonlítottuk a $h m b A \Delta$ és $h m b A^{+}$törzsek micéliumainak és konídiumainak trehalóztartalmát. A várakozásoknak megfelelően mind a micéliumokban, mind a konídiumokban szignifikánsan alacsonyabb értéket mutattunk ki a deléciós törzs esetén.

Ismeretes, hogy a kromatin szerveződését befolyásoló faktorok kihatnak a másodlagos metabolit génklaszterek, így a mikotoxinok termelődéséért felelős génkalszterek kifejeződésére (Bok és Keller 2004), ezért összehasonlítottuk a $h m b A \Delta$ és $h m b A^{+}$törzsek sterigmatocisztin termelését. A vizsgálatok eredményei szerint a HmbA hiányában a gomba nem képes a sterigmatocisztint kimutatható mennyiségben termelni.

A jelen fejezetben bemutatott fenotípusok vizsgálatával a $\mathrm{HmbA}$ fehérje funkciójának jellemzése megkezdődött, további kísérletek szükségesek a fenotípusok molekuláris hátterének felderítésére és további fenotípusok azonosítására. 


\subsection{A HmbB szerkezete és lokalizációja}

A jelen dolgozatban jellemzett HmbB fehérje néhány új strukturális és funkcionális tulajdonságot mutat. A fehérjét kódoló gén majdnem a teljes Pezizomycotina altörzsben megtalálható és hiányzik a Saccharomycotina csoportból. Az ősi gén tehát, amelyből a nevezett fehérjék eredeztethetők, a Taphrinomycotina és a Pezizomycotina csoportok közös ősében megtalálható volt (Karácsony és mtsai. 2014). A fehérje hiánya a Saccharomycotina csoportban magyarázható a kódoló gén eltűnésével is. Ez ellentmondásnak tűnhet, mivel a Saccharomycotina és Pezizomycotina csoportokat testvér altörzseknek tartják a Taphrinomycotina-val, mely utóbbi az előző kettő bazális csoportjának tekinthető (Liu és Hall 2004, Liu és mtsai. 2009). Valójában, még ha a mitokondriális HMG-box fehérjék többször is függetlenül kialakulhattak a sejtmagi elödökböl, akkor is univerzális elterjedtséget mutatnának az Opistokonta csoportban (gombák, metazoák és rokon protisták). A $P$. polycephalum-ban jelen levő mitokondriális HMG fehérje létezése jól hangsúlyozza a HMG-box fehérjék mitokondriális szerepét az Unikonta csoportban (mely magában foglalja az Opistokontákat), bár egyes eukariótákban másképp fejlődött ki a mtDNS nukleoiddá szerveződése (pl. növények).

Ezidáig sem átfogó genomikai összehasonlításokat, sem pedig kísérletes munkát nem végeztek a mitokondriális DNS-hez (mtDNS) kapcsolt fehérjék azonosítására és eukariótákban történt evolválódásának tisztázására. Növényekben a mitokondriális- és kloroplaszt-DNS nem HMG-box fehérjékkel létesít kapcsolatot, hanem az MSH1-el (MutS homológ 1), amely a bakteriális MutS ,mismatch repair” fehérjével mutat hasonlóságot (Abdelnoor és mtsai. 2003, Xu és mtsai. 2011). A trypanoszómák közé tartozó Crithidia fasciculata és Trypanosoma cruzi fajokban H1 hiszton-szerü fehérjék kapcsolódnak a mitokondriális DNS-hez (Xu és mtsai. 1996, de Souza és mtsai. 2010), míg a Trypanosoma brucei mitokondriális nukleoid proteomikai vizsgálatok egy teljesen egyedi fehérjét azonosítottak, amely a trypanoszómák csoportján kívül sehol nem fordul elő (Beck és mtsai. 2013). Egy legújabb tanulmány szerint azonban létezik egy mitokondriális DNS-kapcsolt HMG-box fehérje is a T. brucei-ben, a TbKAP6, amely a mitokondriumban található és esszenciális a viabilitás szempontjából (Wang és mtsai. 2014). A folyamatról, amely során az evolúciós szempontból különböző eredetü fehérjék a mitokondriális nukleoiddal alakítottak ki kölcsönhatást, Kucej és Butow (2007) munkájában olvashatunk részletesen. 
A HmbB és a vele ortológ MtHmg1 nem azonosítható, de másodlagos szerkezet alapján struktúrális egységet mutató régiónak 3D modelljét összehasonlítva az emlős Tfam konzervatív HMG-box doménjével teljes szerkezeti azonosságot mutattunk ki. Ezzel fényt derítettünk arra, hogy a kanonikus C-teminális HMG-box-tól N-terminálisan álló hélixek két HMG-box szerü struktúrából állnak, melyeket ShHMG-box-nak (Shadow-HMG-box) neveztünk el (Karácsony és mtsai. 2014). Az emlős Tfam-ok két HMG-boxot hordoznak, melyek az őket elválasztó $\alpha$ hélix-szel és a HMG-boxoktól C-terminálisan található farokrésszel együtt jól tanulmányozottak mind a funkció-, mind pedig a szerkezet szempontjából (lásd irodalmi áttekintés). Ezekből a vizsgálatokból derült ki, hogy a két HMG-box domén biokémiai jellemzői és azok térbeli elrendeződésének eredményeképpen következik be a mitokondriális DNS U-alakban történő meghajlítása, amely lehetővé teszi, hogy a fehérje poláros C-terminális farokrésze kölcsönhatásba tudjon lépni a transzkripciós iniciációs régióban található fehérjékkel (Rubio-Cosialis és Sola 2013). Amikor a Tfam a humán LSP mitokondriális promóterhez kötődik, a C-terminális farokrész kölcsönhatásba lép a mitokondriális transzkripciós faktor B-vel, mely ennek hatására kapcsolatot létesít az mtRNS-polimerázzal (McCulloch és Shadel 2003). Az A. nidulans HmbB fehérjéje az emlős Tfam fehérjékhez hasonlóan - és ellentétben a $S$. cerevisiae Abf2p-vel, mely nem vesz részt a transzkripcióban rendelkezik egy hosszú poláros farokrégióval, amely a kanonikus HMG-boxtól C-terminálisan helyezkedik el (4. ábra). Ez alapján valószínünek tünik, hogy a HmbB képes részt venni a mitokondriális transzkripciós apparátus kialakításában a humán Tfam-hoz hasonlóan.

A HmbB mitokondriális jelenléte együtt jár az általunk kimutatott proteolitikus hasítással, ami a fehérje mitokondriális mátrixba történő importját kíséri. Ez a mitokondriális lokalizációt eredményező proteolízis az N-terminális végi ShHMG-boxot megcsonkítja, azonban tudjuk, hogy két HMG-box is elégséges a mtDNS hajlításához (Rubio-Cosialis és Sola 2013). Az MTS (Matrix Targeting Sequence) proteolízisét követően a HmbB fehérjén két komplett HMG-box, és két ismeretlen funkciójú N-terminális $\alpha$-hélix marad, mely utóbbin sejtmagi szignálszekvencia is található. A HmbB fehérje doménszerkezetét az 34. ábrán mutatjuk be. 


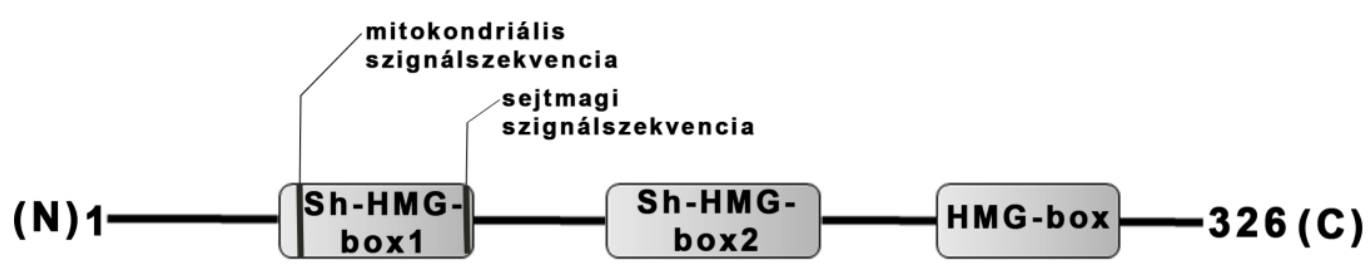

34. ábra: $A \mathrm{HmbB}$ fehérje doménszerkezetének sematikus, méretarányos ábrája. Az N-terminális irányból haladva a fehérjén két Shadow-HMG-box (Sh-HMG-box1 és Sh-HMG-box2), majd egy kanonikus HMG-box

(HMG-box) domén található. A Sh-HMG-box1 domén N-terminális régiójában mitokondriális szignálszekvencia, a C-terminális régiójában sejtmagi szignálszekvencia található. Az ábra szélein a számok a kezdő és utolsó aminosavak sorszámai.

Meglepő eredmény volt a HmbB sejtmagi jelenléte (Karácsony és mtsai. 2014). Amikor a humán Tfam fehérjét túltermelik, vagy deletálják az MTS-szekvenciáját, a fehérje a sejtmagban lokalizálódik (Pastukh és mtsai. 2008). Az egér Tfam fehérje alternatív splicing-al létrejövő variánsai közül az MTS-el nem rendelkező forma a spermatocita és spermatida sejtekben kizárólag a sejtmagban jelenik meg (Larsson és mtsai. 1996). A HmbB esetében mutatkozó kettős lokalizáció magyarázatára az MTS hasításán vagy nem hasításán (és nem az alternatív splicing-on) alapuló sejtmagi és mitokondriális izoformák létrejöttét feltételezzük. Rendkívül érdekes megfigyelésünk, amely a HmbB sejtmagi lokalizációjának a gombafonal egyes kompartmentjeire való korlátozódását mutatja, felveti a hifa különböző régióinak funkcionális specializáltságát, amelynek tisztázása további kutatásokat igényel.

\subsection{A HmbB szerepe a sterigmatocisztin bioszintézisében}

Kimutattuk, hogy a HmbB szükséges a sterigmatocisztin bioszintéziséhez, ami látszólag ellentmond a sterigmatocisztin bioszintéziséért felelős génklaszter vizsgált 3 génjét érintő transzkripciós vizsgálat eredményeivel (Karácsony és mtsai. 2014). Vonzó magyarázatként merül fel annak a lehetősége, hogy a sterigmatocisztin-bioszintézis génklaszter azokban a hifakompartmentekben íródik át, amelyekben a HmbB sejtmagi lokalizációt is mutat (5.3.4.8. fejezet). Ez egyben azt jelentené, hogy a másodlagos metabolitok képződése specializálódott hifakompartmentekre korlátozódik. Ez nem lenne meglepő eredmény, ugyanis a Fusarium graminearum-ban, ahol megtalálható a HmbB egyik ortológja, a trichotecén másodlagos metabolit bioszintéziséért felelős enzimek egy specifikus képletben, specializált ovoid sejtekben, a toxiszómákban lokalizálódnak (Menke és mtsai. 2013). A sterigmatocisztin és egyéb másodlagos metabolitok génklasztereinek aktivációjában és csendesítésében számos kromatin-kapcsolt protein vesz részt (Bok és mtsai. 2006, Reyes-Dominguez és mtsai. 2010, Soukup és mtsai. 2012, Nutzmann és mtsai. 
2013), ezért a HmbB konkrét szerepének meghatározása, és ezen szerep bemutatása a már ismert kromatinszabályozó faktorok viszonylatában rendkívül izgalmas új kutatási irányhoz vezet. Kísérleti eredményeink alapján nem zárhatjuk ki azt sem, hogy a HmbB szerepe a sterigmatocisztin bioszintézisében indirekt módon, a mitokondriumban betöltött funkciójából adódik. Ezt az elképzelést támogatja Shimizu és mtsai. (2012) eredménye, mely alapján a NAD+ és NADH mennyisége befolyással van a másodlagos metabolizmus génklaszterek kifejeződésére, feltehetőleg a H4 hiszton 16-os lizin aminosavának SirA mediált deacetilálásán keresztül. Saját kutatási eredményünk alapján talán még nagyobb mélységben tárulhat fel a sterigmatocisztin-bioszintézis regulációja, hiszen a deléciós mutánsban tapasztalt paradoxon a génklaszter gének transzkripciós aktivitása és a sterigmatocisztin bioszintézisének hiánya között, valamint a GFP-fúziós HmbB-t kifejező törzs esetében megfigyelt, vad típushoz hasonló mértékü sterigmatocisztin-termelődés a hmbBA törzshöz hasonló mértékü génkifejeződés mellett arra utal, hogy a HmbB fehérje a sterigmatocisztin bioszintézisére legalább két, egymástól független módon is képes hatni (Karácsony és mtsai. 2014).

\subsection{A HmbB szerepe az ivartalan és ivaros spórák csírázásában}

A $h m b B \Delta$ törzs esetében megfigyelt, a fehérje mitokondriális szerepével összefüggésbe hozható számos pleiotróp fenotípus (micéliális növekedés, morfológia, a konídiumok metabolizmusa, az oxidatív stresszel szembeni érzékenység) közül a legszembetűnőbb a HmbB fontossága a konídiospórák és aszkospórák csírázásában. A HmbB hiányában a konídiumok nagy részében drasztikusan lecsökken a mtDNS kópiaszáma, melynek mértéke teljes mértékben korrelál a konídiumok csírázóképességével (Karácsony és mtsai. 2014). Logikus azt feltételezni, hogy ok-okozati összefüggés van a mtDNS hiánya és a konídiumok alacsony csírázóképessége között. A hmbBA konídiumokból mindemellett nem hiányoznak a mitokondriumok, amelyekről MTT és MitoTracker RedFM festésekkel, valamint oxigénfogyasztásuk mérésével bizonyítottuk, hogy metabolikusan aktívak. Megállapítottuk, hogy a HmbB-fehérjék érett konídiumokban történő jelenléte a mitokondriumokban elengedhetetlen a mtDNS kópiaszámának fenntartásában (Karácsony és mtsai. 2014). A duzzadó konídiumokban fennálló mtDNSkópiaszám és az arról átíródó mRNS-ek mennyisége közötti aránytalanság (30. ábra) feltehetőleg a vizsgált mRNS-eknek a konídiogenezis során bekövetkező, a mtDNS szegregálódását megelőző transzkripciónak köszönhető és az mRNS-ek érett konídiumokban történő felhalmozódásának. A HmbB-GFP fehérje konídiofórokban történő eloszlása olyan 
események sorozatát veti fel, amelyek felelősek lehetnek a mtDNS elvesztésében a hmbBA törzs konídiogenezise során. Erös HmbB-GFP fluoreszcencia figyelhető meg a vezikulumban és a fialidokban, ahol a mitokondriumok erős felhalmozódását is megfigyeltük (26.A ábra, d és e panel). Ésszerü azt feltételezni, hogy a konídiumok fialidokról történő lefüződése során a mtDNS replikáción esik át a konídiumok mitokondriumaiban, amely folyamatban a HmbB-nek fontos szerepe van. Jelenleg nincs adat a szakirodalomban, ami bemutatná a mitokondriumok sorsát a konídiogenezis során az Aspergillus-okban, leszámítva néhány korai elektronmikroszkópos vizsgálatot, amely nem kifejezetten ezt a célt szolgálta, de mindenesetre igazolták a mitokondriumok vezikulumokban történő felhalmozódását (Weisberg és Turian 1971, Sewall és mtsai. 1990). Amiből kiindulhatunk, az az, hogy a konídiumok fialidokról történő lefüződésekor bekövetkező sejtmagosztódást párhuzamba lehet állítani a $S$. cerevisiae sarjadzásakor bekövetkező sejtmagosztódásával (Timberlake 1993), továbbá az, hogy a mitokondriális nukleoid szegregációjának vizsgálata során a $S$. cerevisiae abf2 deletált törzsében megfigyelték a mitokondriális nukleoidok összecsomagolódásának és aggregációjának sérülését, ami a mtDNS kópiaszámának csökkenését eredményezte a leánysejtekben (Miyakawa és mtsai. 2010). Igazoltuk, hogy a konídium csírázóképessége a hmbB $\triangle$ törzs esetében autonóm, nem komplementálható heterokarionokban (Karácsony és mtsai. 2014). Ez nem meglepő, mivel a sporuláló heterokarionok vezikulumai szinte kivétel nélkül homokariotikusak, amiből szükségszerüen következik, hogy a metulák és fialidok is azok, melyek közül az utóbbi már csak egy sejtmaggal rendelkezik (Timberlake 1990). Eredményeink mindenféleképpen arra utalnak, hogy a mtDNS szegregálódik a konídiogenezis során, de nem adnak választ arra a kérdésre, hogy a konídiogenezis melyik lépésében következik be ez a folyamat.

A HmbB fehérjének az aszkospórák csírázóképességében betöltött szerepe analóg a konídiumok esetében megfigyelttel. Azonban a konídiospórák csírázóképességével ellentétben sem a HmbB-GFP sem a GFP-HmbB fúziós konstrukció nem volt képes komplementálni az aszkospórák alacsony csírázóképességét (26. D ábra), amivel egybehangózan azt tapasztaltuk, hogy a fúziós fehérjék az aszkuszoknak és aszkospóráknak csak kis százalékába jutnak be (29. ábra). Úgy tünik, hogy a fúziós HmbB fehérje képtelen bejutni az aszkospórák mitokondriumaiba. Ez az eredmény bármilyen zavaró is első ránézésre, rámutat arra, hogy a mitokondriumok szegregációja az ivaros és ivartalan ciklus során eltérő módon valósulhat meg. 


\subsection{A HmbB fehérje hatása a redox környezetre}

Míg az összes glutation mennyisége nem különbözött a $h m b B^{+}$és $h m b B \Delta$ törzsek konídiumaiban, a GSSG mennyisége 20-szor kevesebb volt a deléciós törzsben. Ez az alacsony ROS- és SOD-mennyiségekkel együtt azt sugallja, hogy a $h m b B \Delta$ konídiumok reduktív redox állapotban vannak (5.3.4.10.1. fejezet). Feltételezzük, hogy ez az erősen reduktív belső környezet - akár kizárólagos - szerepet játszhat a deléciós törzs ivaros és ivartalan spóráinak rendkívül alacsony csírázóképességében. A $h m b B^{+}$és $h m b B \Delta$ törzsek micéliumának 5.3.4.10.1. fejezetben részletezett intracelluláris redox jellemzőinek főbb vonását a 35. ábrán foglaljuk össze.
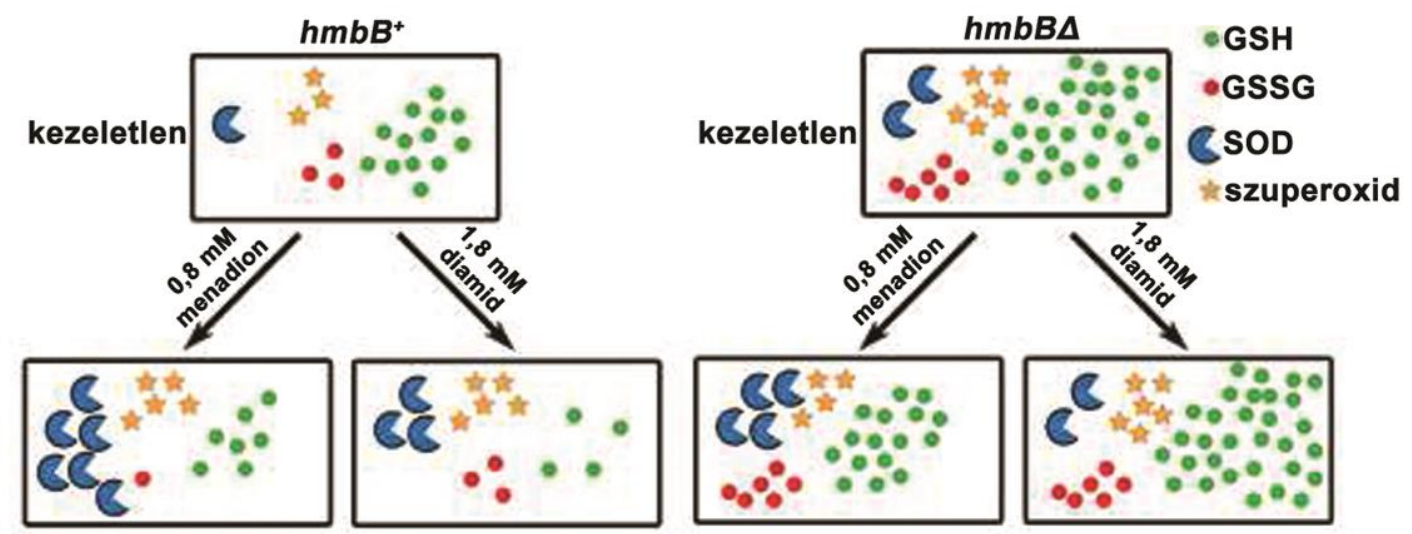

35. ábra: A GSH-, GSSG- és szuperoxid-tartalom, valamint a SOD aktivitás sematikus szemléltetése kezeletlen és menadionnal, vagy diamiddal kezelt $h m b B^{+}$(HZS.118) és $h m b B \Delta$ (HZS.212) törzsek micéliumaiban. Az ábra az VI. táblázat adatait szemlélteti. A kezeletlen micéliumokat 36 óráig neveltük $\mathrm{MM}+$ paba tápoldatban. Menadion- és diamidkezeléshez a törzseket 30 óráig MM+paba tápoldatban neveltük, majd a tápoldatokat $0,8 \mathrm{mM}$ menadionnal, vagy 1,8 $\mathrm{mM}$ diamiddal kiegészítve további 6 óráig inkubáltuk a tenyészeteket. GSH: redukált glutation, GSSG: oxidált glutation, SOD: szuperoxid dizmutáz.

A $h m b B \Delta$ micéliumok magasabb GSSG-tartalma arra utal, hogy a glutation redoxpár az oxidált állapot felé mozdul el, melyet csak kis mértékben tud kompenzálni a kimért GSH-szint növekedés, ami a redox-pár redukáló kapacitását próbálta növelni. A glutation redox-rendszer oxidált állapotából, valamint a megduplázódott szuperoxid- és SODmennyiségekböl arra következtetünk, hogy a $h m b B \Delta$ micéliumok endogén oxidatív stressznek vannak kitéve (35. ábra). Feltételezésünk szerint a $h m b B \Delta$ törzs paradox viselkedése, a menadionnal szemben mutatott fokozott érzékenysége és a diamiddal szemben mutatott toleráns fenotípusa a glutation redox-rendszerben bekövetkező változással és az endogén oxidatív stresszel magyarázható.

A menadionnal történő kezelés során a $h m b B \Delta$ micéliumok összes glutationtartalma a felére csökkent a $h m b B^{+}$törzshöz hasonlóan, a GSSG-tartalom azonban meglepő módon 
változatlan maradt a mutáns törzsben (35. ábra). Fontos, hogy a $h m b B^{+}$micéliumokban a kezelés hatására a GSSG-tartalom 4,2-szeresével csökken, ami egy olyan kompenzációs folyamat eredménye, amelynek szerepe a glutation redox-pár redox potenciáljának fenntartására irányul (35. ábra). Ez a kompenzációs folyamat a $h m b B \Delta$ micéliumokban nem müködik sikeresen (35. ábra) és ebből kifolyólag a glutation redox-pár egy oxidáltabb redox állapotba sodródik. Azt, hogy a $h m b B \Delta$ micéliumok menadion hatására fokozottabb oxidatív stressznek vannak kitéve, további kísérleti eredmények is igazolták. A G6PD aktivitása 1,6szorosával csökkent, ezzel szemben a glutation redox rendszer fenntartásáért felelős enzimek egy része hiperaktiválódott (8,5-szörös növekedés a GR és GST; 5,3-szoros növekedés a GPx aktivitásban). Mivel a G6PD felelős a NADP NADPH-vá történő redukálásáért (mely utóbbi a glutation redox rendszer termodinamikai hajtóereje), ezért a G6PD mennyisége limitáló tényezőként jelentkezik a deléciós micéliumokban. A G6PDaktivitás csökkenése a $h m b B \Delta$ micéliumokban a glutation redox kör kapacitásának csökkenéséhez vezet, ezért a mutáns törzs nem képes az intracelluláris redukáló erőt pótolni.

A diamid biológiai hatását elsősorban a redukált glutationtartalékok kimerítésén keresztül fejti ki, megváltoztatva a glutation redox-pár redox kapacitását (lásd $h m b B^{+}, 35$. ábra). A hmbB $\triangle$ micéliumok diamiddal szemben mutatott rezisztenciájának valószínü oka a GSH-tartalomban kereshető, amely a mutáns törzsben az alapállapothoz képest nem változik, a vad típusban azonban lényegesen lecsökken a diamiddal történő kezelés hatására (35. ábra). Azt gondoljuk, hogy ennek oka az, hogy a kezeletlen hmbBA micéliumokban a magas GSSG-szint által előidézett kompenzációs folyamat eredményeként megemelkedik a GSH-termelés, amely közvetlenül azt eredményezi, hogy diamidkezelés hatására a mutáns törzs rezisztens módon viselkedik.

A $h m b B^{+}$és $h m b B \Delta$ micéliumok és duzzadó konídiumok NADPH és NADP tartalmának összehasonlítása a glutationkörforgás tekintetében rávilágított arra, hogy a $h m b B^{+}$és $h m b B \Delta$ micéliumok és duzzadó konídiumok NADPH-tartalma ellentmondó eredményeket adott a minták NADP-tartalmának és G6PD-aktivitásának tükrében. A hmbBA konídiumokban a NADPH mennyisége a $h m b B^{+}$törzzsel megegyezó értéket mutatott, azonban a NADP mennyisége 7,9-szer magasabb, a G6PD aktivitása pedig 4,4-szeresével alacsonyabb volt a $h m b B^{+}$konídiumokhoz képest (36. ábra). 


\section{$\mathrm{A}: h m b B \Delta$ konídiumok}
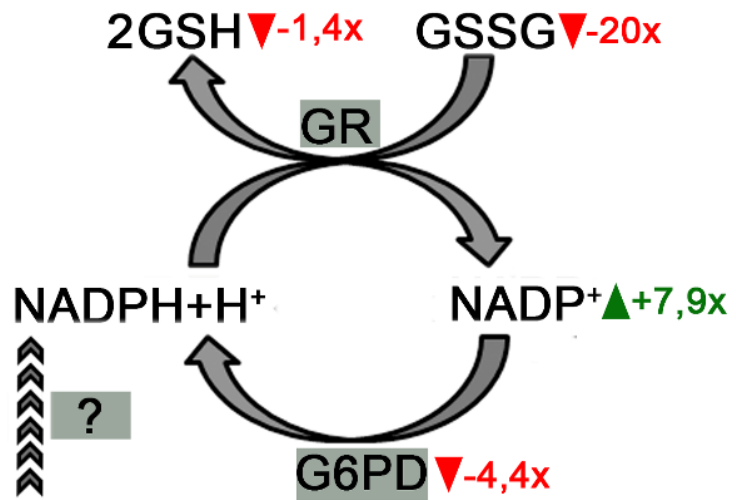

B:hmbB $\Delta$ micéliumok

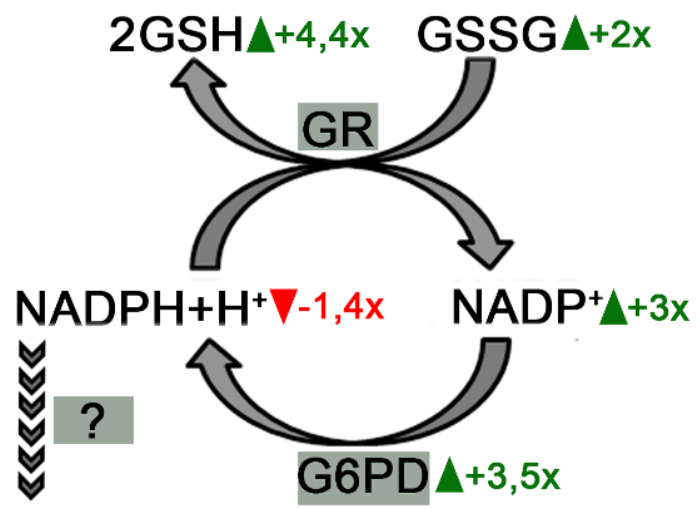

36. ábra: A GSH regenerációs ciklusában résztvevő GSH-, GSSG-, NADPH- és NADP-értékek, valamint a GR- és G6PD-aktivitások változásának bemutatása a $h m b B \Delta$ (HZS.212) duzzadó konídiumokban (A, 3 óra inkubálás) és a micéliumokban (B, 36 óra inkubálás) a $h m b B^{+}$(HZS.118) kontroll törzs estében mért értékekhez viszonyítva. Az értékeket az VI. táblázatban feltüntetett adatokból számoltuk. GSH: redukált glutation, GSSG: oxidált glutation, NADP: oxidált nikotinamid-adenin-dinukleotid-foszfát, $\mathrm{NADPH}+\mathrm{H}^{+}$: redukált nikotinamid-adenin-dinukleotid-foszfát, GR: glutation-reduktáz, G6PD: glükóz-6-foszfát dehidrogenáz. A kérdőjelet tartalmazó szürke dobozok nem felderített folyamatokat jelölnek. A felfelé irányuló nyilak a NADPH-betáplálást, a lefelé irányuló nyilak a NADPH-szivárgást mutatják.

A NADPH mennyisége jól korrelált a GSSG- és GSH-tartalommal, valamint a GRaktivitással, ami alátámasztja azt a következtetésünket, hogy a konídiumok reduktív belső környezettel rendelkeznek. Azonban a vad típuséhoz hasonló NADPH-mennyiség van jelen a hmbBA duzzadó konídiumaiban, annak ellenére, hogy a G6PD-aktivitás lényegesen alacsonyabb (36. ábra). A glutation-körforgásba történő váratlan NADPH-betáplálás legkézenfekvőbb magyarázata vagy a pentózfoszfát útvonalon kívüli egyéb NADPH-termelő metabolikus folyamatok túlműködése (pl.: malát útvonal, izocitrát útvonal, glutamát útvonal, vagy a nemrég jellemzett 10-formil-tetrahidrofolát útvonal (Fan és mtsai. 2014), vagy a NADP mitokondriumhoz kötött redukciójának fokozódása, amelyben a mitokondriális NADH és a transzhidrogenázok vesznek részt. Ezzel éppen ellentétes jelenséget figyeltünk meg a $h m b B \Delta$ micéliumokban. Itt annak ellenére, hogy a $h m b B^{+}$micéliumokhoz képest a NADP-szint 3,2-szeresen megemelkedett, a G6PD pedig 3,5-szeresen megemelkedett aktivitást mutatott, a NADPH mennyisége 1,4-szeresével lecsökkent (36. ábra). A NADPH mennyiségének váratlan csökkenése, a glutation-körforgásból történő elszivárgása hozzájárul a hmbBA micéliumok oxidatív redox állapotának létrehozásához, a GSSG felhalmozódásához és GSH mennyiségének elégtelenségéhez. A NADPH elszivárgását okozhatja a NADPH-t igénylö metabolikus folyamatok túlmüködése és/vagy a mitokondriális P450 rendszer aktivitásának fokozódása, mely utóbbi az oxigénmolekulákat egy elektronnal redukálva ártalmas szuperoxid gyökök képződését eredményezi. Ez utóbbi 
támasztja alá a $h m b B \Delta$ micéliumok magasabb szuperoxidtartalma (35. ábra), mely a vad típushoz hasonló oxigénfelvétel miatt (5.3.4.10.4. fejezet) nem származhat a légzési láncból. Ezeknek a megfigyeléseknek alapján valószínúleg a mitokondriális P450 rendszer fokozott müködése felelős a $h m b B \Delta$ micéliumok magas szuperoxid- és alacsony NADPH-tartalmáért.

A korábbi transzkriptomikai és proteomikai vizsgálatok során azonosított, a menadionkezelés hatására kifejeződő gének (Pócsi és mtsai. 2005, Pusztahelyi és mtsai. 2011) hmbBA micéliumokban történő átíródása jelentősen megváltozott (5.3.4.10.3. fejezet). Az összes GST-aktivitás megkétszereződött a $h m b B \Delta$ micéliumokban és a vizsgált feltételezett vagy azonosított GST-t kódoló gén kifejeződése is fokozódott a gstB kivételével. Erre a kivételre magyarázatot adhat a grlA megemelkedett átíródása. Sato és mtsai. (2009) megfigyelték, hogy a gstB magasabb szinten fejeződik ki grlAA genetikai hátterü törzsekben. A $h m b B \Delta$ törzsben a grlA 2,8-szor magasabb, a gstB viszont 2,9szeresével alacsonyabb szinten fejeződik ki, mint a $h m b B^{+}$törzs esetében, ami összhangban lehet a grlA expressziójának várt csökkenésével a gstB fokozott átíródása esetén.

Az általunk tanulmányozott összes ismert vagy feltételezett glutaredoxint kódoló gén magasabb szinten íródott át a $h m b B \Delta$ törzsben. Mivel a glutaredoxinok GSH-függő diszulfid-redukálók, kézenfekvő azt feltételezni, hogy ok-okozati összefüggés van a hmbBA micéliumban a glutaredoxinok fokozott átíródása és magas a GSSG-tartalom között. Emellett a glutaredoxinokat kódoló gének túlmüködése jelezheti azt is, hogy a $h m b B \Delta$ micéliumban fennálló intracelluláris oxidatív stressz kihat a redox-érzékeny (szulfhidril csoporttal rendelkező) fehérjékre.

Érdekes módon az AspGD genomi adatbázisból (Arnaud és mtsai. 2012) véletlenszerűen kiválasztott, feltételezett GST-t vagy glutaredoxinokat kódoló gének (AN0815, AN2948, AN5831, AN6158 és AN 4215) szignifikáns túlmüködést mutattak a hmbBA micéliumokban. Ezek az eredmények azt sugallják, hogy ezek a feltételezett GSTvagy glutaredoxin-aktivitással bíró géntermékek részt vesznek a glutationrendszer működésében és az oxidatív stresszel szembeni védelemben, így további kutatások célpontjai lehetnek, melyek hozzájárulnának a biológiai redox folyamatok mélyebb megismeréséhez.

Az összes GR-aktivitás nem különbözött a $h m b B^{+}$és $h m b B \Delta$ micéliumokban, azonban a $g l r A$ mRNS-ek 2,8-szeres mennyiségét mutattuk ki a mutáns törzsben a vad típushoz képest. Ennek oka lehet az enzim kifejeződésének transzláció szintjén történő 
szabályozása, vagy egyéb ok, pl. az enzim müködését befolyásoló körülmények (pl.: poszttranszlációs módosítás) hatása.

Az összes SOD-aktivitás megduplázódott a $h m b B \Delta$ micéliumokban. A SOD enzimet kódoló gének közül ( $\operatorname{sod} A$, $\operatorname{sodB}$, $\operatorname{sod} M)$ egyedül a $\operatorname{sod} A$ kifejeződésének mértéke nőtt meg lényegesen, 2,6-szeresére. Ennek alapján feltételezhetjük, hogy a SodA enzim egy domináns válaszfehérje a $h m b B \Delta$ törzs esetében kimutatott endogén oxidatív stressz során.

Mivel a légzést az ártalmas ROS-ok folyamatos termelődése kíséri, feltételeztük, hogy a $h m b B^{+}$és $h m b B \Delta$ micéliumok szuperoxid-tartalmának különbözősége (VI. táblázat) a légzési aktivitás megváltozására vezethető vissza. Nem várt eredményként közel megegyező oxigénfelvételi rátát mértünk a mutáns és vad típusok esetében a micéliumokban és a konídiumokban is. Annak tükrében, hogy Bakkaiova és mtsai. (2014), akik a Yarrowia lipolytica mitokondriális nukleoidot organizáló HMGB fehérjéjét vizsgálták (Ylmhb1p), a ylmhb1 géndeléciós törzsben vad típusú légzést mértek ki annak ellenére, hogy a deléciós mutánsban a hmbB $\Delta$ deléciós mutánshoz hasonlóan mtDNS kópiaszám-csökkenést és az arról átíródó mRNS-ek mennyiségének csökkenését tapasztalták, a saját légzési eredményeink alátámasztottnak tekinthetőek. Feltételezzük, hogy a HmbB fehérje nincs befolyással a légzés aktivitására, vagy ha igen, akkor a fehérje szerepének hiánya kompenzálható más fehérjék aktivitása által. Azt, hogy a HmbB hiányában ennek ellenére növekszik a micéliumok szuperoxid tartalma, valamely a légzési lánchoz nem kötődő, szuperoxidot termelő folyamat, pl. a mitokondriális citokróm P450 rendszer fokozott müködése okozhatja.

\subsection{A HmbB funkcióinak összefoglalása}

Kísérleteink eredményei igazolták a $\mathrm{HmbB}$ fehérje szerepét számos élettani folyamatban. Mivel a $\mathrm{HmbB}$ fontos szerepet tölt be az ivartalan és ivaros spórák csírázóképességében, a mitokondriális DNS replikációjában, a sterigmatocisztin-termelésben és a sejt redox környezetének fenntartásában, rendkívül izgalmas távlatokat nyitna annak vizsgálata, hogy ezek a biológiai folyamatok direkt vagy indirekt módon kötődnek a HmbB fehérjéhez. Az oxidatív stressz, a másodlagos metabolizmus és a szexuális ciklus közötti érdekes összefüggésekre csak az utóbbi években kezdtek felfigyelni, amely során például fényt derítettek arra, hogy A. nidulans-ban a NapA és DlpA stresszválasz-fehérjék fontos szerepet töltenek be a fejlödési folyamatokban és a sterigmatocisztin-termelésben (Wartenberg és mtsai. 2012, Yin és mtsai. 2013) 
A HmbB fehérje részletes vizsgálatával, nem csak a HMG-box fehérjék szerepével kapcsolatos ismereteket sikerült bővítenünk, de eredményeink rávilágítottak néhány érdekes, eddig nem kutatott folyamat lehetőségére $A$. nidulans esetén.

A HmbB az ivartalan és ivaros spórák csírázásában betöltött szerepét valószínüleg a gomba redox állapotának befolyásolásával éri el (Karácsony és mtsai. 2015), rámutatva a redox állapot és a csírázóképesség összefüggésére.

A GFP-vel fúzionált $\mathrm{HmbB}$ fehérje a deléciós mutánsban kifejeztetve csak az ivartalan spórák mitokondriumaiban halmozódott fel és javította a csírázóképességet. Az ivaros spórák esetében ez nem valósult meg (Karácsony és mtsai. 2014). Az eredmény egyértelmüen arra utal, hogy a mitokondriumok spórákba kerülése az ivaros és ivartalan spórák esetében különböző mechanizmusok által valósul meg. A folyamatok felderítése további kutatások tárgyát képezheti.

A fehérje lokalizációjának vizsgálatával megállapítottuk annak kettős jellegét. A GFP-vel fúzionált $\mathrm{HmbB}$ a mitokondriumban minden esetben, a sejtmagban viszont csak alkalmanként, néhány sejtben fordult elő (Karácsony és mtsai. 2014). Ez az eredmény utalhat egy-egy sejt adaptációjára speciális funkciókhoz pl. mikotoxin termelés.

A sterigmatocisztin termelés és a szintézisgének átíródása közti ellentmondás azt sugallja, hogy a mikotoxin szintézise nem csak a transzkripció szintjén szabályozott, hanem a transzkripció után (transzláció/poszt-transzláció), vagy a bioszintézisben szerepet játszó faktorok szabályozásával valósul meg (Karácsony és mtsai. 2014).

Az endogén oxidatív stressz alatt álló $h m b B \Delta$ micéliumokban az általunk megvizsgált, a szekvenciájuk alapján feltételezhetően GST-t, vagy glutaredoxinokat kódoló gének átíródása megemelkedett (Karácsony és mtsai. 2015). Ez az eredemény alátámasztja az említett gének szerepét a normál redox állapot fenntartásában, így indokolt a gének által kódolt fehérjék oxidatív stressz elleni védelemben betöltött szerepének kutatása. 


\section{7. ÖSSZEFOGLALÁS}

Az Aspergillus nidulans az egyik legjobban tanulmányozott fonalasgomba modellszervezet. Számos biológiai folyamatot tanulmányoztak részletesen segítségével, pl. az életciklus szabályozását, transzportfolyamatokat, másodlagos metabolit-termelést és stresszfolyamatokat. Az utóbbi években intenzíven tanulmányozták az A. nidulans kromatinszerveződését és kromatinszerkezetét is. Ezek a kutatások azonban nem terjedtek ki az A. nidulans-ban található architektúrális High Mobility Group (HMG) fehérjékre, mely fehérjék azonosítása és jellemzése Saccharomyces cerevisiae és Candida albicans fajokban már régóta folyik. Ezért munkánk céljául tüztük ki az A. nidulans HMG fehérjék azonosítását és élettani szerepük jellemzését, különös tekintettel a mitokondriális HMG-box fehérjére.

In silico vizsgálattal az A. nidulans genomjában hét HMG-box domén fehérjét kódoló gént találtunk, melyek közül három, feltehetőleg architektúrális szerepet betöltő HMG-box fehérjét választottunk ki vizsgálatainkhoz (AN2885 azaz HmbA, AN1267 azaz HmbB és AN10103 azaz HmbC). Bioinformatikai vizsgálatokkal kimutattuk, hogy a HmbC fehérje két HMG-box domént hordoz, legközelebbi jellemzett homológjai a Hmol ( $S$. cerevisiae) és Sp-Hmo1 (S. pombe) fehérjék. A HmbA fehérje egyetlen HMG-box domént hordoz, ortológ az architektúrális szerepet betöltő Nhp6A/B (S. cerevisiae) fehérjékkel. A HmbB egyetlen konzervált HMG-box domént hordoz, amit rendkívül hosszú N-terminális régió előz meg. A hosszú N-terminális régióhoz semmilyen ismert PFAM domén nem volt köthető.

Az HmbB filogenetikai vizsgálatának eredményei, valamint a meglévő intronok pozícionálódásának abszolút konzerváltsága alapján megállapítottuk, hogy a teljes Pezizomycotina csoport, valamint a Taphrinomycotina csoporton belül a Pneumocystis fajok HmbB-vel ortológ fehérjét hordoznak. Ez arra utal, hogy az ösi gén, amelyből a mai ortológok eredeztethetők, a Taphrinomycotina és a Pezizomycotina csoportok közös ősében megtalálható volt.

Bioinformatikai elemzésünk alapján a HmbB és néhány ortológja valószínűleg tartalmaz egy mitokondriális pre-peptidet az N-terminálison. A HmbB tartalmaz sejtmagi transzportot eredményező motívumot is a szekvenciavizsgálat szerint. Háromdimenziós modellezéssel 3 HMG-box jelenlétét azonosítottuk a HmbB-ben, melyek mindegyike tökéletesen illeszthető volt a humán HMGB1 konzervált HMG-boxának háromdimenziós 
modelljére. Ez arra derített fényt, hogy bár a kódoló szekvencia rendkívüli mértékben divergál, a szerkezet szigorúan konzervatív marad. Mivel AS-homológia alapján nem lehet a HmbB két N-terminális HMG-boxát azonosítani, azonban szerkezetileg egyértelműen HMG-box domének, ezért ShHMG-box-nak (Shadow-HMG-box) neveztük el őket. A HmbB rendelkezik egy hosszú C-terminális poláros farokrégióval, ami a humán Tfam fehérjék analógiája alapján valószínűsíthetően kölcsönhatásba lép a mitokondriális transzkripciós apparátussal - ellentétben a vizsgált élesztő mitokondriális fehérjékkel.

Megvizsgálva a $h m b B$ transzkripciós szintjét, kimutattuk, hogy a $\mathrm{HmbB}$ fehérjét kódoló mRNS az A. nidulans fejlődése során folyamatosan és nagy mennyiségben van jelen, ami a fehérje fontosságára illetve szerepének általános szükségességére utal.

A HmbB-GFP és GFP-HmbB fúziós fehérjék lokalizációját $h m b B \Delta$ genetikai háttéren vizsgálva megállapítottuk, hogy a $\mathrm{HmbB}$ fehérje mitokondriális lokalizációt mutat nyugvó spórában, valamint az izotropikus növekedési és micéliális fázisban is. Ritkán, szeptumok által határolt kompartmentekben megfigyeltük a fúziós fehérjék kettős (mitokondriális és sejtmagi) lokalizációját is, amely Western-blot analízisünk alapján inkább a MLS motívum pre-peptid hasítása, vagy nem hasítása okán kialakuló HmbB izoformáknak köszönhető, semmint mRNS splicinggal létrejövő izoformáknak. A kompartment-specifikus nukleáris lokalizáció felveti annak a lehetőségét, hogy egyes hifakompartmentek specializálódtak valamilyen biológiai folyamatra (pl. sterigmatocisztin-bioszintézis), melyre a HmbB hatást gyakorol.

Kimutattuk, hogy HmbB hiányában a sterigmatocisztin-bioszintézis vagy drasztikusan lecsökkent vagy elmaradt, miközben a sterigmatocisztin-szintézisért felelős génklaszter 3 vizsgált génjének transzkripciója jelentősen fokozódott. Ezen kívül a GFP-vel fúzionáltatott $\mathrm{HmbB}$ fehérjét kifejező törzsek a vad típushoz hasonló mértékü sterigmatocisztin-termelést mutattak, de a bioszintézis génklaszter vizsgált génjei a $h m b B \Delta$ törzshöz hasonló szinten fejeződtek ki. Ez a látszólagos ellentmondás könnyen feloldható azzal, hogy a HmbB fehérje a sterigmatocisztin bioszintézisére legalább két, egymástól független módon is képes hatni. A szintézisgének transzkripciójának szabályozásán felül a HmbB például a megfelelő NADPH/NADP arány fenntartásával is befolyással lehet a sterigmatocisztin szintézisére.

Kimutattuk, hogy a HmbB esszenciális az ivartalan és ivaros spórák csírázásához. A fehérje hiányában az ivartalan spórák mtDNS-kópiaszáma drasztikusan lecsökken, melynek 
mennyisége korrelál a spórák csírázóképességével. Feltehetőleg összefüggés van az alacsony csírázóképesség és a lecsökkent mtDNS-tartalom között. Mindemellett a $h m b B \Delta$ konídiumok mitokondriumainak mikroszkópos vizsgálata és az oxigénfelvétel sebességének meghatározása alapján úgy tünik, hogy a $h m b B \Delta$ konídiumok a vad típussal megegyező számú, funkcionáló mitokondriummal rendelkeznek. A HmbB-GFP koncentrálódása a vezikulumokban és a fialidokban, valamint az ivartalan spórák lecsökkent mtDNS-tartalma arra utal, hogy a HmbB fehérjének fontos szerepe van az mtDNS konídiumokba történő szegregálódásában a konídiogenezis során. A HmbB fehérjének az aszkospórák csírázóképességében betöltött szerepe analóg lehet a konídiumok esetében megfigyelttel, azonban a konídiospórákkal szemben a GFP fúziós HmbB csak az aszkuszok és aszkospórák kis százalékába jutott be, ezért a GFP-fúziós fehérje az aszkospórák alacsony csírázóképességét nem komplementálta. Ez arra utal, hogy a mitokondriumok szegregációja az ivaros és ivartalan ciklus során eltérő módon valósul meg.

A $h m b B \Delta$ konídiumok redox rendszereinek vizsgálati eredményei (alacsony GSSG-, szuperoxid- és SOD-tartalom) arra utalnak, hogy a $h m b B \Delta$ izotropikus növekedésben lévő konídiumokat reduktív intracelluláris redox környezet jellemzi. Ez a jelenség összefügghet a $h m b B \Delta$ spórák alacsony csírázóképességével. A $h m b B \Delta$ konídiumokban a $h m b B^{+}$ konídiumokkal megegyezö NADPH-szint ellenére alacsonyabb G6PD-aktivitást észleltünk, mint ami a $h m b B^{+}$konídiumokban megfigyelhető. Ez arra utal, hogy a pentóz-foszfát útvonalon kívülről NADPH-betáplálás történik a legföbb redox-környezetet befolyásoló rendszerbe (GSH-GSSG rendszer), amely származhat egyéb NADPH-termelő metabolikus folyamatok túlmüködéséböl, vagy a NADP mitokondriumhoz-kötött redukciójának fokozódásából.

Megállapítottuk, hogy a $h m b B \Delta$ micélium endogén oxidatív stressznek van kitéve, ami összefügg azzal, hogy a glutation redox rendszerből NADPH-szivárgás történik. Ennek egyik lehetséges oka a mitokondriális P450 rendszer túlműködése, mely NADPHfelhasználás mellett szuperoxid gyököket termel. Ez összhangban áll a micéliumok magas szuperoxid-tartalmával.

Részletesen feltártuk a $h m b B \Delta$ mutáns menadionnal szemben mutatott fokozott érzékenységének, valamint a diamiddal szemben mutatott fokozott toleranciájának kialakításához hozzájáruló faktorokat. Vizsgálataink során azt találtuk, hogy menadionstressz alatt a $h m b B \Delta$ micéliumokban a $h m b B^{+}$törzshöz képest a glutation redox-pár 
oxidáltabb állapotba kerül, valamint csökken a $h m b B \Delta$ sejtek G6PD-aktivitása. A csökkent mennyiségü G6PD nem képes a glutation redox kör kapacitását fenntartó, megfelelö mennyiségü NADPH előállítására. A glutation-rendszer csökkent kapacitása és a sejtek endogén oxidatív stressznek való kitettsége lehet az oka a $h m b B \Delta$ törzs menadionnal szemben mutatott fokozott érzékenységének. Diamid oxidatív stresszágenssel történő kezelés hatására a $h m b B^{+}$törzsben a felére csökken a GSH-tartalom, míg a $h m b B \Delta$ törzsben az változatlan marad. Így a kezeletlen $h m b B \Delta$ micéliumokban a magas GSSG-szint által előidézett kompenzációs folyamat eredményeként megemelkedik a GSH-termelés, ami azt eredményezi, hogy a diamid - egy adott alkalmazott koncentrációig - a fennálló glutationrendszer müködésének károsítása nélkül redukálódik. A jelenség fenotipikusan a deléciós törzs diamid-toleranciájának növekedésében nyilvánul meg.

A HmbB élettani szerepének részletes vizsgálata mellett elkezdtük a HmbA és HmbC fehérjék szerepének vizsgálatát. A $h m b A \Delta$ törzs vizsgálatával kimutattuk a HmbA szerepét a növekedésben, a trehalóz- és sterigmatocisztin-bioszintézisben, valamint fontosságát az alacsony $\mathrm{pH}$-értékhez történő adaptációban. Az alacsony növekedési ráta és az alacsony $\mathrm{pH}$ értékhez történő adaptáció sérülése részlegesen komplementálható volt a tápközeg ozmostabilizálásával, így feltételezhető a HmbA szerepe a sejtfalszintézis szabályozásában. A fenotípusok molekuláris hátterének felderítése további kísérleteket igényel. A $h m b C \Delta$ törzs esetében elvégzett növekedési képesség- és stresszvizsgálatok eredményei nem mutattak eltérést a kontroll $h m b C^{+}$törzshöz viszonyítva. 


\section{SUMMARY}

Aspergillus nidulans is a well characterized model organism. Several biological processes have been studied in this species (such as regulation of life cycle, transport processes, secondary metabolite synthesis, signal transduction processes, stress responses etc.) Although the chromatin structure and chromatin organization of A. nidulans have been intensively studied in the last years, these researches haven't involved the architectural High Mobility Group (HMG) proteins of A. nidulans. In the Saccharomyces cerevisiae and Candida albicans model organisms, and even in higher metazoans as humans, the identification and characterization of the architectural HMG proteins is a widely studied area. Therefore we aimed to identify the HMG proteins in A. nidulans and characterize their physiological role.

Seven HMG-box protein coding genes were identified in the A. nidulans genome by BLAST search. Three putative architectural HMG-box proteins were chosen for our further work (AN2885 or HmbA, AN1267 or HmbB, AN10103 or HmbC). Bioinformatic studies showed that HmbC has two HMG-box domains and its closest orthologues are the Hmol ( $S$. cerevisiae) and Sp-Hmo1 (S. pombe) proteins. The HmbA protein contains one HMG-box domain. The putative orthologues of $\mathrm{HmbA}$ are the architectural Nhp6A/B proteins of $S$. cerevisiae. The HmbB contains one conserved HMG-box domain and a long N-terminal sequence. The long N-terminal region could not be recognized as any of the PFAM domains.

The phylogenetic investigation of $\mathrm{HmbB}$ and the conserved intron positions showed that the orthologues of $\mathrm{HmbB}$ are present in the whole Pezizomycotina group and in the Pneumocystis species of Taphrinomycotina. This suggests that the ascendant gene was present in the common ancestor of Taphrinomycotina and Pezizomycotina groups.

According to our bioinformatic investigations, all of the HmbB orthologues carry a mitochondrial pre-peptide on the N-termini. The HmbB contains a nuclear transport signal, too according to the sequence analysis. We identified two HMG-boxes at the N-terminal region that precedes the conserved C-terminal HMG-box in HmbB on terms of structural resemblance instead of amino acid homology. 3D models of these two N-terminal HMGboxes were superimposed to the conserved second HMG-box of the human HMGB1 protein and we got that they were perfectly aligned with the human HMG-box. This study revealed that while the amino acid sequence may diverge at such scale that forbids the identification at amino acid levels, the structure remains astonishingly conserved. Since the two N- 
terminal HMG-box domains of HmbB can't be identified by sequence homology, but clearly show the structure of a HMG-box, they were named as Sh-HMG-boxes (Shadow-HMGbox). Despite of the other studied fungal mitochondrial HMGB proteins, the HmbB contains a C-terminal polar region, which possibly interacts with the mitochondrial transcription complex like Tfam proteins of human and mice.

By measuring the transcriptional activity of $h m b B$ we found that the gene is expressed at a high level during all phases of the development of $A$. nidulans. This suggests that the HmbB protein has important and general functions.

The HmbB-GFP and GFP-HmbB fusion proteins were localized in the mitochondria in resting conidia, isotropic growth phase conidia and mycelia. Occasionally the GFP fusion proteins were localized both in mitochondria and nuclei in particular hyphal compartments enclosed by septa. According to our Western blot experiments, the dual localization is possibly the result of the $\mathrm{HmbB}$ isoforms formed by the cleavage of the $\mathrm{N}$-terminal MTS (Matrix Targeting Sequence) instead of alternative mRNA splicing. The fact that the nuclear localization of $\mathrm{HmbB}$ is limited to distinct hyphal compartments suggests that these compartments are specialized to some biological processes (e.g. sterigmatocystin synthesis) in which the HmbB may take part.

We showed that in the abscence of HmbB the sterigmatocystin biosynthesis was drastically decreased or absent, despite the transcription of three investigated genes of sterigmatocystin biosynthesis cluster were significantly increased. The strains which expressed the GFP-fused HmbB showed wild type-like sterigmatocystin synthesis but a $h m b B \Delta$-like transcription profile of the investigated biosynthesis genes at the same time. This phenomenon indicates that the HmbB has an effect on sterigmatocystin synthesis by at least two independent ways.

We showed that the $\mathrm{HmbB}$ is essential for the germination of sexual and asexual spores. In the absence of $\mathrm{HmbB}$ the mtDNA copy number drastically decreases which correlates with the germination ability of the spores. There is possibly a relationship between the decreased copy number of mtDNA and the low germination ability. The microscopic examinations and the respiration rate measurements suggest that the $h m b B \Delta$ conidia have the same number of functioning mitochondria as wild type. The accumulation of HmbB-GFP in the vesicle and phialides and the reduced mtDNA content of the conidia indicate that the $\mathrm{HmbB}$ has an important role in the segregation of mtDNA into conidia during 
conidiogenesis. The role of $\mathrm{HmbB}$ in the germination of ascospores may be analogous with that observed in the case of conidia. Contrary to the conidia, the GFP-fused HmbB proteins were accumulated in just a few percent of asci and ascospores, thus the GFP-fused protein could not complement the low germination ability of ascospores. This indicates that the segregation of mitochondria occurs by different processes during the sexual and asexual cycle.

Study of the redox systems revealed that the isotropic growth phase conidia of $h m b B \Delta$ have a reductive intracellular environment (characterized by low GSSG, superoxide and SOD content), which might be related to the reduced germination ability of the conidiospores. In the $h m b B \Delta$ conidia we measured the same level of NADPH as in $h m b B^{+}$ conidia but a lower G6PD activity at the same time. This together with the low GSSG level indicates a source of NADPH for the GSSG-GSH redox system other than the pentosephosphate pathway, such as other metabolic processes and/or the mitochondrial NADP reduction.

We revealed that the $h m b B \Delta$ mycelia are exposed to endogenous oxidative stress which may be in causal relation with the detected leakage of NADPH from the GSH/GSSG redox cycle. The possible cause of the NADPH leakage may be the increase of NADPH consuming metabolic processes or the increased activity of mitochondrial P450 system, which consume NADPH and produce superoxide. This latter corresponds well to the elevated superoxide content of $h m b B \Delta$ mycelia.

We revealed those factors which contribute to the increased menadione and the decreased diamide sensitivity of $h m b B \triangle$ mycelia. We found that during menadione treatment the glutathione redox pair was in a more oxidised state than in $h m b B^{+}$mycelia and the G6PD activity was decreased in $h m b B \Delta$ compared to $h m b B^{+}$mycelia. The decreased G6PD activity can not produce the necessary amount of NADPH to maintain the capacity of the glutathione redox cycle. The decreased capacity of the glutathione redox system and the endogenous oxidative stress may be the causes of the increased menadione sensitivity of $h m b B \Delta$ mycelia. During diamide treatment the GSH content was halved in $\mathrm{hmbB}^{+}$while it did not change in $h m b B \Delta$. The elevated level of GSSG in the untreated $h m b B \Delta$ mycelia induced a compensatory process leading to an increase in the GSH production, therefore the diamide can be reduced in the mutant (at a certain applied concentration) without the concomitant 
damage of the glutathione redox system. This leads to the increased tolerance of $h m b B \Delta$ against diamide.

We began the examination of the physiological roles of HmbA and HmbC proteins. We proved the important role of HmbA in mycelial growth, trehalose and sterigmatocystin synthesis, and in the adaptation to acidic $\mathrm{pH}$. The decreased growth and the abnormal adaptation to acid stress were partially complemented by the osmostabilization of the medium. This suggests that the HmbA may plays a role in the regulation of cell wall synthesis. Further experiments are needed in the future to unravel the molecular background of these phenotypes. The growth and stress tolerance experiments carried out on $h m b C \Delta$ did not reveal any phenotype. 


\section{IRODALOMJEGYZÉK}

Abdelnoor, R. V., R. Yule, A. Elo, A. C. Christensen, G. Meyer-Gauen, S. A. Mackenzie, (2003) Substoichiometric shifting in the plant mitochondrial genome is influenced by a gene homologous to MutS. Proc. Natl. Acad. Sci. USA 100: 5968-5973.

Adams, T. H., J.K. Wieser, J. H. Yu, (1998) Asexual sporulation in Aspergillus nidulans Microbiol. Mol. Biol. Rev. 62(1): 35-54.

Albert, B., C. Colleran, I. Leger-Silvestre, A. B. Berger, C. Dez, C. Normand, J. PerezFernandez, B. McStay, O. Gadal, (2013) Structure-function analysis of Hmo1 unveils an ancestral organization of HMG-Box factors involved in ribosomal DNA transcription from yeast to human. Nucl. Acids Res. 41: 10135-10149.

Anderson, M. E., (1995) Determination of glutathione and glutathione disulphide in biological samples. Methods Enzymol. 113: 548-555.

Anisimova, M., O. Gascuel, (2006) Approximate likelihood-ratio test for branches: A fast, accurate, and powerful alternative. Syst. Biol. 55: 539-552.

Antal, Z., L. Manczinger, L. Ferenczy, (1997) Transformation of a mycoparasitic Trichoderma harzianum strain with the $\operatorname{argB}$ gene of Aspergillus nidulans. Biotechnol. Techn. 11: 205-208.

Arnaud, M. B., G. C. Cerqueira, D. O. Inglis, (2012). The Aspergillus Genome Database (AspGD): recent developments in comprehensive multispecies curation, comparative genomics and community resources. Nucl. Acids Res. 40: 653-659.

Arseculeratne, S. N., D. N. Atapattu, (2004) The assessment of the viability of the endospores of Rhinosporidium seeberi with MTT (3-[4, 5-dimethyl-2-thiazolyl]-2, 5diphenyl-2H-tetrazolium bromide). Mycol. Res. 108: 1423-1430.

Bakkaiova, J., K. Arata, M. Matsunobu, B. Ono, T. Aoki, D. Lajdova, M. Nebohacova, J. Nosek, I. Miyakawa, L. Tomaska, (2014) A strictly aerobic yeast Yarrowia lipolytica tolerates a loss of a mitochondrial DNA-packaging protein. Eukaryot. Cell. 13: $1143-1157$ 
Bayram, O., G. H. Braus, (2012) Coordination of secondary metabolism and development in fungi: the velvet family of regulatory proteins FEMS Microbiol. Rev. 36:1-24.

Bayram, O., S. Krappmann, M. Ni, (2008) VelB/VeA/LaeA complex coordinates light signal with fungal development and secondary metabolism. Science 320:1504-1506.

Beck, K., N. Acestor, A. Schulfer, A. Anupama, J. Carnes, A. K. Panigrahi, K. Stuart, (2013) Trypanosoma brucei Tb927.2.6100 is an essential protein associated with kinetoplast DNA. Eukaryot. Cell 12: 970-978.

Bok, J. W., N. P., Keller, (2004) LaeA, a regulator of secondary metabolism in Aspergillus spp. Eukaryot. Cell 3: 527-35.

Bok, J. W., D. Noordermeer, S. P. Kale, N. P. Keller, (2006) Secondary metabolic gene cluster silencing in Aspergillus nidulans. Mol. Microbiol. 61: 1636-45.

Borgia, P. T., C. L. Dodge, (1992) Characterization of Aspergillus nidulans mutants deficient in cell wall chitin or glucan. J. Bacteriol.174: 377-383

Bradford, M. M., (1976) A rapid and sensitive method for the quantitation of microgram quantities of protein utilizing the principle of protein-dye binding. Anal. Biochem. 72: $248-254$.

Brewer, L. R., R. Friddle, A. Noy, E. Baldwin, S. S. Martin, M. Corzett, R. Balhorn, R. J. Baskin, (2003) Packaging of single DNA molecules by the yeast mitochondrial protein Abf2p. Biophys. J. 85: 2519-2524.

Bustin, M. (1999). Regulation of DNA-dependent activities by the functional motifs of the mobility-group chromosomal proteins. Mol. Cell. Biol. 19: 5237-5246.

Bustin, M., (2010) High mobility group proteins. Biochim. Biophys. Acta 1799: 1-2.

Bussink, H. J., S. A. Osmani, (1999) A mitogen-activated protein kinase (MPKA) is involved in polarized growth in the filamentous fungus, Aspergillus nidulans. FEMS Microbiol. Lett. 173: 117-125

Butchko, R. A., T. H. Adams, N. P. Keller, (1999) Aspergillus nidulans mutants defective in stc gene cluster regulation. Genetics 153: 715-720. 
Cammack, R., T. Atwood, P. Campbell, H. Parish, A. Smith, F. Vella, J. Stirling, (2006) Oxford dictionary of biochemistry and molecular biology. Oxford University Press

Cano-Dominguez, N., (2008) NADPH oxidases NOX-1 and NOX-2 require the regulatory subunit NOR-1 to control cell differentiation and growth in Neurospora crassa. Eukaryot. Cell 7: 1352-1361.

Carter, W. O., P. K. Narayanan, J. P. Robinson, (1994) Intracellular hydrogen peroxide and superoxide anion detection in endothelial cells. J. Leukoc. Biol. 55: 253-258.

Chiu, D. T. Y., F. H. Stults, A. L. Tappel, (1976) Purification and properties of rat lung soluble glutathione peroxidase. Biochim. Biophys. Acta 445: 558-566.

Claros, M. G., P. Vincens, (1996) Computational method to predict mitochondrially imported proteins and their targeting sequences. Eur. J. Biochem. 241: 779-786.

Costigan, C., Kolodrubetz, D., Snyder, M., (1994) NHP6A and NHP6B, which encode HMG1- like proteins, are candidates for downstream components of the yeast SLT2 mitogen-activated protein kinase pathway. Mol. Cell. Biol. 14: 2391-2403.

Cotty, P. J., D. Bhatnagar, (1994) Variability among atoxigenic Aspergillus flavus strains in ability to prevent aflatoxin contamination and production of aflatoxin biosynthetic pathway enzymes. Appl. Environ. Microbiol. 60(7): 2248-51.

Criscuolo, A., S. Gribaldo, (2010) BMGE (Block Mapping and Gathering with Entropy): a new software for selection of phylogenetic informative regions from multiple sequence alignments. BMC Evol. Biol. 10: 210.

Czaja, W., K. Y. Miller, B. L. Miller, (2011) Complex mechanisms regulate developmental expression of the matA (HMG) mating type gene in homothallic Aspergillus nidulans. Genetics 189: 795-808.

Deceglie, S., C. Lionetti, J. B. Stewart, B. Habermann, M. Roberti, P. Cantatore, P.

L. Polosa, (2014) Characterization of the sea urchin mitochondrial transcription factor A reveals unusual features. Mitochondrion 14: 34-41.

de Souza, F. S., C. Rampazzo Rde, L. Manhaes, M. J. Soares, D. P. Cavalcanti, M. A. Krieger, S. Goldenberg, S. P. Fragoso, (2010) Knockout of the gene encoding the kinetoplast-associated protein 3 (KAP3) in Trypanosoma cruzi: effect on kinetoplast 
organization, cell proliferation and differentiation. Mol. Biochem. Parasitol. 172: 9098.

Dequard-Chablat, M., C. Allandt, (2002) Two copies of mthmg1, encoding a novel mitochondrial HMG-like protein, delay accumulation of mitochondrial DNA deletions in Podospora anserina. Eukaryot. Cell 1: 503-513.

Dereeper, A., V. Guignon, G. Blanc, S. Audic, S. Buffet, F. Chevenet, J. F. Dufayard, S. Guindon, V. Lefort, M. Lescot, J. M. Claverie, O. Gascuel, (2008) Phylogeny.fr: robust phylogenetic analysis for the non-specialist. Nucl. Acids Res. 36: W465- 469.

Diffley, J. F. és B. Stillman, (1991) A close relative of the nuclear, chromosomal highmobility group protein HMG1 in yeast mitochondria. Proc. Natl. Acad. Sci. USA 88: 7864-7868.

Eisendle, M., M. Schrettl, C. Kragl, D. Müller, P. Illmer, H. Haas, (2006) The intracellular siderophore ferricrocin is involved in iron storage, oxidative-stress, germination, and sexual development in Aspergillus nidulans. Eukaryot. Cell 5: 1596-1603

Ekstrand, M. I., D. Galter, (2009) The MitoPark Mouse - an animal model of Parkinson's disease with impaired respiratory chain function in dopamine neurons. Parkinsonism Relat. Disord. 15 Suppl 3: 185-188.

Emanuelsson, O., H. Nielsen, S. Brunak, G. von Heijne, (2000) Predicting subcellular localization of proteins based on their N-terminal amino acid sequence. J. Mol. Biol. 300: 1005-1016.

Emri, T., G. Bartók, A. Szentirmai, (1994) Regulation of specific activity of glucose-6phosphate dehydrogenase and 6-phosphogluconate dehydrogenase in Penicillium chrysogenum. FEMS Microbiol. Lett. 117: 67-70.

Ezaki, B., R. C. Gardner, Y. Ezaki, H. Matsumoto, (2000) Expression of aluminum-induced genes in transgenic Arabidopsis plants can ameliorate aluminum stress and/or oxidative stress. Plant Physiol. 122(3): 657-65.

Ferenczy, L., F. Kevei, M. Szegedi, (1975) Increased fusion frequency of Aspergillus nidulans protoplasts. Experientia 31: 50-52. 
Fiehn, O., (2006) Metabolite Profiling in Arabidopsis. Arabidopsis Protocols 2nd edition. Humana Press, Totowa NJ.

Fillinger, S., M. Chaveroche, P. Dijck, R. Vries, G. Ruijter, J. Thevelein, C. d'Enfert, (2001) Trehalose is required for the acquisition of tolerance to a variety of stresses in the filamentous fungus Aspergillus nidulans. Microbiology 147: 1851-1862

Finn, R. D., A. Bateman, J. Clements, P. Coggill, R.Y. Eberhardt, S.R. Eddy, A. Heger, K. Hetherington, L. Holm, J. Mistry, E.L.L. Sonnhammer, J. Tate, M. Punta, (2014) The Pfam protein families database. Nucl. Acids Res. 42: 222-230

Fleißner, A., P. Dersch, (2010) Expression and export: recombinant protein production systems for Aspergillus. Appl. Microbiol. Biotechnol. 87: 1255-1270.

Fraser, J. A., M. A. Davis, M. J. Hynes, (2002) A gene from Aspergillus nidulans with similarity to URE2 of Saccharomyces cerevisiae encodes a glutathione S-transferase which contributes to heavy metal and xenobiotic resistance. Appl. Environ.

Microbiol. 68: 2802-2808.

Galagan, J. E., (2005) Sequencing of Aspergillus nidulans and comparative analysis with $A$. fumigatus and A. oryzae. Nature 438: 1105-1115.

García, I., M. Mathieu, I. Nikolaev, B. Felenbok, C. Scazzocchio, (2008) Roles of the Aspergillus nidulans homologues of Tup1 and Ssn6 in chromatin structure and cell viability. FEMS Microbiol. Lett. 289: 146-54.

Gille, G., K. Sigler, (1995) Oxidative stress and living cells. Folia Microbiol. 40: 131-152.

Grosschedl, R., K. Giese, J. Pagel, (1994) HMG domain proteins: architectural elements in the assembly of nucleoprotein structures. Trends Genet. 10: 94-100.

Guda, C., (2006) pTARGET: a web server for predicting protein subcellular localization. Nucl. Acids Res. 34: 210-213.

Guda, C., S. Subramaniam, (2005) pTARGET [corrected] a new method for predicting protein subcellular localization in eukaryotes. Bioinformatics 21: 3963-3969.

Guerriero, G., L. Silvestrini, M. Obersriebnig, M. Salerno, D. Pum, J. Strauss, (2013) Sensitivity of Aspergillus nidulans to the cellulose synthase inhibitor dichlobenil: 
insights from wall-related genes' expression and ultrastructural hyphal morphologies. PLoS One 8: e80038

Gugnani H. C., (2003) Ecology and taxonomy of pathogenic Aspergilli. Front. Biosci. 8: 346-357.

Guindon S., J. F. Dufayard, V. Lefort, M. Anisimova, W. Hordijk, O. Gascuel, (2010) New algorithms and methods to estimate maximum-likelihood phylogenies: assessing the performance of PhyML 3.0. Syst. Biol. 59: 307-321.

Hamari, Z., S. Amillis, C. Drevet, A. Apostolaki, C. Vágvölgyi, G. Diallinas, C. Scazzocchio, (2009) Convergent evolution and orphan genes in the Fur4p-like family and characterization of a general nucleoside transporter in Aspergillus nidulans. Mol. Microbiol. 73: 43-57.

Han, K.H., (2009) Molecular genetics of Emericella nidulans sexual development. Mycobiology 37: 171-182

Hedges, S. B., P. Shah, (2003) Comparison of mode estimation methods and application in molecular clock analysis. BMC Bioinform. 4: 31.

Horton, P., K. J. Park, T. Obayashi, N. Fujita, H. Harada, C. J. Adams-Collier, K. Nakai, (2007) WoLF PSORT: protein localization predictor. Nucl. Acids Res. 35: 585-587.

Humphrey, W., A. Dalke, K. Schulten, (1996) VMD: visual molecular dynamics. J. Mol. Graph. $\quad$ 14: 33-38, 27-38.

Jaivel, N., P. Marimuthu, (2010) Optimization of lovastatin production in solid state fermentation by Aspergillus terreus. Int. J. Eng. Sci. 2: 2730-2733.

Karácsony, Z., A. Gácser, C. Vágvölgyi, C. Scazzocchio, Z. Hamari, (2014) A dually located multi-HMG-box protein of Aspergillus nidulans has a crucial role in conidial and ascospore germination. Mol. Microbiol. 94: 383-402.

Karácsony, Z., A. Gácser, C. Vágvölgyi, Z. Hamari, (2015) Further characterization of the role of the mitochondrial high-mobility group box protein in the intracellular redox environment of Aspergillus nidulans. Microbiology 161: 1897-1908. 
Kato, N., W. Brooks, A. M. Calvo, (2003) The expression of sterigmatocystin and penicillin genes in Aspergillus nidulans is controlled by veA, a gene required for sexual development. Eukaryot. Cell 2: 1178-1186.

Katoh, K., D. M. Standley, (2013) MAFFT multiple sequence alignment software version 7: improvements in performance and usability. Mol. Biol. Evol.30: 772-780.

Kaufman, B. A., N. Durisic, J. M. Mativetsky, S. Costantino, M. A. Hancock, P. Grutter, E. A. Shoubridge, (2007) The mitochondrial transcription factor TFAM coordinates the assembly of multiple DNA molecules into nucleoid-like structures. Mol. Biol. Cell 18: $3225-3236$.

Kelkar, H. S., T. W. Skloss, J. F. Haw, N. P. Keller, T. H. Adams, (1997) Aspergillus nidulans stcL encodes a putative cytochrome P-450 monooxygenase required for bisfuran desaturation during aflatoxin/sterigmatocystin biosynthesis. J. Biol. Chem. 272: $1589-94$.

Kevei, F., J. F. Peberdy, (1977) Interspecific hybridization between Aspergillus nidulans and Aspergillus rugulosus by fusion of somatic protoplasts. J. Gen. Microbiol. 102: 255262.

King, B. R., C. Guda, (2007) ngLOC: an n-gram-based Bayesian method for estimating the subcellular proteomes of eukaryotes. Genome Biol. 8: 68 .

Kolodrubetz, D., A. Burgum, (1990) Duplicated NHP6 genes of Saccharomyces cerevisiae encode proteins homologous to bovine high mobility group protein 1. J. Biol. Chem. 265: 3234-3239.

Kosugi, S., M. Hasebe, M. Tomita, H. Yanagawa, (2009) Systematic identification of cell cycle dependent yeast nucleocytoplasmic shuttling proteins by prediction of composite motifs. Proc. Natl. Acad. Sci. USA 106: 10171-10176.

Kucej, M., R. A. Butow, (2007) Evolutionary tinkering with mitochondrial nucleoids. Trends Cell Biol. 17: 586-592.

Laemmli, U. K., (1970) Cleavage of structural proteins during the assembly of the head of bacteriophage T4. Nature 227: 680-685. 
Lara-Ortiz, T., (2003) Reactive oxygen species generated by microbial NADPH oxidase NoxA regulate sexual development in Aspergillus nidulans. Mol. Microbiol.50: 1241-1255.

Larionov, A., A. Krause, W. Miller, (2005) A standard curve based method for relative real time PCR data processing. BMC Bioinform. 6: 62.

Larsson, N. G., J. D. Garman, A. Oldfors, G. S. Barsh, D. A. Clayton, (1996) A single mouse gene encodes the mitochondrial transcription factor $\mathrm{A}$ and a testis-specific nuclear HMG-box protein. Nat. Genet. 13: 296-302.

Larsson, N. G., J. Wang, H. Wilhelmsson, A. Oldfors, P. Rustin, M. Lewandoski, G. S. Barsh, D. A. Clayton, (1998) Mitochondrial transcription factor A is necessary for mtDNA maintenance and embryogenesis in mice. Nat. Genet. 18: 231-236.

Lee, S. A., M. S. Kwak, S. Kim, J. S. Shin, (2014) The role of high mobility group box 1 in innate immunity. Yonsei. Med. J. 55: 1165-1176

Lewinska, A., G. Bartosz, (2008) A role for yeast glutaredoxin genes in selenite-mediated oxidative stress. Fungal Genet. Biol. 45:1182-11877.

Liu, Y., J. W. Leigh, H. Brinkmann, M. T. Cushion, N. Rodriguez-Ezpeleta, H. Philippe, B. F. Lang, (2009) Phylogenomic analyses support the monophyly of Taphrinomycotina, including Schizosaccharomyces fission yeasts. Mol. Biol. Evol. 26: $27-34$.

Liu, Y. J., B. D. Hall, (2004) Body plan evolution of ascomycetes, as inferred from an RNA polymerase II phylogeny. Proc. Natl. Acad. Sci. USA 101: 4507-4512.

Lu, J., R. Kobayashi, S. J. Brill, (1996) Characterization of a high mobility group 1/2 homolog in yeast. J. Biol. Chem. 271: 33678-33685.

Lupas, A., (1996) Prediction and analysis of coiled-coil structures. Methods Enzymol. 266: 513-525.

Lupas, A., M. van Dyke, J. Stock, (1991) Predicting coiled coils from protein sequences. Science 252: 1162-1164. 
MacAlpine, D. M., P. S. Perlman, R. A. Butow, (1998) The high mobility group protein Abf2p influences the level of yeast mitochondrial DNA recombination intermediates in vivo. Proc. Natl. Acad. Sci. USA 95: 6739-6743.

Malarkey, C. S., M. E. Churchill, (2012) The high mobility group box: the ultimate utility player of a cell. Trends Biochem. Sci. 37: 553-562

Maniatis, T., E. F. Fritsch, J. Sambrook, (1982) Molecular cloning: a laboratory manual. Cold Spring Harbor Laboratory, Cold Spring Harbor, N.Y.

Marin, S., A. J. Ramos, G. Cano-Sancho, V. Sanchis, (2013) Mycotoxins: Occurrence, toxicology, and exposure assessment. Food Chem. Toxicol. 60: 218-237

Masse J. E., B. Wong, Y. M. Yen, F. H. T. Allain, R. C. Johnson and J. Feigon, (2002) The S. cerevisiae architectural HMGB protein NHP6A complexed with DNA: DNA and protein conformational changes upon binding. J. Mol. Biol. 323: 263-284

Matsushima, Y., K. Matsumura, S. Ishii, H. Inagaki, T. Suzuki, Y. Matsuda, K. Beck, Y. Kitagawa, (2003) Functional domains of chicken mitochondrial transcription factor A for the maintenance of mitochondrial DNA copy number in lymphoma cell line DT40. J. Biol. Chem. 278: 31149-31158.

May, G. S., (1989) The highly divergent beta-tubulins of Aspergillus nidulans are functionally interchangeable. J. Cell Biol. 109: 2267-2274.

McCulloch, V., G. S. Shadel, (2003) Human mitochondrial transcription factor B1 interacts with the C-terminal activation region of h-mtTFA and stimulates transcription independently of its RNA methyltransferase activity. Mol. Cell. Biol. 23: 5816-5824.

Megraw, T. L., C. B. Chae, (1993) Functional complementarity between the HMG1-like yeast mitochondrial histone HM and the bacterial histone-like protein HU. J. Biol. Chem. 268: 12758-12763.

Menke, J., J. Weber, K. Broz, H. C. Kistler, (2013) Cellular development associated with induced mycotoxin synthesis in the filamentous fungus Fusarium graminearum. PLoS One 8: e63077.

Merz, K., M. Hondele, H. Goetze, K. Gmelch, U. Stoeckl, J. Griesenbeck, (2008) Actively transcribed rRNA genes in $S$. cerevisiae are organized in a specialized chromatin 
associated with the high-mobility group protein Hmo1 and are largely devoid of histone molecules. Genes Devel. 22: 1190-1204.

Miyakawa, I., M. Kanayama, Y. Fujita, H. Sato, (2010) Morphology and protein composition of the mitochondrial nucleoids in yeast cells lacking Abf2p, a high mobility group protein. J. Gen. Appl. Microbiol. 56: 455-464.

Miyakawa, I., A. Okamuro, S. Kinsky, K. Visacka, L. Tomaska, J. Nosek, (2009) Mitochondrial nucleoids from the yeast Candida parapsilosis: expansion of the repertoire of proteins associated with mitochondrial DNA. Microbiology 155: 15581568.

Nayak, T., H. Edgerton-Morgan, T. Horio, Y. Xiong, C. P. De Souza, S. A. Osmani, B. R. Oakley, (2010) Gamma-tubulin regulates the anaphase-promoting complex/cyclosome during interphase. J. Cell Biol. 190: 317-330.

Ngo, H. B., J. T. Kaiser, D. C. Chan, (2011) The mitochondrial transcription and packaging factor Tfam imposes a U-turn on mitochondrial DNA. Nat. Struct. Mol. Biol. 18: 1290-1296.

Nutzmann, H. W., J. Fischer, K. Scherlach, C. Hertweck, A. A. Brakhage, (2013) Distinct amino acids of histone H3 control secondary metabolism in Aspergillus nidulans. Appl. Env. Microbiol. 79: 6102-6109.

Oberley, L. W., D. R. Spitz, (1984) Assay of superoxide dismutase activity in tumor tissue. Methods Enzymol. 105: 457-464.

Pallante, P., R. Sepe, F. Puca, A. Fusco, (2015) High mobility group protein sas tumor markers. Front. Med. 2:15. doi: 10.3389/fmed.2015.00015

Paoletti, M., F. A. Seymour, M. J. C. Alcocer, N. Kaur, A. M. Calvo, D. B. Archer, P. S. Dyer, (2007) Mating type and the genetic basis of self-fertility in the model fungus Aspergillus nidulans. Curr. Biol. 17: 1384-1389.

Parisi, M. A., D. A. Clayton, (1991) Similarity of human mitochondrial transcription factor 1 to high mobility group proteins. Science 252: 965-969 
Parisi, M. A., B. Xu, D. A. Clayton, (1993) A human mitochondrial transcriptional activator can functionally replace a yeast mitochondrial HMG-box protein both in vivo and in vitro. Mol. Cell. Biol. 13: 1951-1961.

Parry, D. A., (1982) Coiled-coils in alpha-helix-containing proteins: analysis of the residue types within the heptad repeat and the use of these data in the prediction of coiledcoils in other proteins. Biosci. Rep. 2: 1017-1024.

Pastukh, V., I. N. Shokolenko, G. L. Wilson, M. F. Alexeyev, (2008) Mutations in the passenger polypeptide can affect its partitioning between mitochondria and cytoplasm: mutations can impair the mitochondrial import of DsRed. Mol. Biol. Rep. 35: $215-223$.

Pinto, M. C., A. M. Mata, J. López-Barea, (1984) Reversible inactivation of Saccharomyces cerevisiae glutathione reductase under reducing conditions. Arch. Biochem. Biophys. 228: 1-12.

Pócsi, I., M. Miskei, Z. Karanyi, T. Emri, P. Ayoubi, T. Pusztahelyi, G. Balla, R. A. Prade, (2005) Comparison of gene expression signatures of diamide, $\mathrm{H}_{2} \mathrm{O}_{2}$ and menadione exposed Aspergillus nidulans cultures - linking genome-wide transcriptional changes to cellular physiology. BMC Genom. 6: 182.

Punt, P. J., R. P. Oliver, M. A. Dingemanse, P. H. Pouwels, C. A. van den Hondel, (1987) Transformation of Aspergillus based on the hygromycin B resistance marker from Escherichia coli. Gene 56: 117-124.

Pusztahelyi, T., E. Klement, E. Szajli, (2011) Comparison of transcriptional and translational changes caused by long-term menadione exposure in Aspergillus nidulans. Fungal Genet. Biol. 48: 92-103.

Pyrzak, W., K. Y. Miller, B. L. Miller, (2008) Mating type protein Mat1-2 from asexual Aspergillus fumigatus drives sexual reproduction in fertile Aspergillus nidulans. Eukaryot. Cell 7: 1029-1040.

Ramón, A., M. I. Muro-Pastor, C. Scazzocchio, R. Gonzalez, (2000) Deletion of the unique gene encoding a typical histone $\mathrm{H} 1$ has no apparent phenotype in Aspergillus nidulans. Mol. Microbiol. 35: 223-33. 
Ray, S., A. Grove, (2009) The yeast high mobility group protein HMO2, a subunit of the chromatin-remodeling complex INO80, binds DNA ends. Nucl. Acids Res. 37: 63896399.

Ray, S., A. Grove, (2012) Interaction of Saccharomyces cerevisiae HMO2 domains with distorted DNA. Biochemistry 51: 1825-1835.

Reeves, R., (2010) Nuclear functions of the HMG proteins. Biochim. Biophys. Acta 1799: 314.

Reyes-Dominguez, Y., F. Narendja, H. Berger, A. Gallmetzer, R. Fernandez-Martin, I. Garcia, C. Scazzocchio, J. Strauss, (2008) Nucleosome positioning and histone H3 acetylation are independent processes in the Aspergillus nidulans prnD-prnB bidirectional promoter. Eukaryot. Cell 7: 656-63.

Reyes-Dominguez, Y., J. W. Bok, H. Berger, E. K. Shwab, A. Basheer, A. Gallmetzer, C. Scazzocchio, N. Keller, J. Strauss, (2010) Heterochromatic marks are associated with the repression of secondary metabolism clusters in Aspergillus nidulans. Mol. Microbiol. 76: 1376-86.

Robellet, X., N. Oestreicher, A. Guitton, C. Velot, (2010) Gene silencing of transgenes inserted in the Aspergillus nidulans alcM and/or alcS loci. Curr. Genet. 56: 341- 348.

Roberts, E., J. Eargle, D. Wright, Z. Luthey-Schulten, (2006) MultiSeq: unifying sequence and structure data for evolutionary analysis. BMC Bioinform. 7: 382.

Roggenkamp, R., H. Sahm, F. Wagner, (1974) Microbial assimilation of methanol induction and function of catalase in Candida boidinii. FEBS Lett. 41: 283-286.

Roy, A., A. Kucukural, Y. Zhang, (2010) I-TASSER: a unified platform for automated protein structure and function prediction. Nat. Protoc. 5: 725-738.

Rubio-Cosials, A., J. F. Sidow, N. Jimenez-Menendez, P. Fernandez-Millan, J. Montoya, H. T. Jacobs, M. Coll, P. Bernado, M. Sola, (2011) Human mitochondrial transcription factor A induces a U-turn structure in the light strand promoter. Nat. Struct. Mol. Biol. 18: 1281-1289.

Rubio-Cosials, A., M. Sola, (2013) U-turn DNA bending by human mitochondrial transcription factor A. Curr. Opin. Struct. Biol. 23: 116-124. 
Russell, R., M. Paterson, N. Lima, (2010) How will climate change affect mycotoxins in food? Food Res. Int. 43: 1902-1914.

Sarikaya Bayram, O., O. Bayram, O. Valerius, (2010) LaeA control of velvet family regulatory proteins for light dependent development and fungal cell-types pecificity. PLoS Genet. 6: e1001226.

Sasaki, N., H. Kuroiwa, C. Nishitani, H. Takano, T. Higashiyama, T. Kobayashi, Y. Shirai, A. Sakai, S. Kawano, K. Murakami-Murofushi, T. Kuroiwa, (2003) Glom is a novel mitochondrial DNA packaging protein in Physarum polycephalum and causes intense chromatin condensation without suppressing DNA functions. Mol. Biol. Cell 14: 4758- 4769.

Sato, I., M. Shimizu, T. Hoshino, N. Takaya, (2009) The glutathione system of Aspergillus nidulans involves a fungus-specific glutathione S-transferase. J. Biol. Chem. 284: 8042-8053.

Schafer, F. Q., G. R. Buettner, (2001) Redox environment of the cell as viewed through the redox state of the glutathione disulfide/glutathione couple. Free Rad. Biol. Med. 30: 1191-1212.

Schluter, A., A. Real-Chicharro, T. Gabaldon, F. Sanchez-Jimenez, A. Pujol, (2010) PeroxisomeDB 2.0: an integrative view of the global peroxisomal metabolome. Nucl. Acids Res. 38: 800-805.

Sewall, T. C., C. W. Mims, W. E. Timberlake, (1990) Conidium differentiation in Aspergillus nidulans wild-type and wet-white (wetA) mutant strains. Dev. Biol. 138: 499-508.

Shimizu, M., S. Masuo, T. Fujita, Y. Doi, Y. Kamimura, N. Takaya, (2012) Hydrolase controls cellular NAD, sirtuin, and secondary metabolites. Mol. Cell Biol. 32: $3743-$ 3755 .

Soukup, A. A., Y. M. Chiang, J. W. Bok, Y. Reyes-Dominguez, B. R. Oakley, C. C. Wang, J. Strauss, N. P. Keller, (2012) Overexpression of the Aspergillus nidulans histone 4 acetyltransferase EsaA increases activation of secondary metabolite production. Mol. Microbiol. 86: 314-330. 
Stillman, D. J., (2010) Nhp6: a small but powerful effector of chromatin structure in Saccharomyces cerevisiae. Biochim. Biophys. Acta 1799: 175-180.

Stinnett, S. M., E. A. Espeso, L. Cobeno, L. Araujo-Bazan, A. M. Calvo, (2007) Aspergillus nidulans VeA subcellular localization is dependent on the importin alpha carrier and on light. Mol. Microbiol. 63: 242-255.

Stott, K., G. S. Tang, K. B. Lee, J. O. Thomas, (2006) Structure of a complex of tandem HMG boxes and DNA. J. Mol. Biol. 360: 90-104.

Stros, M., (2010) HMGB proteins: interactions with DNA and chromatin. Biochim. Biophys. Acta 1799: 101-113.

Stros, M., D. Launholt, K. D. Grasser, (2007) The HMG-box: a versatile protein domain occurring in a wide variety of DNA-binding proteins. Cell. Mol. Life Sci. 64: 25902606.

Sumitani, M., K. Kasashima, J. Matsugi, H. Endo, (2011) Biochemical properties of Caenorhabditis elegans HMG-5, a regulator of mitochondrial DNA. J. Biochem. 149: 581-589.

Tamoi, M., T. Miyazaki, T. Fukamizo, S. Shigeoka, (2005) The Calvin cycle in cyanobacteria is regulated by $\mathrm{CP} 12$ via the $\mathrm{NAD}(\mathrm{H}) / \mathrm{NADP}(\mathrm{H})$ ratio under light/dark conditions. Plant J. 42: 504-513.

Tilburn, J., C. Scazzocchio, G. G. Taylor, J. H. Zabicky-Zissman, R. A. Lackington, R. W. Davies,(1983) Transformation by integration in Aspergillus nidulans. Gene 26: 205-221.

Timberlake, W. E., (1990) Molecular genetics of Aspergillus development. Annu Rev. Genet. 24: 5-36.

Timberlake, W. E., (1993) Translational triggering and feedback fixation in the control of fungal development. Plant Cell 5: 1453-1460.

Vernochet, C., A. Mourier, O. Bezy, Y. Macotela, J. Boucher, M. J. Rardin, D. An, K. Y. Lee, O. R. Ilkayeva, C. M. Zingaretti, B. Emanuelli, G. Smyth, S. Cinti, C. B. Newgard, B. Gibson, W., N. G. Larsson, C. R. Kahn, (2012) Adipose-specific 
deletion of TFAM increases mitochondrial oxidation and protects mice against obesity and insulin resistance. Cell Metab. 16: 765-776.

Visacka, K., J. M. Gerhold, J. Petrovicova, S. Kinsky, P. Joers, J. Nosek, J. Sedman, L. Tomaska, (2009) Novel subfamily of mitochondrial HMG box-containing proteins: functional analysis of Gcf1p from Candida albicans. Microbiology 155: 1226-1240.

Wang, J., V. Pappas-Brown, P. T. Englund, R. E. Jensen, (2014) TbKAP6, a mitochondrial HMG box-containing protein in Trypanosoma brucei, is the first trypanosomatid kinetoplast-associated protein essential for kinetoplast DNA replication and maintenance. Eukaryot. Cell 13: 919-932.

Ward, O.P., W. M. Qin, J. Dhanjoon, J. Ye, A. Singh, (2005) Physiology and biotechnology of Aspergillus. Adv. Appl. Microbiol. 58C: 1-75.

Warholm, M., C. Guthenberg, C. von Bahr, B. Mannervik, (1985) Glutathione transferases from human liver. Methods Enzymol. 113: 499-504.

Wartenberg, D., M. Vodisch, O. Kniemeyer, D. Albrecht-Eckardt, K. Scherlach, R. Winkler, , M. Weide, A. A. Brakhage, (2012) Proteome analysis of the farnesol-induced stress response in Aspergillus nidulans-The role of a putative dehydrin. $J$ Proteomics 75: 4038-4049.

Weisberg, S. H., G. Turian, (1971) Ultrastructure of Aspergillus nidulans conidia and conidial lomasomes. Protoplasma 72: 55-67.

Xiao, L., A. M. Williams, A. Grove, (2010) The C-terminal domain of yeast high mobility group protein HMO1 mediates lateral protein accretion and in-phase DNA bending. Biochemistry 49: 4051-4059.

Xu, C. W., J. C. Hines, M. L. Engel, D. G. Russell, D. S. Ray, (1996) Nucleus-encoded histone H1-like proteins are associated with kinetoplast DNA in the trypanosomatid Crithidia fasciculata. Mol. Cell. Biol. 16: 564-576.

Xu, Y. Z., M. P. Arrieta-Montiel, K. S. Virdi, W. B. de Paula, J. R. Widhalm, G. J. Basset, J. I. Davila, T. E. Elthon, C. G. Elowsky, S. J. Sato, T. E. Clemente, S. A. Mackenzie, (2011) MutS HOMOLOG1 is a nucleoid protein that alters mitochondrial and plastid properties and plant response to high light. Plant Cell 23: 3428-3441. 
$\mathrm{Xu}, \mathrm{D} .$, Y. Zhang, (2012) Ab initio protein structure assembly using continuous structure fragments and optimized knowledge-based force field. Proteins 80: 1715-1735.

Yin, W. B., A.W. Reinke, M. Szilagyi, T. Emri, Y. M. Chiang, A. E. Keating, I. Pocsi, C. C. Wang, N. P. Keller, (2013) bZIP transcription factors affecting secondary metabolism, sexual development and stress responses in Aspergillus nidulans. Microbiology 159: 77-88.

Yoon, Y. G., M. D. Koob, Y. H. Yoo, (2011) Mitochondrial genome-maintaining activity of mouse mitochondrial transcription factor $\mathrm{A}$ and its transcript isoform in Saccharomyces cerevisiae. Gene 484: 52-60.

Yu, J., P. K. Chang, K. C. Ehrlich, J. W. Cary, D. Bhatnagar, T. E. Cleveland, G. A. Payne, J. E. Linz, C. P. Woloshuk, J. W. Bennett, (2004a) Clustered pathway genes in aflatoxin biosynthesis. Appl. Environ. Microbiol. 70: 1253-1262.

Yu, J. H., Z. Hamari, K. H. Han, J. A. Seo, Y. Reyes-Dominguez, C. Scazzocchio, (2004b) Double-joint PCR: a PCR-based molecular tool for gene manipulations in filamentous fungi. Fungal Genet. Biol. 41: 973-981.

Zelenaya-Troitskaya, O., S. M. Newman, K. Okamoto, P. S. Perlman, R. A. Butow, (1998) Functions of the high mobility group protein, Abf2p, in mitochondrial DNA segregation, recombination and copy number in Saccharomyces cerevisiae. Genetics 148: 1763-1776.

Zhang, Y., (2008) I-TASSER server for protein 3D structure prediction. BMC Bioinform. 9: 40 . 


\section{FÜGGELÉKEK}

Függelék I.: A felhasznált A. nidulans törzsek genotípusának leírásakor használt jelölések magyarázata. Feltüntettük az egyes génekről átíródó fehérjék funkcióját, illetve az általunk használt törzsek esetén előforduló mutáns allélok által okozott fenotípust.

\begin{tabular}{|c|c|c|}
\hline Gén neve & Átíródó fehérje funkciója & Fenotípus mutáció esetén \\
\hline$a n A$ & foszfometil-pirimidin-kináz & tiamin auxotrófia \\
\hline $\operatorname{argB}$ & ornitin-karbamoil-transzferáz & arginin auxotrófia \\
\hline biA & dethiobiotin-szintáz & biotin auxotrófia \\
\hline$g f p$ & zöld fluoreszcens fehérje & - \\
\hline$m R F P$ & vörös fluoreszcens fehérje & - \\
\hline$n k u A$ & ATP függő DNS-helikáz & homológ DNS-integráció fokozódása \\
\hline pabaA & para-aminobenzoesav szintáz & para-aminobenzoesav auxotrófia \\
\hline pantoB & ketopentoát-hidroximetil-transzferáz & pantoténsav auxotrófia \\
\hline pyrG & orotidin-5-foszfát-dekarboxiláz & uracil auxotrófia \\
\hline pyroA & piridoxin szintézis & piridoxin auxotrófia \\
\hline riboB & GTP-ciklohidroláz & riboflavin auxotrófia \\
\hline$v e A$ & transzkripciós faktor & ivartalan spóraképzés fény hiányában is \\
\hline$y \boldsymbol{A}$ & para-difenol oxidáz & sérült pigmentszintézis (sárga konídiumok) \\
\hline
\end{tabular}

Függelék II.: Az A. nidulans genomtárban azonosított 7 HMG-box fehérje (AN2885, AN1267, AN10103, AN4734, AN3549, AN1962, AN3667) szekvenciaillesztése ismert élesztő és humán architekturális HMG-box fehérjékkel. Az A. nidulans AN1267 konzervatív C terminális HMG-boxától upstream szekvenciákat nem vontuk be a bemutatott összehasonlításba, mert elővizsgálataink alapján sem HMG-box homológia, sem egyéb ismert Pfam domén homológia nem mutatkozott ezen régióval. Az illesztésben szereplő AN1267 szekvencia csonkolt verzióját truncAN1267-ként tüntettük fel. Az ScNhp6A, ScHMO1, SCHMO2 a Saccharomyces cerevisiae Nhp6A, Hmo1 és Hmo2 fehérjéket jelölik, a HsHMGB1 pedig a Homo sapiens HMGB1 fehérjét jelöli. A HMG-box domén szekvenciaspecifikus/nem szekvenciaspecifikus DNS-kötését meghatározó aminosavat a bedobozolt aminosavak alatt csillaggal jelöltük. Az első szürke dobozos kiemelés a humán HMGB1 kevéssé konzervált első HMG-box doménjét jelöli, mellyel az ScHMO1, ScHMO2 és AN10103 gyenge homológiát mutat. A második szürke dobozos kiemelés a humán HMGB1 erősen konzervált második HMG-box doménjét mutatja, mellyel mindegyik bemutatott fehérje erős homológiát mutatott. Az erősen konzervált aminosavakat világoskék kiemeléssel és kék betűkkel, valamint sárga színű kiemeléssel és piros betükkel mutatjuk. 
(1) 1 10 20 30 40 so 60 70 80 90 ScNhp6. (1)

trunCAN1267 (1) --

HsHMGB1 (1)

ScHMO1 (1)

ScHMO2 (1)

AN10103 (1)

ANN4734 (1)
AN3549 (1)

AN1962 (1) UORRL IBNHPPSP PQSTDGDFASDASQFGDMYPLYGT PBPYAGAGQGHD BSFN RQSSVTINMRYAPTAEYPQNASLHHPVTUPFS PTABYSRQBLRQAQVL

HMG-box domén első, kevéssé konzervált kópia

(103) 103

110 120 150 160 170 180 190

AN2885 (1)

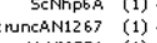

HsHMGB1 (1)
ScHMO1 (1)

ScHMO1 (1)
ScHMO2 (1)

AN 10103 (1) (1) -

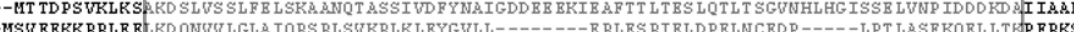

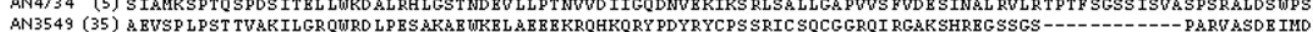
AN1962 (1) -------1 AN3667(103) HNGAR FSTP PADD GFAS GSLD SAPS ARUP SPARROHA SRARVLRS PRQR RRAKNRSS TDSS FVLT BPLSVLTKDHTHV---------- PLKD MESHVNRP

\section{HMG-box domén második, konzervált kópia}

(205) $205 \quad 210$

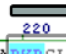
230 240

$250 \begin{array}{llll}220 & 250 & 280 & 280\end{array}$

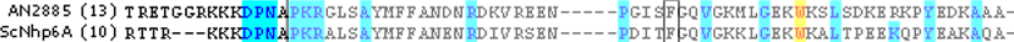

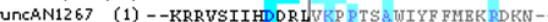

HSHMGB1 (84) B TKK---KFKD PNAPRRP PSARFLFCSBYRPRIKGBH--

SCHMO1 (92) VKAVRRKIB RDPNAPRKRLTVPFAYSAYVROBL RBDRQKAGLPP

SCHMO2 (80) KTKRHKVKE RD PNM RRR PTHAYL L Y CBMNKBRI RONC--

AN10103 (87) GEKKKRKRRADPN

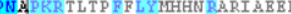

AN $3549(125)$ PNAP RPASMRP..

AN

AN1962 (83) SUTQFCLCQPDPKIP-RPRNARILY RQHYQGUVUAQN---

AN3667(193) IBERLADTAKNDGKIP RPMNS PMLYRSAYANRVKBYF

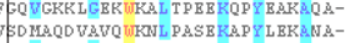

ED WAKKL LEMTNNT AADD KQPY BKKAMK-

F ITQB ISKKWKB L SDNB KEKWKQAYNV-

DVTRD LABG WKNLNNBQD RKP YYKLYY B

TOVSNB GT RRWABM PDSQREVWKKLYAD--

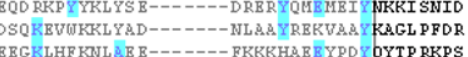

JB ISVI I GKR RA. P PB BGELHF KNL

C

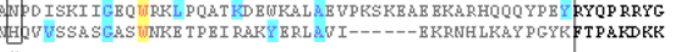

(307) 307 320 330 340 350 360 370 380 390 408 SCN $2885(103)$ (10)

MKLKGNKS--SKD B-----

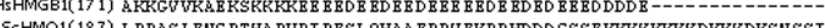

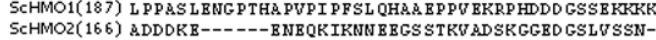

AN10103(178) DDDOKD

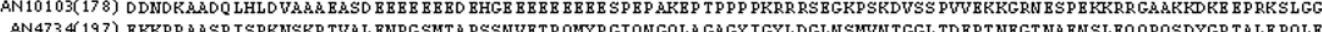

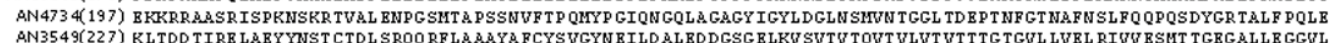
AN3549(227) KLTDD TIRE LABYYNST CTDL SRQORF LAAAYA PCYSVGYN BILD AL EDDGSG BLKVSVTV TQVTVLVTVTT TG TGVL LVBL RIVV BSHT TGBGALLE GGVL

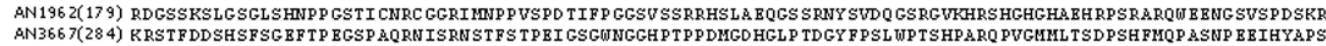

(409) 409 420 430 440 AN2885(107) IUnCAN1267 (94)

IUnCAN1267 (94)

HSHMGB1(216)

ScHMO1(247)

AN $10103(280)$ B SKRSKKKKRKSDVGGDDB-

AN4734(299) BAGPSLGDSSDVGGDDB--

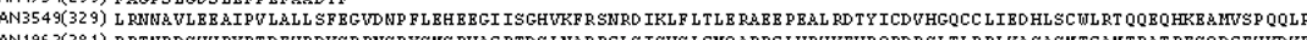
AN3667(386) TML AG L PGA AHHD LLOP OGSP PNSPYSUS PHAGRTDS LNAP RGLS ISHS L GMOAPRG LHPVKRHP QPDP SLTLP PLKA SASM TGAMT TAT PFSQDGFHKDR

(511)

520

530

540

550

560

570

580

$590 \quad 600$ 612 trunCANN1267 (94)

HsHMGB1(216)

ScHMO1(247)

$\mathrm{ScHMO2}(204)$

AN10103(298)

AN $4734(319)$

AN3549(431) s

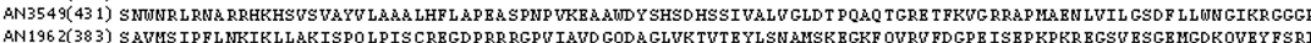

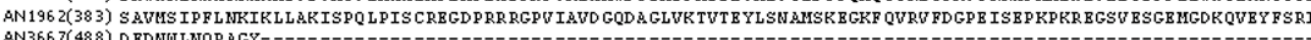

(613) 613

620

630

640

650

660

670

680

690

700 714

ScNhp6A (94)

truncAN1267 (94)

HsHMGB1(216)

ScHMO1(247)

AN $10103(298)$

AN10103(298)

AN3549(533) HSIHG LKGSWCQUCATLNFQUGVTÄWROKBFTKESGL GOPY

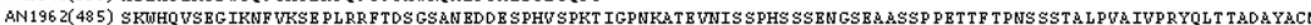

$(715)$

AN2885(107)

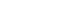

730

, 740

750

760

370

78

790

803

UnCAN1267 (94)

HsHMGB1(216)

ScHMO1(247)

$\mathrm{ScHMO2}(204)$

AN10103(298)

AN 473 4(319)

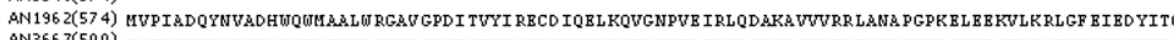


Függelék III.: A kódoló szekvenciában található intronok pozícionálódásának bemutatása Pezizomycotina és Taphrinomycotina HmbB (AN1267) homológ fehérjéken ábrázolva.

\section{: Introninszerció}

\author{
PNEG_02130 \\ Pneji1_1073 \\ Clagr $\overline{9} 5847$ \\ Xanpa_12669 \\ Botci 6194 \\ Amore 18405 \\ Aurpu 73505 \\ Settu-165676 \\ AN1267 \\ PenchWisc1 59309 \\ Talma $194 \overline{6}$ \\ Triru 2624 \\ Neucr 890 \\ Trivi $\bar{G} v 1 \overline{6} 721$ \\ Fusox $1 \overline{8} 7$ \\ Maggr $\overline{1} \_11 \overline{8} 755$ \\ Tubme1 1946 \\ Schpo1_954 \\ Saico1_28314
}

PNEG 02130

Pnejī1 1073

Clagr $\overline{9} 5847$

Xanpa_12669

Botci 6194

Amore_18405

Aurpu_73505

Settu-165676

AN12 $6 \overline{7}$

PenchWisc1 59309

Talma $194 \overline{6}$

Triru 2624

Neucr 890

Trivi $\bar{G} v 1 \overline{6} 721$

Fusox $1 \overline{8} 7$

Maggr $\overline{1} \_11 \overline{8} 755$

Tubme1-1946

Schpo1_954

Saico1_28314

PNEG 02130

Pnejī1_1073

Clagr $\overline{9} 5847$

Xanpa_12669

Botci 6194

Amore 18405

Aurpu_73505

Settu- 165676

AN126 $\overline{7}$

PenchWisc1 59309

Talma_ $194 \overline{6}$

Triru 2624

Neucr 890

Trivi $\bar{G} v 1 \overline{6} 721$

Fusox $1 \overline{8} 7$

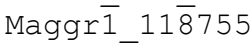

Tubme1_1946

Schpo1_954

Saico1-28314

\begin{abstract}
-------------------MISTNFI I S I GFSTKTLGYRG-------IRAVFKRCLG -----------MLRK VIRKFRNLE IIKRNIMFITRYLGKNQ-------LRKRILPS SQ ----MISQGGRAIVRLPQLKLQC IGVRRAGLSCHNLERAPAFYNALRTRHLFGLARDTGI ----MVFQTHRALARLSRCSFQCLDKPGLAALGFNLTRVALRRPYLGPHEATDTFRPAFQ ----MLSNVGRAAIKRIGG--SNLSTNLLLATVCQLQRVEGQQ-------NVESTLKASS ----MLSSIGRSAIRRVVAGASQPSTTRVFQSVWHLQAAGVSK-------STDNALSRTQ ---MLVLRLPLRLAARPALSHAHVATP IVASS ISATRSYAAKADGTTTTPKKKKAAPISK ----MLAGALCRLAADVPRRSPHDMPQLARHLGRTLLALSAREAP------AARALPCAL -MPLKLIRRGGS I LRNFPGTGSLARPVRVFSPQHRVRCITFVARRSPISVTRGLPCSSST ---MPWLSAARGGFLRTLHRGALSPRTGVSDLQHQLRRVSLTAGSDLARPQVQLLSSTQS MQLIFAARRGRRVLHQVNLQQTTSLSTRVPIAVSNVRRVFRLADTRAAVFSNKTRVSTLN ----MVFKLAQRGQFAFRRFNSRVLYVPSSGLRTEVIASSFAARPS IEGLFRSLSLSNSY ----MFSQIALATARQLRAGTTLVVRTAVAASTSSTTRSAAPSFLRRSGVVFQQRGYALT ----MLS SA GLAAVRRVLTS SGAAAPWRQSTGLAARALVLRLAMPSVRT I S I SASMRSPA ----MLTSVGRAAVRRVQTTRLSASAPSAAQLLCRQSTIKTALPIRSFTVSAWSPSPASG ----MWIRPA TMMLATAMRAGALTSGSRVANVAAYRLVLAARPMATAAANKSTATTTGAA

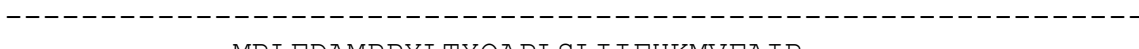
---
\end{abstract}

GMIPINKEYIIQWTNTR-

KKFSIMOFSIASPYNTF----0-0-0

IIPIFRRAYASKPVSRPKAHTGRTTAAARKAPTTSKTKAAKK------PAPR-------TPPLCR-SYAKDAVSRPKAHTGRTATAPRKKASTARSTAPAT------GVESGVVTSNSV TSFLARRLYATATKTTQTETVVEKKPVAKKAPAKKSTTAAKPPVKKST----------VSFEFRRFLAAATKATR--------------ASKTSAESKP-----------------

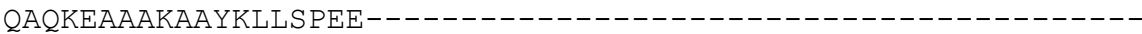
YSHRSYATTATATRATKPTATVKKAVKAAAAEKPPPKKAAAP-----------------

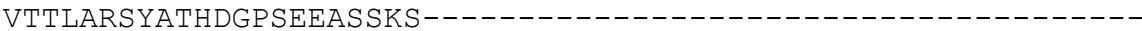

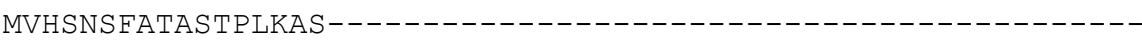
QLGATFQRNQYSTTTTTTSADASKPKPRGRPPKSSEEKPKKK---------------VTTAAKPKTKANKTVQKKK-------------------------------------RAKKTAAESDDTAATATKTNKTRPAAAKSKKSAAEGATG------------------

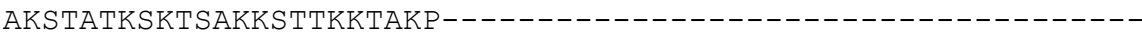
DKKAAKKTTTTTTKKATLTTKSKSK-------------------------------

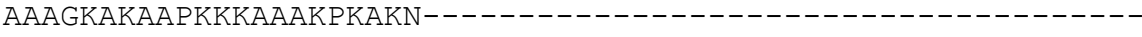

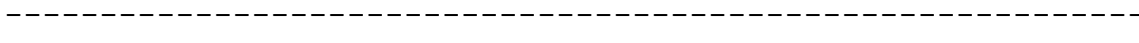
--- - - - - - - - - - - - - - - - - - - - - - - - - - - - - - - - - - - - - - - - - - - - FLKKQCKWKNMS ILSDICLSQIRIFSNSLVNSAVSSNKTSLKA ----TKAAKARPKAKPKAKPKVAKKPKAKPK-----GRKPKALSESQKKAAI IRSLKATA AKKTKSKAKSKPKPKPRTKAKSTKARKKSPKTKATPAKKKKALKPEEKERLLVKELKAKA --KTTTKKTAKPVKKPVKKIKSAKETVAKKRG----PKPKKQLTDAQKLKLKLKELKAIA ----------KTPVKKAKDKAAAKPKTKGR---PKKKKILTPEEKAKREVQKLKALV -------------------------------KAVIDAKRGEEKKKEEVKLLKTKI ------AKKTTAQKPAAKTTKKAEAKKPAAKKARPGRKRKVLTDEEKEKIKIRDLRAKA ----TKSTKTTKTKKTKKKAGKKPAVRKTRKVLTEEQKEARAQRRKAEELKETKRKLKA ------------ETPKAKSSKKAGKPKKKPLSETQKEIERIRKHRAHIRDLKATA ------------AAKKRKPKKKVKKVRKLSEDALEKRRKQRQEQKVKDTIKSLIAES --------------ASKKPTPPPKRGRPGKSDKEKRAEEKKKEARIQAREDLENLKQ ------------AGARAKTPRAKKEAAPKKPKAPKKKAPLTDEQKKKLRIRLLKQRA -----------KAKKPVKKKAIKKKAAVKKPKKTTKKKTLTPEQKERAEIKKLRQMS -----------ATDSKSKSQTKAKPKPKAAAPKPKKAKKEVDPEKAKKLEIRELKKWA ----------TQAKPKAVKKKAVKVSRPPQSPERIEAQKLAAKKKAMREKRIELTRL ----------------------------------------------MKRQKKRMLKE

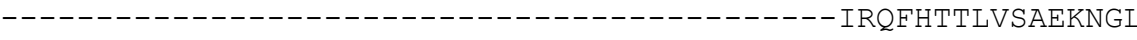


PNEG_02130

Pnejī1 1073

Clagr $\overline{9} 5847$

Xanpa 12669

Botci 6194

Amore 18405

Aurpu_73505 $\varnothing$

Settu 165676

AN1267

PenchWisc1 59309

Talma $194 \overline{6}$

Triru 2624

Neucr 890

TriviḠ $1 \overline{6} 721$

Fusox $1 \overline{8} 7$

Maggr $\overline{1} 11 \overline{8} 755$

Tubme1 1946

Schpo1-954 $\varnothing$

Saico1_28314 $\varnothing$

PNEG 02130

Pnejī1 1073

Clagr_ 95847

Xanpa 12669

Botci_6194

Amore 18405

Aurpu 73505

Settu 165676

AN1267

PenchWisc1 59309

Talma $194 \overline{6}$

Triru 2624

Neucr 890

Trivi $\bar{G} v 1 \overline{6} 721$

Fusox $1 \overline{8} 7$

Maggr $\overline{1} 11 \overline{8} 755$

Tubme1 1946

Schpo1- 954

Saico1 28314

PNEG 02130

Pnejī1 1073

Clagr_95847

Xanpa 12669

Botci_6194

Amore 18405

Aurpu 73505

Settu 165676

AN1267

PenchWisc1 59309

Talma $194 \overline{6}$

Triru 2624

Neucr 890

Trivī̄

Fusox $1 \overline{8} 7 \varnothing$

Maggrí1_118755 $\boldsymbol{\varnothing}$

Tubme1 1946

Schpo1-954

Saicol-28314 $\varnothing$
LP--TPSRMGYSPWIAFIKEKFKQMTG------NGKEIMKQCSS IWKNMSQEER】TYKDI RS--GPSRLGYSPWIAFLKERFKNALG------TPKEILKESSDIWKS LS QEER VVYQDL LV--PPKALPATAWTVFASDAVKDGGAT----IGNRESMAKLSQEFKQFTPERLH HYNH I LS--PPKRLATSAFTVLFVEKQRELRTS----ESAAS ISKECSKI YRS FT PEQRH HYNH I FLKEAPKQI PDTAYSLMFMDLVKKG-------TSVI DAAKQASEKYKSASTAELH RLEQT LS--PPKLKPTSAWKVLFSELSVPG-------QAVSVYAKNVAEKYKS LS PGELH AYNHT LT--PPKYRQLNPWSVYVKENAKSVAG------PVSEIAKVLAQQFKTISSIEKESLDHS LKEPVTQRALSAYNAF IAEAAVGKVDEG----AKQATKIADLSRQFKELTPAQLHHYNHL AALQTPKLLPTLPWVNAMKDKLSEVDKSDN--PS PKEAFSRATELARRATPEER RYVDQ LVSGRPKRL PNNAFAIAMSE I LPHVKGCS----SHKEAFLVAIERAKA IS PQDKH RLQAQ LKKEEPKLRSP IAWNLFVSEKLKGVDR-----EARS SALRD IAAQYRE LPEYQRH ILNQE AALTPPKPLPTSKIAIFSTG-------------KGPLAESVKAFKE ISQFHVI ELAQT LFKEDPKTHRVPAWSAYISEHMKDVLKEGDDIATRRGYFKTLAAQWKELSDAEKA RYQAK LLK-GPTLLPETAWNVYLIDNIRGASG------SVTERAKVLSTS FKNLTETEKH RLTS I LR-DKLAML PATTWVLFT SENKGSLTGTG----GITQQMTELSEKFRQLTESEL DLSRR GLFTEPPKE PEVALRVFLKQWCAKNS I P-----GKGPVFQDMHNAFKALS PAEL ELEET HVLAPPKVPASNPYSTFMSLEG-----------VTVGADAAKKWKALT PEQQdEYAEK QKLI PPRLKTIWNQMLVETKGAGNG---------PERFEMIRQKYKALTADEIQKYKNK AILRSDEGHSDTARVKILDK--------------AKLDTAAGWLEPLPRSRQLRLYRK

SSESRLQASRTYMNWINS LS PKE IMKENHIRNQLRKQGK-----KGITF---IKDPRKPK SLOSKVDATRAYELWVTS LS PKE I SEENRLRNQLRKOGK-----KGISR---IKDPRRPK ANQNKAANEKAYRQWIESHTPKAIYEANLARLNLRRRKL-----KGFFK---IQDHRLVK ANENKASYNSTYRNWILSHS PTQILEANAARVALKKRMK-----SPKTK---LHDERLVK AKENKAVNARNYKNWVQSHTPAE IRTANYARHHIRRLTN-----KSATPR-I IKDDRLVK ANQNKEANEVAFKQWIQSHTPEQIRVANNARMLLKKRTG-----KSYP---LIPDDRIPK VNELNAKSLREFQEWLSNHTPAQIYEANVARARLRKLLA-----STSSKYALIKDDRLVK AQQLNAANKAKLDAWINSHT PEE IRVANRARALLRKKLMGK-QKSAPAYTSKLHDDRQVK AAANKAANEAALKAWVDS HT PLQ I LEANNARRRLAQLQG-------KRRVS I IHDDRLVK AKANYAANTAAYNSWVQSHTPLQIREANSARLTLSRLEN-------KSYPPLKDDRLVT ASKLSKENEAKLKEWVHSYS PLR IKQANAARKLLPKYMAKH-EKS PIIKLSAIRDDRQVK AEKNAETNRHNLEQWIESHT PLE IKNANAARRKLRRILP-----KKSRLYSP IKDDRQVK ADKAHQDGVATRAAWVLTKT PME IEDANYARHALKRLGVT-------SVVHP I PDDRRPK GNSNKIANQESKKKWIQSFP PEVIYTANLARRRLARKTD-------KSKVYLIHDDRLPH AVANRQKNLATYKAWVETHEPARIHLANKTRRRLAFLTG-------KPVKQISDERLPQ AAKNKISNE IAHKAWVQSHTPSE INEANKARHYLARVFKLKSVKGVCLTRGHIKDDRI PS GRNLHALGLQNREKWVKTYHPLEVYKANKARKHLKRLGG-------GKKFDVLKDPRMPK LQEQFDAEKKRFMETLRSFTPTEIDSENRRRSKEAHSTG--------SRYYRLRHPDVPK ARAGIEKYDEEMRAFI DSMT PEELAAENARREAHNLQKI IP---DGPAHQPEAAPVYEGK $: \quad \star \quad: \quad \star *$

RPLSAFLFFCAYARSSPDFIEKY--TEGTTKITEQTKILAKKWALMDDFEKGEFINSSIN RPMT PFLFYCAHARSS PDFVEKY--AGGATKATEQVQALSRKWAAMRDEEKN KFIDQAID GRLNAYSLFLKDRMLSGDMKG-------LKS PEAFRLTAREWKGLSAGERI PYDDAAKQ RPRNAFSRFSVQRHLSRDFAG-------MKLGEAAKLISAEWRAMSENDKH PFLQERDE KVTSSLFLFMKERYQSGEFAG-------LGI PESSKQIVQEYKSMSPEQRI PFEDASLA KARTEHALFTQDRWASGDLKG-------IKFSEASRI LRDEYLALPESERH VYKDRAEA RPISSYLQYHNERLASGDFRG--------IPAPDASKTVATEFKAMSATEKপ KYVDLAAK TVPSAYIFFFTARHASGDFKN-------IKAQDASKLI GNEWKALSDAEKH KYEEERQA PPTSAWI YFFMEKRDKN----------ALVVSDMAQDVAVQWKNLPASEKA PYLEKANA VSRSAYTLYLKERMETEYQGK--------AGVESFPAIGREWLALPQAEKI RYRKLQIE RPVSAFLWF FKERVATGEYRG-------LPVTEISERVKAEWVNTSDSEK LYLTKAEE GPRNAYLLYSLDMHNSGELRH-------LSAKERVAETARSWKNASESEKH KYKSLQEE RLRSAFLFFCMSRQKDALYAG-------KPLPEIAKALSEEWKSMDDAAK@ PYVDNAAV RAGSAFTYYLKEQFSQAGTEK---------VTDAMRT I SERWRS LSP SEKA PYIERAQE RPTGSYSLYLVDNWDKSHAET---------NQAKFKEI GESWKDVNPTEKALYEQRSAD SPLS PYMNFMKLRLKELSHQAPD--N---FRTGVNMTDAATAWKKLSEAERKVYEDMFRA RPTP IGAAFLRDQWNAGTFINPD--GS-KMPAVLALKHSRDLYEKLSAAEK VVYEDQFAA KPSSAFI LFYKELRNNPKLRQELGI PEAISTLVEETQNASKAWKELAEDKK P FIDKSKA KPTTSFILFSKAVRTDAKLSAEYG-IDKHMPGGVGAKLLGEAWRKLSDAEKEPYVKMYAQ 

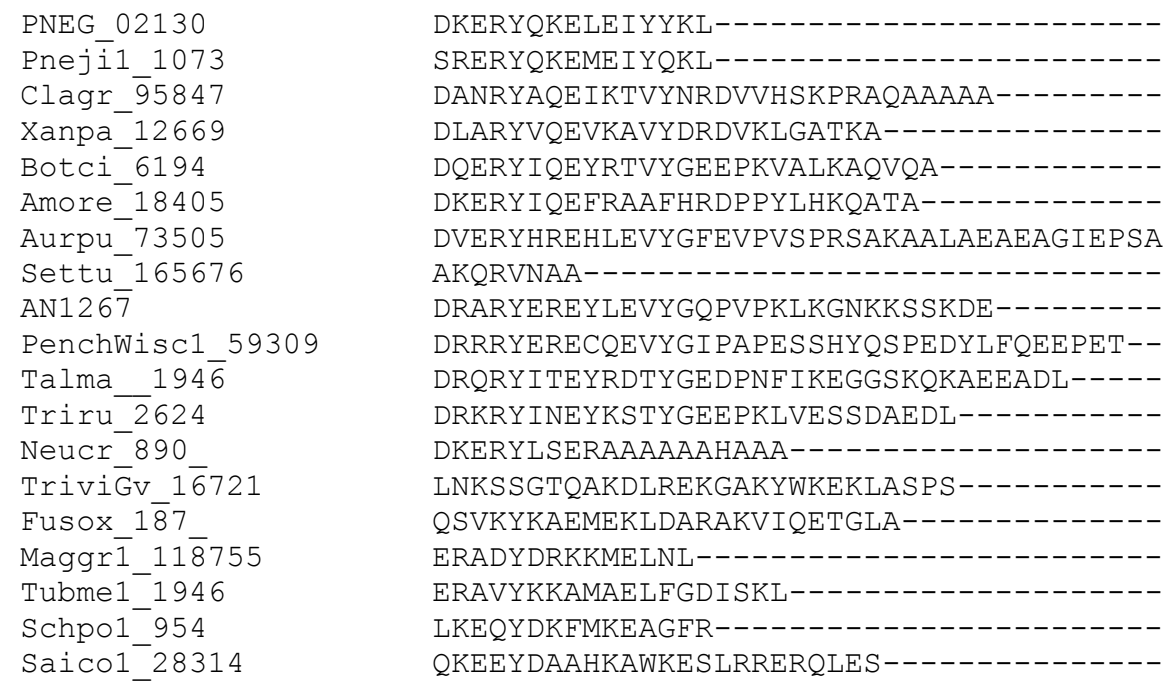

Az illesztéshez felhasznált szekvenciák: Pneumocystis murina PNEG_02130, Pneumocystis jirovecii Pneji1_1073, Cladonia grayi Clagr_95847, Xanthoria parietina Xanpa_12669, Botrytis cinerea Botci_6194, Acremonium recifei Amore_18405, Aureobasidium pullulans Aurpu_73505, Setosphaeria turcica Settu_165676, Penicillium chrisogenum PenchWic1_59309, Talaromyces marneffei Talma_1946, Trichophyton rubrum Triru_2624, Neurospora crassa Neucr_890, Trichoderma virens TriviGv_16721, Fusarium oxysporum Fusox_187, Magnaporthe grisea Maggr1_118755, Tuber melanosporum Tubme1_1946, Schizosaccharomyces pombe Schpo1_954, Saitoella complicata Saico1_28314. A piros vonal az intron inszerciós helyeket jelölik, az áthúzott kör pedig a vonatkozó intron hiányára utal. 